\title{
Urogenital and anal chlamydia trachomatis and human papillomavirus infections
}

Citation for published version (APA):

Smelov, V. (2017). Urogenital and anal chlamydia trachomatis and human papillomavirus infections: epidemiological, diagnostic and public health aspects. [Doctoral Thesis, Maastricht University]. Maastricht University. https://doi.org/10.26481/dis.20171218vs

Document status and date:

Published: 01/01/2017

DOI:

10.26481/dis.20171218vs

Document Version:

Publisher's PDF, also known as Version of record

\section{Please check the document version of this publication:}

- A submitted manuscript is the version of the article upon submission and before peer-review. There can be important differences between the submitted version and the official published version of record.

People interested in the research are advised to contact the author for the final version of the publication, or visit the DOI to the publisher's website.

- The final author version and the galley proof are versions of the publication after peer review.

- The final published version features the final layout of the paper including the volume, issue and page numbers.

Link to publication

\footnotetext{
General rights rights.

- You may freely distribute the URL identifying the publication in the public portal. please follow below link for the End User Agreement:

www.umlib.nl/taverne-license

Take down policy

If you believe that this document breaches copyright please contact us at:

repository@maastrichtuniversity.nl

providing details and we will investigate your claim.
}

Copyright and moral rights for the publications made accessible in the public portal are retained by the authors and/or other copyright owners and it is a condition of accessing publications that users recognise and abide by the legal requirements associated with these

- Users may download and print one copy of any publication from the public portal for the purpose of private study or research.

- You may not further distribute the material or use it for any profit-making activity or commercial gain

If the publication is distributed under the terms of Article $25 \mathrm{fa}$ of the Dutch Copyright Act, indicated by the "Taverne" license above, 


\section{UROGENITAL AND ANAL \\ CHLAMYDIA TRACHOMATIS AND}

HUMAN PAPILLOMAVIRUS INFECTIONS:

EPIDEMIOLOGICAL, DIAGNOSTIC

AND PUBLIC HEALTH ASPECTS 
The research presented in this thesis was conducted at the Maastricht University, VU University Medical Center Amsterdam, Amsterdam Public Health Service (GGD), the North-Western State Medical University named after I.I. Mechnikov (St. Petersburg), the Karolinska University Hospital in Huddinge (Sweden), and the International Agency for Research on Cancer (IARC) in Lyon (France). Furthermore, the research presented in this thesis was supported in part by the European Commission within the Sixth Framework Programme through the EpiGenChlamydia project (contract no. LSHG-CT-2007-037637, see www.EpiGenChlamydia.eu for more details), a United Nations Educational, Scientific and Cultural Organization (UNESCO)-American Society for Microbiology International Travel Award (to V. Smelov, 2006), the European Urological Scholarship Programme (Clinical Fellowship 2007 to V. Smelov) and the Swedish Cancer Society (Scholarship 2011 to V. Smelov). The work was in part undertaken during the tenure of a postdoctoral fellowship from the IARC, partially supported by the European Commission FP7 Marie Curie Actions-People-Cofunding of regional, national, and international programmes (COFUND) (to V. Smelov, 2013). The funders had no role in study design, data collection, and analysis.

Financial support for printing and dissemination of this thesis by the Institute of Public Health Genomics (IPHG) at the Maastricht University is gratefully acknowledged.

(C) Copyright Vitaly Smelov Lyon France 2017

All rights reserved. No part of this thesis may be reproduced or transmitted in any form or by any means, electronic or mechanical, including photocopying, recording, or any information storage or retrieval system without permission from the author, or when appropriate, from the publishers of the publications.

Alle rechten voorbehouden. Niets uit deze uitgave mag worden verveelvoudigd, opgeslagen in een geautomatiseerd gegevensbestand en/of openbaar gemaakt in enige vorm of op enige wijze, hetzij elektronisch, mechanisch, door fotokopieën, opnamen of op enige andere manier zonder voorafgaande schriftelijke toestemming van de uitgever.

Cover design: Mark Smelov

Layout: Vitaly Smelov

Printing: GVO drukkers \& vormgevers BV, Ede, the Netherlands

ISBN: 978-94-6332-282-9 


\title{
UROGENITAL AND ANAL \\ CHLAMYDIA TRACHOMATIS AND \\ HUMAN PAPILLOMAVIRUS INFECTIONS: \\ EPIDEMIOLOGICAL, DIAGNOSTIC AND PUBLIC HEALTH ASPECTS
}

\author{
Proefschrift
}

Ter verkrijging van de graad van doctor aan de Universiteit Maastricht, op gezag van de Rector Magnificus, prof. dr.mr. R.M. Letschert, volgens het besluit van het College van Decanen

in het openbaar te verdedigen

op 18 december 2017 om 11:30 uur

door

Vitaly Smelov

Geboren op 2 september 1970 te Neustrelitz 
Promoters

Prof. dr. S.A. Morré

Prof. dr. H.J.C. de Vries, University of Amsterdam, Amsterdam, the Netherlands

Co-promotor:

Dr. Sander Ouburg, VU University, Amsterdam, the Netherlands

Beoordelingscommissie:

Prof. dr. C.J.P.A. Hoebe (voorzitter)

Prof. dr. J. van Bergen, Academisch Medisch Centrum Amsterdam

Prof. dr. J.F.C. Glatz

Dr. D.A.M. Heideman, VU Medisch Centrum, Amsterdam

Prof. dr. P. Savelkoul 
To my mum, for her believe in me as a doctor from the very first look, continuous support across the globe, and constant love

Моей маме за её веру в меня как врача с самого первого взгляда, непрерывную поддержку в любой точке мира и любовь 


\section{Table of contents}

Chapter 1. Introduction

Aims and Outline

Chapter 2. Prevalence of genital Chlamydia trachomatis infections in Russia: systematic literature review and multicenter study. Pathog Dis. 2017 Sep 29;75(7).

Chapter 3. Chlamydia trachomatis serovar distributions in Russian men and women: a comparison with Dutch serovar distributions. Drugs Today (Barc). 2009 Nov;45 Suppl B:33-8.

Chapter 4. Chlamydia trachomatis strain types have diversified regionally and globally with evidence for recombination across geographic divides. Front in Microbiol, in press

Chapter 5. Delayed microbial cure of lymphogranuloma venereum proctitis with doxycycline treatment.

Clin Infect Dis. 2009 Mar 1;48(5):e53-6.

Part II. HPV infection

Chapter 6. Expressed prostate secretions in the study of human papillomavirus epidemiology in the male. PLoS ONE 2013 8;6 e66630.

Chapter 7. Prevalence of cutaneous beta and gamma human papillomaviruses in the anal canal of men who have sex with women. 
Chapter 8. Determinants of presence of human papillomaviruses in the anal canal of men.

Submitted

Chapter 9. General discussion.

Summary

199

Nederlandse samenvatting

205

Краткое содержание на русском языке

211

Résumé fransais

Valorisation

225

Dankwoord

235

List of publications

241

About the author 


\section{List of abbreviations}

\begin{tabular}{|c|c|}
\hline $95 \% \mathrm{CI}$ & $95 \%$ confidence interval \\
\hline AIDS & acquired immune deficiency syndrome \\
\hline ART & antiretroviral therapy \\
\hline ASM & American Society for Microbiology \\
\hline CDC & United States Centers for Disease Control Prevention \\
\hline CDs & constant domains \\
\hline CE-IVD & Conformité Européene in vitro diagnostics mark \\
\hline $\mathrm{Ct} / \mathrm{CT}$ & Chlamydia trachomatis \\
\hline COFUND & cofunding of regional, national, and international programmes \\
\hline DEIA & DNA enzyme immunoassay \\
\hline DRE & digital rectal examination \\
\hline DV & dermatovenereology \\
\hline DNA & desoxyribonucleic acid \\
\hline EAU & European Association of Urology \\
\hline ECDC & European Centre for Disease Prevention and Control \\
\hline EPS & expressed prostate secretion \\
\hline EU/EEA & European Union/European Economic Area \\
\hline EUSP & European Urological Scholarship programme \\
\hline FDA & United States Food and Drug Administration \\
\hline GGD & Geneeskundige en Gezondheidsdienst \\
\hline HAART & highly-active antiretroviral therapy \\
\hline HIV & human immunodeficiency virus \\
\hline HR-HPV & high-risk human papillomavirus \\
\hline HPV & human papillomavirus \\
\hline HSV & herpes simplex virus \\
\hline HSIL & high grade squamous intraepithelial lesion \\
\hline IARC & International Agency for Research on Cancer \\
\hline IDU & injecting drug users \\
\hline VF & in vitro fertilization \\
\hline
\end{tabular}




\begin{tabular}{|c|c|}
\hline LGV & lymphogranuloma venereum \\
\hline LR-HPV & low-risk human papillomavirus \\
\hline MGP & modified general primer system \\
\hline MLST & multi-locus sequence typing \\
\hline \multicolumn{2}{|c|}{ MOMP major outer membrane protein } \\
\hline MSM & men who have sex with men \\
\hline MSW & men who have sex with women \\
\hline NA & not available \\
\hline NAAT & nucleic acid amplification test \\
\hline ompA & gene that encodes the major outer membrane protein \\
\hline OR & odds ratio \\
\hline PCR & polymerase chain reaction \\
\hline PID & pelvic inflammatory disease \\
\hline RAMS & Russian Academy of Medical Sciences \\
\hline RHA & reverse hybridization assay \\
\hline RNA & ribonucleic acid \\
\hline SLV & single locus variants \\
\hline SNP & single-nucleotide polymorphism \\
\hline $\begin{array}{l}\text { SPbMAPS } \\
\text { ST }\end{array}$ & $\begin{array}{l}\text { St. Petersburg Medical Academy for Postgraduate Studies } \\
\text { sequence type }\end{array}$ \\
\hline STI & sexual transmitted infection \\
\hline STD & sexually transmitted disease \\
\hline swCT & Swedish variant of C. trachomatis \\
\hline TS-MPG & type-specific multiplex genotyping \\
\hline VDs & variable domains \\
\hline VU & Vrije Universiteit \\
\hline VUMC & VU University Medical Center \\
\hline UNAIDS & Joint United Nations Programme on HIV/AIDS \\
\hline UNESCO & United Nations Educational, Scientific and Cultural Organization \\
\hline \multicolumn{2}{|c|}{ USAID United States Agency for International Development } \\
\hline WGS & whole genome sequencing \\
\hline WHO & World Health Organization \\
\hline
\end{tabular}





\section{Chapter 1}

\section{Introduction}




\section{Introduction to the thesis}

Sexually transmitted infections (STIs) are a major health problem, causing serious morbidity and mortality, and having a profound impact on sexual and reproductive health. According to the World Health Organization (WHO), every day more than 1 million STIs are acquired worldwide (1), although estimates of the global prevalence and incidence of STIs are limited by quantity and quality of data available from the different regions of the world (2-6), including the Russian Federation. Of more than 30 different pathogens transmitted through vaginal, anal or oral sexual contacts, Chlamydia trachomatis $(\mathrm{Ct})$ and human papillomavirus (HPV) are the most common bacterial and viral STIs, respectively (1), and the main focus of this thesis.

\section{Contents of this chapter}

1. Burden of sexually transmitted C. trachomatis and HPV infections

1.1. Global prevalence and incidence of $C$. trachomatis

1.2. Global prevalence and incidence of HPV

1.3. STIs in Russia, with the main focus on C. trachomatis and HPV

1.3.1. STI services in Russia

1.3.2. Burden of curable STIs in Russia

1.3.3. Burden of HIV in Russia

1.3.4. Prevalence and incidence of genital C. trachomatis in Russia

1.3.5. Prevalence and incidence of HPV in Russia

1.3.6. STIs among MSM in Russia

1.4. STIs in the Netherlands

1.4.1. STI services and current trends in the Netherlands

1.4.2. Prevalence and incidence of $C$. trachomatis in the Netherlands

1.4.3. Prevalence and incidence of HPV in the Netherlands

2. C. trachomatis: microbiological characteristics, diagnostic and clinical aspects

3. HPVs: microbiological characteristics, diagnostic and clinical aspects

4. Aims and outline of this thesis

1.1. Aims

1.2. Outline 


\section{Burden of sexually transmitted C. trachomatis and HPV infections}

\subsection{Global prevalence and incidence of $C$. trachomatis}

Chlamydia is presently the leading cause of preventable blindness and the most prevalent bacterial STIs worldwide (7), with annual estimates of over 250 million trachoma cases and 131 million new STI cases among adults aged 15-49 years (1). In fact, Ct is among four curable STIs, for which the WHO has produced estimates of the global and regional prevalence approximately every 5 years since 1995, using different methods. Applying these prevalence rates collected between 2005 and 2012 to 2012 population, the estimated number of prevalent cases of Ct within 10 WHO regions was 76,054,000 in women, 51,307,000 in men and 127,361,000 in total, respectively (6).

The Ct prevalence and incidence estimates varied by region and sex $(4,5)$. In 2012, the estimated global prevalence of chlamydia within 10 WHO regions was $4.2 \%$ among women and 2.7\% among men (6). Among women, the highest prevalence of Ct was observed in the Region of Americas (7.6\% in total) and the Western Pacific region (6.2\%), while the lowest was observed in Southeast Asia (1.8\%) and Europe (2.2\%). Among men, the highest prevalence of $\mathrm{Ct}$ was observed in the Western Pacific region (5.2\%) and the Eastern Mediterranean (2.7\%), and the lowest was observed in Southeast Asia (1.3\%) and Europe $(1.5 \%)$, respectively $(6)$. The estimated $(4,5)$ global of chlamydia incidence in 2012 was 38/1,000 among women and 33/1,000 among men (6). Among women, the highest incidence of $\mathrm{Ct}$ in women was present in the Americas $(72 / 1,000)$ and the Western Pacific region (56/1,000), while the lowest was observed in Southeast Asia $(15: 1,000)$ and Europe $(22 / 1,000)$. Among men, the highest incidence of Ct was in the Western Pacific region (64/1,000) and the Eastern Mediterranean (33/1,000), and the lowest was observed in Southeast Asia (13/1,000) and Europe (20/1,000), respectively (6).

Notably, the comparison of the prevalence of Ct infections in different parts of the world remains difficult due to the variety of surveillance methods used (i.e., passive vs. report-based surveillance systems) and the lack of reliable information from many world areas (8). The incidence rate of chlamydia in the United States was 479 cases per 100,000 population in 2015 (9). The overall notification rate from 20 European countries (parties of the EU/EEA, the European Union/European Economic Area) with comprehensive 
surveillance systems on Ct infections was 187/100,000 in 2014 (10). The true incidence of chlamydia is likely to be considerably higher and, moreover, there is a current tendency for its further increase (9-11). As there is currently no Ct vaccine and the infection can be treated with antibiotics, further studies on Ct epidemiology and transmission routes as well as optimal early detection and reliable diagnosis remain of high public health importance.

\subsection{Global prevalence and incidence of HPV}

Reliable figures on HPV prevalence and incidence are difficult to obtain. HPV is the most common STI as nearly all sexually active people will get HPV soon after the onset of sexual activity or at some time in their life (12). In the United States, the numbers of annual prevalent and incident HPV infections are 79 million and 14.1 million, respectively (13). Worldwide, the estimated prevalence of HPV infection in women without cervical abnormalities is $10-12 \%$, found highest in women younger than 35 years of age and decreasing in women of older age $(14,15)$. In 2012, the estimated highest HPV rates were in sub-Saharan Africa (24\%), Eastern Europe (21\%) and Latin America (16\%) (15). More than 290 million women have cervical HPV infection at any point in time (16). Prevalence patterns in men and women are different. Transmission patterns differ by gender as well, with female-to-male transmission appeared more common than male-to-female transmission (17). Because of variability in anatomic sites sampled, in devices used to sample, and in laboratory methods for analyses of samples, there is tremendous variability in HPV prevalence estimates in male (18). It is believed that prevalence of HPV in male genitals are around $50 \%$, with prevalence rates appearing to remain steady through all age groups (19).

The prevalence of HPV increases with severity of the lesions (20), ranging from normalcy to different stages of precancerous lesions and invasive cancer. WHO/International Agency for Research on Cancer has classified HPV as a causal agent for anogenital cancers (21). Annually, there are globally 610,000 new cancers attributable to HPV infection (22), which is a major case of infection-related cancers worldwide (23).

Anogenital warts (AGWs) represent a sexually transmitted benign condition caused by HPV infection. Again, reliable surveillance figures are difficult to obtain but data from developed countries indicate an annual prevalence ranged from $0.15 \%$ to $0.2 \%$, with a peak occurring before 24 years of age in females and between 25 and 29 years of age 
among males, with new median AGWs incidence rates among males and females as $137 / 100,000$ and 120.5/100,000 per annum, respectively $(15,24)$.

Although some of HPV variability in men is due to differences in populations, much of such variability is likely due to incomplete anogenital sampling of men (25). In fact, most of the studies on genital HPV infections have been focused on the detection of HPV in the cervix in women or in the anal canal in men who have sex with men (MSM). Relatively little, however, remained known about the prevalence and spectrum of the HPVs in the male anogenital area, in particular among non-MSM populations. Such studies of the epidemiology of HPV infection in the male are essential for understanding HPV natural history and transmission dynamics and optimizing the HPV prevention. This thesis will amongst others focus on the prevalence of genital and anal HPVs in male populations.

\subsection{STIs in Russia, with the main focus on Chlamydia trachomatis and HPV}

\subsubsection{STI services in Russia}

Russia has had a well-developed state system for the surveillance and control of STIs since World War II (26). Historically, the system of STI control in the country was centred around clinical dermatovenereology (DV) services controlled $(27,28)$ by the Ministry of Health, and in the regions by the Divisions of Health Care. In the post-Soviet period the old DV structures have largely survived but with major changes (29). The previously centralized model was changed into a mixed configuration, with private and state financing. Currently, services for STI testing and treatment are provided at state-owned DV dispensaries (i.e. separate health care units that also often contain specialized DV hospitals) and DV services incorporated in the independent health care systems of the military, police, railway and penal organizations, which can also serve the civil population (e.g. the families of the employees), as well as in a number of parallel clinics or "cabinets" in a hospital or outpatient clinic, administrated by federal institutions, universities and research institutes, or privately owned organizations, where a specialist in DV or/and clinical management of the urogenital tract disorders (gynaecologist, urologist, etc.) is stationed. The exact number of the different providers of DV services remains unknown (30). 
State-owned DV services provide free diagnosis, treatment, and partner notification. In alternative services people have to pay (27). The commercial clinics operate on a fee for service basis in which each item is costed and charged directly to the patient. Which diagnostic tests are performed, and which treatment is prescribed are determined to a large extent by the patient's ability or willingness to pay. This leads to wide variation in the quality of the clinical service received (29).

STIs are monitored through mandatory universal notification by physicians of newly identified cases. Notification reports include information about the sex and age of the patient and are performed on a monthly basis. The following curable STIs must be reported: syphilis, gonorrhoea, trichomoniasis, urogenital $\mathrm{Ct}$, genital herpes and anogenital warts (31). Although compulsory, reporting is mostly done by public DV institutions and it is not complete due to self-treatment and treatment by private practitioners, who often do not report cases $(29,32)$.

\subsubsection{Burden of curable STIs in Russia}

STIs continue to be a serious health problem in the Russian Federation (Russia).

The collapse of the Soviet Union, followed by an abrupt free-market transition, eliminated most social-safety mechanisms for millions of people, resulting in the sharpest rise in extreme poverty increased from 2 million to 17 million between 1990 and 1993, while those living below US $\$ 2$ a day also shot up from 8 million in 1987 to 111 million in 1999 in post-Soviet countries (33). The socio-political and economic changes in Russia foreshadowed increased mobility, heavy alcohol consumption, exponential increases in injection drug use and the growing commercial sex industry (34-38). Major economic transitions followed by steep declines in health expenditures and life expectancy $(35,39)$. During the initial period of reorganisation of the healthcare systems questions concerning sexual health were mostly ignored (32). All together fuelled the spread of STIs in the country. For instance, the rate of syphilis showed increased to $265 / 100,000$ in 1997 , a 63 fold increase since 1993. The level of gonorrhoea increased from 1991 to the reported 1993 rate of 230.9/100,000. However, this data did not reflect the actual situation because of under-reporting (26).

The incidence of most STIs started declined from 1994. The analyses of the data on the rates of STIs obtained from the state statistical forms during 1997-2009 shown the tendency to decrease for the majority of STIs in Russia $(40,41)$. The incidence of syphilis 
and gonorrhoea were 79.2 and 79.0/100,000 in 2005 (42) and 58.3 and 48.1/100,000 in 2009, respectively (41).

\subsubsection{Burden of HIV in Russia}

The country has one of the most rapidly growing HIV epidemics globally, with the highest in the WHO European Region rate (67.0/100.000; 64\% of all cases) that is growing by 10$15 \%$ each year (43). The number of people officially registered as living with HIV/AIDS in the Russian Federation has increased significantly from 3.6 thousands in 1997 to 327.9 thousands in 2005 and 907.6 thousands cases reported in 2014, respectively $(44,45)$. Originally driven by male injecting drug users (IDU), the epidemic has been increasing due to heterosexual transmission (40-44\% newly infected) $(26,43,44,46)$. There is a clear association between bacterial and viral STIs and the risk of HIV infection at both individual and population levels (47). Studies on STIs other than HIV could decline in the incidence of HIV.

\subsubsection{Prevalence and incidence of genital Chlamydia trachomatis in} Russia

Genital chlamydia is a notifiable disease since 1993 (27). The reported Ct incidence for Russia in 1993 was 36.8/100,000 but showed a 3-fold increase by 1997 (48), which was followed by a subsequent slow decline since 2000 (Fig. 1) $(40,41,48)$. Currently, Ct is the most common bacterial STI in Russia, with the prevalence and incidence estimates varies by region. An unfavourable situation remains in a number of territories of the Russian Federation, especially in the North West (includes St. Petersburg), the Far East, and the Urals Federal Districts (40,41). Reliable figures regarding incidence and prevalence of Ct infections across different populations remained highly limited. Primarily this is the result of suboptimal diagnostics $(30,32)$, case reporting and surveillance systems (49), the lack of compulsory partner notification and tracing (32) and common in Russian society selfmedication practices due to the ongoing non-prescription access to antimicrobials and popular self-prescribing (50). No Ct studies have been performed among established $(51,52)$ high-risk populations (MSM, female sex workers, etc.). This thesis will study the prevalence of genital Ct in the Russian populations. 


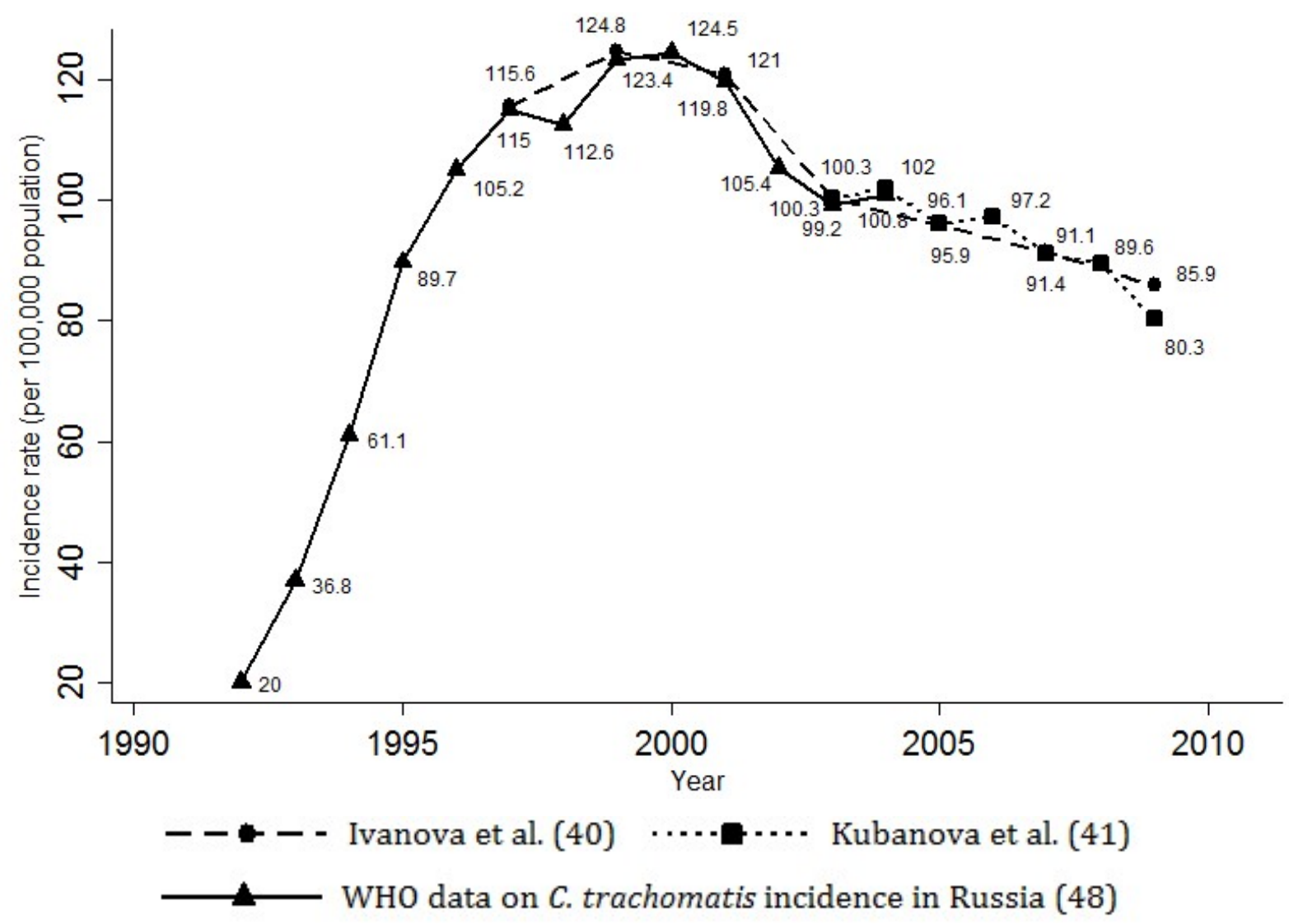

Figure 1. Data on the incidence of C. trachomatis infections per year in the Russian Federation (per 100,000 population) (Adapted from: $(40,41,48)$ ).

\subsubsection{Prevalence and incidence of HPV in Russia}

Only data on the cervical prevalence of HPV types 16 and 18 are available in the Russian Federation (53). Prevalence of the most common HPV types in women with normal cytology, low-grade and high-grade cervical lesions, and cervical cancer are 9.4\%, 35.1\%, $56.0 \%$ and $73.8 \%$, respectively (53).

In addition, caused by lasting HPV infections external anogenital warts in both men and women are among reportable STIs in Russia (31). Obtained data indicate that the virus infections in the country keep the tendency to grow (Fig. 2) $(40,41,54)$.

At the time of the studies presented in the thesis, no data on prevalence or incidence of HPV infection among men were available. Studies of the epidemiology of HPV infection in the male are essential for better understanding HPV natural history, transmission dynamics and optimal prevention strategies. This thesis will study the distribution of HPV types in genital and anal samples obtained in Russian male populations. 


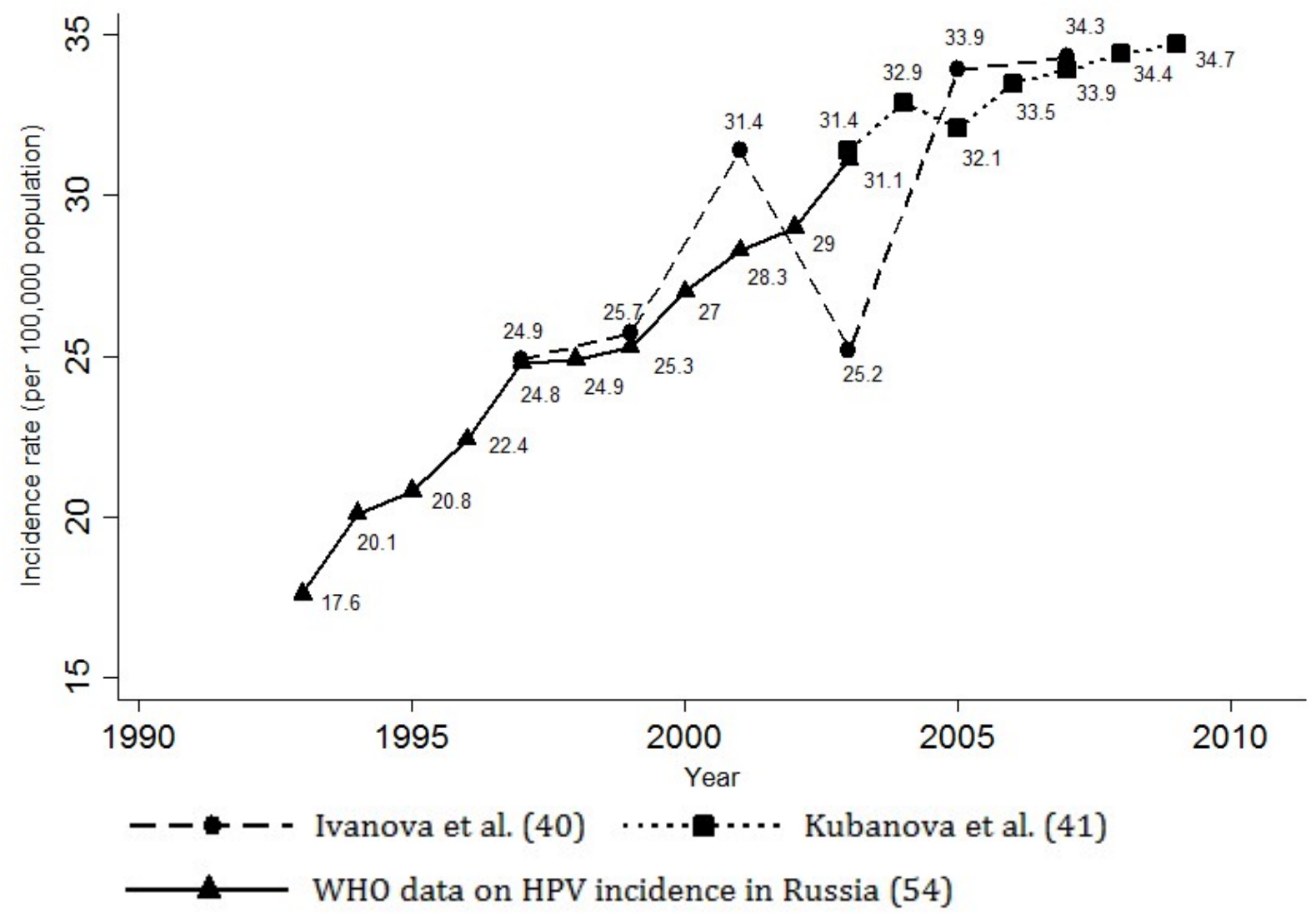

Figure 2. Data on the number of new human papillomavirus (HPV) infections per year and incidence per 100,000 population in the Russian Federation (Adapted from: $(40,41,54))$.

\subsubsection{STIs among MSM in Russia}

Prevalence of lifetime male same-sex sexual behaviour in Eurasian countries varies between 6-27\% (56). Estimated proportion of MSM population in Russia is 2-5\% (57), however conducting studies among MSMs in Russia is complicated, as homosexuality remains a stigmatized topic (58). This may explain the limited number of studies on STIs among MSM and the lack of studies on anal HPV infections in men who have sex with women (MSW). Available data on the prevalence of STIs among Russian MSM is limited to HIV. MSM continue to have disproportionately high burdens of HIV infection in countries of low, middle, and high income countries (59). The Russian Federal AIDS Centre reported that up to $1.5 \%$ of newly HIV transmission is associated with male-to-male sexual intercourse between men $(60,61)$, however the prevalence of HIV among Russian MSMs keeps increasing and currently is about $10 \%(61,62)$. In fact, Russia faces two 
independent HIV epidemics with little overlap between the IDU and MSM highest at-risk populations, which requires different HIV prevention approaches (63).

HIV prevention strategies in the country would benefit from the studies on STIs addressing male populations, including high-risk MSM populations. Extra-genital STIs infections are often asymptomatic and can found in the absence of reported risk behaviours, such as receptive anal and oral intercourse (64). Rectal Ct infection may play a biologically mediated causal role in HIV acquisition (65) and often detected in MSM through routine screening (66). HIV acquisition is associated with presence of HPV infection (67). HIV infection is one of the strongest risk factors for anal cancer (21). Anal HPV prevalence is higher among MSM than MSW (68), and nearly universal among HIVinfected MSM (69).

The thesis will continue with the research on STIs among these male populations.

\subsection{STIs in the Netherlands}

\subsubsection{STI services and current trends in the Netherlands}

In the Netherlands, standard STI testing includes Ct, gonorrhoea and syphilis, HIV testing is performed unless the client refuses it, and testing for hepatitis B virus, hepatitis $\mathrm{C}$ virus, genital herpes and Trichomonas vaginalis are performed if deemed necessary (70). STI care is primarily provided by general practitioners (around 63\% (71)) and specialized STI centers (e.g. Public Health Service). Costs of general practice consultations are covered by the national health insurance. In addition, STI clinics offer free STI testing to high-risk groups and provide care and treatment if an STI is diagnosed.

STIs continue to be a health problem in the Netherlands, although some success in the control of STIs can be noticed. The overall number of newly diagnosed HIV diagnoses continues to decrease, with MSM accounted for nearly $90 \%$ of this group, although the percentage of new HIV diagnoses in MSM has also decreased from 3\% in 2008 to 1.1\% in 2014 (72,73). Syphilis is rare and mainly diagnosed among MSM, accounted for 93\% of new cases (73). The positivity rates for gonorrhoea were stabilising but increased slightly from $2.7 \%$ in 2010 to 3.6\% in 2016, with four times more common in MSM than in women and heterosexual men $(72,73)$. However, the number of people who get tested at a Dutch STI clinic or by general practitioners continues to increase substantially in recent years, with this trend is also notable for $\mathrm{Ct}$, which remains the most frequently diagnosed STI (72-74). Among STI clinic attendees who are positively diagnosed with an STI are mainly 
people who have been warned of possible STI exposure by their (former) partner and known HIV-positive MSM (73).

\subsubsection{Prevalence and incidence of Chlamydia trachomatis in the} Netherlands

The estimated reporting rate of $\mathrm{Ct}$ is 174/100,000 (186 and 162/100,000 in women and in men, respectively) (74). The estimated prevalence of $\mathrm{Ct}$ is about 1.8-2.0\% (in a national representative sample of 21,000 people, $2.5 \%$ (CI: 2.0-3.0) in women and $1.5 \%$ (1.1-1.8) in men, respectively). Chlamydia infection is primarily diagnosed in women and in heterosexual men (in particular among inhabitants of Surinam or Dutch Caribbean) below 25 years of age, and increases with level of urbanisation (51,75-77). Although MSM have a higher percentage of positive STI tests compared with heterosexuals, the percentage of MSM diagnosed with $\mathrm{Ct}$ has remained stable for years at around 10\% (73).

The resurgence of LGV in the industrialized countries was first revealed in 2003 in the Netherlands (78), where LGV cases have been detected among MSM only (79).

\subsubsection{Prevalence and incidence of HPV in the Netherlands}

HPV infection is common in the Netherlands. In women, the prevalence of any HPV type was found $19 \%$ in a population-based study (80), 54\% in a Ct screening intervention study (81), and 73\% in a study among attendees of STI clinics (82). Overall, multiple HPV infections were detected in $26 \%$ of the women (83). Among sexually active young participated in a Dutch Ct screening implementation program, the HPV incidence (45\%) and persistence (34\%) were high (81). In men, data on HPV prevalence is available only among men from special male subgroups but not general population, varying between the sampled anatomical sites (84). Overall genital HPV prevalence varied from $25 \%$ in men visiting a department of dermatology for non-STI complaints (85) to 54\% among heterosexual males attending Dutch STI clinics (82) and 73\% in male partners of women with such disorders as cervical intraepithelial neoplasia (CIN) (86). MSM had lower positivity rates for genital (penile) but higher for anal HPV DNA than MSW (16\% vs 26\% and 33\% vs 4\%, respectively) (87). Most of the HPV studies in the Netherlands are focused on mucosal HPV types.

HPV vaccination is included in the Dutch National Immunization Program, which is free of charge (88). 


\section{C. trachomatis: microbiological characteristics, diagnostic and clinical aspects}

Ct is an obligatory intracellular, non-motile, Gram-negative bacterium, which belongs to the family Chlamydiaeceae has a complex biphasic developmental cycle and the independent reproduction lasting 24-48 hours (Fig. 3) (89-91).

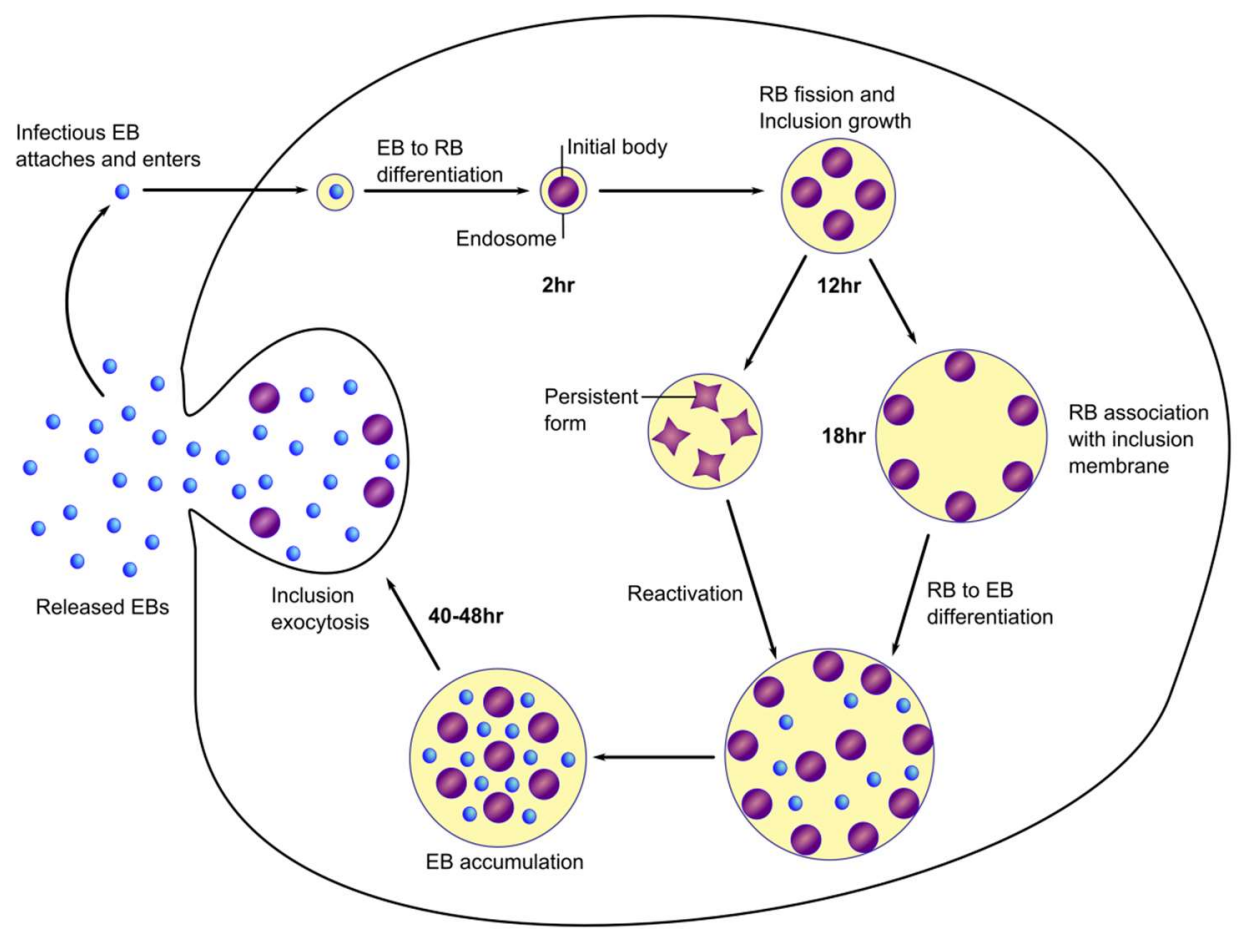

Figure 3. The development cycle of $\mathrm{C}$. trachomatis.

The development cycle consists of an extracellular and an intracellular parts. External metabolically inactive elementary bodies (EBs) are able to survive outside the cell and stay dormant until entering the host cell. The infection process starts with an EB attaching to a hostepithelial cell followed by cellular uptake. Intracellularly, the into-membrane-vacuolesinternalized EBs transform into metabolically active, non-infectious, reticulate bodies (RBs). RBs replicate and in the end of the intracellular cycle transform back into EBs. The latter are again released into the extracellular space by exocytosis or cell lysis and become able to infect other epithelial cells. Courtesy of Dr. S. Ouburg.

Most chlamydia infections are asymptomatic: up to $80 \%$ of women and $60 \%$ of men develop no symptoms. Asymptomatic infections are leading to undiagnosed cases (92). The genital Ct infection occurs in $45-75 \%$ of the cases with higher transmission rates in 
patients with symptomatic infection compared to those with an asymptomatic infection (93-95). Once infected, some patients may clear the infection without medication: up to $45 \%$ of the women clear the infection spontaneously after 1 year, $95 \%$ within 3 years (9597). However, some (a)symptomatic infections may not clear spontaneously and stay untreated.

The current golden standards for Ct detection NAATs and real time polymerase chain reactions (RT-PCR) tests are based on specific DNA or RNA amplification of Ct, highly specific and sensitive, quick to generate results (within 2 hours), relatively inexpensive and less labour intensive than other, commonly used in the past, tests (98-101), such as Ct testing based on Giemsa staining, cell culture, or monoclonal antibodies.

Ct comprises two biovars characterized by infections either localised in the epithelial surface of the conjunctiva or genital mucosa (the trachoma biovar includes ocular and urogenital strains) or able to spread systemically thorough the lymphatic system (strains of the lymphogranuloma venereum (LGV) biovar causing genital ulceration and bubonic disease) (102). The understanding of the diversity of Ct is mostly based on the primary surface antigen, the major outer membrane protein (MOMP), the largest component of the cell membrane that maintains the structural integrity of the cell wall, and its gene, ompA. Ct has evolved to include 19 serovars, or more properly genovars, originally based on antibody typing of MOMP (103) with over $60 \mathrm{ompA}$ genotypes (104-108), the gold standard typing technique for all Chlamydiaceae spp. The serovars are designated A through $\mathrm{K}, \mathrm{Ba}, \mathrm{Da}, \mathrm{Ia}, \mathrm{Ja}$, and L1-3, and L2a while the $\operatorname{ompA}$ genotypes or strains are denoted by the same or by a number or letter after the conventional serovar name (e.g., $\mathrm{D} 1 ; \mathrm{Ga}$ ) for new genotypes (105). Although ompA genotyping provides some further differentiation within these serotypes, it provides little or no detailed information about the nature of the infecting strain or the variation in the remaining $99.88 \%$ of the genome (102).

Ct genovars are responsible for of the broad spectrum of ocular (genovars A-C), anourogenital and oropharyngeal (D-K) infections and a LGV syndrome (L1-L3) (109114). Ocular infections include trachoma, a chronic ocular disease, and ophthalmia neonatorum (115), an infection acquired during passage through a Ct infected birth canal. Urogenital strains cause cervicitis, urethritis, and endometritis in women, resulting in pelvic inflammatory disease, infertility and ectopic pregnancy, and in men they cause urethritis, prostatitis and epididymitis (116-120). Rectal infections can progress to 
proctitis or inguinal syndrome (120-123). As the latter is caused primarily by LGV strains, of which strain L2b is the most important, and mainly prevalent among MSM $(124,125)$, very little is known about the prevalence of LGV among MSM in non-Western society (126). Infection with $\mathrm{Ct}$ increases the risk of acquisition of the human immunodeficiency virus (HIV) $(127,128)$ and the development of cervical cancer $(129,130)$.

Although serotyping of $\mathrm{Ct}$ is unnecessary for diagnosing a Ct infection, typing could be a tool to determine the current status of $\mathrm{Ct}$ infection, or to study evolution of specific $\mathrm{Ct}$ clones (131). The genome of $\mathrm{Ct}$ is highly conserved but a considerable amount of antigenic variation between genovars exists (132). However, the distribution of $\mathrm{Ct}$ serovars/genovars is nearly identical in most populations regardless of host risk group, geography, or calendar time, dominated by genovars D, E, and F, which comprise about $70 \%$ of STIs and, thus, making it difficult to follow transmission patterns accurately (133136). The exception to this is the distribution of genovars among MSM, for about $85 \%$ of whom the genovars are D, G, and J (131,137), as a result of different transmission dynamics. Finer, more holistic Multi Locus Sequence Typing (MLST) schemes have been developed to study the epidemiology and evolution of $\mathrm{Ct}$, and to track recombination events, differentiate new and persistent Ct infections (138-141). Two different MLST schemes $(139,140)$ are available, one based on fixed housekeeping genes with low variations for evolutionary studies, and one based on genes with frequent variation in part similar to that of ompA sequencing suitable for epidemiological and transmission studies. MLST is based on sequencing more targets besides ompA in genomes of $\mathrm{Ct}$ at the same time and discriminates a single genotype by ompA analysis into more than five. Less expensive than full genome sequencing, MLST discriminative power was estimated threefold than the ordinary sequencing $(138,142)$.

The thesis will study the distribution of Ct genital serovars/genovars in the Russian populations and compared them with available international data.

Treatment of genital Ct infection is often simple and effective. It includes primarily prescription either Azithromycin 1 gram single dose or, alternatively, Doxycycline $100 \mathrm{mg}$ for 7 days, for genital and pharyngeal infections, with achieve cure rates of 97-98\% (143). The latter antibiotic regimen is prescribed in case of anorectal non-LGV infection patients, while in case of an LGV infection, administered Doxycycline regimen is recommended to be extended for three weeks (144). LGV is a more invasive infection and may disseminate via the lymphatic system. Severe scarring and fibrosis of lymph nodes and destruction of 
(extra)genital sites may occur if LGV is not treated adequately (145). The thesis will investigate microbiological rationale for the prolonged treatment of LGV proctitis.

\section{HPV: microbiological characteristics, diagnostic and clinical aspects}

HPVs are a broad and diverse group of double-stranded DNA viruses that belongs to the family Papillomaviridae. Currently, more than 200 HPV types identified (146), which belong to the five genera, namely Alphapapillomavirus $(\alpha)$, Betapapillomavirus $(\beta)$, Gammapapillomavirus ( $\gamma$ ), Mupapillomavirus $(\mu)$ and Nupapillomavirus (v) (Fig. 4) (147150).

HPV infections in humans are strictly epitheliotropic and their life cycle takes place within stratified squamous epithelia (21). HPV infection requires access to basal cells through micro-abrasions in the epithelium (151). The mechanism for virus entry into the basal cells is not entirely understood. HPV infections are transmitted mainly through direct skin-to-skin or skin-to-mucosa contact $(21,152,153)$. HPVs can be categorized as mucosal or cutaneous based on their epithelial tropism (154). Three stages the life cycle of the virus include establishment, maintenance, and production (21). The HPV genome becomes established as a low copy-number nuclear plasmid in infected basal cells, with only early viral gene products expressed. The maintenance of HPV genome over multiple cell results in its long-term persistence over the years, but how it is achieved is still unclear. During the productive stage the daughter cells derived from the infected basal cells start to differentiate, the virus delays the differentiation programme of the cell, and redirects the cell's DNA replicative capacity, followed by viral amplification and expression of the genes necessary for the production of progeny virus, and subsequent viral release (21).

The majority of HPV infections do not cause symptoms or disease and resolve spontaneously (15,155), usually within two years (156-158) (Fig. 5.). However, persistent infection with HPV is a necessary cause of most of cervical and anal cancers, some cancers of the vagina, vulva, penis, rectum, oropharynx, head and neck, as well as skin or genital warts $(12,16,20,159,160)$. Mucosotropic HPVs are categorized into high- 
risk and low-risk types depending upon their degree of association with human malignancy (21).

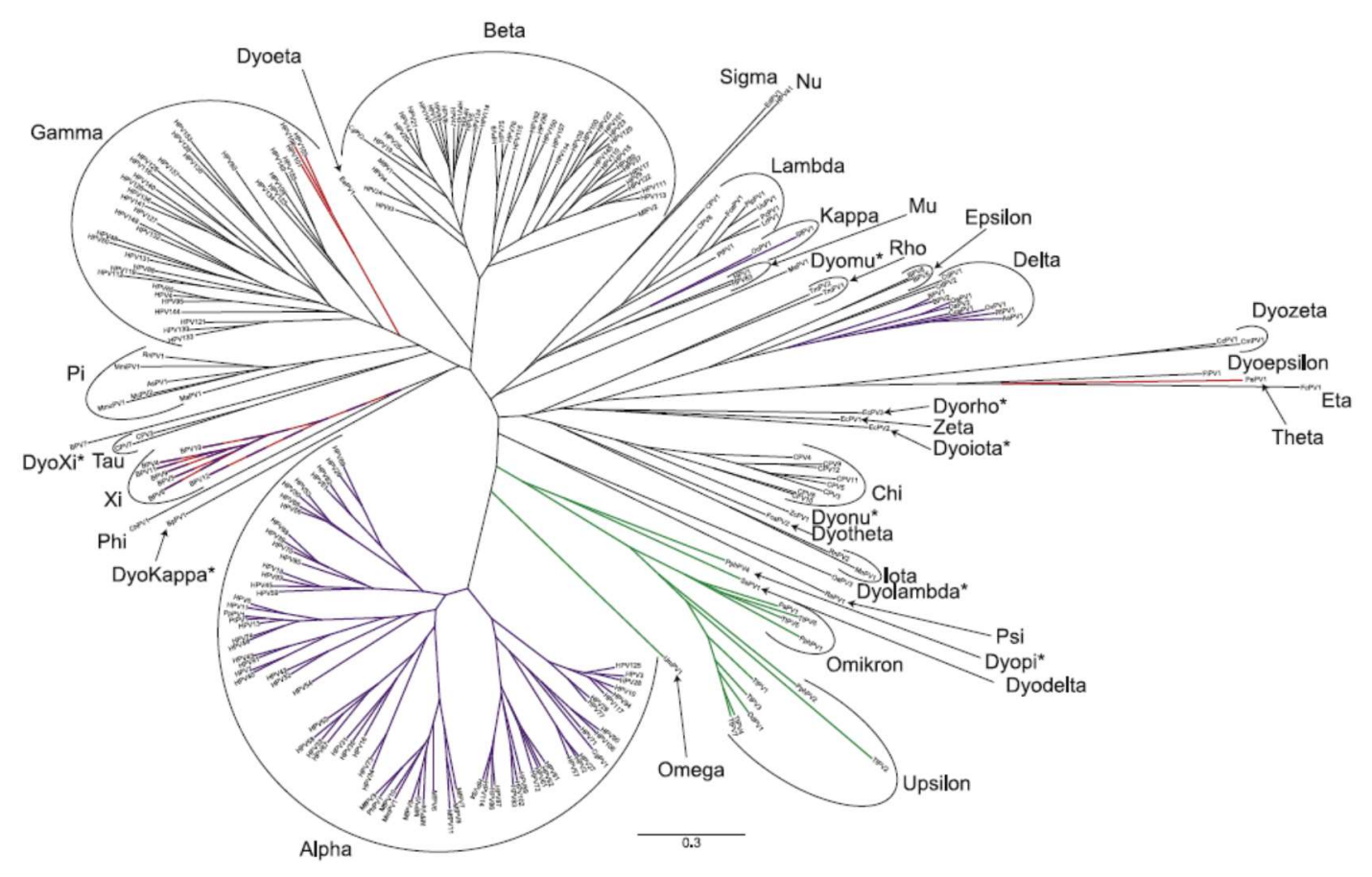

Figure 4. Phylogenetic tree of Papillomaviridae.

The different papillomavirus genera are named according to Bernard et al.(2010) (148) and de Villiers et al.(2004) (147). Reprinted from Virology 445(1-2), Van Doorslaer K, Evolution of the Papillomaviridae, pp 11-20, 2013 (150), with permission from Elsevier.

Sexually transmitted benign genital warts are primarily caused by $\alpha$-HPV types. The development of anogenital cancers has been associated with known 13 mucosal high-risk HPV types that belong to the $\alpha$-genus (21). There is some evidence of the oncogenic potential of non- $\alpha-H P V$, cutaneous types based on their proposed for $\beta$-HPVs (162-165) and speculated for $\gamma$-HPVs $(166,167)$ role in skin cancer. However, as compared to $\alpha$ HPVs, the distribution, etiology, and possible role of cutaneous types in the development of cancer has not yet been clearly established. There are no findings that support possible involvement in carcinogenesis $\gamma, \mu$ and $\nu$ genera.

Mucosal HPV infection is commonly found in the anogenital tract of men and women with and without clinical lesions. HPV is an incurable viral STI but the safe and highly effective HPV vaccination programmes are available as part of routine immunization 
programmes and primary cancer prevention strategy in 65 countries worldwide (1). The vaccines cannot treat HPV infection or HPV-associated disease such as cancer (16) but allow to prevent from the development of cervical and anal malignancies, and genital warts. The secondary cancer prevention strategy includes screening for pre-cancer and cancer among women who have no symptoms and may feel perfectly healthy by molecular testing for high-risk HPV types (168).

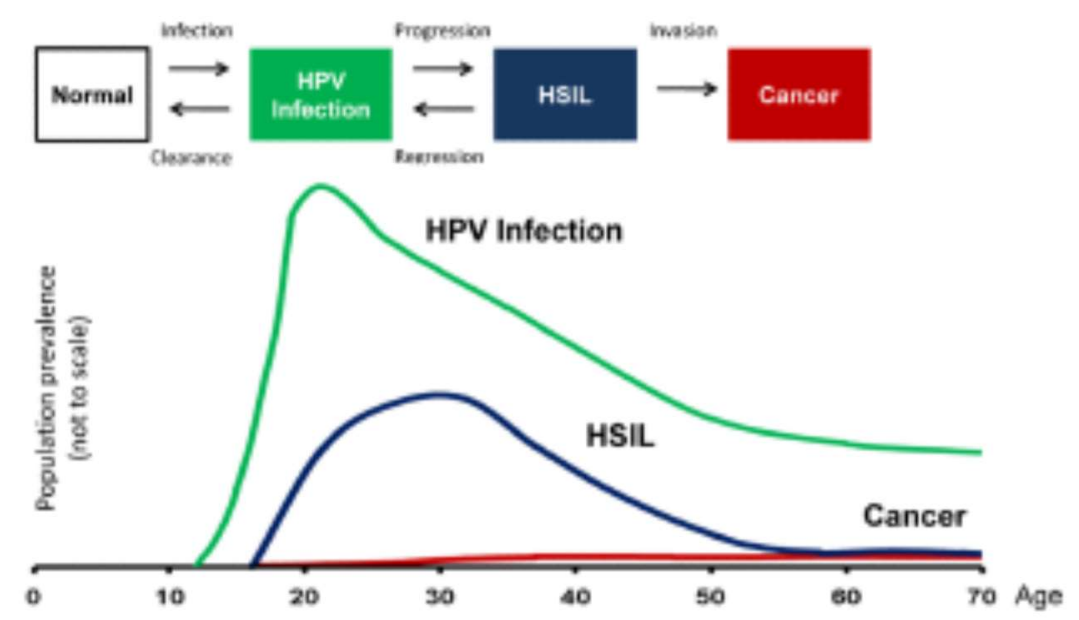

Figure 5. The natural history model and the corresponding prevalence of HPV infection, High Grade Squamous Intraepithelial Lesion (HSIL), and cancer in the population.

Reprinted from Cancer Epidemiology, Biomarkers \& Prevention 22(4), Schiffman M and Wentzensen N, Human papillomavirus (HPV) infection and the multi-stage carcinogenesis of cervical cancer, pp 553-560, 2013 (161), with permission from the American Association for Cancer Research.

An accurate and internationally comparable HPV DNA detection and typing methodology is an essential component in the evaluation of HPV vaccines or HPV-based screening programmes. Molecular HPV testing is rapidly being introduced and 193 distinct commercial HPV tests and at least 127 test variants available on the market currently (169). Worldwide, currently used genotyping assays differ in their analytical performance with regard to type-specific sensitivity and specificity (170-172). Efficient HPV genotyping can be achieved using bead-based multiplex genotyping of PCR amplimers obtained following general primer PCR (173), which allows to detect the broadest range of HPV types in a clinical specimen (173-175). Originally applied to the cervical samples in the studies in women, this approach can be used in the studies of HPV epidemiology in men. 
Studies of the epidemiology of HPV infection in men remain narrow but are essential for understanding HPV natural history, transmission dynamics and optimal uses of HPV vaccines. Research on optimal methods and anatomical sites for sampling are essential for enabling informative studies. Currently, among the most recommended anatomical sites for optimal HPV detection in heterosexual men are penile shaft and the glans penis/coronal sulcus, followed by scrotal, perianal, or anal samples (25). However, no studies on genital prevalence of $\alpha$-HPVs in men studied the detection of the virus in such media as expressed prostate secretion (EPS), which can be obtained during a routine urological diagnostic procedure digital rectal examination following massage of the prostate and remains the gold standard for assessing the bacteriological and inflammatory state of the lower urinary tract in urological patients (176). Data regarding the determinants of presence of a broad range of $\alpha$-HPVs in MSW and the anogenital distribution of cutaneous $\beta$ - and $\gamma$-HPV types in men are limited. The second chapter of the thesis will focus on the anogenital HPV epidemiology in men.

\section{Aims and outline of this thesis}

\section{Aims.}

Genital C. trachomatis and HPV are the two most prevalent STIs worldwide. The studies presented in this thesis investigate the epidemiology, novel approaches for the optimal sampling, detection and characterization of microorganisms, to provide insight into the better prevention, diagnostics and clinical management of infections and their complications.

\section{Outline.}

The thesis consists of two parts.

Part I is dedicated to the epidemiology, diagnostics and clinical management of chlamydia infections (Chapters 2-5).

Chapter 2 explores the epidemiology of genital chlamydia infections among women and men in Russia. As genital Ct infections constitute a major public health concern and the 
burden of infection in this large and diversely populated country is limited, a systematic literature review and analysis of the available data on Ct prevalence in Russia are performed, being strengthened with data from the multicenter study among several populations in the country's second-largest Russian megalopolis, St. Petersburg, testing for Ct in urethral, anal, cervical, and prostate samples.

In Chapter 3, chlamydia serogroup and serovar distributions in Russian men and women were determined, using the CT-DT detection and genotyping assay. The obtained data were compared with the data from Dutch serogroup and serovar distributions.

The chlamydia Multi Locus Sequence Typing (MLST) scheme is effective in differentiating Ct strain types, deciphering transmission patterns and treatment failure, and identifying recombinant strains. In Chapter 4, Ct reference and clinical samples from fifteen countries, including Russia, and five continents are analysed by MLST for seven housekeeping genes in detecting the sequence types concordant for the ompA genotype, to provide a more comprehensive analysis of the global diversification of Ct strain types.

In Chapter 5, the persistence of Ct DNA and RNA in anal swabs in ulcerative LGV (caused with Ct strains L1-3) and non-LGV (strains D-K) chlamydia proctitis treated with standard doxycycline treatment regimens is evaluated to support the recommendations on a clinical management of chlamydia-caused proctitis.

Part II is dedicated to the epidemiology and optimal sampling of HPV (Chapters 6-8) infections in men.

Exploring different sampling sites and methods is of interest for studies of the epidemiology of HPV infections in the male. In Chapter 6, the first-in-principle study explores if expressed prostate secretions are informative sample material for the study of HPV epidemiology in the male.

Data on anal cutaneous HPVs largely relies on studies among MSM and limited with geographical settings. A wide spectrum and moderate prevalence of anal $\beta$-HPV and $\gamma$ HPV types in Russian MSW is studied in Chapter 7.

The knowledge of determinants for the presence of anal HPV infections among men is limited. In Chapter 8, the determinants for the presence of a large number of mucosal 
HPV types in the anal canal samples obtained from a large cohort of Russian men are studied and analysed.

The general discussion is provided in Chapter 9. In this synthesis chapter the different epidemiological, diagnostic and clinical aspects of chlamydia and HPV infections are summarized and reviewed. Vision on better prevention, diagnostics and clinical management of the two STIs and recommendations for further research are provided.

\section{References}

1. WHO. Sexually transmitted infections (STIs) [Internet]. WHO. [cited 2017 Aug 1]. Available from:

http://www.who.int/mediacentre/factshe ets/fs110/en/

2. Gerbase AC, Rowley JT, Heymann DH, Berkley SF, Piot P. Global prevalence and incidence estimates of selected curable STDs. Sex Transm Infect. 1998 Jun;74 Suppl 1:S12-16.

3. WHO. Global Prevalence and Incidence of Selected Curable Sexually Transmitted Infections: Overview and Estimates [Internet]. Geneva: World Health Organization; 2001 [cited 2017 Aug 3]. Available from: http://www.who.int/hiv/pub/sti/who_hiv _aids_2001.02.pdf

4. WHO. Chlamydia trachomatis, Neisseria gonorrhoeae, syphilis and Trichomonas vaginalis. Methods and results used by WHO to generate 2005 estimates [Internet]. World Health Organization, Department of Reproductive Health and Research; 2011 [cited 2017 Aug 2]. Available from: http://apps.who.int/iris/bitstream/10665 /44735/1/9789241502450_eng.pdf

5. WHO. Global incidence and prevalence of selected curable sexually transmitted infections - 2008 [Internet]. World Health Organization, Department of Reproductive Health and Research; 2012 [cited 2017 Aug 2]. Available from: http://apps.who.int/iris/bitstream/10665 /75181/1/9789241503839_eng.pdf?ua=1
6. Newman L, Rowley J, Hoorn SV, Wijesooriya NS, Unemo M, Low N, et al. Global Estimates of the Prevalence and Incidence of Four Curable Sexually Transmitted Infections in 2012 Based on Systematic Review and Global Reporting. PLOS ONE. 2015 Dec 8;10(12):e0143304.

7. Rowley J, Toskin I, Ndowa F, World Health Organization, World Health Organization, Reproductive Health and Research. Global incidence and prevalence of selected curable sexually transmitted infections, 2008 [Internet]. Geneva, Switzerland: World Health Organization; 2012 [cited 2015 Oct 21]. Available from: http://apps.who.int/iris/bitstream/10665 /75181/1/9789241503839_eng.pdf

8. Franceschi S, Smith JS, van den Brule A, Herrero R, Arslan A, Anh P-T-H, et al. Cervical infection with Chlamydia trachomatis and Neisseria gonorrhoeae in women from ten areas in four continents. A cross-sectional study. Sex Transm Dis. 2007 Aug;34(8):563-9.

9. CDC. STD Surveillance Report Press Release: 2015 National Data for Gonorrhea, Chlamydia and Syphilis, 2016, Newsroom. CDC [Internet]. [cited 2017 Aug 30]. Available from: https://www.cdc.gov/nchhstp/newsroom /2016/std-surveillance-report-2015press-release.html

10. European Centre for Disease Prevention and Control. Annual Epidemiological Report 2016 - Chlamydia. [Internet]. Stockholm: ECDC; 2016 [cited 2017 August 30]. Available from: 
http://ecdc.europa.eu/en/healthtopics/Ch lamydia/Pages/Annual-epidemiological-re port-2016.aspx [Internet]. [cited 2017 Aug 30]. Available from:

https://ecdc.europa.eu/sites/portal/files/ documents/Chlamydia\%20AER.pdf

11. CDC. CSexually transmitted disease surveillance, 2009. Atlanta, GA: US Department of Health and Human Services, CDC; 2010.

12. CDC. STD Facts - Human papillomavirus (HPV) [Internet]. [cited 2015 Jun 5]. Available from: http://www.cdc.gov/std/hpv/stdfacthpv.htm

13. Satterwhite CL, Torrone E, Meites E, Dunne EF, Mahajan R, Ocfemia MCB, et al. Sexually transmitted infections among US women and men: prevalence and incidence estimates, 2008. Sex Transm Dis. 2013 Mar;40(3):187-93.

14. de Sanjosé S, Diaz M, Castellsagué X, Clifford G, Bruni L, Muñoz N, et al. Worldwide prevalence and genotype distribution of cervical human papillomavirus DNA in women with normal cytology: a meta-analysis. Lancet Infect Dis. 2007 Jul;7(7):453-9.

15. Forman D, de Martel C, Lacey CJ, Soerjomataram I, Lortet-Tieulent J, Bruni $\mathrm{L}$, et al. Global burden of human papillomavirus and related diseases. Vaccine. 2012 Nov 20;30 Suppl 5:F12-23.

16. WHO. Human papillomavirus (HPV) and cervical cancer [Internet]. WHO. [cited 2017 Aug 1]. Available from: http://www.who.int/mediacentre/factshe ets/fs380/en/

17. Widdice L, Ma Y, Jonte J, Farhat S, Breland D, Shiboski S, et al. Concordance and transmission of human papillomavirus within heterosexual couples observed over short intervals. J Infect Dis. 2013 Apr 15;207(8):1286-94.

18. Dunne EF, Nielson CM, Stone KM, Markowitz LE, Giuliano AR. Prevalence of HPV infection among men: A systematic review of the literature. J Infect Dis. 2006 Oct 15;194(8):1044-57.
19. Nyitray AG, da Silva RJC, Baggio ML, Lu B, Smith D 'elle, Abrahamsen M, et al. The prevalence of genital HPV and factors associated with oncogenic HPV among men having sex with men and men having sex with women and men: the HIM study. Sex Transm Dis. 2011 Oct;38(10):932-40.

20. ICO. World: Human Papillomavirus and Related Diseases, Summary Report 2017 [Internet]. ICO Information Centre on HPV and Cancer (HPV Information Centre); 2017 [cited 2017 Aug 3]. Available from: http://www.hpvcentre.net/statistics/repo rts/XWX.pdf

21. International Agency for Research on Cancer. IARC monographs on the evaluation of carcinogenic risks to humans, volume $100 \mathrm{~B}$, biological agents. Lyon: IARC; 2012.475 p.

22. Ferlay J, Shin H-R, Bray F, Forman D, Mathers C, Parkin DM. Estimates of worldwide burden of cancer in 2008: GLOBOCAN 2008. Int J Cancer. 2010 Dec 15;127(12):2893-917.

23. de Martel C, Ferlay J, Franceschi S, Vignat J, Bray F, Forman D, et al. Global burden of cancers attributable to infections in 2008: a review and synthetic analysis. Lancet Oncol. 2012 Jun;13(6):607-15.

24. Patel H, Wagner M, Singhal P, Kothari S. Systematic review of the incidence and prevalence of genital warts. BMC Infect Dis. 2013 Jan 25;13:39.

25. Giuliano AR, Nielson CM, Flores R, Dunne EF, Abrahamsen M, Papenfuss MR, et al. The optimal anatomic sites for sampling heterosexual men for human papillomavirus (HPV) detection: the HPV detection in men study. J Infect Dis. 2007 Oct 15;196(8):1146-52.

26. Borisenko KK, Tichonova LI, Renton AM. Syphilis and other sexually transmitted infections in the Russian Federation. Int J STD AIDS. 1999 Oct;10(10):665-8.

27. Order N286 of the Ministry of Health of the Russian Federation (in Russian). Приказ Минздрава РФ от 07.12.93 N286 0 совершенствовании контроля за заболеваниями, передаваемыми половым путем [Internet]. [cited 2017 Aug 8]. Available from: 
http://www.lawrussia.ru/texts/legal_673 /doc673a147x252.htm

28. Order N291 of the Ministry of Health of the Russian Federation (in Russian.) Приказ Минздрава РФ от 30.07.2001 N 291 о мерах по предупреждению распространения инфекций, передаваемых половым путем [Internet]. [cited 2017 Aug 8]. Available from:

http://www.lawrussia.ru/texts/legal_458 /doc458a375x255.htm

29. Renton AM, Borisenko KK, Meheus A, Gromyko A. Epidemics of syphilis in the newly independent states of the former Soviet Union. Sex Transm Infect. 1998 Jun;74(3):165-6.

30. Domeika M, Litvinenko I, Smirnova T, Gaivaronskaya 0, Savicheva A, Sokolovskiy $\mathrm{E}$, et al. Laboratory diagnostics for nonviral sexually transmitted infections in St. Petersburg, Russia: current situation and hallmarks for improvements. J Eur Acad Dermatol Venereol JEADV. 2008 Sep;22(9):1094-100.

31. Order N403 of the Ministry of Health of the Russian Federation (in Russian). Приказ Минздрава РФ от 12.08.2003 N403 об утверждении и введении в действие учетной формы N 089/ע-кв “извещение о больном с вновь установленным диагнозом сифилиса, гонореи, трихомоноза, хламидиоза, герпеса урогенитального, аногенитальными бородавками, микроспории, фавуса, трихофитии, микоза стоп, чесотки" [Internet]. [cited 2017 Aug 8]. Available from:

http://www.lawrussia.ru/texts/legal_744 /doc744a920x749.htm.

32. Domeika M, Hallén A, Karabanov L, Chudomirova K, Gruber F, Unzeitig V, et al. Chlamydia trachomatis infections in eastern Europe: legal aspects, epidemiology, diagnosis, and treatment. Sex Transm Infect. 2002 Apr;78(2):115-9.

33. ILO. The role of trade unions in the global economy and the fight against poverty. In International Labour Organization, 2005 [cited 2017 Aug 1]. Available from: http://www.ilo.org/wcmsp5/groups/publ ic/---ed_dialogue/--- actrav/documents/meetingdocument/wc ms_111311.pdf

34. Dehne KL, Khodakevich L, Hamers FF, Schwartländer B. The HIV/AIDS epidemic in eastern Europe: recent patterns and trends and their implications for policymaking. AIDS Lond Engl. 1999 May 7;13(7):741-9.

35. Atlani L, Caraël M, Brunet JB, Frasca T, Chaika N. Social change and HIV in the former USSR: the making of a new epidemic. Soc Sci Med 1982. 2000 Jun;50(11):1547-56.

36. Nemtsov AV. Estimates of total alcohol consumption in Russia, 1980-1994. Drug Alcohol Depend. 2000 Feb 1;58(1-2):13342.

37. Aral SO, St Lawrence JS. The ecology of sex work and drug use in Saratov Oblast, Russia. Sex Transm Dis. 2002 Dec;29(12):798-805.

38. Aral SO, St Lawrence JS, Tikhonova L, Safarova E, Parker KA, Shakarishvili A, et al. The social organization of commercial sex work in Moscow, Russia. Sex Transm Dis. 2003 Jan;30(1):39-45.

39. Shkolnikov V, McKee M, Leon DA. Changes in life expectancy in Russia in the mid1990s. Lancet Lond Engl. 2001 Mar 24;357(9260):917-21.

40. Ivanova MA, Vinogradova SA, Vartapetova NV, Malygina NS, Zalevskaja OV. The analysis of morbidity caused by sexually transmitted infections in population of the Russian Federation for the period of years 1997 - 2008 (Анализ заболеваемости населения Российской Федерации инфекциями, передаваемыми половым путем, за период с 1997 по 2008 гг. «Социальные аспекты здоровья населения» электронный научный журнал). Social Aspects of Population Health [Internet]. 2009 Aug 11 [cited 2017 Aug 9];3(11). Available from: http://vestnik.mednet.ru/content/view/1 38/30/lang,ru/

41. Kubanova AA, Lesnaya IN, Kubanov AA, Melekhina LY, Kaspirovich MA. Analysis of the epidemiological situation and dynamics of std and dermatosis morbidity in the territory of the russian federation 
(Анализ эпидемиологической ситуации и динамика заболеваемости инфекциями, передаваемыми половым путем, и дерматозами на территории Российской Федерации). Vestn Dermatol Venerol. 2010;5:4-21.

42. Ministry of Health of the Russian Federation, statistics (in Russian). Статистика от 21 июня 2005 г. [Internet]. [cited 2017 Aug 1]. Available from:

https://www.rosminzdrav.ru/documents/ 7948-statistika-ot-21-iyunya-2005-g

43. ECDC and WHO. Surveillance Report: HIV/AIDS Surveillance in Europe 2015 [Internet]. European Centre for Disease Prevention and Control (ECDC) and World Health Organization (WHO) Regional Office for Europe (WHO/Europe); 2016 [cited 2017 Aug 1]. Available from: http://www.euro.who.int/_data/assets/p df_file/0019/324370/HIV-AIDSsurveillance-Europe-2015.pdf?ua=1

44. WHO. CountryProfile - HIVCP_RUS.pdf [Internet]. [cited 2017 Aug 1]. Available from:

http://www.who.int/hiv/HIVCP_RUS.pdf

45. The Russian Federal Aids Centre (in Russian). Федеральный Центр СПИД [Internet]. [cited 2017 Aug 1]. Available from: http://www.hivrussia.ru/

46. Burruano L, Kruglov Y. HIV/AIDS epidemic in Eastern Europe: recent developments in the Russian Federation and Ukraine among women. Gend Med. 2009 Apr;6(1):277-89.

47. Ward H, Rönn M. The contribution of STIs to the sexual transmission of HIV. Curr Opin HIV AIDS. 2010 Jul;5(4):305-10.

48. WHO. CISID data on Chlamydia incidence in Russia [Internet]. [cited 2017 Aug 8]. Available from:

http://data.euro.who.int/cisid/?TabID=43 4000

49. Borisenko K. STD surveillance in the Russian Federation. Int J STD AIDS. 1998;9 Suppl 1:15.

50. Belkina T, Duvanova N, Karbovskaja J, Tebbens JD, Vlcek J. Antibiotic use practices of pharmacy staff: a cross- sectional study in Saint Petersburg, the Russian Federation. BMC Pharmacol Toxicol. 2017 Feb 14;18(1):11.

51. van Bergen J, Götz HM, Richardus JH, Hoebe CJPA, Broer J, Coenen AJT, et al. Prevalence of urogenital Chlamydia trachomatis increases significantly with level of urbanisation and suggests targeted screening approaches: results from the first national population based study in the Netherlands. Sex Transm Infect. 2005 Feb;81(1):17-23.

52. Macleod J, Salisbury C, Low N, McCarthy A, Sterne JAC, Holloway A, et al. Coverage and uptake of systematic postal screening for genital Chlamydia trachomatis and prevalence of infection in the United Kingdom general population: cross sectional study. BMJ. 2005 Apr 23;330(7497):940.

53. ICO Information Centre on HPV and Cancer (HPV Information Centre). Russian Federation: Human Papillomavirus and Related Diseases, Summary Report 2017 [Internet]. ICO Information Centre on HPV and Cancer (HPV Information Centre); 2017 Jul [cited 2017 Aug 10]. Available from:

http://hpvcentre.net/statistics/reports/R US.pdf

54. WHO. CISID data on HPV incidence in Russia [Internet]. [cited 2017 Aug 1]. Available from: http://data.euro.who.int/cisid/Default.asp $\mathrm{x}$ ?TabID=433212

55. WHO. WHO CISID data on STIs in Russia [Internet]. [cited 2017 Aug 9]. Available from:

http://data.euro.who.int/cisid/Default.asp $\mathrm{x}$ ?TabID=433212

56. Cáceres C, Konda K, Pecheny M, Chatterjee A, Lyerla R. Estimating the number of men who have sex with men in low and middle income countries. Sex Transm Infect. 2006 Jun;82 Suppl 3:iii3-9.

57. USAID. Men having sex with men in Eastern Europe: Implications of a hidden epidemic. Regional analysis report. [Internet]. AIDS Alliance USAID; 2010. Available from: http://ecom.ngo/wpcontent/uploads/2015/06/EECA-MSM- 
Regional-Report_Final_November-22010.pdf

58. Hylton E, Wirtz AL, Zelaya CE, Latkin C, Peryshkina A, Mogilnyi V, et al. Sexual Identity, Stigma, and Depression: the Role of the "Anti-gay Propaganda Law" in Mental Health among Men Who Have Sex with Men in Moscow, Russia. J Urban Health Bull N Y Acad Med. 2017 Jun;94(3):319-29.

59. Beyrer C, Baral SD, Collins C, Richardson ET, Sullivan PS, Sanchez J, et al. The global response to HIV in men who have sex with men. Lancet Lond Engl. 2016 Jul 9;388(10040):198-206.

60. The Russian AIDS Center. HIV infection in the Russian Federation, report (in Russian). ВИЧ-инфекция в Российской Федерации на 31 декабря 2014 г. Справка [Internet]. The Russian AIDS Center; 2014 Dec [cited 2017 Aug 11]. Available from:

http://www.hivrussia.ru/files/spravkaHI V2014.pdf

61. Russia at AIDS epidemic tipping point as HIV cases pass one million - official. Reuters [Internet]. 2016 Jan 21 [cited 2017 Aug 11]; Available from:

http://uk.reuters.com/article/uk-russiaaids-idUKKCNOUZ2AN

62. van Griensven F, de Lind van Wijngaarden JW, Baral S, Grulich A. The global epidemic of HIV infection among men who have sex with men. Curr Opin HIV AIDS. 2009 Jul;4(4):300-7.

63. Dukhovlinova E, Masharsky A, Toussova O, Verevochkin S, Solovyeva T, Meringof M, et al. Two Independent HIV Epidemics in Saint Petersburg, Russia Revealed by Molecular Epidemiology. AIDS Res Hum Retroviruses. 2015 Jun;31(6):608-14.

64. Chan PA, Robinette A, Montgomery M, Almonte A, Cu-Uvin S, Lonks JR, et al. Extragenital Infections Caused by Chlamydia trachomatis and Neisseria gonorrhoeae: A Review of the Literature. Infect Dis Obstet Gynecol. 2016;2016:5758387.

65. Barbee LA, Khosropour CM, Dombrowksi JC, Golden MR. New Human Immunodeficiency Virus Diagnosis
Independently Associated With Rectal Gonorrhea and Chlamydia in Men Who Have Sex With Men. Sex Transm Dis. 2017 Jul;44(7):385-9.

66. Kent CK, Chaw JK, Wong W, Liska S, Gibson S, Hubbard G, et al. Prevalence of rectal, urethral, and pharyngeal chlamydia and gonorrhea detected in 2 clinical settings among men who have sex with men: San Francisco, California, 2003. Clin Infect Dis Off Publ Infect Dis Soc Am. 2005 Jul 1;41(1):67-74.

67. Lissouba P, Van de Perre P, Auvert B. Association of genital human papillomavirus infection with HIV acquisition: a systematic review and metaanalysis. Sex Transm Infect. 2013 Aug;89(5):350-6.

68. Nyitray AG, Carvalho da Silva RJ, Baggio ML, Lu B, Smith D, Abrahamsen M, et al. Age-specific prevalence of and risk factors for anal human papillomavirus (HPV) among men who have sex with women and men who have sex with men: the HPV in men (HIM) study. J Infect Dis. 2011 Jan 1;203(1):49-57.

69. Schim van der Loeff MF, Mooij SH, Richel O, de Vries HJC, Prins JM. HPV and anal cancer in HIV-infected individuals: a review. Curr HIV/AIDS Rep. 2014 Sep;11(3):250-62.

70. Dukers-Muijrers NHTM, Niekamp A-M, Vergoossen MMH, Hoebe CJPA.

Effectiveness of an opting-out strategy for HIV testing: evaluation of 4 years of standard HIV testing in a STI clinic. Sex Transm Infect. 2009 Jun;85(3):226-30.

71. van Bergen JEAM, Kerssens JJ, Schellevis FG, Sandfort TG, Coenen TJ, Bindels PJ. Prevalence of STI related consultations in general practice: results from the second Dutch National Survey of General Practice. Br J Gen Pract J R Coll Gen Pract. 2006 Feb;56(523):104-9.

72. Trienekens SCM, Koedijk FDH, van den Broek IVF, Vriend HJ, Op de Coul ELM, van Veen $M G$, et al. Sexually transmitted infections, inluding HIV, in the Netherlands in 2011 [Internet]. Bilthoven, The Netherlands: 1. National Institute for Public Health and the Environment (RIVM) 2. Stichting HIV Monitoring (SHM) 3. 
Netherlands Institute for Health Services Research (NIVEL); 2012 Jun [cited 2017 Aug 31]. Report No.: RIVM report number: 201051001/2012. Available from: http://www.rivm.nl/bibliotheek/rapporte n/201051001.pdf

73. van Oeffelen AAM, van Aar F, van den Broek IVF, Op de Coul ELM, Woestenberg PJ, Heijne JCM, et al. Sexually transmitted infections, including HIV, in the Netherlands in 2014 [Internet]. Bilthoven, The Netherlands: National Institute for Public Health and the Environment; 2015 [cited 2017 Aug 31]. Report No.: RIVM report number: 2015-0041. Available from:

http://www.rivm.nl/dsresource?objectid= 8faaa360-ef4a-472c-af9c-

f965ed3bb009\&type=org\&disposition $=$ inli ne

74. van den Broek IVF, Verheij RA, van Dijk CE, Koedijk FDH, van der Sande MAB, van Bergen JEAM. Trends in sexually transmitted infections in the Netherlands, combining surveillance data from general practices and sexually transmitted infection centers. BMC Fam Pract. 2010 May 20;11:39.

75. de Vries R, van Bergen JEAM, de Jong-van den Berg LTW, Postma MJ, PILOT-CT Study Group. Systematic screening for Chlamydia trachomatis: estimating cost-effectiveness using dynamic modeling and Dutch data. Value Health J Int Soc Pharmacoeconomics Outcomes Res. 2006 Feb;9(1):1-11.

76. van Bergen J, Götz H, Richardus JH, Hoebe C, Broer J, Coenen T, et al. Prevalence of urogenital Chlamydia trachomatis infections in the Netherlands suggests selective screening approaches. Results from the PILOT CT Population Study. Drugs Today Barc Spain 1998. 2006 Mar;42 Suppl A:25-33.

77. van Bergen JEAM, Fennema JSA, van den Broek IVF, Brouwers EEHG, de Feijter EM, Hoebe CJPA, et al. Rationale, design, and results of the first screening round of a comprehensive, register-based, Chlamydia screening implementation programme in the Netherlands. BMC Infect Dis. 2010 Oct 7;10:293.

78. Nieuwenhuis RF, Ossewaarde JM, Götz HM, Dees J, Thio HB, Thomeer MGJ, et al.
Resurgence of lymphogranuloma venereum in Western Europe: an outbreak of Chlamydia trachomatis serovar 12 proctitis in The Netherlands among men who have sex with men. Clin Infect Dis Off Publ Infect Dis Soc Am. 2004 Oct 1;39(7):996-1003.

79. Heiligenberg M, Verweij SP, Speksnijder AGCL, Morré SA, de Vries HJC, Schim van der Loeff MF. No evidence for LGV transmission among heterosexuals in Amsterdam, the Netherlands. BMC Res Notes. 2014 Jun 10;7:355.

80. Lenselink CH, Melchers WJG, Quint WGV, Hoebers AMJ, Hendriks JCM, Massuger LFAG, et al. Sexual behaviour and HPV infections in 18 to 29 year old women in the pre-vaccine era in the Netherlands. PloS One. 2008;3(11):e3743.

81. Mollers M, Boot Hein J, Vriend Henrike J, King Audrey J, van den Broek Ingrid VF, van Bergen Jan E a. M, et al. Prevalence, incidence and persistence of genital HPV infections in a large cohort of sexually active young women in the Netherlands. Vaccine. 2013 Jan 2;31(2):394-401.

82. Vriend HJ, Boot HJ, van der Sande MAB, Medical Microbiological Laboratories, Municipal Health Services. Type-specific human papillomavirus infections among young heterosexual male and female STI clinic attendees. Sex Transm Dis. 2012 Jan;39(1):72-8.

83. Mollers M, Vriend HJ, van der Sande MAB, van Bergen JEAM, King AJ, Lenselink $\mathrm{CH}$, et al. Population- and type-specific clustering of multiple HPV types across diverse risk populations in the Netherlands. Am J Epidemiol. 2014 May 15;179(10):123646.

84. ICO Information Centre on HPV and Cancer (HPV Information Centre). Netherlands: Human Papillomavirus and Related Diseases, Summary Report 2017 [Internet]. ICO Information Centre on HPV and Cancer (HPV Information Centre) 2017; 2017 Jul [cited 2017 Sep 1]. Available from: http://hpvcentre.net/statistics/reports/N LD.pdf

85. Bleeker MCG, Hogewoning CJA, Voorhorst FJ, van den Brule AJC, Berkhof J, Hesselink 
AT, et al. HPV-associated flat penile lesions in men of a non-STD hospital population: less frequent and smaller in size than in male sexual partners of women with CIN. Int J Cancer. 2005 Jan 1;113(1):36-41.

86. Bleeker MCG, Hogewoning CJA, Berkhof J, Voorhorst FJ, Hesselink AT, van Diemen $\mathrm{PM}$, et al. Concordance of specific human papillomavirus types in sex partners is more prevalent than would be expected by chance and is associated with increased viral loads. Clin Infect Dis Off Publ Infect Dis Soc Am. 2005 Sep 1;41(5):612-20.

87. Vriend HJ, Bogaards JA, van der Klis FRM, Scherpenisse M, Boot HJ, King AJ, et al. Patterns of human papillomavirus DNA and antibody positivity in young males and females, suggesting a site-specific natural course of infection. PloS One. 2013;8(4):e60696.

88. RIVM. National Immunisation Programme - RIVM [Internet]. [cited 2017 Sep 1]. Available from: http://www.rivm.nl/en/Topics/N/Nation al_Immunisation_Programme

89. Moulder JW. Interaction of chlamydiae and host cells in vitro. Microbiol Rev. 1991 Mar;55(1):143-90.

90. Workowski KA, Berman S, Centers for Disease Control and Prevention (CDC). Sexually transmitted diseases treatment guidelines, 2010. MMWR Recomm Rep Morb Mortal Wkly Rep Recomm Rep. 2010 Dec 17;59(RR-12):1-110.

91. Choroszy-Król IC-K, Frej-Mądrzak M, JamaKmiecik A, Bober T, Jolanta Sarowska J. Characteristics of the Chlamydia trachomatis species - immunopathology and infections. Adv Clin Exp Med Off Organ Wroclaw Med Univ. 2012 Dec;21(6):799808.

92. Miller WC, Ford C a, Morris M, Handcock MS, Schmitz JL, Hobbs MM, et al. Prevalence of chlamydial and gonococcal infections among young adults in the United States. JAMA J Am Med Assoc. 2004 May 12;291(18):2229-36.

93. Markos A. The concordance of Chlamydia trachomatis genital infection between sexual partners, in the era of nucleic acid testing. Sex Health. 2005;2014.
94. Parks K, Dixon P. Spontaneous Clearance ofChlamydia trachomatisInfection in Untreated Patients. Sex Transm .... 1997;2:11-2.

95. Morré S a, van den Brule AJC, Rozendaal L, Boeke a JP, Voorhorst FJ, de Blok S, et al. The natural course of asymptomatic Chlamydia trachomatis infections: $45 \%$ clearance and no development of clinical PID after one-year follow-up. Int J STD AIDS. 2002 Dec;13 Suppl 2:12-8.

96. Molano M, Meijer CJLM, Weiderpass E, Arslan A, Posso H, Franceschi S, et al. The natural course of Chlamydia trachomatis infection in asymptomatic Colombian women: a 5-year follow-up study. J Infect Dis. 2005 Mar 15;191(6):907-16.

97. Land JA, Van Bergen JE a. M, Morré SA, Postma MJ. Epidemiology of Chlamydia trachomatis infection in women and the cost-effectiveness of screening. Hum Reprod Update. 2010 Apr;16(2):189-204.

98. Doing KM, Curtis K, Long JW, Volock ML. Prospective comparison of the Gen-probe PACE 2 assay and the Abbott ligase chain reaction for the direct detection of Chlamydia trachomatis in a low prevalence population. J Med Microbiol. 1999 May;48(5):507-10.

99. Fredlund H, Falk L, Jurstrand M, Unemo M. Molecular genetic methods for diagnosis and characterisation of Chlamydia trachomatis and Neisseria gonorrhoeae: impact on epidemiological surveillance and interventions. APMIS Acta Pathol Microbiol Immunol Scand. 2004 Dec;112(11-12):771-84.

100. Jespersen DJ, Flatten KS, Jones MF, Smith TF. Prospective comparison of cell cultures and nucleic acid amplification tests for laboratory diagnosis of Chlamydia trachomatis Infections. J Clin Microbiol. 2005 Oct;43(10):5324-6.

101. Gaydos CA. Nucleic acid amplification tests for gonorrhea and chlamydia: practice and applications. Infect Dis Clin North Am. 2005 Jun;19(2):367-386, ix.

102. Harris SR, Clarke IN, Seth-Smith HMB, Solomon AW, Cutcliffe LT, Marsh P, et al. Whole-genome analysis of diverse Chlamydia trachomatis strains identifies 
phylogenetic relationships masked by current clinical typing. Nat Genet. 2012 Apr;44(4):413-9, S1.

103. Wang SP, Grayston JT. Immunologic relationship between genital TRIC, lymphogranuloma venereum, and related organisms in a new microtiter indirect immunofluorescence test. Am J Ophthalmol. 1970 Sep;70(3):367-74.

104. Dean D, Millman K. Molecular and mutation trends analyses of omp1 alleles for serovar E of Chlamydia trachomatis. Implications for the immunopathogenesis of disease. J Clin Invest. 1997 Feb 1;99(3):475-83.

105. Batteiger BE, Wan R, Williams JA, He L, Ma A, Fortenberry JD, et al. Novel Chlamydia trachomatis strains in heterosexual sex partners, Indianapolis, Indiana, USA. Emerg Infect Dis. 2014 Nov;20(11):18417.

106. Isaksson J, Gallo Vaulet L, Christerson L, Ruettger A, Sachse K, Entrocassi C, et al. Comparison of multilocus sequence typing and multilocus typing microarray of Chlamydia trachomatis strains from Argentina and Chile. J Microbiol Methods. 2016 Aug;127:214-8.

107. Peuchant O, Touati A, Sperandio C, Hénin $\mathrm{N}$, Laurier-Nadalié C, Bébéar C, et al. Changing Pattern of Chlamydia trachomatis Strains in Lymphogranuloma Venereum Outbreak, France, 2010-2015. Emerg Infect Dis. 2016 Nov;22(11):19457.

108. Schillinger JA, Katz BP, Markowitz LE, Braslins PG, Shrier LA, Madico G, et al. Genotype-Specific Concordance of Chlamydia trachomatis Genital Infection Within Heterosexual Partnerships. Sex Transm Dis. 2016 Dec;43(12):741-9.

109. Van der Pol B. COBAS Amplicor: an automated PCR system for detection of $\mathrm{C}$. trachomatis and N. gonorrhoeae. Expert Rev Mol Diagn. 2002 Jul;2(4):379-89.

110. Geisler WM, Suchland RJ, Whittington WLH, Stamm WE. The relationship of serovar to clinical manifestations of urogenital Chlamydia trachomatis infection. Sex Transm Dis. 2003 Feb;30(2):160-5.
111. Gaydos CA, Theodore M, Dalesio N, Wood BJ, Quinn TC. Comparison of three nucleic acid amplification tests for detection of Chlamydia trachomatis in urine specimens. J Clin Microbiol. 2004 Jul;42(7):3041-5.

112. Bax CJ, Quint KD, Peters RPH, Ouburg S, Oostvogel PM, Mutsaers J a. EM, et al. Analyses of multiple-site and concurrent Chlamydia trachomatis serovar infections, and serovar tissue tropism for urogenital versus rectal specimens in male and female patients. Sex Transm Infect. 2011 Oct;87(6):503-7.

113. Mascellino MT, Boccia P, Oliva A. Immunopathogenesis in Chlamydia trachomatis Infected Women. ISRN Obstet Gynecol. 2011;2011:436936.

114. Verweij SP, Quint KD, Bax CJ, Van Leeuwen AP, Mutsaers J a. EM, Jansen CL, et al. Serogroup distribution of urogenital Chlamydia trachomatis in urban ethnic groups in The Netherlands. Epidemiol Infect. 2014 Feb;142(2):409-14.

115. Darville T. Chlamydia trachomatis infections in neonates and young children. Semin Pediatr Infect Dis. 2005 Oct;16(4):235-44.

116. Mårdh P-A. Tubal factor infertility, with special regard to chlamydial salpingitis. Curr Opin Infect Dis. 2004 Feb;17(1):4952.

117. Blas MM, Canchihuaman FA, Alva IE, Hawes SE. Pregnancy outcomes in women infected with Chlamydia trachomatis: a population-based cohort study in Washington State. Sex Transm Infect. 2007 Jul;83(4):314-8.

118. Baud D, Regan L, Greub G. Emerging role of Chlamydia and Chlamydia-like organisms in adverse pregnancy outcomes. Curr Opin Infect Dis. 2008 Feb;21(1):70-6.

119. Grabe M, Bartoletti R, Bjerklund Johansen TE, Cai T, Cek M, Köves B, et al. EAU Guidelines on Urological Infections. In: EAU Guidelines [Internet]. European Association of Urology; 2015 [cited 2015 Jun 18]. Available from: http://uroweb.org/wpcontent/uploads/19-Urologicalinfections_LR2.pdf 
120. Lanjouw E, Ouburg S, de Vries HJ, Stary A, Radcliffe K, Unemo M. 2015 European guideline on the management of Chlamydia trachomatis infections. Int J STD AIDS. 2016 Apr;27(5):333-48.

121. Sethi G, Allason-Jones E, Richens J, Annan NT, Hawkins D, Ekbote A, et al. Lymphogranuloma venereum presenting as genital ulceration and inguinal syndrome in men who have sex with men in London, UK. Sex Transm Infect. 2009 Jun;85(3):165-70.

122. Danby CS, Cosentino LA, Rabe LK, Priest CL, Damare KC, Macio IS, et al. Patterns of Extragenital Chlamydia and Gonorrhea in Women and Men Who Have Sex With Men Reporting a History of Receptive Anal Intercourse. Sex Transm Dis. 2016 Feb;43(2):105-9.

123. Labiran C, Marsh P, Zhou J, Bannister A, Clarke IN, Goubet $S$, et al. Highly diverse MLVA-ompA genotypes of rectal Chlamydia trachomatis among men who have sex with men in Brighton, UK and evidence for an HIV-related sexual network. Sex Transm Infect. 2016 Jun;92(4):299-304.

124. Spaargaren J, Fennema HSA, Morré SA, de Vries HJC, Coutinho RA. New lymphogranuloma venereum Chlamydia trachomatis variant, Amsterdam. Emerg Infect Dis. 2005 Jul;11(7):1090-2.

125. Spaargaren J, Schachter J, Moncada J, de Vries HJC, Fennema HSA, Peña AS, et al. Slow epidemic of lymphogranuloma venereum L2b strain. Emerg Infect Dis. 2005 Nov;11(11):1787-8.

126. de Vrieze NHN, de Vries HJC. Lymphogranuloma venereum among men who have sex with men. An epidemiological and clinical review. Expert Rev Anti Infect Ther. 2014 Jun;12(6):697704.

127. Wasserheit JN. Epidemiological synergy. Interrelationships between human immunodeficiency virus infection and other sexually transmitted diseases. Sex Transm Dis. 1992 Apr;19(2):61-77.

128. Chesson HW, Pinkerton SD. Sexually transmitted diseases and the increased risk for HIV transmission: implications for cost-effectiveness analyses of sexually transmitted disease prevention interventions. J Acquir Immune Defic Syndr 1999. 2000 May 1;24(1):48-56.

129. Wallin K-L, Wiklund F, Luostarinen T, Angström T, Anttila T, Bergman F, et al. A population-based prospective study of Chlamydia trachomatis infection and cervical carcinoma. Int J Cancer J Int Cancer. 2002 Oct 1;101(4):371-4.

130. Smith JS, Bosetti C, Muñoz N, Herrero R, Bosch FX, Eluf-Neto J, et al. Chlamydia trachomatis and invasive cervical cancer: a pooled analysis of the IARC multicentric case-control study. Int J Cancer J Int Cancer. 2004 Sep 1;111(3):431-9.

131. Pedersen LN, Herrmann B, Møller JK. Typing Chlamydia trachomatis: from egg yolk to nanotechnology. FEMS Immunol Med Microbiol. 2009 Mar;55(2):120-30.

132. Bom RJM, Christerson L, Schim van der Loeff MF, Coutinho RA, Herrmann B, Bruisten SM. Evaluation of high-resolution typing methods for Chlamydia trachomatis in samples from heterosexual couples. J Clin Microbiol. 2011 Aug;49(8):2844-53.

133. Lysén M, Osterlund A, Rubin C-J, Persson T, Persson I, Herrmann B. Characterization of ompA genotypes by sequence analysis of DNA from all detected cases of Chlamydia trachomatis infections during 1 year of contact tracing in a Swedish County. J Clin Microbiol. 2004 Apr;42(4):1641-7.

134. Hsu M-C, Tsai P-Y, Chen K-T, Li L-H, Chiang C-C, Tsai J-J, et al. Genotyping of Chlamydia trachomatis from clinical specimens in Taiwan. J Med Microbiol. 2006 Mar;55(Pt 3):301-8.

135. Mossman D, Beagley KW, Landay AL, Loewenthal M, Ooi C, Timms P, et al. Genotyping of urogenital Chlamydia trachomatis in Regional New South Wales, Australia. Sex Transm Dis. 2008 Jun;35(6):614-6.

136. Machado ACS, Bandea CI, Alves MFC, Joseph K, Igietseme J, Miranda AE, et al. Distribution of Chlamydia trachomatis genovars among youths and adults in Brazil. J Med Microbiol. 2011 Apr;60(Pt 4):472-6. 
137. Quint KD, Bom RJ, Quint WGV, Bruisten SM, van der Loeff MFS, Morré SA, et al. Anal infections with concomitant Chlamydia trachomatis genotypes among men who have sex with men in Amsterdam, the Netherlands. BMC Infect Dis. 2011 Mar 14;11:63.

138. Klint M, Fuxelius H-H, Goldkuhl RR, Skarin $\mathrm{H}$, Rutemark C, Andersson SGE, et al. Highresolution genotyping of Chlamydia trachomatis strains by multilocus sequence analysis. J Clin Microbiol. 2007 May;45(5):1410-4.

139. Pannekoek Y, Morelli G, Kusecek B, Morré SA, Ossewaarde JM, Langerak AA, et al. Multi locus sequence typing of Chlamydiales: clonal groupings within the obligate intracellular bacteria Chlamydia trachomatis. BMC Microbiol. 2008;8:42.

140. Dean D, Bruno WJ, Wan R, Gomes JP, Devignot S, Mehari T, et al. Predicting phenotype and emerging strains among Chlamydia trachomatis infections. Emerg Infect Dis. 2009 Sep;15(9):1385-94.

141. de Vries HJC, Schim van der Loeff MF, Bruisten SM. High-resolution typing of Chlamydia trachomatis: epidemiological and clinical uses. Curr Opin Infect Dis. 2015 Feb;28(1):61-71.

142. Jurstrand M, Christerson L, Klint M, Fredlund H, Unemo M, Herrmann B. Characterisation of Chlamydia trachomatis by ompA sequencing and multilocus sequence typing in a Swedish county before and after identification of the new variant. Sex Transm Infect. 2010 Feb;86(1):56-60.

143. Lau C-Y, Qureshi AK. Azithromycin versus doxycycline for genital chlamydial infections: a meta-analysis of randomized clinical trials. Sex Transm Dis. 2002 Sep;29(9):497-502.

144. de Vries HJC, Morré SA, White JA, Moi H. European guideline for the management of lymphogranuloma venereum, 2010. Int J STD AIDS. 2010 Aug;21(8):533-6.

145. Mabey D, Peeling RW. Lymphogranuloma venereum. Sex Transm Infect. 2002 Apr;78(2):90-2.
146. Reference clones at International HPV Reference Center [Internet]. [cited 2015 Jun 4]. Available from:

http://www.hpvcenter.se/html/refclones. html?\%3C?php\%20echo\%20time();\%20? $\% 3 \mathrm{E}$

147. de Villiers E-M, Fauquet C, Broker TR, Bernard H-U, zur Hausen H. Classification of papillomaviruses. Virology. 2004 Jun 20;324(1):17-27.

148. Bernard H-U, Burk RD, Chen Z, van Doorslaer K, zur Hausen H, de Villiers E-M. Classification of papillomaviruses (PVs) based on 189 PV types and proposal of taxonomic amendments. Virology. 2010 May 25;401(1):70-9.

149. de Villiers E-M. Cross-roads in the classification of papillomaviruses. Virology. 2013 Oct;445(1-2):2-10.

150. Van Doorslaer K. Evolution of the papillomaviridae. Virology. 2013 Oct;445(1-2):11-20.

151. Burchell AN, Calzavara LM, Orekhovsky V, Ladnaya NN, Russian HIV Response Network. Characterization of an emerging heterosexual HIV epidemic in Russia. Sex Transm Dis. 2008 Sep;35(9):807-13.

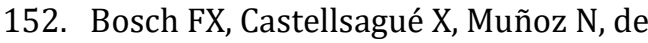
Sanjosé S, Ghaffari AM, González LC, et al. Male sexual behavior and human papillomavirus DNA: key risk factors for cervical cancer in Spain. J Natl Cancer Inst. 1996 Aug 7;88(15):1060-7.

153. Widdice L, Ma Y, Jonte J, Farhat S, Breland D, Shiboski S, et al. Concordance and transmission of human papillomavirus within heterosexual couples observed over short intervals. J Infect Dis. $2013 \mathrm{Apr}$ 15;207(8):1286-94.

154. Bzhalava D, Guan P, Franceschi S, Dillner J, Clifford G. A systematic review of the prevalence of mucosal and cutaneous human papillomavirus types. Virology. 2013 Oct;445(1-2):224-31.

155. Moreira ED, Giuliano AR, Palefsky J, Flores CA, Goldstone S, Ferris D, et al. Incidence, clearance, and disease progression of genital human papillomavirus infection in heterosexual men. J Infect Dis. 2014 Jul 15;210(2):192-9. 
156. Moscicki A-B, Schiffman M, Kjaer S, Villa LL. Chapter 5: Updating the natural history of HPV and anogenital cancer. Vaccine. 2006 Aug 31;24 Suppl 3:S3/42-51.

157. Ronco G, Dillner J, Elfström KM, Tunesi S, Snijders PJF, Arbyn M, et al. Efficacy of HPV-based screening for prevention of invasive cervical cancer: follow-up of four European randomised controlled trials. Lancet Lond Engl. 2014 Feb 8;383(9916):524-32.

158. Huh WK, Ault KA, Chelmow D, Davey DD, Goulart RA, Garcia FAR, et al. Use of primary high-risk human papillomavirus testing for cervical cancer screening: interim clinical guidance. Gynecol Oncol. 2015 Feb;136(2):178-82.

159. Herrero R, Castellsagué $X$, Pawlita $M$, Lissowska J, Kee F, Balaram P, et al. Human papillomavirus and oral cancer: the International Agency for Research on Cancer multicenter study. J Natl Cancer Inst. 2003 Dec 3;95(23):1772-83.

160. Monographs on the evaluation of carcinogenic risks to humans. In Lyon: International Agency for Research on Cancer.; 2012 [cited 2017 Aug 2]. Available from:

http://monographs.iarc.fr/ENG/Monogra phs/vol100B/mono100B-11.pdf

161. Schiffman M, Wentzensen N. Human papillomavirus infection and the multistage carcinogenesis of cervical cancer. Cancer Epidemiol Biomark Prev Publ Am Assoc Cancer Res Cosponsored Am Soc Prev Oncol. 2013 Apr;22(4):55360.

162. Proby CM, Harwood CA, Neale RE, Green AC, Euvrard S, Naldi L, et al. A case-control study of betapapillomavirus infection and cutaneous squamous cell carcinoma in organ transplant recipients. Am J Transplant Off J Am Soc Transplant Am Soc Transpl Surg. 2011 Jul;11(7):1498-508.

163. Neale RE, Weissenborn $S$, Abeni D, Bavinck JNB, Euvrard S, Feltkamp MCW, et al. Human papillomavirus load in eyebrow hair follicles and risk of cutaneous squamous cell carcinoma. Cancer Epidemiol Biomark Prev Publ Am Assoc Cancer Res Cosponsored Am Soc Prev Oncol. 2013 Apr;22(4):719-27.
164. Struijk L, Bouwes Bavinck JN, Wanningen $P$, van der Meijden E, Westendorp RGJ, Ter Schegget J, et al. Presence of human papillomavirus DNA in plucked eyebrow hairs is associated with a history of cutaneous squamous cell carcinoma. J Invest Dermatol. 2003 Dec;121(6):1531-5.

165. Pacini L, Savini C, Ghittoni R, Saidj D, Lamartine J, Hasan UA, et al. Downregulation of Toll-Like Receptor 9 Expression by Beta Human Papillomavirus 38 and Implications for Cell Cycle Control. J Virol. 2015 Nov;89(22):11396-405.

166. Waterboer T, Abeni D, Sampogna F, Rother A, Masini C, Sehr P, et al. Serological association of beta and gamma human papillomaviruses with squamous cell carcinoma of the skin. Br J Dermatol. 2008 Aug;159(2):457-9.

167. Paradisi A, Waterboer T, Sampogna F, Tabolli S, Simoni S, Pawlita M, et al. Seropositivity for human papillomavirus and incidence of subsequent squamous cell and basal cell carcinomas of the skin in patients with a previous nonmelanoma skin cancer. Br J Dermatol. 2011 Oct;165(4):782-91.

168. WHO. WHO guidelines for screening and treatment of precancerous lesions for cervical cancer prevention [Internet]. WHO Press, Geneva; 2013 [cited 2017 Aug 21]. Available from: http://apps.who.int/iris/bitstream/10665 /94830/1/9789241548694_eng.pdf

169. Poljak M, Kocjan BJ, Oštrbenk A, Seme K. Commercially available molecular tests for human papillomaviruses (HPV): 2015 update. J Clin Virol Off Publ Pan Am Soc Clin Virol. 2016 Mar;76 Suppl 1:S3-13.

170. Eklund C, Zhou T, Dillner J, WHO Human Papillomavirus Laboratory Network. Global proficiency study of human papillomavirus genotyping. J Clin Microbiol. 2010 Nov;48(11):4147-55.

171. Eklund C, Forslund O, Wallin K-L, Zhou T, Dillner J, WHO Human Papillomavirus Laboratory Network. The 2010 global proficiency study of human papillomavirus genotyping in vaccinology. J Clin Microbiol. 2012 Jul;50(7):2289-98. 
172. Eklund C, Forslund O, Wallin K-L, Dillner J. Global improvement in genotyping of human papillomavirus DNA: the 2011 HPV LabNet International Proficiency Study. J Clin Microbiol. 2014 Feb;52(2):449-59.

173. Schmitt M, Bravo IG, Snijders PJF, Gissmann L, Pawlita M, Waterboer T. Beadbased multiplex genotyping of human papillomaviruses. J Clin Microbiol. 2006 Feb;44(2):504-12.

174. Gheit T, Landi S, Gemignani F, Snijders PJF, Vaccarella S, Franceschi S, et al. Development of a sensitive and specific assay combining multiplex PCR and DNA microarray primer extension to detect high-risk mucosal human papillomavirus types. J Clin Microbiol. 2006 Jun;44(6):2025-31.

175. Gheit T, Billoud G, de Koning MNC, Gemignani F, Forslund O, Sylla BS, et al. Development of a sensitive and specific multiplex PCR method combined with DNA microarray primer extension to detect Betapapillomavirus types. J Clin Microbiol. 2007 Aug;45(8):2537-44.

176. EAU Guidelines on urological Infections. G. Bonkat (Co-chair), R. Pickard (Co-chair), R. Bartoletti, F. Bruyère, S.E. Geerlings, F. Wagenlehner, B. Wullt; members of the European Association of Urology (EAU) Urological Infections Guidelines Panel [Internet]. EAU Guidelines Office, Arnhem, The Netherlands; 2015 [cited 2017 Aug 21]. Available from: http://uroweb.org/guideline/urologicalinfections/\#3

177. Smelov V. Beta-HPV types in anal and genital sites among men: lack of concordance regardless of sexual orientation [Internet]. [cited 2017 Sep 6]; Cape Town, South Africa. Available from: http://hpv2017.org/Documents/HPV\%20 2017\%20Final\%20Program\%20SPIRAL.p df

178. Smelov V, Muwonge R, Hanisch R, McKayChopin S, Eklund C, Komyakov B, et al. Gamma-HPV types in anal and genital sites among men who have sex with women: lack of concordance. In Cape Town, South Africa; [cited 2017 Sep 6]. Available from: http://hpv2017.org/Documents/HPV\%20 2017\%20Final\%20Program\%20SPIRAL.p $\mathrm{df}$
179. Hernandez BY, Wilkens LR, Zhu X, Thompson P, McDuffie K, Shvetsov YB, et al. Transmission of human papillomavirus in heterosexual couples. Emerg Infect Dis. 2008 Jun;14(6):888-94.

180. Strauss S, Sastry P, Sonnex C, Edwards S, Gray J. Contamination of environmental surfaces by genital human papillomaviruses. Sex Transm Infect. 2002 Apr;78(2):135-8.

181. Smelov V, Eklund C, Arroyo Mühr LS, Hultin E, Dillner J. Are human papillomavirus DNA prevalences providing high-flying estimates of infection? An international survey of HPV detection on environmental surfaces. Sex Transm Infect. 2013 Dec;89(8):627.

182. Darwich L, Videla S, Cañadas M-P, Piñol M, García-Cuyàs F, Vela $S$, et al. Distribution of human papillomavirus genotypes in anal cytological and histological specimens from HIV-infected men who have sex with men and men who have sex with women. Dis Colon Rectum. 2013 Sep;56(9):104352.

183. Anderson TA, Schick V, Herbenick D, Dodge B, Fortenberry JD. A study of human papillomavirus on vaginally inserted sex toys, before and after cleaning, among women who have sex with women and men. Sex Transm Infect. 2014 Nov;90(7):529-31.

184. Gallay C, Miranda E, Schaefer S, Catarino R, Jacot-Guillarmod M, Menoud P-A, et al. Human papillomavirus (HPV) contamination of gynaecological equipment. Sex Transm Infect. 2015 Jun 12 ;

185. Di Bonito P, Della Libera S, Petricca S, Iaconelli M, Sanguinetti M, Graffeo R, et al. A large spectrum of alpha and beta papillomaviruses are detected in human stool samples. J Gen Virol. 2015 Mar;96(Pt 3):607-13.

186. Burd EM. Human Papillomavirus Laboratory Testing: the Changing Paradigm. Clin Microbiol Rev. 2016 Apr;29(2):291-319.

187. Johnson LG, Madeleine MM, Newcomer LM, Schwartz SM, Daling JR. Anal cancer incidence and survival: the surveillance, 
epidemiology, and end results experience, 1973-2000. Cancer. 2004 Jul

15;101(2):281-8.

188. Cancer of the Anus, Anal Canal, and Anorectum - SEER Stat Fact Sheets [Internet]. [cited 2015 Jun 4]. Available from:

http://seer.cancer.gov/statfacts/html/anu s.html 


\section{PART I.}

Chlamydia trachomatis infection 



\section{Chapter 2}

Prevalence of genital

Chlamydia trachomatis infections

in Russia: systematic literature

review and multicenter study 


\title{
Prevalence of genital \\ Chlamydia trachomatis infections in Russia: systematic literature review and multicenter study
}

\author{
Vitaly Smelov ${ }^{1,2,3,5}$, \\ Pierre Thomas ${ }^{1}$, \\ Rachel Hanisch ${ }^{4}$, \\ Sander Ouburg'2, \\ Servaas A. Morré1,2
}

Pathog Dis. 2017 Sep 29;75(7).

\begin{abstract}
${ }^{1}$ Institute of Public Health Genomics, Department of Genetics and Cell Biology, Research Institute GROW (School for Oncology and Developmental Biology), Faculty of Health, Medicine and Life Sciences, University of Maastricht, Maastricht, the Netherlands; ${ }^{2}$ Laboratory of Immunogenetics, Department of Medical Microbiology and Infection Control, VU University Medical Center, Amsterdam, the Netherlands; ${ }^{3}$ Prevention and Implementation Group, International Agency for Research on Cancer, World Health Organization, Lyon, France; ${ }^{4}$ Environmental Group, International Agency for Research on Cancer, World Health Organization, Lyon, France; ${ }^{5}$ Department of Urology, NorthWestern State Medical University named after I.I. Mechnikov, St. Petersburg, Russian Federation.
\end{abstract}




\begin{abstract}
A reliable overview of data on the prevalence of Chlamydia trachomatis (CT) in Russia is lacking and needed. All the available data on CT prevalence were analyzed in a systematic literature review on CT prevalence in Russia, strengthened with data from the multicenter study among 1263 people in the second-largest Russian megalopolis, St. Petersburg, testing for CT DNA in urethral, anal, cervical, and prostate samples. A total of 10 articles met the inclusion criteria. The overall average prevalence of genital CT infections in Russian populations ranged from $2.9 \%$ to $33 \%$. Risk factors included being symptomatic $(P=0.004$; in men $P<0.001)$, being younger than 30 years $(P=0.001)$, and being a man who has sex with men (MSM) $(P=0.0084)$. Main limitations included the lack of studies in MSM. CT prevalence was higher in the groups where urethral and prostate secretion samples were pooled (5.2-7.3\% vs 3.2\% in the urethra only).

The data on CT prevalence in a range of Russian populations is analyzed and reported. Prostate secretions represent an additional sampling material for the study of CT infection in men. CT detection in some settings in St. Petersburg yielded levels of reliability comparable with internationally available tests. The initiation of screening programs for Chlamydia infections in Russia should be considered.
\end{abstract}




\section{Introduction}

Chlamydia trachomatis (CT) is the most commonly detected bacterial sexually transmitted infection (STI) worldwide (WHO 2016; ECDC 2016; CDC 2017). Although most CT infections are asymptomatic (Detels et al. 2011; Clarivet et al. 2014), CT infection is a major cause of pelvic inflammatory diseases, ectopic pregnancy, and infertility (WHO, 2016) and increases the risk of HIV acquisition (Wasserheit 1992; Stamm 1999; Chesson and Pinkerton 2000; Røttingen, Cameron and Garnett 2001). The Joint United Nations Programme on HIV/AIDS (UNAIDS) in 2010 reported that the HIV prevalence in Russia is $1 \%$ or higher, with the growing HIV epidemic predominantly affecting drug users, sex workers, and vulnerable young people (UNAIDS 2010). However, reliable data on the incidence and prevalence of CT infections in the country are very limited (Smelov et al. 2009). There is currently no CT vaccine; therefore, early detection and reliable diagnosis are important, because CT infection can be treated with antibiotics.

In Russia, genital CT infection is a reportable STI, and for decades a state-controlled network of outpatient dispensaries for skin and venereal diseases was responsible for the diagnosis and treatment of STI. However, the collapse of the Soviet Union and economic liberalization in the 1990s changed the previously centralized health-care model into a mixed configuration, with private and state financing. This resulted in the current situation, where the exact number of different providers of venereological services (dispensaries, dermato-venereologists at larger general hospitals or outpatient clinics, etc.) is unknown (Domeika et al. 2008). Evaluations of some of the Russian nucleic acid amplification tests (NAATs) have shown that these tests yield similar levels of reliability compared with internationally available tests (Shipitsyna et al. 2009, 2012; Smelov et al. 2009). However, the available data on CT prevalence in Russia have been obtained only from small, high-risk populations, such as young (16-24 years) female university students (Khryanin, Reshetnikov and Vlaspolder 2007), male patients with acute urethritis (Taylor-Robinson et al. 2009), or young (15-19 years) people (Shipitsyna et al. 2013).

Extended knowledge on the prevalence of CT among diverse populations in this large and diversely populated country is of great importance. In addition to their value for epidemiological purposes or transmission studies, such analyses would have a direct clinical relevance and could be of significant help to public health policy-makers. Improved control of genital CT infections, i.e. by screening programs, could prevent the 
drop in fertility in Russia with the process of depopulation (Grigulevich 2012) and slow down the transmission of STIs, in particular the growing HIV epidemic (UNAIDS 2010).

This study had two components. First, we performed a systematic literature review and analyzed the available data on CT prevalence in Russia. Second, because data on the prevalence of CT infections in the country are limited, additional data were provided from a multicenter study performed in St. Petersburg in 2006-2009. These data were then used to assess the need to support the initiation of screening and prevention programs for CT infections.

\section{Materials and methods}

\section{Systematic literature review}

Articles and studies to be included in the review were obtained from the main scientific databases, PubMed and Embase, using the Medical Subject Headings (MeSH) terms "Chlamydia trachomatis" and "Russia". In addition, Google Scholar was screened using the same search criteria to include articles from non-indexed journals and "gray literature". The literature was limited to articles in English and Russian and to articles where a fulltext version could be accessed. The initial search was performed by screening the databases for all available articles until January 2017. We checked for duplicates among articles obtained from the databases, and all duplicates were excluded. Articles were included for review if they presented results from CT screening in defined populations in Russia. Articles were excluded if they featured testing on previously diagnosed CTpositive patients, tested the sensitivity of drugs, or described laboratory techniques or basic research on CT infection. In addition, the references of each article included for analysis were screened for potential additional articles on the subject.

\section{Multicenter study in St. Petersburg, Russia (2006-2009)}

\section{Study populations}

A multicenter study was performed from February 2006 to March 2009 in St. Petersburg, Russia. The study recruited attendees, who voluntarily provided samples to be tested for the presence of CT, at five clinics. The study recruited 1263 individuals: 1145 men and 118 women. The study participants were categorized into three groups. Group 1 comprised 915 men (mean age, 32 years; range, 18-52 years) seeking routine testing for 
STIs at a urology unit of either a university outpatient clinic (Group 1A) or one of two commercial non-venereological clinics (Groups $1 \mathrm{~B}$ and $1 \mathrm{C}$ ) providing services to the general population. Group 2 comprised 118 women (mean age, 36.3 years; range, 18-70 years) attending a gynecology unit of a university outpatient clinic (January-February 2007). Group 3 comprised 230 men (mean age, 33.9 years; range, 21-51 years) who were asymptomatic male partners of subfertile couples seeking assisted reproduction services at a fertility clinic (April 2006-March 2009); in Group 3, CT prevalence was analyzed using data obtained from medical records reviewed retrospectively.

Men and women were eligible for the study if they were at least 18 years old. All participants were evaluated with a detailed medical history and physical examination, including gynecological examination in women and digital rectal examination in men, during which the expressed prostate secretion (EPS) was collected. In addition, participants were asked questions about lifestyle and sexual behavior factors, such as the age at sexual debut, the number of lifetime sexual partners, sexual behavior, and history of STIs. Men who reported having had sex (anal or oral) with other men during their lifetime were categorized as men who have sex with men (MSM). Men who reported having had sex with only women were classified as men who have sex with women (MSW). To avoid decreasing the response rate, the questions about whether a man had ever had sex (anal or oral) with other men during his lifetime were asked before sampling, during the face-to-face interview by a single physician, who had been trained during the UNESCO-ASM Travel Award at the STI Outpatient clinic in Amsterdam. The replies were coded, and all participants were informed that the information would be confidential and not provided to any third parties. No data about same-sex sexual preferences was collected in women. No information about proper use of condoms was collected, because anyone seeking STI testing was considered to have experienced failure of condom use at least once. All participants provided blood samples for obligatory testing for HIV and Treponema pallidum antibodies. All anogenital samples obtained were tested with polymerase chain reaction (PCR) assays for CT, Neisseria gonorrhoeae, Trichomonas vaginalis, and herpes simplex virus (types 1 and 2 ) in St. Petersburg.

\section{Sampling procedures for CT testing}

Before sampling, male study participants in Group 1 were instructed to abstain from any form of sex for 3-5 days and from urination for 3-4 hours. The study physician obtained 
urethral and prostate (EPS) samples in parallel for a study on human papillomavirus (HPV) (Smelov et al. 2013) but pooled them for the current study on C. trachomatis (Groups 1A and 1B) or sampled only the distal part of the urethra where EPS was not collected (Group 1C). In MSM, the anal canal was sampled with a swab wetted in phosphate-buffered saline, and the swab was then rinsed in a tube containing $1000 \mu \mathrm{l}$ of phosphate-buffered saline. In women (Group 2), only cervical samples were obtained, as previously described (Shalepo et al. 2006), and were also rinsed in a tube containing 1000 $\mu \mathrm{l}$ of phosphate-buffered saline. No samples were prospectively collected in Group 3, as the samples had been previously analyzed and only the clinical data and CT results were collected and used.

After the material was obtained, all tubes containing the samples were immediately placed in a refrigerator at $4^{\circ} \mathrm{C}$ and at the end of the day were transferred into a freezer and stored at $-20^{\circ} \mathrm{C}$ prior to transportation and testing for CT infection in Amsterdam.

\section{Detection of CT}

In the samples from men in Group 1, the data on presence of CT previously detected in St. Petersburg with culture and domestic PCR assays (Shalepo et al. 2006; Smelov et al. 2009) was available. Briefly, conventional PCR (Lytech, Moscow, Russia) was applied to test the urethral samples in one laboratory, and real-time PCR (Central Research Institute of Epidemiology, Moscow, Russia) was applied to test the pooled urethral and EPS samples in another laboratory. These results were later confirmed in Amsterdam, by additional testing for CT DNA at the Laboratory of Immunogenetics (VU University Medical Center, Amsterdam, the Netherlands) as previously described in the CT serovar determination study (Smelov et al. 2009: 209). The results from a commercially available real-time PCR assay (TaqMan, Applied Biosystems, USA) (Morré et al. 1999) were additionally confirmed with the CE-IVD certified Presto CT-NG Assay (Goffin Molecular Technologies, Beek, the Netherlands) (Schuurs et al. 2013; de Waaij et al. 2015).

In the cervical samples from women in Group 2, the presence of CT was detected by the PCR assay (Lytech, Moscow, Russia) in St. Petersburg and confirmed in Amsterdam (Presto CT-NG Assay, Goffin Molecular Technologies, Beek, the Netherlands).

In the semen samples from men in Group 3, the data for this study was collected about the previous semen analysis and detection of CT DNA in the semen by PCR (Lytech, Moscow, Russia) in several commercial laboratories through St. Petersburg and analyzed. 


\section{Ethics}

Verbal informed consent was obtained from all study subjects after approval by the Local Institutional Review Board at D.O. Ott Research Institute of Obstetrics and Gynecology and the Russian Academy of Medical Sciences (RAMS), St. Petersburg, Russia (Shipitsyna et al. 2007). In addition, the study was approved in 2010 by the Department of Clinical Investigations and Intellectual Property of St. Petersburg Medical Academy of Postgraduate Studies (since 2011, North-Western State Medical University named after I.I. Mechnikov) under the Federal Agency of Public Health and Social Development of Roszdrav (Extract from Minutes No. 10 of SPbMAPS Ethical Committee meeting; date of approval: 10 November 2010), in accordance with the Declaration of Helsinki.

\section{Statistical analysis}

The chi-square or Fisher exact test was used to evaluate CT infection prevalence; 95\% confidence intervals $(95 \% \mathrm{CI})$ were calculated for all proportions, risk factors for CT infection, and logistic regression was conducted to determine factors associated with CT prevalence in a cross-sectional analysis by using GraphPad Instat statistical software (version 3.06; GraphPad Software Inc.).

\section{Results}

\section{Literature search}

The initial literature search yielded 33 original articles, based on screening of abstracts. A total of 24 articles were excluded from the review. Of those, eight studies featured drug sensitivity testing performed on CT-positive samples, seven articles described laboratory techniques, three articles provided results on serotypes of CT samples, and two articles provided information on multilocus sequence typing of CT-positive samples. In three other articles, we were not able to identify crucial information, such as the testing methods and the location of the study, and one article used PCR tests commercially available in Russia on a Swedish study population. The screening of the references of the initially included articles led to the inclusion of one additional article that met the requirements of the review. The results of the review of selected articles are summarized in the flowchart (Fig. 1). A total of 10 articles that met the inclusion criteria were retained for the review (Table 1). 


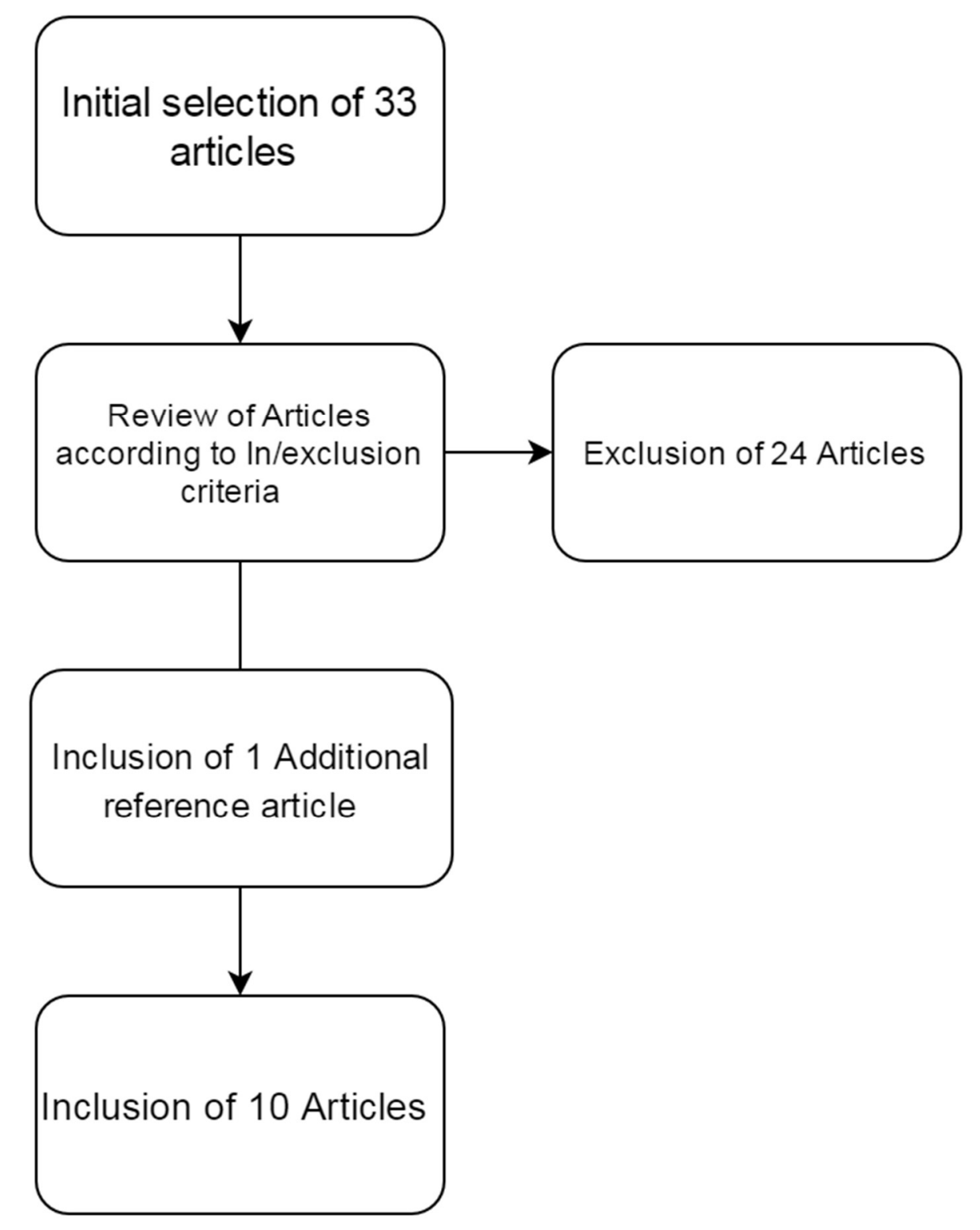

Figure 1. Flowchart of the review of selected articles.

\section{C. trachomatis prevalence and patient groups from the literature review}

The 10 articles included in the review yielded a CT prevalence ranging from $2.9 \%$ to $33 \%$. The highest prevalence was observed among symptomatic men attending STI clinics in Moscow (Renton et al. 2008) and Moscow Oblast (Taylor-Robinson et al. 2009). The lowest was recorded by Shipitsyna et al. among people attending gynecological, urological, and STI clinics in St. Petersburg (Shipitsyna et al. 2012). More than half (7/10) 
of the included studies featured populations with STI comorbidities (HIV, gonorrhea) presenting in health-care settings such as STI clinics and suffering from genitourinary symptoms (Shalepo et al. 2006; Renton et al. 2008; Shipitsyna et al. 2009, 2012; TaylorRobinson et al. 2009; Berle et al. 2012; Pace et al. 2012). Only two articles included in this review contained data from population screening (Shipitsyna et al. 2007; Berle et al. 2012). Most of the studies were performed in the western, most populated, part of Russia. More than half $(6 / 10)$ of the articles included in the review originated from St. Petersburg and the neighboring region of Leningrad Oblast (Shalepo et al. 2006; Shipitsyna et al. 2007, 2009, 2012, 2013; Pace et al. 2012). Two additional studies included in the review were conducted in the region of Moscow (Renton et al. 2008; Taylor-Robinson et al. 2009).

All of the included studies used PCR to detect CT. Both internationally available tests (i.e., Cobas Amplicor) and domestically developed tests are available in Russia.

\section{C. trachomatis prevalence from the multicenter study in St. Petersburg}

Overall, the prevalence of genital CT infections among people attending urological, gynecological, and family planning clinics in St. Petersburg ranged from 3\% to 7.3\% (Table 2).

Only $1.5 \%$ (14/915) of the Russian men in the study reported being MSM, but the prevalence of CT within this small high-risk group was 28.6\% $(P=0.0084)$. Among men attending urological clinics, CT DNA was detected in 3\% of urethral samples (Group 1C) and in 5.7\% (Group 1A) and 7.3\% (Group 1B) of pooled urethral and EPS samples. Among male partners of subfertile couples (Group 3), CT DNA was detected in $6.1 \%$ of semen samples; no significant differences in the number of leukocytes, sperm concentration or motility were detected between CT-positive and CT-negative samples. CT DNA was detected in $6.8 \%$ of the cervical samples (Group 2).

Risk factors included being symptomatic at the time of testing ( $P=0.004$, not shown), being younger than 30 years at the time of the study $(P=0.001)$, and having had more than 10 lifetime sexual partners $(P=0.0014)$ (Table 3). Urethral CT infection was more often detected in MSM $(P=0.0084)$. Symptoms were more common in CT-positive men $(63.6 \%)$ than in CT-positive women $(28.6 \%)(P<0.0001$, not shown). 
Table 1. Data on prevalence of Chlamydia trachomatis infection in the Russian population, studies in 2006-2012.

\begin{tabular}{|c|c|c|c|c|c|c|}
\hline Author (ref.) & Journal (year) & Location & Testing method & Study population & Samples tested & CT prevalence \\
\hline $\begin{array}{r}\text { Shipitsyna et al. (Shipitsyna } \\
\text { et al. 2013) }\end{array}$ & $\begin{array}{l}\text { J Eur Acad Dermatol } \\
\text { Venereol (2012) }\end{array}$ & St. Petersburg & NAAT & 432 young adults attending youth clinics & $\begin{array}{l}\text { Women: Cervical, vaginal and } \\
\text { urethral samples } \\
\text { Men: Urethral and urine samples }\end{array}$ & $13 \%$ \\
\hline $\begin{array}{r}\text { Shipitsyna et al. (Shipitsyna } \\
\text { et al. 2012) }\end{array}$ & $\begin{array}{l}\text { Acta Derm Venereol } \\
(2012)\end{array}$ & St. Petersburg & AmpliSens PCR & $\begin{array}{l}9294 \text { patients attending gynecological, urological, } \\
\text { and STI clinics }\end{array}$ & $\begin{array}{l}\text { Women: cervical swabs } \\
\text { Men: urethral swabs }\end{array}$ & $2.9 \%$ \\
\hline $\begin{array}{r}\text { Pace et al. (Pace et al. } \\
\text { 2012) }\end{array}$ & Int J STD AIDS (2012) & St. Petersburg & AmpliSens PCR & 682 HIV-infected heavy drinkers & Urine samples & $6.6 \%$ \\
\hline $\begin{array}{r}\text { Berle et al. (Berle et al. } \\
\text { 2012) }\end{array}$ & Int J STD AIDS (2012) & Arkhangelsk Oblast & $\begin{array}{l}\text { Russian commercial } \\
\text { PCR kit }\end{array}$ & $\begin{array}{l}1729 \text { patients in } 5 \text { groups: } 141 \text { outpatients at the } \\
\text { HIV centre and } 737 \text { at the STI clinic, } 200 \\
\text { university students, } 549 \text { military cadets recruited } \\
\text { in a military hospital, and } 83 \text { women seeking } \\
\text { abortion }\end{array}$ & FVU (5-10 ml) & $6.5 \%$ (range $3.8-14.9$ ) \\
\hline $\begin{array}{r}\text { Shipitsyna et al. (Shipitsyna } \\
\text { et al. 2009) }\end{array}$ & $\begin{array}{l}\text { J Eur Acad Dermatol } \\
\text { Venereol (2009) }\end{array}$ & St. Petersburg & Cobas Amplicor PCR & $\begin{array}{l}446 \text { consecutive symptomatic patients ( } 319 \\
\text { females, } 127 \text { males) }\end{array}$ & $\begin{array}{l}\text { Women: cervical and vaginal } \\
\text { Men: } 2 \text { urethral and } 1 \text { FVU }(25 \mathrm{ml})\end{array}$ & $12.6 \%$ \\
\hline $\begin{array}{l}\text { Taylor-Robinson et al. } \\
\text { (Taylor-Robinson et al. } \\
\text { 2009) }\end{array}$ & Int J STD AIDS (2009) & Moscow Oblast & LCR, PCR & 172 men with acute non-gonococcal urethritis & Urethral smears & $33 \%$ \\
\hline $\begin{array}{r}\text { Renton et al. (Renton et al. } \\
\text { 2008) }\end{array}$ & Int J STD AIDS (2008) & Moscow & LCR & $\begin{array}{l}176 \text { women and } 201 \text { men (both high-risk groups) } \\
\text { attending STI clinics }\end{array}$ & $\begin{array}{l}\text { Women: cervical smears } \\
\text { Men: urethral smears }\end{array}$ & $\begin{array}{l}19 \% \text { in women, } \\
33 \% \text { in men }\end{array}$ \\
\hline $\begin{array}{r}\text { Shipitsyna et al. (Shipitsyna } \\
\text { et al. 2007) }\end{array}$ & $\begin{array}{l}\text { Acta Derm Venereol } \\
\text { (2007) }\end{array}$ & Leningrad Oblast & In-house PCR & 1500 asymptomatic females & Endocervical samples & $6.6 \%$ \\
\hline $\begin{array}{r}\text { Khryanin et al. (Khryanin, } \\
\text { Reshetnikov and } \\
\text { Vlaspolder 2007) }\end{array}$ & Int J STD AIDS (2007) & Novosibirsk & $\begin{array}{l}\text { Aptima Combo } \\
\text { Amplicor PCR }\end{array}$ & $\begin{array}{l}100 \text { female university students voluntarily } \\
\text { participating in the study }\end{array}$ & Endocervical samples & $12 \%$ \\
\hline $\begin{array}{r}\text { Shalepo et al. (Shalepo et } \\
\text { al. 2006) }\end{array}$ & APMIS (2006) & St. Petersburg & $\begin{array}{l}\text { Culture, DFA, } \\
\text { in-house PCR }\end{array}$ & $\begin{array}{l}357 \text { women and } 253 \text { men in } 2 \text { groups: Group I } \\
\text { (urogenital complaints) and Group II (attendees } \\
\text { at gynecology outpatient clinic) }\end{array}$ & $\begin{array}{l}\text { Women: } 3 \text { cervical, } 1 \text { vaginal and } 3 \\
\text { urethral specimens } \\
\text { Men: } 3 \text { urethral specimens and } 1 \\
\text { samples of FVU ( } 30 \mathrm{ml})\end{array}$ & $\begin{array}{l}\text { Group I: } 26 \% \text { in women, } 30 \% \text { in } \\
\text { men } \\
\text { Group II: } 12 \% \text { in women, } 6.4 \% \\
\text { in men }\end{array}$ \\
\hline
\end{tabular}

DFA, direct fluorescent antibody; LCR, ligase chain reaction; NAAT, nucleic acid amplification test; PCR, polymerase chain reaction; FVU, first-void urine; CT, C. trachomatis. 
Table 2. Prevalence of genital Chlamydia trachomatis among male and female attendees at non-venereological clinics in St. Petersburg, Russia (2006-2009).

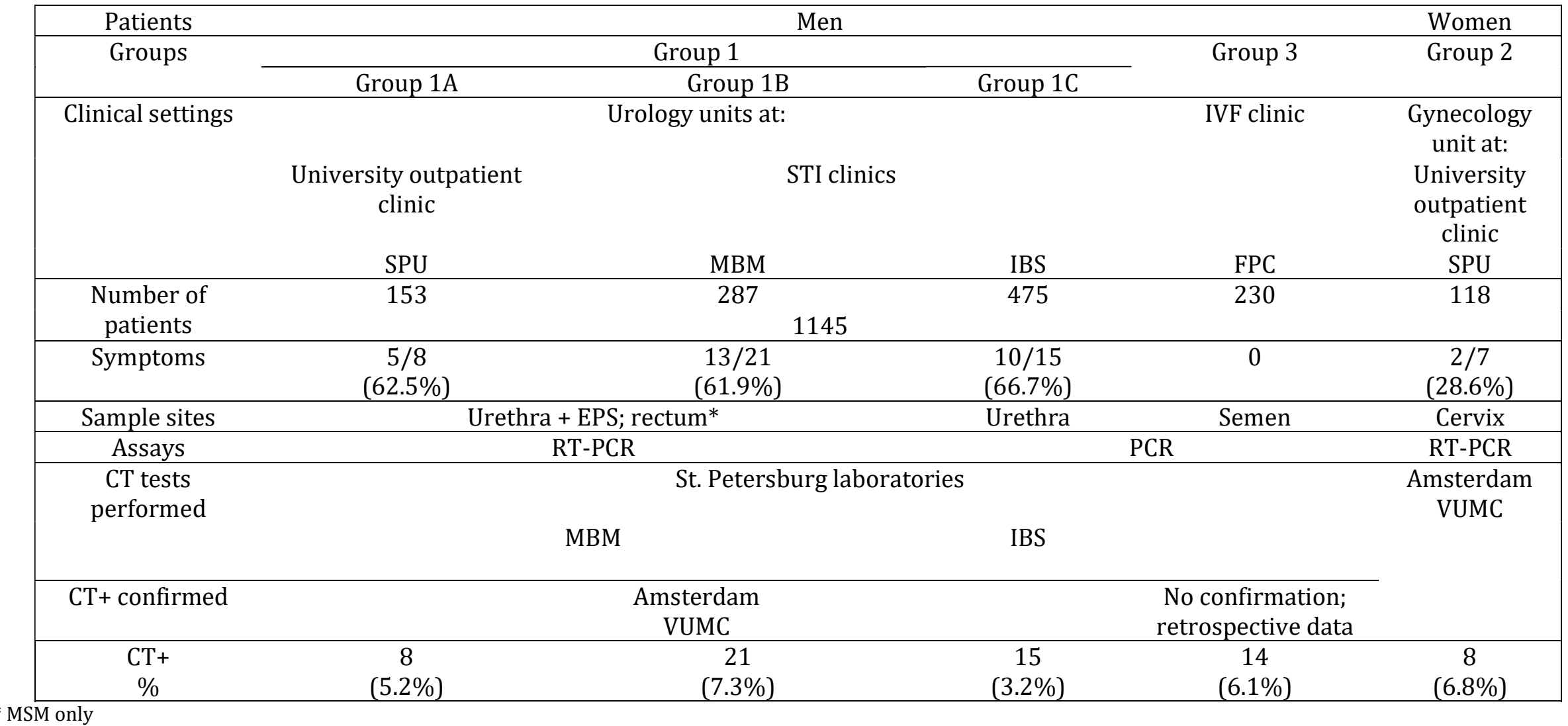

EPS, expressed prostate secretion; FPC, Pushkin Family Planning and Human Reproduction Center; IBS, ImmunoBioServis outpatient clinic; IVF, in vitro fertilization; MBM, Mikrobiomed outpatient clinic; MSM, men who have sex with men; (RT-)PCR, (real-time) polymerase chain reaction; SPU, St. Petersburg State University; VUMC, Laboratory of Immunogenetics, VU University Medical Center, Amsterdam 
Table 3. Factors associated with detection of genital Chlamydia trachomatis infection among "low-risk"1 male Russian populations: multivariable analyses.

\begin{tabular}{|c|c|c|c|c|c|}
\hline \multicolumn{2}{|l|}{ Factor } & \multicolumn{2}{|c|}{ Number of men, $\mathrm{CT}+/$ total } & $\begin{array}{c}\text { OR } \\
(95 \% \mathrm{CI})\end{array}$ & $P$-value \\
\hline \multirow{6}{*}{$\begin{array}{c}\text { Age at time of study, } \\
\text { years }\end{array}$} & \multirow{2}{*}{$18-24$} & $19 / 173$ & \multirow{6}{*}{$\begin{array}{l}<30 \text { years } \\
\text { vs } \\
\geq 30 \text { years }\end{array}$} & \multirow{6}{*}{$\begin{array}{c}2.37 \\
(1.4-4.02)\end{array}$} & \multirow{6}{*}{0.001} \\
\hline & & $(11.0 \%)$ & & & \\
\hline & $25-29$ & $19 / 240(6.7 \%)$ & & & \\
\hline & $30-34$ & $14 / 228(6.1 \%)$ & & & \\
\hline & $35-39$ & $3 / 144(2.1 \%)$ & & & \\
\hline & $\geq 40$ & $3 / 144(2.1 \%)$ & & & \\
\hline \multirow{4}{*}{$\begin{array}{c}\text { Age at sexual debut, } \\
\text { years }\end{array}$} & \multirow{2}{*}{$<16$} & $19 / 173$ & \multirow{4}{*}{$\begin{array}{c}<16 \text { years vs } \\
\geq 16 \text { years }\end{array}$} & \multirow{4}{*}{$\begin{array}{c}2.12 \\
(1.26-3.57)\end{array}$} & \multirow{4}{*}{0.0082} \\
\hline & & $(11.0 \%)$ & & & \\
\hline & $16-19$ & $33 / 582(5.7 \%)$ & & & \\
\hline & $\geq 20$ & $6 / 170(3.5 \%)$ & & & \\
\hline \multirow{7}{*}{$\begin{array}{c}\text { Number of lifetime } \\
\text { sexual partners }\end{array}$} & $1-2$ & $2 / 53(3.8 \%)$ & & \multirow{7}{*}{$\begin{array}{c}0.44 \\
(0.26-0.74)\end{array}$} & \multirow{7}{*}{0.0014} \\
\hline & $3-5$ & $2 / 139(1.4 \%)$ & $1-10$ & & \\
\hline & $6-10$ & $14 / 224(6.3 \%)$ & partners & & \\
\hline & & $19 / 183$ & vs & & \\
\hline & $11-20$ & $(10.4 \%)$ & $\geq 11$ & & \\
\hline & $21-100$ & $22 / 209(6.5 \%)$ & partners & & \\
\hline & $\geq 100$ & 9/113 (7.8\%) & & & \\
\hline \multirow{2}{*}{ Sexual behavior } & MSW & $54 / 920(5.9 \%)$ & MSM vs & 4.87 & \multirow{2}{*}{0.0084} \\
\hline & MSM & $4 / 14(28.6 \%)$ & MSW & $(2.04-11.6)$ & \\
\hline \multirow{2}{*}{$\begin{array}{c}\text { C. trachomatis } \\
\text { infection treated in the } \\
\text { past }\end{array}$} & Never & $45 / 613(7.3 \%)$ & \multirow{2}{*}{$\begin{array}{l}\mathrm{CT}+\text { in the } \\
\text { past vs } \\
\text { naive }\end{array}$} & 1.75 & \multirow[b]{2}{*}{0.0837} \\
\hline & Reported & $13 / 309(4.2 \%)$ & & $(0.96-3.19)$ & \\
\hline
\end{tabular}

95\%CI, 95\% confidence interval; CT, Chlamydia trachomatis; MSM, men who have sex with men; MSW, men who have sex with women; OR, odds ratio.

${ }^{1}$ The study populations were considered to have a "low-risk" profile as none of the participants reported engaging in commercial sex or intravenous drug use, the mean age of participants was above 30 years in all groups, and prevalences of other STIs were low 
Regarding STIs, HIV was detected in only two MSW, and N. gonorrhea was diagnosed in one MSW (urethra) and one MSM (urethra and anal canal). Current CT detection was not correlated with the history of being treated for CT infection in the past $(P=0.0837)$.

All samples found to be CT-positive by Russian NAATs in St. Petersburg although limited in number (66), were confirmed as true CT-positive by the two PCR assays in Amsterdam.

\section{Discussion}

This study is the first to summarize the current knowledge on the prevalence of genital CT infections in Russia. In this respect, the data from several clinics, with varying sample sizes and varying modes of recruitment could be considered as a strength of the study. From the literature review, CT prevalence in Russian populations attending STI clinics was found to range from $2.9 \%$ to $33 \%$. In the multicenter study in St. Petersburg, most of the study populations were considered to have a "low-risk" profile (none of the participants reported engaging in commercial sex or intravenous drug use, the mean age of participants was above 30 years in all groups, and prevalences of other STIs were low), and the CT prevalence was found to be about $6 \%$. The risk factors included being younger than 30 years at the time of the study, being symptomatic at the time of testing, and being a MSM.

This study had several limitations. First, in the systematic literature review the geographical location of the included studies is not representative of Russia as a whole. The results included in this study provide a thorough overview of CT prevalence in predominantly western Russia (except one study in Novosibirsk), but the results cannot be extrapolated to the whole country. The study populations featured in the included articles do not overlap in terms of patient characteristics and testing and diagnostic methods. Most of the studies performed CT testing on specific patient populations, who were overall at a high risk for STIs. Therefore, a meta-analysis based on these patient populations could not be performed, due to these differences in study characteristics. The current multicenter study, unfortunately, cannot be considered as representative for the whole country either: the geographical coverage of the sample population was limited (all five centers were located in St. Petersburg), in addition almost all of the "low-risk" participants were aware of the alarming (UNAIDS 2010) situation regarding HIV 
prevalence in Russia and reported they knew their HIV status and many were in STI clinics.

Among important limitations of the multicenter study was the very limited data on CT prevalence in MSM. Although the impact of the stigma on uptake of HIV/STI services has been stressed (Baral et al. 2012), research on MSM in Russia remains delicate, due to the perceptions and experiences of stigma (USAID 2010; Niccolai et al. 2013; Wirtz et al. 2014). Thus, the first data on HIV prevalence (3.5-6.0\%) and risk factors in MSM in St. Petersburg and Moscow, which recently became available (van Griensven et al. 2009; USAID 2010; Baral et al. 2012), may not reflect the true prevalence. Although we cannot exclude possible bias due to the conservative attitudes to homosexuality in the country, the multicenter study in St. Petersburg presented the first data on the prevalence of CT infection among MSM, who were recruited out of the gay scene (i.e., gay bars, sexual networks, etc.). Although in the study the vast majority of men reported having had sex with only women and only $1.5 \%$ of the men were categorized as MSM, strikingly, CT infection was detected in about one quarter of MSM. Routine screening of MSM for STIs can result in a decline in the incidence of CT infections and HIV (Xiridou et al. 2013), but this might require a less stigmatized approach towards MSM.

Genital CT infection has been reported to increase the risk of HIV acquisition (Wasserheit 1992; Stamm 1999; Chesson and Pinkerton 2000; Røttingen, Cameron and Garnett 2001), but surprisingly few data were available about HIV prevalence among the studied populations in all reviewed articles. This could be explained by the long-time practice in the country of requiring a medical check-up, which includes obligatory HIV testing in a venereological dispensary, for any job application or in the case of hospitalization.

Testing for CT is a part of diagnostic assessment of individuals applying for fertility treatment in Russia. In the multicenter study, we present the first data on CT DNA detection in $6.1 \%$ of semen samples from "low-risk" men, who reported being in steady relationships for more than 1 year and planned to apply for assisted reproduction services. Importantly, the majority of men had poor knowledge about the transmission routes of CT infections and their sequelae (data not shown). Although the data were collected in 2006-2009, the current CT prevalence may not differ significantly. The current growing numbers of HIV-positive people (UNAIDS, 2010), with a reported shift of HIV transmission routes in Russia towards more sexual transmission (Lowndes, Alary 
and Platt 2003; Abdala et al. 2008; Burchell et al. 2008), raise concerns about the potential for the increase in HIV transmission from high-risk groups to a more generalized epidemic (Lowndes, Alary and Platt 2003; Abdala et al. 2008; Burchell et al. 2008).

Our findings support the recently reported lack of significant differences between infertile and fertile men in terms of CT prevalence (Liu et al. 2014). A significant impact of CT infection on the female reproductive system has been well described (Paavonen and Eggert-Kruse 1999), but the role of CT infection in male infertility remains controversial. CT has been detected in the semen (Levy et al. 1999), the fluid of seminal vesicles (Furuya et al. 2004), EPS (Smelov et al. 2004), and prostate tissues (Corradi et al. 1996; Krieger and Riley 2002), but it is difficult to exclude possible urethral contamination. Epidemiological data have suggested a possible association between past CT infection and male infertility (Karinen et al. 2004), but the biological significance of CT infection on male infertility is accepted for acute epididymitis and consecutive azoospermia only (Eley and Pacey 2011), and further studies are needed.

In the detection of CT, NAATs have generally been accepted as the method of choice (48). Although the use of suboptimal diagnostic techniques was considered a major problem in Russia (Smelov et al. 2009), in recent years several domestic diagnostic systems have been developed in the country for the detection of CT DNA and RNA (Domeika et al. 2002; Shalepo et al. 2006). The total cost of diagnostic CT PCR of one sample, including test kits, consumables, technician's salaries, and other related costs, was calculated as US\$2.6 (Shipitsyna et al. 2007). Some of the Russian NAATs have yielded similar levels of reliability compared with some commercially available FDA approved and CE-IVD certified tests, commonly used in the Netherlands (Smelov et al. 2009) and Sweden (Shipitsyna et al. 2009, 2012). These results suggest that the testing and diagnosis methods in place in the studies featured in the literature review comply with the gold standards for CT detection. The domestically produced tests dominate the market and could be used in further studies on CT prevalence. Improvements are still required in the system of case reporting, the training of laboratory personnel, and the level of interlaboratory communication (Domeika et al. 2008).

International cooperation would be of great value, not only in better prevention of CT/STI or HIV acquisition but also for epidemiological purposes and transmission studies, especially given the increasing number of cross-border and overseas trips, which also result in expanding international sexual networks. The emergence of Russian CT 
serotypes in Finland is indicated by the increased CT seroprevalence in Finnish border towns (Lyytikäinen et al. 2008). Moreover, although neither CT LGV (lymphogranuloma venereum) infection nor the new "Swedish" variant of CT (swCT) were detected in St. Petersburg in 2009 (Smelov et al. 2009), the first case of swCT was detected in one female sample in Russia in 2009 already (Shipitsyna et al. 2012). In a study on CT prevalence in selected populations in five countries, the incidence of asymptomatic CT infection in women in St. Petersburg was found to be high (4.9\%) (Detels et al. 2011).

There is currently no vaccine against CT infections, and early detection plays a crucial role in decreasing the numbers of CT-infected people. Novel detection methods and anatomical sites for optimal CT sampling are of high interest. In the multicenter study in St. Petersburg, diverse genital samples obtained in women (cervical swabs) and men (urethral and anal swabs, semen samples, and prostate secretion samples) were tested for CT.

No studies on self-collected or home-collected samples for CT testing in Russia have been reported. Cervical (Shalepo et al. 2006; Shipitsyna et al. 2007, 2009, 2012, 2013; Smelov et al. 2009) and, less often, vaginal (Shipitsyna et al. 2009) swabs are the specimens of choice in testing women for CT in Russia. The samples are usually obtained by clinicians or trained nurses, because these personnel have relatively low salaries and also because Russian patients expect to interact with health-care experts (Grau et al. 2013). In men, first-void urine samples were accepted in the early 1990s for detection of genital CT (Chernesky et al. 1990) and are now recommended for routine detection (Eley 2011). A noninvasive urine sample contains a high organism load, but male urethral swabs are still a useful alternative (Eley 2011). In Russia, sampling of the male distal urethra was originally mandatory for culture tests and microscopy. Interestingly, when NAATs became less expensive and more widespread, urethra sampling still remained the most common practice (Shalepo et al. 2006; Shipitsyna et al. 2007, 2009, 2012, 2013; Smelov et al. 2009). Semen is another popular sample because it is self-taken and not painful. Moreover, the collection of semen is obligatory for sperm analysis in andrology clinics or fertility centers. This practice allowed us to obtain the data on CT prevalence in the semen samples in the study in St. Petersburg. However, the methodology for the testing of semen for CT has not been approved (Chernesky 2005) and should be studied (Eley 2011; Eley and Pacey 2011). Interestingly, CT prevalence was higher in the groups where the EPS specimens were pooled with the urethral ones. Testing multiple specimens 
tends to detect a higher number of CT infections (Vincelette et al. 1999; Schachter et al. 2005; Shalepo et al. 2006). Potentially, EPS may represent an additional sampling material for the study of CT infection in men, as has been shown for HPV (Smelov et al. 2013).

In conclusion, the prevalence of genital CT infections may be high among some populations in Russia. While further studies should be focused on high-risk or stigmatized populations, the increase in HIV prevalence among the general population calls for a national program to improve screening programs for CT infection in Russia.

\section{Funding}

This work was supported in part by a United Nations Educational, Scientific and Cultural Organization (UNESCO)-American Society for Microbiology (ASM) International Travel Award (to V. Smelov, 2006) and the European Urological Scholarship Programme (Clinical Fellowship 2007 to V. Smelov). The work was in part undertaken during the tenure of a postdoctoral fellowship from the International Agency for Research on Cancer, partially supported by the European Commission FP7 Marie Curie Actions-People-Cofunding of regional, national, and international programmes (COFUND) (to V. Smelov, 2013). The funders had no role in study design, data collection, and analysis.

\section{Acknowledgements}

The authors are grateful to the personnel of the Laboratory of Microbiology at the D.O. Ott Research Institute of Obstetrics and Gynecology, the St. Petersburg State University outpatient clinic, the Mikrobiomed and ImmunoBioServis outpatient clinics, and the Family Planning and Human Reproduction Center in Pushkin (all in St. Petersburg, Russia), and the Laboratory of Immunogenetics at the VU University Medical Center (Amsterdam, the Netherlands) for their dedicated technical and administrative support. The authors thank Karen Müller for editing the manuscript.

Conflicts of interest. None declared. 


\section{References}

Abdala N, Krasnoselskikh TV, Durante AJ et al.

Sexually transmitted infections, sexual risk behaviors and the risk of heterosexual spread of HIV among and beyond IDUs in St. Petersburg, Russia. Eur Addict Res 2008;14:19-25.

Baral S, Sifakis F, Peryskina A et al. Risks for HIV infection among gay, bisexual, and other men who have sex with men in Moscow and St. Petersburg, Russia. AIDS Res Hum Retroviruses 2012;28:874-9.

Berle LM, Firsova N, Kalashnik A et al. Chlamydia trachomatis, Mycoplasma genitalium and Ureaplasma urealyticum in clinical and non-clinical settings, Arkhangelsk Oblast, Russia. Int J STD AIDS 2012;23:781-4.

Burchell AN, Calzavara LM, Orekhovsky V et al. Characterization of an emerging heterosexual HIV epidemic in Russia. Sex Transm Dis 2008;35:807-13.

Centers for Disease Control and Prevention (CDC). Chlamydia. CDC Fact Sheet, 2017. http://www.cdc.gov/std/chlamydia/stdfa ct-chlamydia.htm (date last accessed, 12 June 2017).

Chernesky M, Castriciano S, Sellors J et al. Detection of Chlamydia trachomatis antigens in urine as an alternative to swabs and cultures. J Infect Dis 1990;161:124-6.

Chernesky MA. The laboratory diagnosis of Chlamydia trachomatis infections. Can J Infect Dis Med Microbiol 2005;16:39-44.

Chesson HW, Pinkerton SD. Sexually transmitted diseases and the increased risk for HIV transmission: implications for costeffectiveness analyses of sexually transmitted disease prevention interventions. J Acquir Immune Defic Syndr 1999 2000;24:48-56.

Clarivet B, Picot E, Marchandin $\mathrm{H}$ et al. Prevalence of Chlamydia trachomatis, Neisseria gonorrhoeae and Mycoplasma genitalium in asymptomatic patients under 30 years of age screened in a French sexually transmitted infections clinic. Eur J Dermatol 2014;24:611-6.

Corradi G, Bucsek M, Pánovics J et al. Detection of Chlamydia trachomatis in the prostate by in-situ hybridization and by transmission electron microscopy. Int J Androl 1996;19:109-12.

Detels R, Green AM, Klausner JD et al. The incidence and correlates of symptomatic and asymptomatic Chlamydia trachomatis and Neisseria gonorrhoeae infections in selected populations in five countries. Sex Transm Dis 2011;38:503-9.

Domeika M, Hallén A, Karabanov L et al. Chlamydia trachomatis infections in eastern Europe: legal aspects, epidemiology, diagnosis, and treatment. Sex Transm Infect 2002;78:115-9.

Domeika M, Litvinenko I, Smirnova T et al. Laboratory diagnostics for non-viral sexually transmitted infections in St. Petersburg, Russia: current situation and hallmarks for improvements. J Eur Acad Dermatol Venereol 2008;22:1094-100.

European Centre for Disease Prevention and Control (ECDC). Chlamyida. Five infectious diseases accounted for $75 \%$ of reported cases in EU - summary report, 2016. http://ecdc.europa.eu/en/healthtopics/ch lamydia/Pages/index.aspx (date last assessed, 12 June 2017). 
Eley A. How to detect Chlamydia trachomatis in males? J Androl 2011;32:15-22.

Eley A, Pacey AA. The value of testing semen for Chlamydia trachomatis in men of infertile couples. Int J Androl 2011;34:391-401.

Furuya R, Takahashi S, Furuya S et al. Is seminal vesiculitis a discrete disease entity? Clinical and microbiological study of seminal vesiculitis in patients with acute epididymitis. J Urol 2004;171:1550-3.

Grau LE, Krasnoselskikh TV, Shaboltas AV et al. Cultural adaptation of an intervention to reduce sexual risk behaviors among patients attending a STI clinic in St. Petersburg, Russia. Prev Sci 2013;14:40010.

van Griensven F, de Lind van Wijngaarden JW, Baral S et al. The global epidemic of HIV infection among men who have sex with men. Curr Opin HIV AIDS 2009;4:300-7.

Grigulevich NI. Population decline in the central region of Russian Federation (1990-2010). Coll Antropol 2012;36:1101-8.

The Joint United Nations Programme on HIV/AIDS (UNAIDS). Global Report: UNAIDS Report on the Global AIDS Epidemic 2010. Geneva: UNAIDS, 2010. http://www.unaids.org/globalreport/doc uments/20101123_GlobalReport_full_en.p df (date last assessed, 12 June 2017).

Karinen L, Pouta A, Hartikainen AL et al. Association between Chlamydia trachomatis antibodies and subfertility in the Northern Finland Birth Cohort 1966 (NFBC 1966), at the age of 31 years. Epidemiol Infect 2004;132:977-84.

Khryanin AA, Reshetnikov OV, Vlaspolder F. Comparison of APTIMA COMBO 2 assay with polymerase chain reaction Roche assay for detection of Chlamydia trachomatis in endocervical swabs. Int $J$ STD AIDS 2007;18:871-2.

Krieger JN, Riley DE. Prostatitis: what is the role of infection. Int J Antimicrob Agents 2002;19:475-9.

Levy R, Layani-Milon MP, Giscard D’Estaing S et al. Screening for Chlamydia trachomatis and Ureaplasma urealyticum infection in semen from asymptomatic male partners of infertile couples prior to in vitro fertilization. Int J Androl 1999;22:113-8.

Liu J, Wang Q, Ji X et al. Prevalence of Ureaplasma urealyticum, Mycoplasma hominis, Chlamydia trachomatis infections, and semen quality in infertile and fertile men in China. Urology 2014;83:795-9.

Lowndes CM, Alary M, Platt L. Injection drug use, commercial sex work, and the HIV/STI epidemic in the Russian Federation. Sex Transm Dis 2003;30:46-8.

Lyytikäinen E, Kaasila M, Koskela P et al. Chlamydia trachomatis seroprevalence atlas of Finland 1983-2003. Sex Transm Infect 2008;84:19-22.

The United States Agency for International Development (USAID). AIDS Support and Technical Assistance Resources. Men having sex with men in Eastern Europe: Implications of a hidden HIV epidemic. Regional analysis report, 2010. http://ecom.ngo/wpcontent/uploads/2015/06/EECA-MSMRegional-Report_Final_November-22010.pdf (date last accessed, 12 June 2017).

Morré SA, Van Valkengoed IG, Moes RM et al. Determination of Chlamydia trachomatis prevalence in an asymptomatic screening population: performances of the LCX and 
COBAS Amplicor tests with urine specimens. J Clin Microbiol 1999;37:3092-

6.

Niccolai LM, King EJ, Eritsyan KU et al. "In different situations, in different ways": male sex work in St. Petersburg, Russia. Cult Health Sex 2013;15:480-93.

Paavonen J, Eggert-Kruse W. Chlamydia trachomatis: impact on human reproduction. Hum Reprod Update 1999;5:433-47.

Pace CA, Lioznov D, Cheng DM et al. Sexually transmitted infections among HIV-infected heavy drinkers in St Petersburg, Russia. Int J STD AIDS 2012;23:853-8.

Renton A, Filatova E, Ison C et al. Performance of direct fluorescent antibody tests for routine diagnosis of Chlamydia trachomatis in Russian sexually transmitted disease clinics. Int J STD AIDS 2008;19:851-5.

Røttingen JA, Cameron DW, Garnett GP. A systematic review of the epidemiologic interactions between classic sexually transmitted diseases and HIV: how much really is known? Sex Transm Dis 2001;28:579-97.

Schachter J, Hook EW, Martin DH et al. Confirming positive results of nucleic acid amplification tests (NAATs) for Chlamydia trachomatis: all NAATs are not created equal. J Clin Microbiol 2005;43:1372-3.

Schuurs TA, Verweij SP, Weel JFL et al. Detection of Chlamydia trachomatis and Neisseria gonorrhoeae in an STI population: performances of the Presto CT-NG assay, the Lightmix Kit 480 HT CT/NG and the COBAS Amplicor with urine specimens and urethral/cervicovaginal samples. BMJ Open 2013;3:e003607.
Shalepo K, Savicheva A, Shipitsyna E et al. Diagnosis of Chlamydia trachomatis in Russia--in-house PCR assays may be effective but overall optimization and quality assurance are urgently needed. APMIS 2006;114:500-7.

Shipitsyna E, Hadad R, Ryzhkova 0 et al. First reported case of the Swedish new variant of Chlamydia trachomatis (nvCT) in Eastern Europe (Russia), and evaluation of Russian nucleic acid amplification tests regarding their ability to detect nvCT. Acta Derm Venereol 2012;92:330-1.

Shipitsyna E, Krasnoselskikh T, Zolotoverkhaya E et al. Sexual behaviours, knowledge and attitudes regarding safe sex, and prevalence of non-viral sexually transmitted infections among attendees of youth clinics in St. Petersburg, Russia. J Eur Acad Dermatol Venereol 2013;27:e75-84.

Shipitsyna E, Shalepo K, Savicheva A et al. Pooling samples: the key to sensitive, specific and cost-effective genetic diagnosis of Chlamydia trachomatis in lowresource countries. Acta Derm Venereol 2007;87:140-3.

Shipitsyna E, Zolotoverkhaya E, Agné-Stadling I et al. First evaluation of six nucleic acid amplification tests widely used in the diagnosis of Chlamydia trachomatis in Russia. J Eur Acad Dermatol Venereol 2009;23:268-76.

Smelov V, Eklund C, Bzhalava D et al. Expressed prostate secretions in the study of human papillomavirus epidemiology in the male. PloS One 2013;8:e66630.

Smelov V, Perekalina T, Gorelov A et al. In vitro activity of fluoroquinolones, azithromycin and doxycycline against chlamydia trachomatis cultured from men with 
chronic lower urinary tract symptoms. Eur Urol 2004;46:647-50.

Smelov V, Quint KD, Pleijster J et al. Chlamydia trachomatis serovar distributions in Russian men and women: a comparison with Dutch serovar distributions. Drugs Today (Barc) 2009;45 Suppl B:33-8.

Stamm WE. Chlamydia trachomatis infections: progress and problems. J Infect Dis 1999;179 Suppl 2:S380-383.

Taylor-Robinson D, Renton A, Jensen JS et al. Association of Mycoplasma genitalium with acute non-gonococcal urethritis in Russian men: a comparison with gonococcal and chlamydial urethritis. Int J STD AIDS 2009;20:234-7.

Vincelette J, Schirm J, Bogard M et al. Multicenter evaluation of the fully automated COBAS AMPLICOR PCR test for detection of Chlamydia trachomatis in urogenital specimens. J Clin Microbiol 1999;37:74-80. de Waaij DJ, Dubbink JH, Peters RPH et al. Comparison of GMT presto assay and Roche cobas $₫ 4800$ CT/NG assay for detection of Chlamydia trachomatis and Neisseria gonorrhoeae in dry swabs. $J$ Microbiol Methods 2015;118:70-4.

Wasserheit JN. Epidemiological synergy. Interrelationships between human immunodeficiency virus infection and other sexually transmitted diseases. Sex Transm Dis 1992;19:61-77.

World Health Organization (WHO). Sexually transmitted infections (STIs). WHO Media Centre, 2016. http://www.who.int/mediacentre/factshe ets/fs110/en/ (date last accessed, 12 June 2017).

Wirtz AL, Zelaya CE, Peryshkina A et al. Social and structural risks for HIV among migrant and immigrant men who have sex with men in Moscow, Russia: implications for prevention. AIDS Care 2014;26:38795.

Xiridou M, Vriend HJ, Lugner AK et al. Modelling the impact of chlamydia screening on the transmission of HIV among men who have sex with men. BMC Infect Dis 2013;13:436 
Chapter 3

Chlamydia trachomatis

serovar distributions

in Russian men and women:

a comparison with

Dutch serovar distributions 



\title{
Chlamydia trachomatis serovar distributions in Russian men and women: a comparison with Dutch serovar distributions
}

\author{
V. Smelov ${ }^{1,2}$, K.D. Quint ${ }^{3}$, J. Pleijster ${ }^{4}$, P.H.M. Savelkoul ${ }^{5}$, \\ K. Shalepo ${ }^{6}$, E. Shipitsyna ${ }^{6}$, M. Domeika ${ }^{7}$, A. Gorelov ${ }^{1}$, \\ A. Savicheva ${ }^{6}$, W.G.V. Quint ${ }^{3}$, H.J.C. de Vries ${ }^{8,9}$, \\ S. Ouburg ${ }^{4}$ and S.A. Morré ${ }^{4}$
}

Drugs Today (Barc). 2009 Nov;45 Suppl B:33-8.

${ }^{1}$ Faculty of Medicine, St. Petersburg State University, St. Petersburg, Russia; ${ }^{2}$ St. Petersburg State University Outpatient Clinic, St. Petersburg, Russia; ${ }^{3}$ DDL Diagnostic Laboratory, Voorburg, the Netherlands; ${ }^{4}$ Laboratory of Immunogenetics, Department of Pathology, VU University Medical Center, Amsterdam, the Netherlands; ${ }^{5}$ Medical Microbiology and Infection Prevention, VU University Medical Center, Amsterdam, the Netherlands; ${ }^{6}$ Laboratory of Microbiology, D.O. Ott Research Institute of Obstetrics and Gynecology, St. Petersburg, Russia; ${ }^{7}$ Department of Medical Sciences, Uppsala University, Uppsala, Sweden; ${ }^{8}$ STI Outpatient Clinic, Municipal Health Service, Amsterdam, the Netherlands; ${ }^{9}$ Department of Dermatology, Academic Medical Center, University of Amsterdam, the Netherlands. 


\section{Summary}

The data on serovar distributions of Chlamydia trachomatis - the most diagnosed sexually transmitted infection (STI) worldwide - are important for epidemiologic purposes and transmission studies but are completely lacking in Russia. The aim of the current study is to determine the serogroup and serovar distributions in Russian men and women and compare these data with Dutch serogroup and serovar distributions. In Russian men and women, serogroup B was the most prevalent (46\%), followed by the intermediate serogroup (I group; 33\%) and serogroup C (21\%). The distribution was comparable between men and women. The serogroup distribution was similar to the previously published distribution in Dutch cohorts. However, on a serovar level statistically very significant differences were observed, reaching up to $P<0.0001$. The serovars $B$ and $G / G a$ had higher prevalences compared with the reported Dutch prevalences, while serovars F, H, I/Ia, J and K had lower prevalences compared with the Dutch studies. In conclusion, this is the first report of

Russian C. trachomatis serovar/serogroup distributions. Serogroup B is the most prevalent, followed by serogroup I and serogroup $C$ with no statistical differences on the serogroup level. However, significant differences between Russia and the Netherlands were observed in the distribution of $C$. trachomatis serovars. 


\section{Introduction}

In Russia, reliable figures regarding incidence and prevalence of the sexually transmitted bacterium Chlamydia trachomatis infections remain highly limited. This is primarily the result of suboptimal diagnostics, case reporting and surveillance systems. However, in recent years, several DNA and RNA amplification systems (NAATs) have been developed and widely used in Russia in C. trachomatis diagnostics (1-3). Recently, the first prevalence figures have been published: $12.6 \%$ (56 of 446) in youth center attendees (4).

Dividing C. trachomatis into separate strains is a valuable tool for epidemiologic purposes and transmission studies. The $C$. trachomatis species is currently classified into 19 serovars: A, B, Ba, C, D, Da, E, F, G, Ga, H, I, Ia, J, K, L1, L2, L2a and L3. This classification is based on immunoepitope analysis of the major outer membrane protein (MOMP) with polyclonal and monoclonal anti- bodies (MABs). The MOMP is the immunodominant antigen of $C$. trachomatis and contains four variable domains (VDs) that are flanked and interspaced by five constant domains (CDs). Three of the variable domains (VD1, VD2 and VD4) are surface exposed and contain antigenic epitopes which are known at the nucleotide level (5).

In order to study the epidemiology and transmission of $C$. trachomatis infections, laboratory techniques for differentiating $C$. trachomatis serovars have been developed and include standard MOMP serotyping, restriction fragment length polymorphism (RFLP) analysis of the polymerase chain reaction (PCR)-amplified omp1 gene (encoding the MOMP protein) (68), and nucleotide sequencing of the omp1 gene. Recently we have developed a novel $C$. trachomatis amplification, detection and genotyping method (CT-DT assay) (9). The CT-DT detection step involves a DNA enzyme immunoassay (DEIA) using probes for the three Chlamydia serogroups (group B, C and Intermediate) and the cryptic plasmid, permitting sensitive detection of all 19 serovars. C. trachomatis-positive samples are analyzed by a nitrocellulose-based reverse hybridization assay (RHA) containing probes for the 19 different serovars, including probes for the three Chlamydia serogroups.

With this study we are the first to determine the serogroup and serovar distribution in Russian women and men. In addition, the obtained serogroups and serovars are compared with two independent large distributions assessed in the Netherlands. 


\section{Patients and methods}

\section{Russian cohort}

Samples were collected consecutively from January 2006 to January 2008, during which time 83 C. trachomatis-positive urethral samples were collected from men in St. Petersburg, Russia (34 from the D.0. Ott Research Institute of Obstetrics and Gynecology and 49 from St. Petersburg State University Outpatient Clinic). Ninety-eight cervical samples from women were included (88 from the D.O. Ott Research Institute of Obstetrics and Gynecology and 10 from St. Petersburg State University Outpatient Clinic).

C. trachomatis positivity was assessed by either culture or in-house NAATs test used in St. Petersburg, as described elsewhere (4) and C. trachomatis positivity was confirmed by plasmid-based PCR in Amsterdam (10).

\section{Amplification, detection and genotyping using the CT-DT assay}

C. trachomatis genotyping was determined in the Netherlands for all samples positive for C. trachomatis with an inhouse PCR, using the CT-DT detection and genotyping assay (9). The CT-DT amplification, detection and genotyping steps were performed exactly according to the manufacturer's instructions (Labo Biomedical Products BV, Rijswijk, the Netherlands).

Briefly, first the CT-DT amplification step was performed on extracted DNA to amplify all serovars available in GeneBank. This multiplex primer set generates an 89 bp amplicon of the cryptic plasmid and a 160/157 bp amplicon of the variable region 2 of the omp 1 gene.

Secondly, the $C$. trachomatis detection step was done to confirm the results detected with the in-house PCR. Reverse primers containing a biotin label at the 5' end enabled capture of the reverse strand onto streptavidin- coated plates. Captured amplimers were denatured by alkaline treatment, and detected by a defined cocktail of digoxigenin-labeled probes. Finally, all PCR products that proved positive with the $C$. trachomatis detection step were further analyzed with the CT-DT genotyping assay. The CT-DT genotyping assay is a reverse hybridization probe line blot (RHA) with a probe for the detection of the cryptic plasmid, 
and probes to detect the three different $C$. trachomatis serogroups (B, C and Intermediate) and 14 serovars (A, B/Ba, C, D/Da, E, F, G/Ga, H, I/Ia, J, K, L1, L2/L2a and L3). The different serovars are divided into serogroups based on phylogenetic mapping (Table I).

Each genotyping run contained a positive (serovar L2) and a negative control; $10 \%$ of the samples were retyped by the conventional PCR-based RFLP assay (6-8).

Table I. Serovar distribution into serogroups.

\begin{tabular}{|l|l|}
\hline \multicolumn{1}{|c|}{ Serogroup } & \multicolumn{1}{c|}{ Serovar } \\
\hline B & B, Ba, D, Da, E, L1, L2, L2a \\
\hline C & A, C, H. I. Ia, J, K, L3 \\
\hline I (Intermediate) & F, G, Ga \\
\hline
\end{tabular}

\section{Comparison with Dutch serovar distribution studies}

The obtained serovar and serogroup distribution in the Russian population studied were compared with two independent serovar distribution studies obtained in the Netherlands: A) 440 determined serovars published in 2000 (11), including 13 serovariants which were excluded for the comparison, leaving 108 serovar samples in men and 317 serovar samples in women for the comparison; B) 407 serovars determined in 2004 in a population with sexually transmitted disease (STD) at the Municipal Health Service in Amsterdam (12).

\section{Statistical analyses}

Serogroup and serovar distributions were compared between Russian men and women and between the Russian and Dutch cohorts, using chi-square statistics. $\mathrm{P}<0.05$ was considered statistically significant.

\section{Results}

\section{Russian serogroups and serovars}

Of the Russian cohort in seven samples (one female, six males), only plasmid DNA was detected, and these were excluded from the comparison analyses. Eight Russian samples 
(seven females, one male) contained double infections (three with E/'G/Ga'; one with D/'G/Ga'; one with E/undefined [serogroup I]; two with E/K; and one with F/K) and were excluded from the comparison analyses. This resulted in 90 women and 76 men for the final serovar distribution analyses. The distribution of the serogroups in Russian patients is shown in Table II.

E/undefined [serogroup I]; two with E/K; and one with F/K) and were excluded from the comparison analyses. This resulted in 90 women and 76 men for the final serovar distribution analyses. The distribution of the serogroups in Russian patients is shown in Table II.

In the Russian population studied, serogroup B was the most prevalent (46\%), followed by serogroup I (33\%) and serogroup C (21\%). The serovar distribution within the serogroups was comparable between men and women. A slight difference was observed in the distribution of serovars H (4 vs. 1\%) and K (6 vs. 11\%) (serogroup C) between men and women, respectively, although this did not reach statistical significance.

\section{Comparison of the Russian and Dutch serogroups and serovars}

The distribution of the serogroups in Russian patients was similar to the data on distribution in Dutch populations published in literature (Table II) $(11,12)$. When the serovar distributions were compared between the Russian cohort and the published Dutch cohorts, significant differences could be observed (Table II). In serogroup B, a significantly higher prevalence of serovar B was observed in the Russian cohort (5\%) compared with the Dutch cohorts (1\%) ( $<$ < 0.0001; OR: 12.06, 95\% CI: 3.5-41.1). In serogroup I, serovar F had a decreased prevalence ( 8 vs. $23 \%$ ), while serovar G/Ga (25 vs. 9\%) had an increased prevalence compared to the Dutch cohorts ( $<<0.0001$, OR: 7.4, 95\% CI: 3.8-14.5).

In serogroup $\mathrm{C}$, serovar $\mathrm{H}$ had a significantly lower prevalence compared with the study by Spaargaren et al. (12) ( $\mathrm{P}=0.0089$, OR: 0.25, 95\% CI: 0.09-0.72), while it was comparable to the study by Morré et al. (11) (Table II). The prevalence of serovar I/Ia was lower than in the Dutch cohorts (P < 0.0001, OR: 0.03, 95\% CI: 0.002-0.54). Prevalence of the serovars J and $\mathrm{K}$ were decreased in the Russian cohort compared with the study of 
Spaargaren et al. (12) (P = 0.0003, OR: 5.3, 95\% CI: 2.2-13.3; P = 0.0008, OR: 5.9, 95\% CI: 2.2-16.1, respectively), while they do not differ significantly from the study by Morré et al. (11).

\section{Discussion}

This is the first study to describe the C. trachomatis serovar distribution in a Russian population. The serogroup distribution in this cohort was as follows: B: 46\%, I: 33\% and

C: $21 \%$, with comparable distributions between males and females. The serogroup distribution was also comparable to that found worldwide (13-17), with serogroup B as the most prevalent serogroup. A slightly higher C. trachomatis prevalence was observed in St. Petersburg, Russia, compared with that reported in the Netherlands (6 vs. 2\%) (18). Although serogroup distribution was identical to reported distributions in Dutch populations, significant differences were observed in the serovar level distributions between these cohorts. A higher prevalence of serovars B and G/Ga was observed in this study compared with the published prevalences in Dutch cohorts $(11,12)$, while a lower prevalence of serovars F and I/Ia was observed. Serovars H, J and K had a lower prevalence when compared with the study by Spaargaren et al. (12), but were comparable to that of Morré et al. (11). Similar serovar distributions have been observed worldwide, with small differences depending on the studied region and study size (13-17).

The samples found to be positive in Russia were retested in the Netherlands and all were confirmed, showing the reliability of the $C$. trachomatis detection setting in St. Petersburg, Russia. When the $C$. trachomatis-positive samples were used for serovar typing, seven samples (3.9\%) were plasmid-positive only, but negative on the omp1 level. This can be explained by the fact that the omp 1 target is present only once per cell, while the plasmid target used to detect $C$. trachomatis is 10 times more present per cell. This makes the detection more sensitive compared with typing. Most likely, these seven samples were either low bacterial load samples and/or the DNA was partially degraded, making it impossible to type the serovars. Although the numbers were small, most of these plasmid-only infections were obtained from men (6/7). The new typing technique used (9) is more sensitive as compared with the PCR-based RFLP typing (6-8), which amplifies the complete omp 1 gene of $1.1 \mathrm{~kb}$, 
while the new technique only amplifies a small fragment, variable segment 2, ensuring high typing efficiency.

Table II. Serovar distribution in Russian patients divided into serovars and serogroups and by gender. Previously published results in Dutch cohorts $(11,12)$ are given for comparison

\begin{tabular}{|c|c|c|c|c|c|c|c|}
\hline \multirow{2}{*}{ Serovar } & \multicolumn{3}{|c|}{ This study } & \multirow{2}{*}{$\begin{array}{l}\text { Spaargarden et } \\
\text { al. } 2004(12)\end{array}$} & \multicolumn{3}{|c|}{ Morré et al. 2000 (11) } \\
\hline & $\begin{array}{c}\text { Women } \mathrm{n} \\
(\%)\end{array}$ & $\begin{array}{c}\text { Men n } \\
(\%)\end{array}$ & Total & & $\begin{array}{c}\text { Women n } \\
(\%)\end{array}$ & $\begin{array}{c}\text { Men n } \\
(\%)\end{array}$ & Total \\
\hline \multicolumn{8}{|l|}{ B serogroup } \\
\hline B & $\begin{array}{c}4 \\
(4.4)\end{array}$ & $\begin{array}{c}4 \\
(5.3)\end{array}$ & $\begin{array}{c}8 \\
(4.8)\end{array}$ & $\begin{array}{c}4 \\
(1.0)\end{array}$ & $\begin{array}{c}0 \\
(0.0)\end{array}$ & $\begin{array}{c}0 \\
(0.0)\end{array}$ & $\begin{array}{c}0 \\
(0.0)\end{array}$ \\
\hline $\mathrm{D} / \mathrm{D}-$ & $\begin{array}{c}9 \\
(10.0)\end{array}$ & $\begin{array}{c}5 \\
(6.6)\end{array}$ & $\begin{array}{c}14 \\
(8.4)\end{array}$ & $\begin{array}{c}50 \\
(12.3)\end{array}$ & $41(12.9)$ & $\begin{array}{c}12 \\
(10.8)\end{array}$ & $\begin{array}{c}53 \\
(12.4)\end{array}$ \\
\hline E & $31(34.4)$ & $\begin{array}{c}24 \\
(31.6)\end{array}$ & $\begin{array}{c}55 \\
(33.1)\end{array}$ & $\begin{array}{c}136 \\
(33.4)\end{array}$ & $130(41.0)$ & $\begin{array}{c}47 \\
(42.3)\end{array}$ & $\begin{array}{c}177 \\
(41.4)\end{array}$ \\
\hline Subtotal & $44(48.9)$ & $\begin{array}{c}33 \\
(43.4)\end{array}$ & $\begin{array}{c}77 \\
(46.4)\end{array}$ & $\begin{array}{c}190 \\
(46.7)\end{array}$ & $171(53.9)$ & $\begin{array}{c}59 \\
(53.2)\end{array}$ & $\begin{array}{c}230 \\
(53.7)\end{array}$ \\
\hline \multicolumn{8}{|c|}{ Intermediate serogroup } \\
\hline $\mathrm{F}$ & $\begin{array}{c}7 \\
(7.8)\end{array}$ & $\begin{array}{c}7 \\
(9.2)\end{array}$ & $\begin{array}{c}14 \\
(8.4)\end{array}$ & $\begin{array}{c}95 \\
(23.3)\end{array}$ & $72(22.7)$ & $\begin{array}{c}21 \\
(18.9)\end{array}$ & $\begin{array}{c}93 \\
(21.7)\end{array}$ \\
\hline $\mathrm{G} / \mathrm{Ga}$ & $23(25.6)$ & $\begin{array}{c}18 \\
(23.7)\end{array}$ & $\begin{array}{c}41 \\
(24.7)\end{array}$ & $\begin{array}{c}38 \\
(9.3)\end{array}$ & $24(7.6)$ & $\begin{array}{c}12 \\
(10.8)\end{array}$ & $36(8.4)$ \\
\hline Subtotal & $30(33.3)$ & $\begin{array}{c}25 \\
(32.9) \\
\end{array}$ & $\begin{array}{c}55 \\
(33.1) \\
\end{array}$ & $\begin{array}{c}133 \\
(32.7) \\
\end{array}$ & $96(30.3)$ & $\begin{array}{c}33 \\
(29.7) \\
\end{array}$ & $\begin{array}{c}129 \\
(30.1) \\
\end{array}$ \\
\hline \multicolumn{8}{|l|}{ C serogroup } \\
\hline $\mathrm{H}$ & $\begin{array}{c}4 \\
(4.4)\end{array}$ & $\begin{array}{c}1 \\
(1.3)\end{array}$ & $\begin{array}{c}5 \\
(3.0)\end{array}$ & $\begin{array}{c}34 \\
(8.4)\end{array}$ & $\begin{array}{c}9 \\
(3.4)\end{array}$ & $\begin{array}{c}7 \\
(6.3)\end{array}$ & $16(3.7)$ \\
\hline I/Ia & $\begin{array}{c}0 \\
(0.0)\end{array}$ & $\begin{array}{c}0 \\
(0.0)\end{array}$ & $\begin{array}{c}0 \\
(0.0)\end{array}$ & $\begin{array}{c}30 \\
(7.4)\end{array}$ & $11(3.5)$ & $\begin{array}{c}6 \\
(5.4)\end{array}$ & $17(4.0)$ \\
\hline $\mathrm{J}$ & $\begin{array}{c}7 \\
(7.8)\end{array}$ & $\begin{array}{c}9 \\
(11.8)\end{array}$ & $\begin{array}{c}16 \\
(9.6)\end{array}$ & $\begin{array}{c}12 \\
(2.9)\end{array}$ & $17(5.4)$ & $\begin{array}{c}2 \\
(1.8)\end{array}$ & $19(4.4)$ \\
\hline K & $\begin{array}{c}5 \\
(5.5) \\
\end{array}$ & $\begin{array}{c}8 \\
(10.5)\end{array}$ & $\begin{array}{c}13 \\
(7.8)\end{array}$ & $\begin{array}{c}8 \\
(2.0)\end{array}$ & $13(4.1)$ & $\begin{array}{c}4 \\
(3.6)\end{array}$ & $17(4.0)$ \\
\hline Subtotal & $16(17.8)$ & $\begin{array}{c}18 \\
(23.7)\end{array}$ & $34(20.5)$ & $\begin{array}{c}84 \\
(20.6)\end{array}$ & $50(15.8)$ & $\begin{array}{c}19 \\
(17.1)\end{array}$ & $\begin{array}{c}69 \\
(16.1)\end{array}$ \\
\hline Total & 90 & 76 & 166 & 407 & 317 & 111 & 428 \\
\hline
\end{tabular}

In the current study we found eight (4.4\%) double infections. These all included at least one serovar from the two most prevalent serogroups. This percentage of double infections 
is in the same range, although slightly higher as compared with previously reported double infections in the Netherlands (2\%) (11). In general, double infections were detected in 1-10\% of the infections, based on the population studied (high risk vs. low risk) and the sensitivity of the typing technique used (19-21). Remarkably, seven out of the eight double infections in this study were detected in women. When looking into detail to the Russian Intermediate serogroup containing the serovars $\mathrm{F}$ and $\mathrm{G} / \mathrm{Ga}$, and comparing them with the frequencies of these serovars in the Dutch Intermediate serogroup, one notices that they are exactly reverse: $7-9 \%$ vs. $21-24 \%$. This could potentially be a typing artefact. However, we retyped $10 \%$ of the samples by PCR-based RFLP (data not shown), and all F and G/Ga results between these two techniques were identical, ensuring reliable serovar allocation of the samples. This statistically significant difference has not been reported before, when comparing serovar distributions from country.

Future studies are needed to extend the number of isolates in these studies and cohorts with different risk profiles for infections. In addition, these epidemiologic studies on the spread of different serovars can be used in transmission studies and identifying specific sexual networks.

\section{Conclusions}

This is the first report of Russian C. trachomatis serovar/serogroup distributions. Serogroup B was found to be the most prevalent, followed by serogroup I and serogroup C. Significant differences were observed in the distribution of $C$. trachomatis serovars between Russia and the Netherlands.

\section{Acknowledgments}

This study was supported in part by a UNESCO-ASM International Travel Award and a EUSP Clinical Fellowship issued to V. Smelov in 2006 and 2007, respectively. This work was supported by the European Commission within the Sixth Framework Programme through the EpiGenChlamydia project (contract no. LSHG-CT-2007-037637). See www.EpiGenChlamydia.eu for more details. 


\section{Disclosure}

The authors have nothing to disclose.

\section{References}

1. Shipitsyna, E., Guschin, A., Maximova, A. et al. Comparison of microscopy, culture and in-house PCR and NASBA assays for diagnosis of Neisseria gonorrhoeae in Russia. APMIS 2008,116(2):133-8.

2. Shalepo, K., Savicheva, A., Shipitsyna, E., Unemo, M., Domeika, M. Diagnosis of Chlamydia trachomatis in Russia inhouse PCR assays may be effective but overall optimization and quality assurance are urgently needed. APMIS 2006, 114(7-8): 500-7.

3. Shipitsyna, E., Shalepo, K., Savicheva, A., Unemo, M., Domeika, M. Pooling samples: The key to sensitive, specific and cost-effective genetic diagnosis of Chlamydia trachomatis in low-resource countries. Acta Derm Venereol 2007, 87(2): 140-3.

4. Shipitsyna, E., Zolotoverkhaya, E., AgneStadling, I. et al. First evaluation of six nucleic acid amplification tests widely used in the diagnosis of Chlamydia trachomatis in Russia. J Eur Acad Dermatol Venereol 2009, 23(3): 268-76.

5. Yuan, Y., Zhang, Y.X., Watkins, N.G., Caldwell, H.D. Nucleotide and deduced amino acid sequences for the four variable domains of the major outer membrane proteins of the 15 Chlamydia trachomatis serovars. Infect Immun 1989, 57(4): 1040-9.

6. Molano, M., Meijer, C.J., Morré, S.A., Pol, R., van den Brule, A.J. Combination of PCR targeting the VD2 of omp1 and reverse line blot analysis for typing of urogenital Chlamydia trachomatis serovars in cervical scrape specimens. J Clin Microbiol 2004, 42(7): 2935-9.

7. Morré, S.A., Moes, R., Van Valkengoed, I., Boeke, J.P., van Eijk, J.T., Meijer, C.J., van den Brule, A.J. Genotyping of Chlamydia trachomatis in urine specimens will facilitate large epidemiological studies. $J$ Clin Microbiol 1998, 36(10): 3077-8.

8. Morré, S.A., Ossewaarde, J.M., Lan, J., van Doornum, G.J., Walboomers, J.M., MacLaren, D.M., Meijer, C.J., van den Brule, A.J. Serotyping and genotyping of genital Chlamydia trachomatis isolates reveal variants of serovars $\mathrm{Ba}, \mathrm{G}$, and $\mathrm{J}$ as confirmed by omp1 nucleotide sequence analysis. J Clin Microbiol 1998, 36(2): 345-51. 
9. Quint, K.D., van Doorn, L.J., Kleter, B. et al. A highly sensitive, multiplex broadspectrum PCR-DNA-enzyme immunoassay and reverse hybridization assay for rapid detection and identification of Chlamydia trachomatis serovars. J Mol Diagn 2007, 9(5): 631-8.

10. Morré, S.A., van Valkengoed, I.G., de Jong, A., Boeke, A.J., van Eijk, J.T., Meijer, C.J., van den Brule, A.J. Mailed, homeobtained urine specimens: A reliable screening approach for detecting asymptomatic Chlamydia trachomatis infections. J Clin Microbiol 1999, 37(4): 976-80.

11. Morré, S.A., Rozendaal, L., van Valkengoed, I.G. et al. Urogenital Chlamydia trachomatis serovars in men and women with a symptomatic or asymptomatic infection: An association with clinical manifestations? J Clin Microbiol 2000, 38(6): 2292-6.

12. Spaargaren, J., Verhaest, I., Mooij, S. et al. Analysis of Chlamydia trachomatis serovar distribution changes in the Netherlands (1986-2002). Sex Transm Infect 2004, 80(2): 151-2.

13. Bandea, C.I., Debattista, J., Joseph, K., Igietseme, J., Timms, P., Black, C.M. Chlamydia trachomatis serovars among strains isolated from members of rural indigenous communities and urban populations in Australia. J Clin Microbiol 2008, 46(1): 355-6.

14. Chen, X.S., Yin, Y.P., Mabey, D. et al.
Prevalence of Chlamydiatrachomatis infections among women from different settings in China: Implications for STD surveillance. Sex Transm Infect 2006, 82(4): 283-4.

15. Gao, X., Chen, X.S., Yin, Y.P. et al. Distribution study of Chlamydia trachomatis serovars among high-risk women in China performed using PCRrestriction fragment length polymorphism genotyping. J Clin Microbiol 2007, 45(4): 1185-9.

16. Petrovay, F., Balla, E., Nemeth, I., Gonczol, E. Genotyping of Chlamydia trachomatis from the endocervical specimens of high-risk women in Hungary. J Med Microbiol 2009, 58(Pt 6): 760-4.

17. Quint, K., Porras, C., Safaeian, M. et al. Evaluation of a novel PCR-based assay for detection and identification of Chlamydia trachomatis serovars in cervical specimens. J Clin Microbiol 2007, 45(12): 3986-91.

18. van Bergen, J., Gotz, H., Richardus, J.H., Hoebe, C., Broer, J., Coenen, T. Prevalence of urogenital Chlamydia trachomatis infections in the Netherlands suggests selective screening approaches. Results from the PILOT CT Population Study. Drugs Today (Barc) 2006, 42(Suppl. A): 25-33.

19. Batteiger, B.E., Lennington, W., Newhall, W.J., Katz, B.P., Morrison, H.T., Jones, R.B. Correlation of infecting serovar and local inflammation in genital chlamydial 
infections. J Infect Dis 1989, 160(2):

332-6.

20. Barnes, R.C., Suchland, R.J., Wang, S.P., Kuo, C.C., Stamm, W.E. Detection of multiple serovars of Chlamydia trachomatis in genital infections. J Infect Dis 1985,
152(5): 985-9.

21. Chungue, E., Soulier, J., Philippon, G., Wang, S.P. Immunotypes of Chlamydia trachomatis isolated from geni- tal tract specimens in Tahiti. Eur J Clin Microbiol Infect Dis 1994,13(5): 436-8. 


\section{Chapter 4}

Chlamydia trachomatis strain types

have diversified regionally and

globally with evidence for

recombination across geographic

divides 



\title{
Chlamydia trachomatis strain types have diversified regionally and globally with evidence for recombination across geographic divides
}

\author{
Vitaly Smelov ${ }^{1,2,3}$, Alison Vrbanac 4 , Eleanne F. van Ess ${ }^{5} \dagger$, Marlies Noz ${ }^{5}$, \\ Raymond Wan', Carina Eklund², Tyler Morgan', Lydia A. Shrier6 ${ }^{6}$, Blake \\ Sanders' ${ }^{4}$, Joakim Dillner ${ }^{2}$, Henry J. C. de Vries ${ }^{7,89}$, Servaas A. Morre ${ }^{5,10}$, and \\ Deborah Dean ${ }^{4,11,12^{*}}$
}

Front in Microbiol, in press

${ }^{1}$ International Agency for Research on Cancer, World Health Organization, Lyon, France, ${ }^{2}$ Karolinska Institute, Stockholm, Sweden, ${ }^{3}$ North-Western State Medical University named after I.I. Mechnikov, St. Petersburg, Russia, 4UCSF Benioff Children's Hospital Oakland Research Institute, Oakland, CA, United States, ${ }^{5}$ Laboratory of Immunogenetics, Department of Medical Microbiology and Infection Control, VU University Medical Center, Amsterdam, the Netherlands, 'Department of Pediatrics, Boston Children's Hospital, Boston, Massachusetts, United States, ${ }^{7}$ Center for Infection and Immunology Amsterdam (CINIMA), Academic Medical Center, 1105 AZ, Amsterdam, The Netherlands, ${ }^{8}$ Department of Dermatology, Academic Medical Center, 1105 AZ, Amsterdam, The Netherlands, 9STI Outpatient Clinic, Public Health Service of Amsterdam (GGD Amsterdam), 1018 WT, Amsterdam, The Netherlands, ${ }^{10}$ Institute of Public Health Genomics, Department of Genetics and Cell Biology, Research Institute GROW (School for Oncology \& Developmental Biology), Faculty of Health, Medicine \& Life Sciences, University of Maastricht, Maastricht, The Netherlands, ${ }^{11}$ Department of Bioengineering, University of California at Berkeley and University of California at San Francisco, CA, United States, ${ }^{12}$ Departments of Medicine and Pediatrics, UCSF, San Francisco, CA, United States; †Contributed equally to this work. 


\section{Abstract}

Chlamydia trachomatis $(C t)$ is the leading cause of bacterial sexually transmitted diseases (STD) worldwide. The Ct Multi Locus Sequence Typing (MLST) scheme is effective in differentiating strain types (ST), deciphering transmission patterns and treatment failure, and identifying recombinant strains. Here, we analyzed 323 reference and clinical samples, including 58 samples from Russia, an area that has not previously been represented in $C t$ typing schemes, to expand our knowledge of the global diversification of $C t$ STs. The 323 samples resolved into 84 unique STs, a 3.23 higher typing resolution compared to the gold standard single locus ompA genotyping. Our MLST scheme showed a high discriminatory index, $D$, of 0.98 (95\% CI 0.97-0.99) confirming the validity of this method for typing. Phylogenetic analyses revealed distinct branches for the phenotypic diseases of lymphogranuloma venereum, urethritis and cervicitis, and a sub-branch for ocular trachoma. Consistent with these findings, single nucleotide polymorphisms (SNP) were identified that significantly correlated with each phenotype. While the overall number of unique STs per region was comparable across geographies, the number of STs was greater for Russia with a significantly higher ST/sample ratio of 0.45 (95\% CI: 0.35-0.53) compared to Europe or the Americas ( $\mathrm{p}<0.009)$, which may reflect a higher level of sexual mixing with the introduction of STs from other regions and/or reassortment of alleles. Four STs were found to be significantly associated with a particular geographic region. ST23 [p=0.032 (95\% CI: 1-23)], ST34 [p=0.019 (95\% CI: 1.1-25)]; and ST19 [p=0.0004 (95\% CI: 1.7-34.7)] were significantly associated with The Netherlands compared to Russia or the Americas, while ST 30 [p=0.031 (95\% CI: 1.1-17.8)] was significantly associated with the Americas. ST19 was significantly associated with The Netherlands and Russia compared with the Americans $[\mathrm{p}=0.0004$ (95\% CI: 1.7-34.7) and $\mathrm{p}=0.0058$ (95\% CI: 1.5-34.6), respectively]. Additionally, recombinant strains were ubiquitous in the data set [106 (32.8\%)], although Europe had a significantly higher number than Russia or the Americas $(\mathrm{p}<0.04)$, the majority of which were from Amsterdam [43 (87.8\%) of 49)]. The higher number of recombinants in Europe indicates selective pressure and/or adaptive diversification that will require additional studies to elucidate. 


\section{Introduction}

The modern pathogenic Chlamydiaceae family has a rich evolutionary history, diverging from environmental Chlamydiales approximately seven million years ago (Horn et al., 2004). The human Chlamydiaceae spp. Chlamydia trachomatis $(C t)$ has infected human populations causing sexually transmitted diseases and the chronic ocular disease known as trachoma since the $27^{\text {th }}$ century BC (Perkins and Hill, 2013). Trachoma was initially described in China and in the Eber's Papyrus of Egypt, and subsequently spread to Europe during the Crusades (Perkins and Hill, 2013). While improvements in hygiene and sanitation have eliminated trachoma from many global populations, the disease is still endemic in many developing countries of Africa, Central and South America, the South Pacific and Asia in addition to aboriginal populations in Australia (Perkins and Hill, 2013). Presently, $C t$ is the leading cause of preventable blindness and bacterial sexually transmitted infections (STIs) worldwide (Rowley et al., 2012) with estimates of over 250 million trachoma cases and 110 million annual STI cases, according to the World Health Organization (WHO: STIs).

$C t$ has evolved to include 19 serological variants (serovars) based on antibody typing of the major outer membrane protein (MOMP) with over 60 ompA genotypes (Batteiger et al., 2014a; Dean and Millman, 1997; Isaksson et al., 2016; Peuchant et al., 2016; Schillinger et al., 2016), the gold standard typing technique for all Chlamydiaceae spp. The serovars are designated A through $\mathrm{K}, \mathrm{Ba}, \mathrm{Da}$, Ia, Ja, and $\mathrm{L}_{1-3}$, and $\mathrm{L}_{2}$ a while the ompA genotypes or strains are denoted by the same or by a number or letter after the conventional serovar name (e.g., D1; Ga) for new genotypes (Batteiger et al., 2014b). These strains are responsible for ocular, urogenital and rectal infections. Ocular infections include trachoma, a chronic ocular disease, and ophthalmia neonatorum (Darville, 2005), an infection acquired during passage through a $C t$ infected birth canal (WHO: STIs). Urogenital strains cause not only ocular infections, which usually present as unilateral conjunctivitis (Dean et al., 2008), but also can ascend from the endocervix to cause sequelae such as pelvic inflammatory disease, infertility and ectopic pregnancy (Baud et al., 2008; Blas et al., 2007; Mårdh, 2004). Rectal infections can progress to proctitis and inguinal syndrome (Sethi et al., 2009). While the later is caused primarily by the lymphogranuloma venereum strains (LGV) $\mathrm{L}_{1-3}, \mathrm{~L}_{2} \mathrm{a}, \mathrm{L}_{2} \mathrm{~b}$, and $\mathrm{L}_{2} \mathrm{c}$, the former 
can be caused by most $C t$ strains, although strains B, Ba and C are rarely detected in the urethra, endocervix or rectum (Danby et al., 2016; Labiran et al., 2016). Strain A is the only strain that is confined to the ocular mucosa (Dean, 2010).

Classification of $C t$ strains was conventionally performed by serotyping and more recently by ompA genotyping (Dean et al., 1992) since the organism is rarely cultured, a requirement for serotyping. Although $о m p A$ genotyping can be informative, the gene represents a mere $0.1 \%$ of the genome and is subject to immune selective pressure and recombination (Joseph et al., 2011, 2012). Finer, more holistic typing schemes are necessary to track recombination events, differentiate new and persistent infections (Götz et al., 2013), reinfection, transmission patterns and elucidate potential biomarkers. Three Multi Locus Sequence Typing (MLST) schemes have been developed for Ct (5-7), of which only two meet the MLST criteria of using strictly housekeeping genes (Dean et al., 2009; Pannekoek et al., 2008b). Our MLST scheme employs seven highly conserved housekeeping genes and successfully resolves reference and clinical Ct samples into LGV, trachoma, non-prevalent non-invasive urogenital, and prevalent non-invasive urogenital clonal complexes representing the respective diseases in addition to revealing evidence for recombination (Batteiger et al., 2014a; Dean et al., 2009).

Partial and whole genome sequencing (WGS) have added considerably to our knowledge of the diversity of $C t$ and evidence for recombination. We initially bioinformatically identified recombination within ompA (Millman et al., 2001) and then among partial genome sequences of trachoma and sexually transmitted strains involving ompA and polymorphic membrane proteins ( $\mathrm{pmp}$ ) (Gomes et al., 2004, 2006, 2007). In the first publication of comparative WGS of $C t$, we identified three major clades that were similar to the MLST disease-related clonal complexes with a subclade encompassing the trachoma strains within the non-prevalent non-invasive urogenital clade (Joseph et al., 2011). Subsequent WGS by ours and other groups have substantiated these phylogenetic groupings as well as the recombinogenic nature of $C t$ (Joseph et al., 2012; Harris et al., 2012; Seth-Smith et al., 2012; Hadfield et al., 2017). 
As whole genome sequencing remains cost-prohibitive for large sample sets and beyond the reach of most research laboratories, in this work, $323 \mathrm{Ct}$ reference and clinical samples from fifteen countries and five continents were analyzed by MLST to provide a more comprehensive analysis of the global diversification of $C t$ strain types. We included 60 new clinical samples from Amsterdam, The Netherlands, and eight from Boston, Massachusetts, USA, in addition to 58 from St. Petersburg, Russia, a region that had not previously been evaluated by MLST.

\section{Material and methods}

\section{Study populations and ethics}

Information on populations and ethics for samples collected previously are included in the publications by Dean et al. (2009) and Batteiger et al. (2014b). Russian women were enrolled in the original studies following verbal informed consent after approval by the Local Institutional Review Board at DO Ott Institute of Obstetrics and Gynecology and the Russian Academy of Medical Sciences (RAMS), St. Petersburg, Russia (Shipitsyna et al., 2007). The studies were additionally approved by the Department of Clinical Investigations and Intellectual Property, St. Petersburg Medical Academy of Postgraduate Studies (NorthWestern State Medical University named after I.I. Mechnikov since 2011), under the Federal Agency of Public Health and Social Development of Roszdrav, in accordance with the Declaration of Helsinki. For the 60 Dutch samples, each was obtained as previously described (Dean et al., 2009) according to the Declaration of Helsinki. The eight Boston samples were sent to Dr. Dean as de-identified samples with no trace to patient name and were not considered human subjects according to IRB at Children's Hospital Oakland Research Institute and NIH guidelines.

For the Russian samples, endocervical swabs were obtained consecutively from January 2006 to January 2008 in two university clinics in St. Petersburg, Russia, as described elsewhere (Smelov et al., 2009). To minimize the potential for low response from the enrolled women, samples were collected without obtaining personal information. After 
removal of any mucous with a cotton swab, a Dacron swab was inserted into the endocervix, rotated and placed in an empty $5 \mathrm{~mL}$ vials. Specimens were kept at $4^{\circ} \mathrm{C}$ (39으) for up to four days before they were shipped to the laboratory where they were stored at $4^{\circ} \mathrm{C}\left(39^{\circ} \mathrm{F}\right)$. Within 1 to 3 days (Shipitsyna et al., 2007) all samples were tested for the presence of $C t$ by commercial NAAT assays (Shalepo et al., 2006; Smelov et al., 2009). Additionally, either a conventional PCR (Lytech, Moscow, Russia) or a real-time PCR (Central Research Institute of Epidemiology, Moscow, Russia) were used. The results were confirmed in Amsterdam, the Netherlands by the commercial real-time PCR (TaqMan, Applied Biosystems, USA) (Morré et al., 1999; Smelov et al., 2009) and CE-IVD certificated Presto CT-NG Assays (Goffin Molecular Technologies, Beek, the Netherlands) (de Waaij et al., 2015).

\section{C. trachomatis reference and clinical samples}

A total of 323 reference and clinical isolates were analyzed that included 58 endocervical samples from St. Petersburg, 60 additional endocervical samples from Amsterdam and eight endocervical samples from Boston, Massachusetts; 265 were already in the MLST database (http://www.mlst.net) including the 20 reference strains: A/SA-1, A/HAR13, B/TW5/OT, Ba/Apache2, C/TW3/OT, D/UW3/Cx, Da/TW-448, E/Bour, F/IC-Cal3, G/UW57/Cx, H/UW4/Cx, I/UW12/Ur, Ia/UW202, J/UW36/Cx, Ja/UW92, K/UW36/Cx, L1/440, L2/434, $\mathrm{L}_{2 \mathrm{a}} / \mathrm{UW} 396, \mathrm{~L}_{3} / 404$.

\section{ompA Genotyping and MLST analysis}

Genomic DNA was purified from clinical isolates and were ompA genotyped as described previously (Dean et al., 2009; Batteiger et al., 2014b). Only the samples from St. Petersburg were provided as swabs; DNA was extracted and purified for these samples using our protocol as described in Joseph et al. (2014). MLST analysis examined seven housekeeping genes: $g l y A, m d h C, p d h A, y h b G, p y k F$, lysS, and leuS, with primers as described (Dean et al., 2009) (Supplementary Table 1). All seven housekeeping genes were amplified and sequenced as described (Batteiger et al., 2014a). A consensus sequence was created from the forward and reverse sequence. The genes for each of the St. Petersburg, Amsterdam and 
Boston samples were each concatenated and queried against the 265 samples in the MLST database in addition to including these samples in the database. Allelic numbers and STs were assigned based on this query as described previously (Batteiger et al., 2014a).

\section{Phylogenetic analysis and strain clustering}

Using the concatenated sequences, dataset strain clustering and Single Nucleotide Polymorphism (SNP) analyses were performed as described (Batteiger et al., 2014a). Briefly, this included visualizing clusters of related STs and non-related STs using eBURST (http://eburst.mlst.net) (Feil et al., 2004). Founder STs were identified by the highest number of single locus variants (SLV) branching from that particular ST (i.e., the clonal ancestor that diversifies into other STs). Clonal complexes generated by eBURST were defined as a group of STs separated by one SLV.

Phylogenetic trees were created by Maximum likelihood using the Symmetric+GI model, which provided the best fit for the data, in the R package phangorn (Schlep, 2010), to analyze the nucleotide sequence variation between the seven MLST loci for each ST. Tree nodes were verified with 1,000 bootstrap replicates. Alternative evolutionary pathways, such as horizontal gene transfer, were analyzed with SplitsTree (www.splitstree.org) using the splits decomposition method as described (Dean et al., 2009; Tamura et al., 2013). In addition, the sequence for each of the seven MLST loci for a sample were compared across the dataset and to the ompA genotype of the same sample to determine evidence for putative recombination.

\section{Statistical tests}

Fisher's exact test was performed in R (http://www.r-project.org) to test for significant region-specific ompA and ST clustering; a p-value of $<0.05$ was considered significant. Confidence intervals were determined based on the method of Clopper-Pearsson (Borkowf, 2006). Simpson's Diversity Index, $D$, was calculated for the MLST data as described (Hunter and Gaston, 1988; Simpson, 1949). A $D$ value of $\geq 0.95$ was considered ideal for molecular typing techniques (van Belkum et al., 2007). The ompA genotypes were excluded from the 
analysis. The Benjamin-Hochberg FDR method (Benjamini, 1995) was used to correct $p$ values for multiple comparisons.

Samples were classified as putative recombinants when the sequences of the seven gene sequences that comprise the ST or any of the seven genes were non-concordant with each other or with the ompA genotype of the same sample.

PROC FREQ in SAS was used to identify SNPs associated with disease phenotype and Haplotype as described previously (Dean et al., 2009). Levene's test evaluated the variance across the dataset of the 323 samples. The Classification Index was used to determine significance of each SNP with a disease phenotype where a $\mathrm{p}$ value of $<0.05$ was considered significant.

DnaSP v5.10 (Librado and Rozas, 2009) was used to calculate nucleotide (nt) and haplotype (hd) to determine the genetic diversity and differentiation for regional subgroups on the concatenated sequences of the seven MLST genes. DnaSP considers the frequency of variants (STs) present in a population and also genetic distances that separate these variants from each other. Genetic population differentiation between regional subgroups was assessed using the pairwise fixation index (Fst) in Arlequin v3.5 (Excoffier and Lischer, 2010) with significance testing by permutation.

\section{Results}

\section{Characteristics and geographic distribution of alleles}

The characteristics of the alleles for each gene locus are shown in Supplementary Table 2. The number of alleles varied by gene locus, ranging from seven to 18, as did the number of polymorphic sites. We determined the allele frequencies by geographic region for the 78 alleles (Table 1). Thirty-two (41\%) alleles were observed once. The highest number of unique alleles for a geographic region was in Western Europe at 16 alleles but the highest frequency was $43.3 \%$ for Russia, which was not statistically significant. 
Table 1. Allele frequencies by geographic region by locus.

\begin{tabular}{|c|c|c|c|c|c|c|c|}
\hline $\begin{array}{l}\text { Gene } \\
\text { locus }\end{array}$ & $\begin{array}{c}\text { No. } \\
\text { alleles }\end{array}$ & $\begin{array}{c}\text { Africa } \\
\mathrm{n}=21 \\
(\%)\end{array}$ & $\begin{array}{c}\text { Western } \\
\text { Europe } \\
n=109 \\
(\%)\end{array}$ & $\begin{array}{c}\text { Russia } \\
\mathrm{n}=58 \\
(\%)\end{array}$ & $\begin{array}{c}\text { Asia } \\
\mathrm{n}=13 \\
(\%)\end{array}$ & $\begin{array}{c}\text { Americas } \\
\mathrm{n}=122 \\
(\%)\end{array}$ & $\begin{array}{c}\text { Classificatio } \\
\mathrm{n} \text { index p } \\
\text { value }\end{array}$ \\
\hline glyA & 12 & $\begin{array}{l}1(14.29) \\
3(80.95) \\
6(4.76)\end{array}$ & $\begin{array}{l}1(12.84) \\
3(50.46) \\
4(0.92) \\
5(1.83) \\
6(32.11) \\
8(0.92) \\
9(0.92)\end{array}$ & $\begin{array}{l}3(62.07) \\
6(34.48) \\
10(1.72) \\
11(1.72)\end{array}$ & $\begin{array}{c}3 \\
(30.77) \\
\\
6(7.69) \\
7 \\
(61.54)\end{array}$ & $\begin{array}{l}1(7.37) \\
2(\mathbf{0 . 8 2}) \\
3(42.62) \\
6(48.36)\end{array}$ & $<.001$ \\
\hline$m d h C$ & 7 & $\begin{array}{c}1 \text { (14.29) } \\
3(76.19) \\
4(4.76) \\
5(4.76)\end{array}$ & $\begin{array}{l}1(11.93) \\
2(2.75) \\
3(70.64) \\
4(12.84) \\
6(1.83)\end{array}$ & $\begin{array}{l}3 \text { (63.79) } \\
4(34.48) \\
7 \text { (1.72) }\end{array}$ & $\begin{array}{c}3 \\
(100.00)\end{array}$ & $\begin{array}{l}1(8.19) \\
3(68.85) \\
4(22.95)\end{array}$ & $<.001$ \\
\hline$p d h A$ & 8 & $\begin{array}{l}1(4.76) \\
3(95.24)\end{array}$ & $\begin{array}{l}2(0.92) \\
3(91.74) \\
4(2.75) \\
5(3.67) \\
7(0.92)\end{array}$ & $\begin{array}{l}3(94.83) \\
5(3.45) \\
8(1.72)\end{array}$ & $3(100)$ & $\begin{array}{l}3(97.54) \\
5(1.64) \\
6(0.82)\end{array}$ & $<.001$ \\
\hline$y b h G$ & 11 & $\begin{array}{l}2(4.76) \\
6(80.96) \\
8(14.29)\end{array}$ & $\begin{array}{c}2(31.19) \\
3(0.92) \\
5(1.83) \\
6(48.62) \\
7(0.92) \\
8(15.60) \\
9(0.92)\end{array}$ & $\begin{array}{l}6(48.28) \\
9(5.17)\end{array}$ & $\begin{array}{c}1 \text { (7.69) } \\
\\
4(7.69) \\
5(7.69) \\
6 \\
(76.92)\end{array}$ & $\begin{array}{c}2(43.44) \\
3(0.82) \\
5(9.83) \\
6(37.70) \\
8(7.38)\end{array}$ & $<.001$ \\
\hline
\end{tabular}




\begin{tabular}{|c|c|c|c|c|c|c|c|}
\hline & & & & $11(1.72)$ & & $10(0.82)$ & \\
\hline pykF & 10 & $\begin{array}{l}1(14.29) \\
3(71.43) \\
6(9.52) \\
7(4.76)\end{array}$ & $\begin{array}{l}1(15.60) \\
\\
6(49.54) \\
7(33.03) \\
\mathbf{8}(\mathbf{0 . 9 2 )} \\
\mathbf{9}(\mathbf{0 . 9 2 )}\end{array}$ & $\begin{array}{l}6(53.45) \\
7(37.93) \\
10(\mathbf{8 . 6 2})\end{array}$ & $\begin{array}{c}3 \\
(92.31) \\
\\
7(7.69)\end{array}$ & $\begin{array}{l}1(8.20) \\
2(2.46) \\
4(\mathbf{0 . 8 2}) \\
\mathbf{5}(\mathbf{0 . 8 2}) \\
6(36.07) \\
7(51.64)\end{array}$ & $<.001$ \\
\hline lysS & 12 & $\begin{array}{l}4(23.81) \\
5(71.43) \\
7(\mathbf{4 . 7 6 )}\end{array}$ & $\begin{array}{l}1(6.42) \\
4(74.31) \\
8(18.35) \\
10(0.92)\end{array}$ & $\begin{array}{l}1(8.62) \\
4(74.14) \\
8(13.79) \\
11(1.72) \\
12(1.72)\end{array}$ & $\begin{array}{c}4(7.69) \\
5 \\
(30.77) \\
\mathbf{6} \\
(\mathbf{6 1 . 5 4 )}\end{array}$ & $\begin{array}{l}1(7.38) \\
2(0.82) \\
3(0.82) \\
4(73.77) \\
\\
8(14.75) \\
9(2.46)\end{array}$ & $<.001$ \\
\hline leusS & 18 & $\begin{array}{c}2(4.76) \\
3(4.76) \\
7(9.52) \\
9(66.67) \\
11 \\
(14.29)\end{array}$ & $\begin{array}{l}3(75.23) \\
4(0.92) \\
5(0.92) \\
6(3.67) \\
8(2.75) \\
11(15.60) \\
13(0.92)\end{array}$ & $\begin{array}{l}3(79.31) \\
6(8.62) \\
8(3.45) \\
\\
\\
14(1.72) \\
15(1.72) \\
16(1.72)\end{array}$ & $\begin{array}{c}2(7.69) \\
\\
\\
\\
\\
7 \\
(84.62) \\
\\
\\
10 \\
(7.69)\end{array}$ & $\begin{array}{c}1(2.46) \\
3(67.21) \\
6(5.74) \\
8(14.75) \\
9(0.82) \\
11(7.38) \\
12(1.64)\end{array}$ & $<.001$ \\
\hline
\end{tabular}




\begin{tabular}{|c|c|c|c|c|c|c|c|}
\hline & & & $\begin{array}{c}\mathbf{1 7}(\mathbf{1 . 7 2}) \\
\mathbf{1 8}(\mathbf{1 . 7 2})\end{array}$ & & & \\
\hline $\begin{array}{c}\text { No. } \\
\text { novel } \\
\text { alleles } \\
\text { per } \\
\text { region }\end{array}$ & & $3(12.5 \%)$ & $16(40 \%)$ & $\begin{array}{c}13 \\
(43.3 \%)\end{array}$ & $5(29.4)$ & 13 & \\
\hline $\begin{array}{c}\text { Total no. } \\
\text { alleles }\end{array}$ & 78 & 24 & 40 & 30 & $17 \%)$ & 36 & \\
\hline
\end{tabular}

*Numbers are arranged vertically for each locus to represent the individual alleles (e.g. glyA alleles are assigned $1,2,3,4,5,6,7 \ldots 12$ because there are 12 alleles for this locus). Alleles marked in boldface are specific for a single geographic region. $n$, number of samples.

\section{ST and $o m p A$ distributions}

For the 323 samples, 84 unique STs were identified (Supplementary Table 3). STs novel to the dataset were numbered consecutively in order of identification. Of those 84, 57 (67.9\%) were singletons, with a relatively even distribution by geographic region (excluding Asia and Africa where the sample sizes were very small) with a higher percentage of singletons in Europe that was not significantly different (Table 2; $\mathrm{p}=0.08$ ). Table 2 also shows that the percentage of unique STs per region was highly similar. However, the ST/sample ratio was significantly greater for Russian than for European and American samples ( $\mathrm{p}<0.009)$. There were also significant differences in the distribution of STs (Table 3). Dutch females $(n=79)$ were significantly more likely to be infected with ST23 (p=0.032; 95\% CI: 1-23) and ST34 ( $\mathrm{p}=0.02$; 95\% CI: 1.1-25) compared to Russian females $(\mathrm{n}=58)$ and with ST19 (p=0.0004; 95\% CI: 1.7-34.7) compared to American females ( $n=108)$. Supplementary Table 4 shows the distribution of STs by geographic region.

There were 26 ompA genotypes observed in the dataset resulting in a 3.23 lower resolution than for STs. Excluding the sexually transmitted disease (STDs) samples from South Africa, all samples available from Asia and Africa were from trachoma patients; 1 (7.1\%) of 14 was a urogenital Da ompA genotype (ST 37) in Asia while 1 (5.9\%) of 17 was a urogenital E genotype (ST 39) in Africa. 
Table 2. ST diversity and recombinants by geographic region.

\begin{tabular}{|l|c|c|c|c|c|c|}
\hline $\begin{array}{l}\text { Geographic } \\
\text { location }\end{array}$ & $\begin{array}{c}\text { No. of } \\
\text { Samples }\end{array}$ & $\begin{array}{c}\text { No. } \\
\text { of } \\
\text { ST's }\end{array}$ & $\begin{array}{c}\text { ST/sample } \\
\text { ratio (95\% CI) }\end{array}$ & $\begin{array}{c}\text { No. ST } \\
\text { Singletons } \\
\text { (\%) }\end{array}$ & $\begin{array}{c}\text { No. Novel } \\
\text { STs per } \\
\text { Region (\%) }\end{array}$ & $\begin{array}{c}\text { No. } \\
\text { Recombinant } \\
\text { Samples (\%) }\end{array}$ \\
\hline Europe & 109 & 28 & $\begin{array}{c}0.26 \\
(0.18-0.39)\end{array}$ & $17(61)$ & $19(68)$ & $49(45)^{* *}$ \\
\hline Americas & 122 & 34 & $\begin{array}{c}0.28 \\
(0.20-0.40)\end{array}$ & $16(47)$ & $24(71)$ & $28(23)$ \\
\hline Asia & 13 & 8 & $\begin{array}{c}0.57 \\
(0.48-0.66)\end{array}$ & $5(63)$ & $8(100)$ & $1(7.7)$ \\
\hline Africa & 21 & 7 & $\begin{array}{c}0.35 \\
(0.26-0.44)\end{array}$ & $5(71)$ & $5(71)$ & $8(38.1)$ \\
\hline Russia & 58 & 26 & $\begin{array}{c}0.45 * \\
(0.35-0.53)\end{array}$ & $14(54)$ & $18(69)$ & $20(34.5)$ \\
\hline Total & $\mathbf{3 2 3}$ & & & $\mathbf{5 7}$ & & $\mathbf{1 0 6}(\mathbf{3 2 . 8})$ \\
\hline
\end{tabular}

*Significantly increased compared to Europe and the Americas ( $\mathrm{p}<0.009)$; Asia and Africa were excluded due to small numbers; **Significantly increased compared to Russia and the Americas $(\mathrm{p}<0.04)$.

Table 3. Differences in ST distribution by geographic region.

\begin{tabular}{|l|c|l|}
\hline Regions of Comparison* & ST & Significance \\
\hline Netherlands vs Russia & 23 & $\mathrm{p}=0.03199$ (95\% CI: $1-23)$ \\
\hline Netherlands vs Russia & 34 & $\mathrm{p}=0.0188$ (95\% CI: $1.1-25)$ \\
\hline Netherlands vs Americas & 19 & $\mathrm{p}=0.000399$ (95\% CI: $1.7-34.7)$ \\
\hline Americas vs Netherlands & 39 & $\mathrm{p}=0.03127$ (95\% CI: $1.1-17.8)$ \\
\hline Russia vs Americas & 19 & $\mathrm{p}=0.005752$ (95\% CI: $1.5-34.6)$ \\
\hline
\end{tabular}

*Women were analyzed separately for the purposes of comparing similar cohorts

ompA genotype $\mathrm{E}(\mathrm{n}=72)$ was the most prevalent and associated with 18 STs with an ST to sample ratio of 0.25 (Supplementary Table 3). The distribution for the remaining ompA genotypes in descending order was G (38; 16 STs; ratio: 0.42); D (33; 16 STs; ratio: 0.48); F (30; 5 STs; ratio: 0.17); Ia (17; 4 STs; ratio: 0.25); K (15; 7 STs; ratio: 0.47); J (13; 9 STs; ratio: 0.69); B, H and I at 12 samples each (7, 6, \& 3 STs, respectively; ratios: $0.58,0.50, \& .25$, respectively); C (11: 5 STs; ratio: 0.45); A (9; 4 STs; ratio: 0.44); D2 and Ja at 4 samples each 
( 1 \& 3 STs, respectively; ratios: $0.25 \& 0.75$, respectively); Ba, D1, E6, F4 and Ia4 at 2 samples each (1 ST for each; ratio: 0.50 for each); and Da (1; 1 ST; ratio: 0.10 ).

The ompA distribution of urogenital strains varied across Europe, the Americas, and Russia. In Europe, ompA genotype D was significantly more prevalent than in other geographic regions $(\mathrm{p}=0.046)$ and more frequent than the globally prevalent genotype $\mathrm{E}$. In Russia, ompA genotype $G$ was significantly more prevalent than in all other regions ( $p=0.000023$ ). In the Americas, ompA genotype Ia was significantly more prevalent than the other regions $(\mathrm{p}=0.0013)$. In comparing female STD cohorts, Russian women were significantly more likely to be infected with $E$ and $G(p=0.00036$ and 0.026 , respectively) while Dutch women were significantly more likely to be infected with D and I $(p=0.026$ and 0.0022 , respectively).

Simpson's Discriminatory Index was 0.98 (95\% CI 0.97-0.99) for MLST and 0.70 (95\% CI 0.67-0.73).

Based on DnaSP, nucleotide diversity was lower in Russia ( $\mathrm{Pi}=0.00216)$ compared to the Netherlands $(\mathrm{Pi}=0.00321)$ and North America $(\mathrm{Pi}=0.00294)$ (Table 4). However, the Netherlands and North American datasets contained isolates from men and LGV samples. The phylogenetically disparate LGV samples appeared to contribute substantially to nucleotide diversity; nucleotide diversity dropped from 0.00250 to 0.00196 in Dutch women when the four LGV isolates were removed. When comparing non-LGV isolates from women in these regions, Russian women had the highest nucleotide diversity ( $\mathrm{Pi}=0.00216$ ), followed by North American women ( $\mathrm{Pi}=0.00210)$, and Dutch women ( $\mathrm{Pi}=0.00196)$.

Assessing population differentiation between regional subgroups by Fst revealed significant differences between most regional subgroup pairwise comparisons (Table 5). African and Asian subgroups exhibited high Fst values in all comparisons, indicating those regions were distinct from others in the dataset. This is not surprising given the small sample size and the fact that these samples are from two distinct trachoma populations. Though Western Europe was significantly different from all subgroups, the Russia and Americas subgroups were not significantly different by Fst. However, this could be attributed to the higher LGV representation in the Western European samples (15.5\%) in comparison to the 
American samples (7.3\%), and Russian samples (0\%). Concordantly, when LGV samples were removed from the Western European dataset, Western Europe was no longer significantly different from Russia (Table 5). When evaluating only women without LGV from the Netherlands, Russia, and North America, the Russian women were not significantly different from the American and Netherlands women (Supplementary Table 8).

Table 4. Nucleotide and haplotype diversity.

\begin{tabular}{|l|l|l|l|}
\hline Subgroup & $\mathbf{N}$ & Nucleotide Diversity(nt) & Haplotype Diversity(hd) \\
\hline Russia & 58 & $0.00216 \pm 0.00007$ & $0.917 \pm 0.023$ \\
\hline Netherlands & 79 & $0.00321 \pm 0.00030$ & $0.879 \pm 0.020$ \\
\hline North America & 116 & $0.00294 \pm 0.00023$ & $0.926 \pm 0.012$ \\
\hline $\begin{array}{l}\text { North American } \\
\text { Women }\end{array}$ & 66 & $0.00210 \pm 0.00009$ & $0.925 \pm 0.016$ \\
\hline $\begin{array}{l}\text { Netherlands } \\
\text { Women }\end{array}$ & 72 & $0.00250 \pm 0.00026$ & $0.863 \pm 0.024$ \\
\hline $\begin{array}{l}\text { Netherlands } \\
\text { Women non-LGV }\end{array}$ & 68 & $0.00196 \pm 0.00011$ & $0.846 \pm 0.026$ \\
\hline
\end{tabular}

Table 5. Pairwise Population Differentiation (Fst) for Regional Subgroups.

\begin{tabular}{|c|c|c|c|c|c|c|c|}
\hline & Africa & Asia & Americas & Russia & $\begin{array}{c}\text { Western } \\
\text { Europe }\end{array}$ & $\begin{array}{c}\text { Western } \\
\text { Europe } \\
\text { non-LGV }\end{array}$ & $\begin{array}{c}\text { Americas } \\
\text { non-LGV }\end{array}$ \\
\hline Africa & & $0.23421^{*}$ & $0.27401^{*}$ & $0.33802^{*}$ & $0.17265^{*}$ & & \\
\hline Asia & & & $0.36715^{*}$ & $0.44728^{*}$ & $0.29367^{*}$ & & \\
\hline Americas & & & & $0.01482 \mathrm{~ns}$ & $0.02892^{*}$ & & \\
\hline Russia & & & & & $0.05425^{*}$ & $\begin{array}{l}0.00305 \\
\text { ns }\end{array}$ & $\begin{array}{l}0.00884 \\
\text { ns }\end{array}$ \\
\hline $\begin{array}{l}\text { Western } \\
\text { Europe }\end{array}$ & & & & & & & \\
\hline $\begin{array}{c}\text { Western } \\
\text { Europe } \\
\text { non-LGV }\end{array}$ & & & & & & & $0.02627^{*}$ \\
\hline $\begin{array}{l}\text { Americas } \\
\text { non-LGV }\end{array}$ & & & & & & & \\
\hline
\end{tabular}

${ }^{*} \mathrm{p}<0.05$ by permutation test $(\mathrm{n}=110)$ 


\section{Phylogenetic relationships and evidence for recombination}

The phylogenetic relationships were initially evaluated by eBURST, which revealed four clonal clusters (CC) similar to what we reported previously (Figure 1) (Batteiger et al., 2014a; Dean et al., 2009) but with the addition of an LGV cluster. These included CC-A encompassing trachoma STs, CC-B with non-invasive, non-prevalent urogenital STs, CC-C with non-invasive prevalent STs and CC-D that included LGV strains. The predicted founders were ST19, ST23, ST34 and ST39 (Figure 1; Supplementary Table 5). The 57 singleton STs are denoted by a gray circle alone or within a colored circle, representing a specific geographic region, but were not associated with any specific region.

The tree (Figure 2) revealed ST branches similar to the eBURST clusters; both had branches or clusters for the disease phenotypic groups of LGV, noninvasive prevalent urogenital, and noninvasive nonprevalent urogenital STs. However, the trachoma STs formed a subgroup of the noninvasive nonprevalent urogenital branch.

In addition, within disease groups, STs branched from central nodes by geographic region. These nodes contained, in general, large numbers of STs from diverse locations. For example, the founders ST19, ST23, ST34 and ST39 located at nodes in the tree contain STs from Europe, Russia and the Americas. The amino acid tree showed a similar phylogeny (Supplementary Figure 1).

The Splitstree decomposition tree revealed evidence for a network structure consistent with homologous recombination (Figure 3). This was demonstrated by the interconnecting networks specifically among the ST founders ST19, ST23, ST34 and ST39 and other STs on the network in addition to the canonical evolutionary pathway shown in the tree (Figure 2). Supplemental Figure 2 shows the amino acid tree.

The Splitstree data are consistent with findings in the MLST and ompA genotyping data. Samples were classified as recombinant when the sequences of the seven genes that determine the ST were non-concordant with each other or with the seven gene sequences of the $C t$ genotype associated with the ompA genotype (Table 6), denoted in bold in Supplementary Table 3. There was no evidence of any recombination among the seven ST genes for any sample, although this would conceivably be possible. 
Table 6. C. trachomatis recombinant samples in the dataset.

\begin{tabular}{|c|c|c|c|c|c|}
\hline ST & $\begin{array}{l}\text { No. of } \\
\text { samples } \\
\text { for ST }\end{array}$ & $\begin{array}{l}\text { ompA genotype } \\
\text { that matches ST } \\
\text { sequences }\end{array}$ & $\begin{array}{l}\text { Additional } \\
\text { ompA } \\
\text { genotypes for } \\
\text { ST }\end{array}$ & $\begin{array}{l}\text { No. of } \\
\text { Recombinants } \\
(\%)^{*}\end{array}$ & $\begin{array}{l}\text { Geographic } \\
\text { Region }\end{array}$ \\
\hline 2 & 1 & D & none & $1(100)$ & Americas \\
\hline 3 & 1 & $\mathrm{H}$ & none & $1(100)$ & Americas \\
\hline 8 & 1 & $\mathrm{~K}$ & none & $1(100)$ & Americas \\
\hline 12 & 12 & $\mathrm{~A}$ & $\mathrm{~B}, \mathrm{Ba}$ & $6(50)$ & Tanzania \\
\hline 15 & 12 & $\mathrm{~K}$ & $J$ & $5(42)$ & $\begin{array}{l}\text { Americas, } \\
\text { Russia }\end{array}$ \\
\hline 16 & 1 & $\mathrm{~J}$ & none & $1(100)$ & Americas \\
\hline 17 & 1 & E & none & $1(100)$ & Americas \\
\hline 19 & 40 & G & B, D, E, H, I, J, K & $25(62.5)$ & $\begin{array}{l}\text { Americas, } \\
\text { Europe, Russia }\end{array}$ \\
\hline 20 & 1 & $\mathrm{D}$ & none & $1(100)$ & Europe \\
\hline 23 & 32 & Ia & $\begin{array}{l}\text { A, B, D, G, H, I, J, } \\
\text { K }\end{array}$ & $17(53)$ & $\begin{array}{l}\text { Americas, } \\
\text { Europe, Russia }\end{array}$ \\
\hline 26 & 1 & G & none & $1(100)$ & Europe \\
\hline 34 & 38 & $\mathrm{~F}$ & D, E, J, Ja & $17(45)$ & $\begin{array}{l}\text { Americas, } \\
\text { Europe }\end{array}$ \\
\hline 37 & 1 & $\mathrm{Da}$ & none & $1(100)$ & Asia \\
\hline 39 & 45 & E & $\mathrm{D}, \mathrm{G}$ & $2(4.4)$ & $\begin{array}{l}\text { Americas, } \\
\text { Russia }\end{array}$ \\
\hline 41 & 1 & $\mathrm{Ja}$ & none & 1 (100) & Americas \\
\hline 45 & 8 & $\mathrm{~F}$ & $\mathrm{D}, \mathrm{E}$ & $5(62.5)$ & $\begin{array}{l}\text { Americas, } \\
\text { Europe, Russia }\end{array}$ \\
\hline 46 & 9 & $\mathrm{E}$ & $\mathrm{D}$ & $1(11)$ & Europe \\
\hline 49 & 1 & $\mathrm{~K}$ & none & $1(100)$ & Europe \\
\hline 50 & 1 & $\mathrm{~B}$ & none & $1(100)$ & Africa \\
\hline 53 & 1 & A & none & $1(100)$ & Africa \\
\hline 60 & 1 & $\mathrm{D}$ & none & $1(100)$ & Europe \\
\hline 62 & 1 & $\mathrm{D}$ & none & $1(100)$ & Europe \\
\hline 65 & 1 & $\mathrm{~K}$ & none & 1 (100) & Russia \\
\hline 66 & 1 & B & none & $1(100)$ & Russia \\
\hline 68 & 2 & $B \& G$ & B \& G & $2(100)$ & Russia \\
\hline 69 & 1 & $\mathrm{~J}$ & none & $1(100)$ & Russia \\
\hline
\end{tabular}




\begin{tabular}{|l|l|l|l|l|l|}
\hline 71 & 1 & E & none & $1(100)$ & Russia \\
\hline 72 & 1 & D & none & $1(100)$ & Russia \\
\hline 73 & 1 & J & none & $1(100)$ & Americas \\
\hline 74 & 1 & G & none & $1(100)$ & Russia \\
\hline 78 & 1 & D & none & $1(100)$ & Russia \\
\hline 79 & 2 & D \& Da & D \& Da & $2(100)$ & Russia \\
\hline 84 & 1 & K & none & $1(100)$ & Americas \\
\hline
\end{tabular}

*106 (32.8\%) samples were recombinants among the entire database of 323

A total of 105 (32.5\%) samples were considered putative recombinants. Excluding Asia and Africa where the sample sizes were small, Europe had a significantly higher number of recombinants than Russia and the Americas ( $\mathrm{p}<0.04$ ) (Table 2), where, of the 109 samples, 49 were recombinant with 43 (87.8\%) from the Netherlands. While $o m p A$ genotypes were generally consistent across samples of the same ST, many cases of recombinant strains were observed. For example, ST19 $(\mathrm{n}=40)$ was primarily associated with ompA genotype G (37.5\%) but eight different ompA genotypes (B, D, E, G, H, I, J, K) were also associated with this ST. The majority of these samples were from St. Petersburg and Amsterdam (Supplementary Table 3). ST23 (n=32) was also associated with eight ompA genotypes (B, D, G, H, I, Ia, J, K) but the most frequent was Ia (47\%). In contrast, the most geographically prevalent ST was ST39 $(n=45)$ where 95\% were associated with ompA genotypes E. There were also 24 singletons that were recombinants (Table 6).

Table 7 shows the ompA genotype, ST and allelic SNPs, if present, associated with each of the eight Boston samples added to the dataset. Under the column denoted MLST are the $C t$ strain types to which the sequences of the seven MLST genes are identical. For example, sample J/259b has four SNPs that are different from the sequences of the seven genes for reference and clinical J strains in the database. These SNPs are identical to the sequences of strains $\mathrm{G}$ and $\mathrm{K}$, which suggests that this sample is a recombinant between $\mathrm{J}$ and $\mathrm{G}$ or $\mathrm{K}$ strains. Another example is sample D/256b; the ompA genotype is D but the MLST sequences of the seven genes are identical to reference and clinical F strains in the database. Therefore, 
it is a recombinant between D and F. Five (62.5\%) of the eight Boston samples were putative recombinants. Supplementary Table 5 shows similar data for the 60 new samples from Amsterdam. For the Amsterdam samples, 43 (54.4\%) of 79 samples were recombinants. Likewise, Supplementary Table 6 represents the data from St. Petersburg where 20 (34.5\%) of 58 samples were recombinants.

Table 7: Evidence for recombination among the Boston, Massachusetts, C. trachomatis samples.

\begin{tabular}{|c|c|c|c|c|c|}
\hline Sample & ompA & ST sequence & ST & \multicolumn{2}{|c|}{ Location of allelic SNPs } \\
\hline $\mathrm{J} / 253 \mathrm{~b}$ & $\mathbf{J}$ & G or $\mathrm{K}$ & $15(G / K)$ & $\begin{array}{l}\text { G: pdhA: } 339 \mathrm{C} \rightarrow \mathrm{T} \\
\text { lysS: } 34 \mathrm{~A} \rightarrow \mathrm{G}\end{array}$ & $\begin{array}{l}\mathrm{K}: \text { pykF: } 40 \mathrm{G} \rightarrow \mathrm{A} \\
\text { lysS: } 34 \mathrm{~A} \rightarrow \mathrm{G}\end{array}$ \\
\hline $\mathrm{Ia} / 258 \mathrm{~b}$ & Ia & Ia & 23 (Ia) & & \\
\hline $\mathrm{F} / 255 \mathrm{~b}$ & $\mathrm{~F}$ & $\mathrm{~F}$ & $34(\mathrm{~F})$ & & \\
\hline $\mathrm{D} / 256 \mathrm{~b}$ & D & $\mathbf{F}$ & 34 (F) & & \\
\hline $\mathrm{D} / 257 \mathrm{~b}$ & D & $\mathbf{E}$ & 39 (E) & & \\
\hline $\mathrm{E} / 260 \mathrm{~b}$ & $\mathrm{E}$ & $\mathrm{E}$ & $39(\mathrm{E})$ & & \\
\hline $\mathrm{J} / 259 \mathrm{~b}$ & $\mathbf{J}$ & G or $\mathbf{K}$ & $73(G / K)$ & $\begin{array}{l}\text { G: } p d h A: 339 \mathrm{C} \rightarrow \mathrm{T} \\
\text { yhbG: } 433 \mathrm{G} \rightarrow \mathrm{C} \\
\text { lysS: } 34 \mathrm{~A} \rightarrow \mathrm{G} \\
\text { leuS: } 282 \mathrm{~T} \rightarrow \mathrm{C}\end{array}$ & $\begin{array}{l}\text { K: } y h b G: 433 \mathrm{G} \rightarrow \mathrm{C} \\
\text { pykF: } 40 \mathrm{G} \rightarrow \mathrm{A} \\
\text { lysS: } 34 \mathrm{~A} \rightarrow \mathrm{G} \\
\text { leuS: } 282 \mathrm{~T} \rightarrow \mathrm{C}\end{array}$ \\
\hline $\mathrm{K} / 254 \mathrm{~b}$ & $\mathbf{K}$ & $\mathbf{F}$ & 84 (F) & & \\
\hline
\end{tabular}

Note: Bold denotes putative recombinant

${ }^{*}$ The seven ST genes of the sample have the highest homology to the seven genes of the strain that has the ompA genotype denoted in the column (e.g., for sample D/256b that has a D ompA genotype, the seven ST genes were identical to the seven genes of F strains in the database where the ompA genotype was also $\mathrm{F}$ for those strains).

\section{Disease phenotypes are associated with specific Single Nucleotide Polymorphisms (SNPs)}

Table 8 shows the SNPs that are specific for each Haplotype and disease phenotype group. These groups include invasive urogenital disease caused by LGV strains (Haplotype 1), noninvasive urogenital disease group that includes the most prevalent worldwide strains 
including D, Da, E, and F (Haplotype 2), and trachoma caused by ocular A, B, Ba and C strains (Haplotype 3).

Table 8. Single nucleotide polymorphisms (SNP) correlate with haplotype and disease phenotype.

\begin{tabular}{|c|c|c|c|c|}
\hline $\begin{array}{l}\text { Gene } \\
\text { Locus }\end{array}$ & $\begin{array}{l}\text { No. of } \\
\text { SNPs } \\
\text { per } \\
\text { locus }\end{array}$ & $\begin{array}{c}\text { Haplotype } 1 \\
\text { All clinical and } \\
\text { reference invasive } \\
\text { LGV strains }\end{array}$ & $\begin{array}{c}\text { Haplotype } 2 \\
\text { Prevalent reference and } \\
\text { clinical Da, E, F, and Ja strains } \\
\text { (except clinical D/83s, D84s, } \\
\text { D2s, D/EC, D/LC, D/SotonD5, } \\
\text { D/SotonD6, D43nl, D/202nl, } \\
\text { D/203nl, D/204nl, D/205nl, } \\
\text { D/206nl, D/207nl, E87e, and } \\
\text { reference D/UW3/Cx) }\end{array}$ & $\begin{array}{c}\text { Haplotype } 3 \\
\text { All reference and } \\
\text { clinical trachoma } \\
\text { A, B, Ba and C } \\
\text { strains (except } \\
\text { reference strain } \\
\text { A/Sa-1 and strain } \\
\text { B/Jali20) }\end{array}$ \\
\hline & & $\begin{array}{c}\text { Disease } \\
\text { Phenotype: LGV* }\end{array}$ & $\begin{array}{c}\text { Disease Phenotype: } \\
\text { urogenital noninvasive* }\end{array}$ & $\begin{array}{c}\text { Disease } \\
\text { Phenotype: } \\
\text { trachoma* }\end{array}$ \\
\hline glyA & $1-7$ & & & \\
\hline$f m d h$ & $1-5$ & & & \\
\hline$p d h A$ & $1-6$ & & & \\
\hline$y h b G$ & $1-21$ & $\begin{array}{r}\text { SNPs } 2-6 \\
8-12 \\
16\end{array}$ & $\begin{array}{r}\text { SNPS } 15 \\
18 \\
20\end{array}$ & \\
\hline pykF & $1-9$ & & $\begin{array}{r}\text { SNPs } 6 \\
7\end{array}$ & SNP 3 \\
\hline lysS & $1-11$ & & & \\
\hline leuS & $1-12$ & $\begin{array}{r}\text { SNPs } 1 \\
5 \\
11 \\
\end{array}$ & & SNP 3 \\
\hline Total & 71 & 14 & 5 & 2 \\
\hline
\end{tabular}

NOTE: LGV, lymphogranuloma venereum; ${ }^{*} \mathrm{p}<0.01$

The non-invasive group includes clinical Ja strains that are recombinants of $\mathrm{E}$ and $\mathrm{F}$ strains. There are 14 SNPs that are specific for the LGV disease group, and each SNP independently identifies this group and Haplotype. The same is true for the non-invasive 
disease group. However, the two SNPs for the trachoma group together are specific for this group and Haplotype 3. Based on the Classification Index, the SNPs were not uniformly distributed.

\section{Discussion}

The evolution of straining-typing techniques for bacteria have progressed from identifying variations in gel electrophoresis patterns and melt curve analyses to sequencing single pathogen-specific genes and MLST. While typing based on WGS would be ideal, this remains out of reach given the current expense and lack, in general, of sufficient DNA from clinical samples. However, it should be mentioned that we and others have been developing techniques to enrich DNA recovery directly from urogenital and ocular patient sample types with some success (Seth-Smith et al., 2012; Joseph et al., 2014; Hadfield et al., 2017). OmpA genotyping remains widely used among Chlamydia investigators for molecular epidemiologic and comparative studies of strains between STD and trachoma populations. However, ompA encodes for the MOMP, which is under immune selection. MLST offers a more robust typing scheme by employing 6 to 8 housekeeping genes as relatively immutable signatures for strain typing (Dean et al., 2009; Maiden et al., 1998) and has become an important tool for studying both the epidemiology and evolution of human pathogens (Urwin and Maiden, 2003), including Ct.

In this study, we included 58 samples from Russia and eight from Boston, regions that have not previously been represented in $C t$ typing schemes. The 323 reference and clinical samples resolved into 84 STs, representing a 3.23 higher typing resolution over ompA genotyping consistent with previous studies (Batteiger et al., 2014b; Dean et al., 2009; Gravningen et al., 2012; Herrmann et al., 2015). The high discriminatory index $D$ of 0.98 (95\% CI 0.97-0.99) and narrow CI for our MLST scheme confirms the validity of this typing method.

We noted an overall high rate of novel STs (67.9\%), which may be expected because entire populations were not sampled and the numbers are small for some areas such as Asia and Africa. For example, there were 109 samples from Europe, representing six different countries, and 19 (68\%) of the 28 STs were novel. Our findings are similar to other studies 
in Europe where the rates for novel STs were 62\% among high school students in Norway (Gravningen et al., 2012), 65\% among Tunisian sex workers (Gharsallah et al., 2016) and $62 \%$ among young adults in Amsterdam (Versteeg et al., 2015). Additional novel STs are likely to be identified as new regions undergo MLST. Indeed in Russia, of the 26 STs that contained Russian samples, 18 (69\%) were novel.

A significantly higher ST to sample ratio of 0.45 was identified for Russian compared to European and American samples $(\mathrm{p}<0.009)$. This was not explained by the number of STs unique to a region as the percentages were relatively uniform across the geographies (Table 2). However, Russian women had the highest nucleotide diversity ( $\mathrm{Pi}=0.00216$ ), followed by North American women ( $\mathrm{Pi}=0.00210)$, and Dutch women ( $\mathrm{Pi}=0.00196)$, excluding LGV strains that are present only in the female Dutch population and would therefore skew the data. There are no males in the Russian dataset and therefore only women were evaluated here for the three locals. However, when assessing population differentiation for women from the Netherlands, Russia, and North America, excluding those with LGV, there were no significant differences (Supplemental Table 8). A larger sample size for each group would likely provide better resolution of the data. The increased sample ratio for Russia may reflect sexual mixing among the Russian STD cohort with the introduction of STs from other regions or reassortment of existing alleles. Of the 30 alleles present in Russia, 23 (76.7\%) were found in other geographic regions, supporting the geographic influx of STs. Reassortment of alleles that generate new STs is also possible given the higher frequency of novel alleles in Russia at $43.3 \%$. It has been shown that recombinational replacements are the major contributors to clonal diversity in contrast to point mutations among bacteria (Spratt et al., 2001). In support of our hypothesis, Hadfield et al. (2017) has shown that Ct evolves within genomic 'ecotypes' but also outside of these niches via recombination, consistent with prior genomic studies (Joseph et al., 2012; Harris et al., 2012). However, without a larger sample size from St. Petersburg, the relative overall diversity of STs will remain unknown, and we can only speculate as to the degree of reassortment based on the alleles comprising the STs that represent only the currently sampled cohort of women in Russia. 
Excluding singleton STs, STs 23 and 34 were significantly associated with female STD patients in Amsterdam. We had previously noted that ompA genotyping is valuable as a separate adjunctive typing method along with MLST as it allows comparison with strains typed only by ompA and also can provide evidence for transmission and treatment efficacy as well as putative recombination (Batteiger et al., 2014b). But ompA should not be included as one of the genes in the MLST scheme because it is under immune selection (Dean et al., 2009; Maiden et al., 1998). We performed ompA genotyping on all samples in the database and, for ST23, the samples comprised Ia, B, D, G, H, I, J and K genotypes while for ST34 they included genotypes F, D, D2, E, J and Ja (Supplemental Table 3). The high number of ompA genotypes for these two STs suggests a high rate of recombination. For example, the sequences of the seven MLST genes matched those of reference strain Ia/UW202 for $47 \%$ of the ST23 samples where the ompA genotype was also Ia. However, the remaining samples that also matched the seven MLST Ia/UW202 sequences had B, D, G, H, I, J and K ompA genotypes, indicating a mismatch between the MLST and ompA sequences, providing evidence for recombination (Supplemental Table 3). Similarly, STs such as 15, 19, and 34 had numerous samples, some of which were putative recombinants. These findings are supported by partial and WGSs where ompA has been shown to be involved in frequent exchange and is considered a hotspot for recombination (Gomes et al., 2007; Joseph et al., 2012; Harris et al., 2012). For example, phylogenetic analyses indicate clustering of ompA Ja genotypes, which are uncommon, with highly prevalent ompA D, E and F genotypes (similar to ST34) where hotspots of recombination were noted in ompA and pmpEFGH genomic regions (Gomes et al., 2007; Joseph et al., 2012). Clusters of ompA D genotypes with less prevalent strains G, Ia and J, similar to our strains in ST23, have also been noted (Harris et al., 2012). In a recent study, ompA Ba and C trachoma strains isolated from Australian Aborigines were found to cluster with urogenital D, Da, E and F strains with hotspots also involving ompA and pmpEFGH (Andersson et al., 2015). Of course, with WGS, many additional genes have been found to be involved in recombination (Joseph et al., 2012; Harris et al., 2012; Hadfield et al., 2017). 
To confirm putative recombinants, we had described that the sequences of the seven MLST genes were individually aligned to the respective gene for all samples in the database and compared these results to the ompA genotype of the same sample. For example, Table 7 shows the five putative recombinants among the eight Boston samples. Sample D/256b had an ompA genotype of D but the seven MLST sequences were an exact match to the seven sequences of $\mathrm{F}$. In some cases, one or more of the seven genes matched two different strains as was the case for samples $\mathrm{J} / 253 \mathrm{~b}$ and $\mathrm{J} / 259 \mathrm{~b}$. Other examples of recombinants are shown in Supplemental Tables 6 and $\mathbf{7}$ for the Dutch and Russian samples, respectively. In addition, Splitstree analysis was performed and revealed ancillary evidence for a network structure consistent with homologous recombination (Figure 2). While these data confirm the recombinant nature of the samples, it is likely that there are other genetic regions that have undergone recombination and, therefore, it is not possible to determine the extent of genetic exchange unless WGS is performed (Joseph et al., 2011; 2012; Harris et al., 2012; Hadfield et al., 2017).

Overall, there were 106 (32.8\%) putative recombinants (Table 2; Supplementary Table 3), which is similar to our previous studies and those of other investigators (Batteiger et al., 2014b; Dean et al., 2009; Gravningen et al., 2012). Each geographic region contained recombinants, although Europe had a significantly higher number than Russia and the Americas $(p<0.04)$ (Table 2). This result was skewed by the higher rate of recombinants among the Amsterdam population, which would be expected given that the samples came from individuals at high risk for STDs where sexual mixing and import of strains from tourists could increase the chances for multiple $C t$ strain infections and opportunities for recombination. Indeed, rates of $C t$ mixed infections as high as $6 \%$ and $16 \%$ have been reported among men who have sex with men and heterosexual populations, respectively, in Europe, including The Netherlands (Quint et al., 2011; Rodriguez-Dominguez et al., 2015).

The most geographically prevalent ST was 39 with 45 samples, 95\% of which had an ompA genotype of E; there were only two recombinants in this ST: one from Boston with a $\mathrm{D}$ ompA genotype and one from St. Petersburg with a G genotype. E genotypes are known to be the most globally prevalent (Gharsallah et al., 2016; Lee et al., 2006; Lysén et al., 2004; Millman 
et al., 2004; Spaargaren et al., 2004) and the least recombinogenic based on whole genome sequencing (Joseph et al., 2011, 2012). In our dataset, there were 72 E genotypes with an ST to sample ratio of 0.25 ; only the $F$ genotype, the $4^{\text {th }}$ most prevalent genotype with 30 samples, had a lower ratio at 0.17 . The lower ratios indicate greater fitness as these strains are prevalent worldwide and have fewer allelic variants that resolve into fewer STs. This is borne out by the fact that only eight (11\%) of the $72 \mathrm{E}$ genotypes and 0 of the $30 \mathrm{~F}$ genotypes were recombinants (Supplemental Table 3). A recent genome study that included $149 \mathrm{E}$ strains supports our conclusions (Hadfield et al., 2017). Genotype D was also highly prevalent but had a much higher ratio at 0.48 , and 29 (88\%) of 33 samples were recombinants.

We previously found that phylogeny based on MLST resolved the STs along disease phenotype demarcations. As samples have been added to the database, the phenotype resolution has increased to include the LGV phenotype, denoted as clonal cluster-D (CC-D;

Figure 1). Similarly, the tree shows the three main clusters with the trachoma STs as a Subcluster of Cluster I, which resembles those of other reports (Herrmann et al., 2015).

To determine whether the phenotypic groups could be more finely discriminated, we analyzed the database for SNPs that independently or together would identify a phenotype. As in our previous studies (Batteiger et al., 2014a; Dean et al., 2009), specific SNPs correlated with LGV, non-invasive urogenital disease and trachoma. Haplotype 2, which included the non-invasive urogenital disease group required exclusion of strains that were recombinants, specifically D genotypes.

\section{Author Contributions}

Conceived and designed experiments: DD, VS; Wrote the paper: VS, AV, DD; Assisted with editing the paper: EFVE, MN, LS, HJCDV, SAM; Preformed experiments: EFVE, MN, TM, BS; Analyzed data: VS, AV, EFVE, MN, TM, BS, DD; Contributed reagents/materials/analysis tools: VS, LS, HJCDV, CE, JD, SAM, DD. 


\section{Acknowledgements}

We would like to thank Payel Sen, Neda Dastgheyb, and Priyanka Manandhar for excellent technical support.

\section{Supplementary material}

Supplementary material is available online at Frontiers in Cell and Infection Microbiology.

\section{References}

Andersson P, Harris SR, Seth Smith HM, Hadfield J, O'Neill C, Cutcliffe LT, et al. (2016). Chlamydia trachomatis from Australian Aboriginal people with trachoma are polyphyletic composed of multiple distinctive lineages. Nat. Comm. 7, 10688.

Benjamini, Y., and Hochberg, Y. (1995). Controlling the false discovery rate: a practical and powerful approach to multiple testing. J. $R$. Statist. Soc. B 57, 289-300.

Batteiger, B. E., Wan, R., Williams, J. A., He, L., Ma, A., Fortenberry, J. D., et al. (2014a). Novel Chlamydia trachomatis Strains in Heterosexual Sex. Emerg Infect Dis 20.

Batteiger, B. E., Wan, R., Williams, J. A., He, L., Ma, A., Fortenberry, J. D., et al. (2014b). Novel Chlamydia trachomatis strains in heterosexual sex partners, Indianapolis, Indiana, USA. Emerg. Infect. Dis. 20, 18411847.

Baud, D., Regan, L., and Greub, G. (2008). Emerging role of Chlamydia and Chlamydia-like organisms in adverse pregnancy outcomes. Curr. Opin. Infect. Dis. 21, 70-76.
Blas, M. M., Canchihuaman, F. A., Alva, I. E., and Hawes, S. E. (2007). Pregnancy outcomes in women infected with Chlamydia trachomatis: a population-based cohort study in Washington State. Sex. Transm. Infect. 83, 314-318.

Borkowf, C. B. (2006). Constructing binomial confidence intervals with near nominal coverage by adding a single imaginary failure or success. Stat. Med. 25, 3679-3695.

Danby, C. S., Cosentino, L. A., Rabe, L. K., Priest, C. L., Damare, K. C., Macio, I. S., et al. (2016). Patterns of Extragenital Chlamydia and Gonorrhea in Women and Men Who Have Sex With Men Reporting a History of Receptive Anal Intercourse. Sex. Transm. Dis. 43, 105109.

Darville, T. (2005). Chlamydia trachomatis infections in neonates and young children. Semin. Pediatr. Infect. Dis. 16, 235-244.

Dean, D. (2010). "Chapter 77. Pathogenesis of Chlamydial Ocular Infections," in Duane's Foundations of Clinical Ophthalmology. 
Tasman W, Jaeger EA, eds. (Philadelphia, PA: Lippincott Williams \& Wilkins), 678-702.

Dean, D., Bruno, W. J., Wan, R., Gomes, J. P., Devignot, S., Mehari, T., et al. (2009). Predicting phenotype and emerging strains among Chlamydia trachomatis infections. Emerg. Infect. Dis. 15, 1385-1394.

Dean, D., Kandel, R. P., Adhikari, H. K., and Hessel, T. (2008). Multiple Chlamydiaceae species in trachoma: implications for disease pathogenesis and control. PLoS Med. 5, e14.

Dean, D., and Millman, K. (1997). Molecular and mutation trends analyses of omp1 alleles for serovar E of Chlamydia trachomatis. Implications for the immunopathogenesis of disease. J. Clin. Invest. 99, 475-483.

Dean, D., Schachter, J., Dawson, C. R., and Stephens, R. S. (1992). Comparison of the major outer membrane protein variant sequence regions of $\mathrm{B} / \mathrm{Ba}$ isolates: a molecular epidemiologic approach to Chlamydia trachomatis infections. J. Infect. Dis. 166, 383-392.

de Waaij DJ, Dubbink JH, Peters RP, Ouburg S, and Morré SA. (2015). Compariosn of GMT presto assay and Roche cobas $₫ 4800$ CT/NG assay for detection of Chlamydia trachomatis and Neisseria gonorrhoeae in dry swabs. $]$ Microbiol Methods. 118, 70-4.

Excoffier, L., and Lischer, H. E. L. (2010). Arlequin suite ver 3.5: A new series of programs to perform population genetics analyses under Linux and Windows. Mol. Ecol. Resour. 10, 564-567.

Feil, E. J., Li, B. C., Aanensen, D. M., Hanage, W. P., and Spratt, B. G. (2004). eBURST: inferring patterns of evolutionary descent among clusters of related bacterial genotypes from multilocus sequence typing data. J. Bacteriol. 186, 1518-1530.

Gharsallah, H., Bom, R. J. M., Bruisten, S. M., Himschoot, M., Frikha-Gargouri, O., and Hammami, A. (2016). Identification of a dominant Chlamydia trachomatis strain in patients attending sexual transmitted infection clinic and female sex workers in Tunisia using a high resolution typing method. Infect. Genet. Evol. J. Mol. Epidemiol. Evol. Genet. Infect. Dis. 44, 444-449.

Gomes JP, Bruno WJ, Borrego MJ, Dean D. (2004). Recombination in the genome of Chlamydia trachomatis involving the polymorphic membrane protein $\mathrm{C}$ relative to ompA and evidence for horizontal gene transfer. $J$. Bacteriol. 186, 4295-306.

Gomes JP, Bruno WJ, Borrego MJ, Nunes A, Florindo C, Dean D. (2006). Polymorphisms in the nine polymorphic membrane proteins of Chlamydia trachomatis across all serovars: Evidence for Da recombination and correlation with tissue tropism. J. Bacteriol:;188, 275-86.

Gomes JP, Bruno WJ, Nunes A, Santos N, Florindo C, Borrego MJ, Dean D. (2007). Evolution of Chlamydia trachomatis diversity occurs by widespread interstrain recombination involving hotspots. Genome Research 1, 5060.

Götz, H. M., Bom, R. J. M., Wolfers, M. E. G., Fennema, J., van den Broek, I. V. F., Speksnijder, A. G. C. L., et al. (2013). Use of Chlamydia 
trachomatis high-resolution typing: an extended case study to distinguish recurrent or persistent infection from new infection. Sex. Transm. Infect., 1-6.

Gravningen, K., Christerson, L., Furberg, A. S., Simonsen, G. S., Ödman, K., Ståhlsten, A., et al. (2012). Multilocus sequence typing of genital Chlamydia trachomatis in norway reveals multiple new sequence types and a large genetic diversity. PLOS ONE 7.

Hadfield J, Harris SR, Seth-Smith HMB, Parmar S, Andersson P, Giffard PM, et al. (2017). Comprehensive global genome dynamics of Chlamydia trachomatis show ancient diversification followed by contemporary mixing. Genome Res. 7, 1220-1229.

Harris SR, Clarke IN, Seth-Smith HM, Solomon AW, Cutcliffe LT, Marsh P, et al. (2012). Wholegenome analysis of diverse Chlamydia trachomatis strains identifies phylogenetic relationships masked by current clinical typing. Nat. Genet. 44, 413-9, S1.

Herrmann, B., Isaksson, J., Ryberg, M., Tångrot, J., Saleh, I., Versteeg, B., et al. (2015). Global Multilocus Sequence Type Analysis of Chlamydia trachomatis Strains from 16 Countries. J. Clin. Microbiol. 53, 2172-2179.

Horn, M., Collingro, A., Schmitz-Esser, S., Beier, C. L., Purkhold, U., Fartmann, B., et al. (2004). Illuminating the evolutionary history of chlamydiae. Science 304, 728-730.

Hunter, P. R., and Gaston, M. A. (1988). Numerical index of the discriminatory ability of typing systems: an application of Simpson's index of diversity. J. Clin. Microbiol. 26, 2465-2466.
Isaksson, J., Gallo Vaulet, L., Christerson, L., Ruettger, A., Sachse, K., Entrocassi, C., et al. (2016). Comparison of multilocus sequence typing and multilocus typing microarray of Chlamydia trachomatis strains from Argentina and Chile. J. Microbiol. Methods 127, 214-218.

Joseph, S. J., Didelot, X., Gandhi, K., Dean, D., and Read, T. D. (2011). Interplay of recombination and selection in the genomes of Chlamydia trachomatis. Biol. Direct 6, 28.

Joseph, S. J., Didelot, X., Rothschild, J., de Vries, H. J. C., Morré, S. A., Read, T. D., et al. (2012). Population genomics of Chlamydia trachomatis: insights on drift, selection, recombination, and population structure. Mol. Biol. Evol. 29, 3933-3946.

Joseph SJ, Li B, Ghonasgi T, Qin ZC, Dean D, and Read TD. (2014). Direct amplification, sequencing and profiling of Chlamydia trachomatis strains in single and mixed infection clinical samples. PLoS One 9, e99290.one.0109670.

Klint, M., Fuxelius, H. H., Goldkuhl, R. R., Skarin, H., Rutemark, C., Andersson, S. G. E., et al. (2007). High-resolution genotyping of Chlamydia trachomatis strains by multilocus sequence analysis. J. Clin. Microbiol. 45, 1410-1414.

Labiran, C., Marsh, P., Zhou, J., Bannister, A., Clarke, I. N., Goubet, S., et al. (2016). Highly diverse MLVA-ompA genotypes of rectal Chlamydia trachomatis among men who have sex with men in Brighton, UK and evidence for an HIVrelated sexual network. Sex. Transm. Infect. 92, 299-304. 
Librado, P., Rozas, J. (2009). DnaSP v5: a software for comprehensive analysis of DNA polymorphism data. Bioinformatics 25,1451 1452.

Lee, G., Park, J., Kim, B., Kim, S.-A., Yoo, C.-K., and Seong, W. K. (2006). OmpA genotyping of Chlamydia trachomatis from Korean female sex workers. J. Infect. 52, 451-454.

Lysén, M., Osterlund, A., Rubin, C.-J., Persson, T., Persson, I., and Herrmann, B. (2004). Characterization of ompA genotypes by sequence analysis of DNA from all detected cases of Chlamydia trachomatis infections during 1 year of contact tracing in a Swedish County. J. Clin. Microbiol. 42, 1641-1647.

Maiden, M. C., Bygraves, J. A., Feil, E., Morelli, G., Russell, J. E., Urwin, R., et al. (1998). Multilocus sequence typing: a portable approach to the identification of clones within populations of pathogenic microorganisms. Proc. Natl. Acad. Sci. U. S. A. 95, 3140-3145.

Mårdh, P.-A. (2004). Tubal factor infertility, with special regard to chlamydial salpingitis. Curr. Opin. Infect. Dis. 17, 49-52.

Millman K, Tavere S, Dean D. (2001). Recombination in the ompA gene but not the omcB gene of Chlamydia contribute to serovar specific differences in tissue tropism, immune surveillance and persistence of the organism. J. Bacteriol. 183, 5997-6008.

Millman, K., Black, C. M., Johnson, R. E., Stamm, W. E., Jones, R. B., Hook, E. W., et al. (2004). Population-based genetic and evolutionary analysis of Chlamydia trachomatis urogenital strain variation in the United States. J. Bacteriol. 186, 2457-2465.

Morré, S. A., Van Valkengoed, I. G., Moes, R. M., Boeke, A. J., Meijer, C. J., and Van den Brule, A. J. (1999). Determination of Chlamydia trachomatis prevalence in an asymptomatic screening population: performances of the LCx and COBAS Amplicor tests with urine specimens. J. Clin. Microbiol. 37, 3092-3096.

Pannekoek, Y., Morelli, G., Kusecek, B., Morré, S. A., Ossewaarde, J. M., Langerak, A. A., et al. (2008a). Multi locus sequence typing of Chlamydiales: clonal groupings within the obligate intracellular bacteria Chlamydia trachomatis. BMC Microbiol. 8, 42.

Pannekoek, Y., Morelli, G., Kusecek, B., Morré, S. A., Ossewaarde, J. M., Langerak, A. A., et al. (2008b). Multi locus sequence typing of Chlamydiales: clonal groupings within the obligate intracellular bacteria Chlamydia trachomatis. BMC Microbiol. 8, 42.

Perkins, E., and Hill, D. eds. (2013). Scientific Foundations of Ophthalmology. ButterworthHeinemann.

Peuchant, O., Touati, A., Sperandio, C., Hénin, N., Laurier-Nadalié, C., Bébéar, C., et al. (2016). Changing Pattern of Chlamydia trachomatis Strains in Lymphogranuloma Venereum Outbreak, France, 2010-2015. Emerg. Infect. Dis. 22, 1945-1947.

Quint, K. D., Bom, R. J., Quint, W. G. V., Bruisten, S. M., van der Loeff, M. F. S., Morré, S. A., et al. (2011). Anal infections with concomitant Chlamydia trachomatis genotypes among 
men who have sex with men in Amsterdam, the Netherlands. BMC Infect. Dis. 11, 63.

Rodriguez-Dominguez, M., Gonzalez-Alba, J. M., Puerta, T., Menendez, B., Sanchez-Diaz, A. M., Canton, R., et al. (2015). High Prevalence of Co-Infections by Invasive and Non-Invasive Chlamydia trachomatis Genotypes during the Lymphogranuloma Venereum Outbreak in Spain. PloS One 10, e0126145.

Rowley, J., Toskin, I., Ndowa, F., World Health Organization, World Health Organization, and Reproductive Health and Research (2012). Global incidence and prevalence of selected curable sexually transmitted infections, 2008. Geneva, Switzerland: World Health Organization Available at: http://apps.who.int/iris/bitstream/10665/ 75181/1/9789241503839_eng.pdf

[Accessed October 21, 2015].

Schillinger, J. A., Katz, B. P., Markowitz, L. E., Braslins, P. G., Shrier, L. A., Madico, G., et al. (2016). Genotype-Specific Concordance of Chlamydia trachomatis Genital Infection Within Heterosexual Partnerships. Sex. Transm. Dis. 43, 741-749.

Seth-Smith HM, Harris SR, Skilton RJ, Radebe FM, Golparian D, Shipitsyna E, et al. (2013). Whole-genome sequences of Chlamydia trachomatis directly from clinical samples without culture. Genome Res. 5, 855-66.

Sethi, G., Allason-Jones, E., Richens, J., Annan, N. T., Hawkins, D., Ekbote, A., et al. (2009). Lymphogranuloma venereum presenting as genital ulceration and inguinal syndrome in men who have sex with men in London, UK. Sex. Transm. Infect. 85, 165-170.

Schliep, K. P. (2010). phangorn: phylogenetic analysis in R. Bioinformatics 27, 592-593.

Shalepo, K., Savicheva, A., Shipitsyna, E., Unemo, M., and Domeika, M. (2006). Diagnosis of Chlamydia trachomatis in Russia--in-house PCR assays may be effective but overall optimization and quality assurance are urgently needed. APMIS Acta Pathol. Microbiol. Immunol. Scand. 114, 500-507.

Shipitsyna, E., Shalepo, K., Savicheva, A., Unemo, M., and Domeika, M. (2007). Pooling samples: the key to sensitive, specific and costeffective genetic diagnosis of Chlamydia trachomatis in low-resource countries. Acta Derm. Venereol. 87, 140-143.

Simpson, E. H. (1949). Measurement of Diversity. Nature 163.

Smelov, V., Quint, K. D., Pleijster, J., Savelkoul, P. H. M., Shalepo, K., Shipitsyna, E., et al. (2009). Chlamydia trachomatis serovar distributions in Russian men and women: a comparison with Dutch serovar distributions. Drugs Today Barc. Spain 199845 Suppl B, 33-38.

Spaargaren, J., Verhaest, I., Mooij, S., Smit, C., Fennema, H. S. A., Coutinho, R. A., et al. (2004). Analysis of Chlamydia trachomatis serovar distribution changes in the Netherlands (1986-2002). Sex. Transm. Infect. 80, 151-152.

Spratt, B. G., Hanage, W. P., and Feil, E. J. (2001). The relative contributions of recombination and point mutation to the diversification of 
bacterial clones. Curr. Opin. Microbiol. 4, 602606.

Tamura, K., Stecher, G., Peterson, D., Filipski, A., and Kumar, S. (2013). MEGA6: Molecular Evolutionary Genetics Analysis version 6.0. Mol. Biol. Evol. 30, 2725-2729.

Urwin, R., and Maiden, M. C. J. (2003). Multi-locus sequence typing: a tool for global epidemiology. Trends Microbiol. 11, 479-487.

van Belkum, A., Tassios, P. T., Dijkshoorn, L., Haeggman, S., Cookson, B., Fry, N. K., et al. (2007). Guidelines for the validation and application of typing methods for use in bacterial epidemiology. Clin. Microbiol. Infect. Off. Publ. Eur. Soc. Clin. Microbiol. Infect. Dis. 13 Suppl 3, 1-46.

Versteeg, B., Himschoot, M., van den Broek, I. V. F., Bom, R. J. M., Speksnijder, A. G. C. L., Schim van der Loeff, M. F., et al. (2015). Urogenital Chlamydia trachomatis strain types, defined by high-resolution multilocus sequence typing, in relation to ethnicity and urogenital symptoms among a young screening population in Amsterdam, The Netherlands. Sex. Transm. Infect. 91, 415-422.

WHO. Sexually transmitted infections (STIs)

Available at:

http://www.who.int/mediacentre/factsheet s/fs110/en/ [Accessed June 5, 2015]. 
Figure 1: eBURST phylogeny for $C$. trachomatis geographic samples by ST.
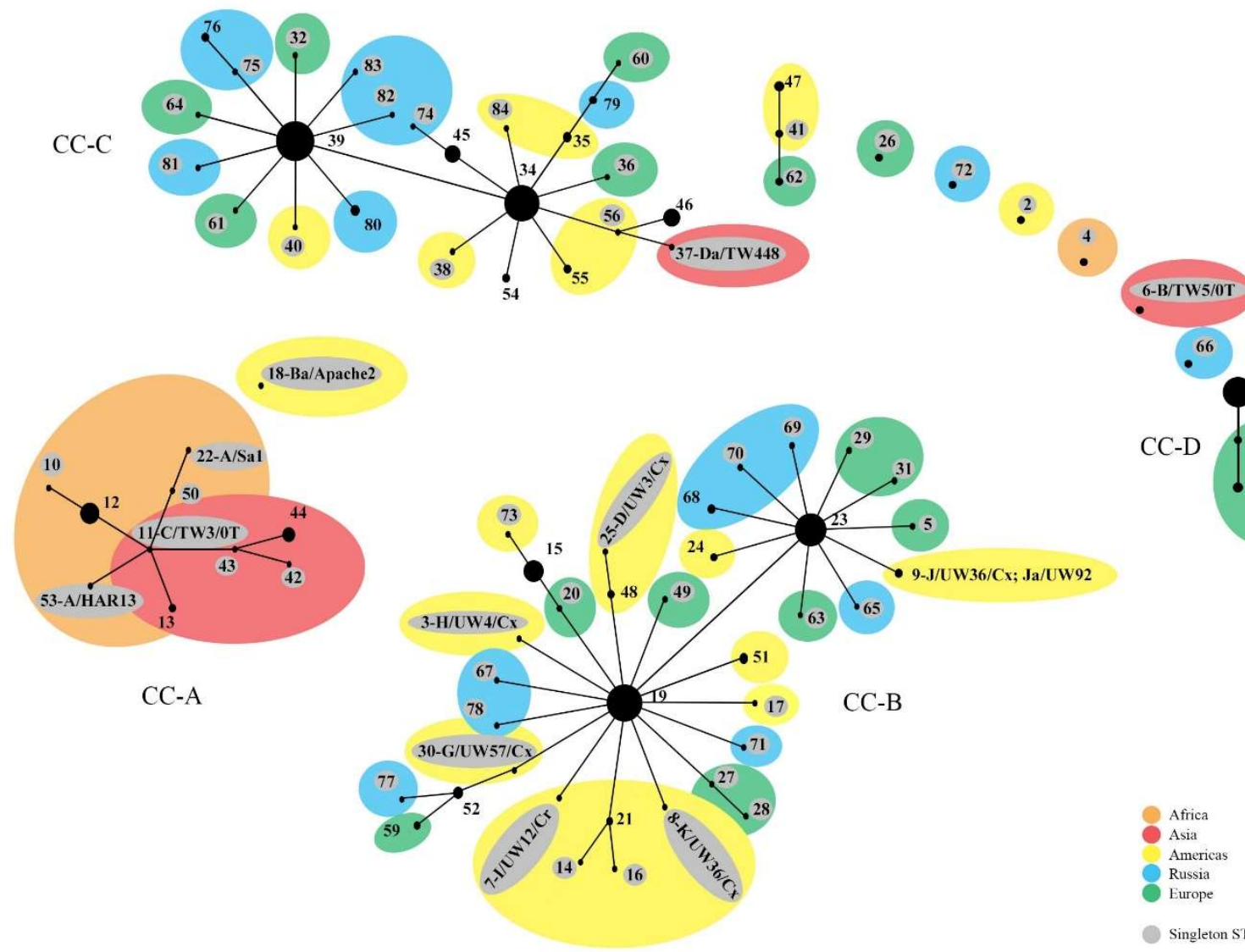

CC-D
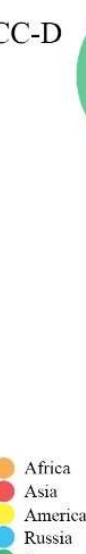

Russia

Singleton ST

The numbers represent the Sequence Type (ST). STs that are linked differ at single multilocus sequences (i.e., allelic number) and represent clonal groups. STs in the same clonal group are likely descended from the same recent ancestor, dependent on the region. Three distinct clonal clusters (CC) that correlate with disease phenotypes are shown: A, trachoma samples; B, non-prevalent urogenital samples; and C, prevalent urogenital samples. Large colored circles indicate what region multiple STs in a sub-group originated from. STs shaded grey are singleton STs. The area of the circle represents the number of samples of each ST. Orange, Africa; red, Asia; yellow, Americas; blue, Russia; green, Western Europe. 
Figure 2: Phylogenetic tree for C. trachomatis nucleotide sequences by ST.

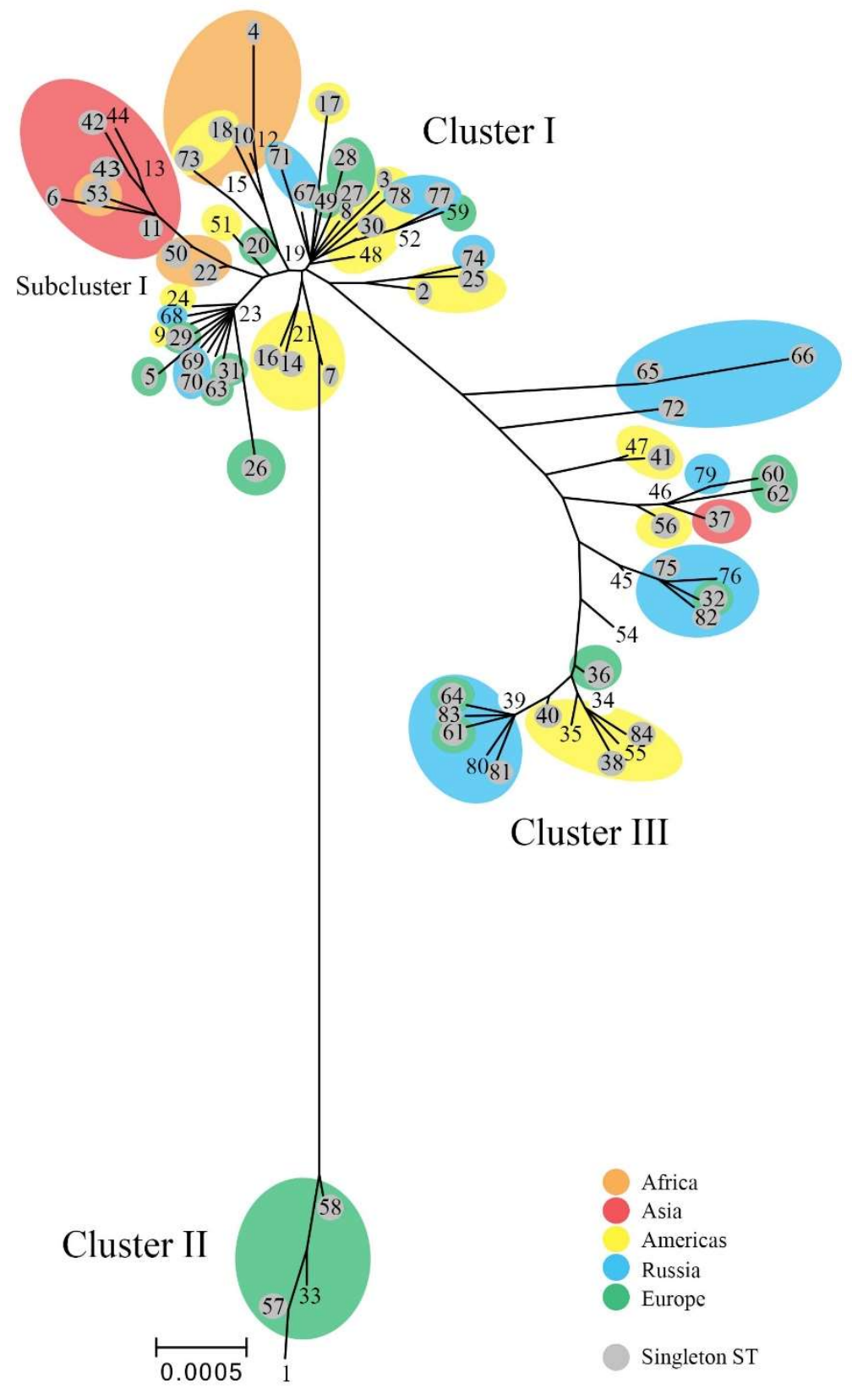

The numbers represent the Sequence Type (ST). The tree was constructed using the matrix of pairwise differences between the 84 ST concatenated nucleotide sequences for the seven MLST loci using the maximum composite likelihood method for estimating genetic distances. Only bootstrap values $(1,000$ replicates $)$ of $>70 \%$ are shown at branch points in the tree. STs (shaded grey) are singletons. Orange, Africa; red, Asia; yellow, Americas; blue, Russia; green, Western Europe. Scale bar indicates number of substitutions per site. 
Figure 3: Splitstree for C. trachomatis nucleotide sequences by ST.

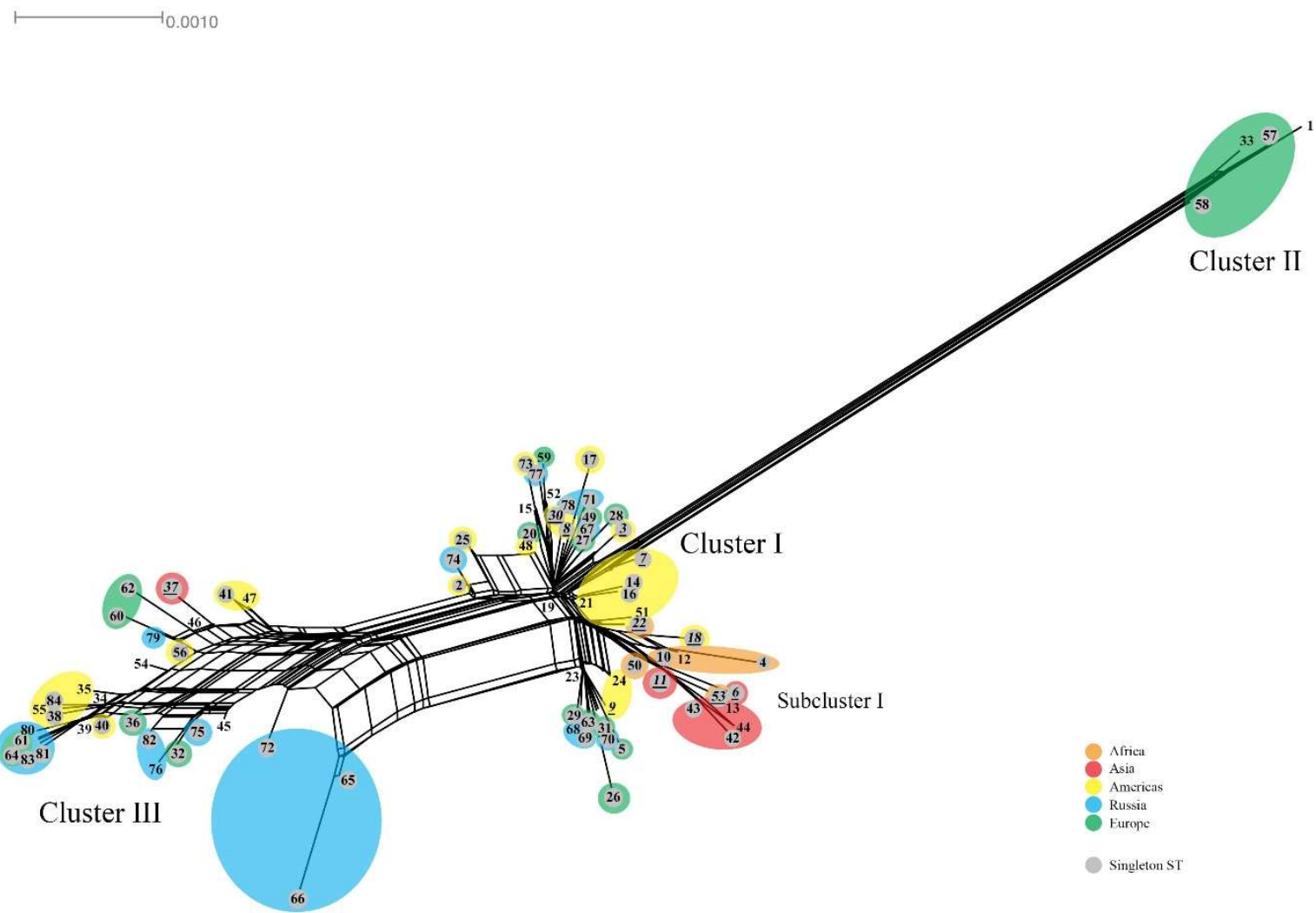

The numbers represent the Sequence Type (ST). The tree was obtained by using the seven loci for the 84 ST concatenated nucleotide sequences. STs (shaded grey) are singletons. Orange, Africa; red, Asia; yellow, Americas; blue, Russia; green, Western Europe. Scale bar indicates number of substitutions per site. 



\section{Chapter 5}

\section{Delayed microbial cure of}

lymphogranuloma venereum

proctitis with doxycycline

treatment 



\title{
Delayed microbial cure of lymphogranuloma venereum proctitis with doxycycline treatment
}

\author{
Henry J. C. de Vries, ${ }^{1,3,6}$ Vitaly Smelov, ${ }^{8}$ \\ Judith G. Middelburg, ${ }^{1}$ Jolein Pleijster, 4 \\ Arjen G. Speksnijder, ${ }^{2}$ and Servass A. Morré ${ }^{5,6,7}$
}

Clin Infect Dis. 2009 Mar 1;48(5):e53-6.

${ }^{1}$ Sexually Transmitted Infection Outpatient Clinic, and 2 Public Health Laboratory, Cluster Infectious Diseases, Health Service Amsterdam, ${ }^{3}$ Department of Dermatology, Academic Medical Center, University of Amsterdam, and Departments of ${ }^{4}$ Pathology, Laboratory of Immunogenetics, and ${ }^{5}$ Internal Medicine, Section of Infectious Diseases, Vrije Universiteit Medical Center, Amsterdam, ${ }^{6}$ Centre for Infectious Diseases Control, National Institute of Public Health and the Environment, Bilthoven, and 7Department of Medical Microbiology, Academic Hospital Maastricht, Maastricht, The Netherlands; and 8Faculty of Medicine, St. Petersburg State University, St. Petersburg, Russia. 


\begin{abstract}
Microbial cure of chlamydia proctitis (lymphogranuloma venereum [LGV] and non-LGV) with doxycycline treatment was evaluated by chlamydia DNA and RNA persistence in anal swab specimens. In LGV proctitis, RNA persisted for up to 16 days. In non-LGV chlamydia proctitis, DNA was undetectable after 7 days. These findings support the Centers for Disease Control and Prevention's treatment recommendation of a 21-day doxycycline regimen for LGV proctitis and a 7-day regimen for non-LGV chlamydia proctitis. Delayed microbial cure of LGV proctitis should be considered in improved treatment regimens.
\end{abstract}




\section{Introduction}

Lymphogranuloma venereum (LGV) is an invasive ulcerative sexually transmitted infection caused by Chlamydia trachomatis (chlamydia) biovar L [1]. The infection spreads beyond mucosal linings into connective tissue layers and through lymphatic vessels to loco-regional lymph nodes and causes destructive and systemic inflammatory reactions. In contrast, chlamydia biovars D-K (non-LGV biovars) remain confined to genital and anal mucosa and generally cause few to no symptomatic infections.

LGV can cause an anorectal syndrome characterized by severe proctitis with anal cramps (tenesmus), pain, bloody dis- charge, and constipation caused by local edema. If left un- treated, this can lead to irreversible anal strictures causing soiling, pain, constipation, and megacolon.

LGV is endemic in tropical climate regions [2]. Until 2003, sporadic cases were reported in Western nations, but since 2003, an ongoing epidemic of LGV proctitis among men who have sex with men has emerged, first reported in Rotterdam, The Netherlands, then in other Western countries [3].

It is generally accepted to treat LGV infection with antibiotic regimens of longer duration, compared with the duration used to treat anogenital infections caused by non-LGV chlamydia biovars. The Centers for Disease Control Prevention (CDC) 2006 sexually transmitted disease treatment guidelines recommend a minimum 21-day oral course of doxycycline (100 mg twice daily) for LGV proctitis but only a 7-day course for proctitis caused by non-LGV chlamydia infections [4]. These recommendations are partly based on a meta-analysis by Mc- Lean et al. [5]. Nonetheless, the optimal treatment duration for proctitis caused by both LGV and non-LGV biovars has never been studied and is based on clinical experience only, partly because of a lack of criteria by which efficacy can be measured.

In this study, we evaluated the microbial cure of LGV proctitis and non-LGV chlamydia proctitis treated with the CDC standard treatment regimens. Anal swab specimens collected during and after treatment were screened for chlamydia DNA. Traces of bacterial DNA can persist for prolonged periods, even after successful elimination of infectious organisms [6]. In contrast, chlamydia RNA is short lived and 
can only be produced by live metabolically active chlamydia bacteria [7]. For this reason, additional chlamydia RNA tests were performed for patients with anal swab specimens positive for chlamydia DNA. Treatment was considered successful if no chlamydia DNA or RNA was detected at the end of the doxycycline regimen.

\section{Methods}

This study was approved by the Academic Medical Centre Ethical Committee, Amsterdam, the Netherlands. All participants were routinely screened for sexually transmitted infections, including chlamydia and LGV, as described elsewhere $[8,9]$. In short, all men reporting receptive anal sex in the previous 6 months were routinely checked for chlamydia proctitis by collection of mucosal swab specimens during anoscopy. Complaints and perianal and intra-anal mucous membrane abnormalities were recorded. Gram-stained anal smears were performed, and the number of polymorphous nu- clear cells counted per high-power light microscopical field was determined. If 110 polymorphous nuclear cells per high-power light microscopical field were counted, patients started with presumptive treatment with doxycycline (100 mg orally twice daily).

Chlamydia proctitis was diagnosed (biovar indiscriminate) within 1 week after screening, when chlamydia DNA was detected by Cobas Amplicor (Roche). Patients with chlamydia proctitis were asked at random for written consent to participate, and additional anal swab specimens for chlamydia diagnostics were collected. If presumptive treatment had not been started 1 week earlier, doxycycline (100 mg orally twice daily) was started. For participants already receiving presumptive treatment, the doxycycline regimen was prolonged. For all patients, biovar-L analysis of chlamydia-positive anal swab specimens was performed, as described elsewhere $[10,11]$. If LGV proctitis was excluded, the doxycycline regimen was limited to a minimum of 7 days. If LGV proctitis was diagnosed (by biovar-L analysis) the doxycycline course was prolonged for 21 days. Anal swab specimens were collected at subsequent visits during weeks $1,2,3$, and $6(\sim 7, \sim 14, \sim 21$, and $\sim 42$ days, respectively, after the commencement of doxycycline treatment). During this follow-up period, patients were asked to refrain from sexual contact. Swab 
specimens were eluted in $2 \mathrm{~mL}$ of 2SP medium (Roche). For chlamydia DNA-positive samples, biovar-L determination was performed. A second anal swab specimen was stored at $-80^{\circ} \mathrm{C}$ in $2 \mathrm{~mL}$ of $\mathrm{L} 6$ buffer and was later thawed for RNA extraction. Nucleic acid (DNA-RNA) was isolated, using the commercially available EasyMAG system (Biomerieux), from anal swab specimens positive for chlamydia DNA or when inhibition of the DNA test occurred. An equivalent of $10 \mathrm{~mL}$ of the $\mathrm{L} 6$ extract was used in an Aptima CT single assay (Genprobe) targeting chlamydia ribosomal RNA by TMA analysis with use of a Tigris DTS analyzer (Genprobe). Participants who missed 11 visit were excluded from the overall study analysis.

\section{Results}

Thirty-one male patients with LGV proctitis and 31 with non-LGV chlamydia proctitis were included in the study. Eleven patients with LGV proctitis and 5 with non-LGV chlamydia proctitis missed 11 study visit and were excluded. The remaining 20 patients with LGV proctitis and 26 patients with non-LGV chlamydia proctitis were screened as described in table 1.

One patient with LGV proctitis was chlamydia biovar-L DNA positive and chlamydia RNA positive on day 10 and chlamydia RNA positive (the DNA test was inhibited) on day 16; the patient was chlamydia DNA and RNA negative at the following visit, on day 30. Another patient with LGV proctitis was biovar-L DNA positive and chlamydia RNA positive on day 6 and DNA and RNA negative after 13 days of treatment. Two patients who received a diagnosis of LGV on the inclusion date were chlamydia non-LGV DNA positive until 14 days after the initiation of treatment. In 1 of these 2 patients, chlamydia RNA was detected on day 7, but both patients were RNA negative after 14 days of treatment. For 2 patients with LGV (at weeks 1 and 2), the internal control of the DNA test showed inhibition of the amplification. Both samples were positive in the RNA test.

At the end of therapy (week 3 visit), LGV proctitis persistent mucous membrane abnormalities were observed in 6 of 16 patients during anoscopic examination. For this reason, doxycycline treatment was prolonged for an additional 21 days for 5 of these 6 patients. None of the 4 patients with LGV proctitis who had persistent 
chlamydia RNA positivity during treatment had mucous membrane abnormalities at the end of the 21-day regimen.

All but 1 of the patients with non-LGV proctitis were chlamydia DNA negative after 7 days of treatment and remained negative up until the final week 6 visit. The 1 patient was chlamydia non-LGV biovar DNA positive on day 36, after repeated negative chlamydia DNA test results on days 8, 10, and 20.

\section{Discussion}

In the present study, we showed persistence of chlamydia RNA in patients with LGV proctitis for up to 16 days during doxycycline treatment. The continued presence of chlamydia RNA suggests the perseverance of metabolically active, infectious pathogens and supports the CDC recommendation for prolonged treatment of LGV treatment for at least 21 days.

In the patients with non-LGV chlamydia proctitis, doxycycline was able to eliminate chlamydia DNA within 7 days, which supports the CDC-recommended shorter doxycycline regimen for treatment of non-LGV chlamydia proctitis, compared with the treatment regimen for LGV proctitis. In 1 patient with non-LGV chlamydia proctitis who tested DNA negative at the week 1, 2, and 3 visits, chlamydia DNA positivity recurred at the week 6 visit. This patient reported unprotected receptive anal sex after the initial treatment, and chlamydia reinfection likely explains the chlamydia DNA recurrence.

The CDC recommends follow-up for patients with LGV until symptoms have disappeared. Some clinicians advise the extension of doxycycline treatment to 42 days if symptoms persist after the initial 21-day regimen. We found no association between delayed microbial cure and persisting mucosal abnormalities; all patients with LGV who had mucosal abnormalities after therapy completion showed microbial cure within the first week. These findings do not support an extended 42-day treatment regimen for LGV proctitis. They do support the immunopathological hypothesis that suggests that LGV disease is caused by a chronic inflammatory process propelled by persisting bacterial peptides long after microbial cure has been achieved [12]. It is doubtful that these inflammatory processes will respond to 
antimicrobial therapy, but they may require anti-inflammatory approaches, such as corticosteroid therapy. Moreover, doxycycline can cause anal mucosal abnormalities as an adverse effect, which may explain ongoing symptoms after microbial cure of LGV proctitis.

In 3 patients who received a diagnosis of LGV proctitis on the inclusion date, chlamydia DNA of non-LGV biovars persisted during treatment, which suggests that the initial infection included a mixture of different chlamydia biovars that became undetectable at different times. Chlamydia infection caused by 11 biovar could affect diagnostics and requires in-depth investigation. New diagnostic methods that are able to detect multiple biovars in 1 sample could provide important data on the spread of mixed infections at the population level $[13,14]$. Under in vitro conditions, C. trachomatis can enter a persistent state after exposure to doxycycline [15]. To our knowledge, this is the first human study to show that chlamydia biovar-L organisms are able to survive continued exposure to doxycycline for a longer period than are chlamydia non-LGV biovars. We revealed that prolonged chlamydia-eradicating levels of doxycycline are warranted for successful microbial cure of LGV proctitis. This has implications for improved treatment regimens for LGV infections. A single-dose azithromycin regimen is effective for genital non-LGV chlamydia infections. Some experts recommend $1 \mathrm{~g}$ of azithromycin given weekly for 3 weeks for the treatment of LGV, but to date, clinical data for this regimen are lacking [5]. Our data support the necessity of prolonged antichlamydial treatment regimens for LGV proctitis.

\section{Acknowledgments}

We thank Sander Ouburg and Arnold Catsburg for data management and excellent laboratory assessment of the samples.

\section{Financial support}

Research and Development Fund of the Health Service Amsterdam.

Potential conflicts of interest. All authors: no conflicts. 
Table 1. Chlamydia trachomatis test results for patients with lymphogranuloma venereum (LGV) proctitis and non-LGV chlamydia proctitis at 5 different time points after the start of treatment.

\begin{tabular}{|c|c|c|c|c|c|c|c|c|c|c|}
\hline \multicolumn{7}{|c|}{ LGV proctitis ${ }^{a}$} & \multicolumn{4}{|c|}{ non-LGV chlamydia proctitis ${ }^{b}$} \\
\hline $\begin{array}{l}\text { Visit, } \\
\text { week }\end{array}$ & $\mid \begin{array}{l}\text { No. of } \\
\text { patients } \\
\text { evaluated }\end{array}$ & $\begin{array}{l}\text { Time from } \\
\text { treatment to } \\
\text { positive test } \\
\text { result, mean } \\
\text { days } \pm \text { SD }\end{array}$ & $\begin{array}{l}\text { No. of } \\
\text { patients } \\
\text { positive for } \\
\text { chlamydia } \\
\text { DNA }\end{array}$ & $\begin{array}{l}\text { Proportion of } \\
\text { patients } \\
\text { positive for } \\
\text { biovar L }\end{array}$ & $\begin{array}{l}\text { No. of } \\
\text { patients } \\
\text { positive } \\
\text { for } \\
\text { chlamydia } \\
\text { RNA }\end{array}$ & $\begin{array}{l}\text { No. of } \\
\text { patient } \\
\text { evaluated }\end{array}$ & $\begin{array}{l}\text { Time from } \\
\text { treatment to } \\
\text { positive test } \\
\text { result, mean } \\
\text { days } \pm \mathrm{SD}^{\mathrm{d}}\end{array}$ & $\begin{array}{l}\text { No. of } \\
\text { patients } \\
\text { positive for } \\
\text { chlamydia } \\
\text { DNA }\end{array}$ & $\begin{array}{l}\text { Proportion } \\
\text { of patients } \\
\text { positive for } \\
\text { biovar L }\end{array}$ & $\begin{array}{l}\text { No. of } \\
\text { patients } \\
\text { positive for } \\
\text { chlamydia } \\
\text { RNA }\end{array}$ \\
\hline 0 & 20 & NA & 20 & $20 / 20$ & NA & 26 & NA & 26 & $0 / 26$ & NA \\
\hline 1 & 17 & $7.9 \pm 1.5$ & 5 & $2 / 5$ & 4 & 26 & $7.3 \pm 1.1$ & 0 & NA & NA \\
\hline 2 & 19 & $14.3 \pm 1.8$ & 2 & $0 / 2$ & 1 & 21 & $14.1 \pm 1.4$ & 0 & NA & NA \\
\hline 3 & 17 & $21.1 \pm 1.3$ & 0 & NA & NA & 24 & $21.0 \pm 1.1$ & 0 & NA & NA \\
\hline 6 & 19 & $42.8 \pm 5.3$ & 0 & NA & NA & 26 & $45.5 \pm 8.2$ & 1 & $0 / 1$ & 1 \\
\hline
\end{tabular}

NOTE. NA, not applicable. ${ }^{a}$ Patients with LGV proctitis ( $n \mathbf{p}$ 20) were treated with a 21-day regimen of doxycycline (100 mg orally twice daily); ${ }^{\mathrm{b}}$ Patients with non-LGV chlamydia proctitis ( $\left.n \mathbf{p} 26\right)$ were treated with a minimum 7-day regimen of doxycycline (100 mg orally twice daily);

${ }^{c}$ Patients from whom swab specimens for $C$. trachomatis tests could be obtained; ${ }^{\mathrm{d}}$ Time of swab specimen collection was measured from start of doxycycline therapy. 


\section{References}

1. Stamm WE. Lymphogranuloma venereum. In: Holmes KK, Sparling PF, Stamm WE, Piot P, Wasserheit JN, eds. Sexually transmitted diseases. 4th ed. New York: McGraw Hill Medical, 2008:595-606.

2. Sturm PD, Moodley P, Govender K, Bohlken L, Vanmali T, Sturm AW. Molecular diagnosis of lymphogranuloma venereum in patients with genital ulcer disease. $J$ Clin Microbiol 2005; 43:2973-5.

3. Koedijk FD, de Boer I, de Vries HJ, Thiesbrummel HF, van der Sande MA. An ongoing outbreak of lymphogranuloma venereum in The Netherlands, 2006-2007. Euro Surveill 2007; 12:E070419.

4. Workowski KA, Berman SM. Sexually transmitted diseases treatment guidelines, 2006. MMWR Recomm Rep 2006; 55:1-94.

5. McLean CA, Stoner BP, Workowski KA. Treatment of lymphogranuloma venereum. Clin Infect Dis 2007; 44(Suppl 3):S147-52.

6. Workowski KA, Lampe MF, Wong KG, Watts MB, Stamm WE. Long-term eradication of Chlamydia trachomatis genital infection after antimicrobial therapy: evidence against persistent infection. JAMA 1993; 270:2071-5.

7. Gerard HC, Branigan PJ, Balsara GR, Heath C, Minassian SS, Hudson AP. Viability of Chlamydia trachomatis in fallopian tubes of patients with ectopic pregnancy. Fertil Steril 1998; 70:945-8.

8. de Vries HJ, Van der Bij AK, Fennema JS, et al. Lymphogranuloma venereum proctitis in men who have sex with men is associated with anal enema use and high-risk behavior. Sex Transm Dis 2008; 35:203-8.

9. Van der Bij AK, Spaargaren J, Morre $\mathrm{SA}$, et al. Diagnostic and clinical implications of anorectal lymphogranuloma venereum in men who have sex with men: a retrospective case-control study. Clin Infect Dis 2006; 42:186-94.

10. Morre SA, Spaargaren J, Fennema JS, de Vries HJ. Molecular diagnosis of lymphogranuloma venereum: PCRbased restriction fragment length polymorphism and real-time PCR. J Clin Microbiol 2005; 43:5412-3.

11. Morre SA, Spaargaren J, Fennema JS, de Vries HJ, Coutinho RA, Pena AS. Real-time polymerase chain reaction to diagnose lymphogranuloma venereum. Emerg Infect Dis 2005; 11:1311-2.

12. Zvillich M, Sarov I. The persistence of Chlamydia trachomatis elementary body cell walls in human polymorphonuclear leucocytes and induction of a chemiluminescent response. J Gen Microbiol 1989; 135: 95-104.

13. Chen $\mathrm{CY}$, Chi KH, Alexander S, Ison CA, Ballard RC. A real-time 
quadriplex PCR assay for the

diagnosis of rectal

lymphogranuloma venereum and

non-lymphogranuloma venereum

Chlamydia trachomatis infections. Sex

Transm Infect 2008; 84:273-6.

14. Jalal H, Stephen H, Alexander S, Carne

C, Sonnex C. Development of real-time

PCR assays for genotyping of Chlamydia trachomatis. J Clin Microbiol 2007;

45:2649-53.

15. Mpiga P, Ravaoarinoro M. Effects of sustained antibiotic bactericidal treatment on Chlamydia trachomatisinfected epithelial-like cells (HeLa) and monocyte-like cells (THP-1 and U-937). Int J Antimicrob Agents 2006; 27:31624. 


\section{PART II.}

Human papillomavirus infection 



\section{Chapter 6}

Expressed prostate secretions in the study of human papillomavirus epidemiology in the male 


\title{
Expressed prostate secretions in the study of human papillomavirus epidemiology in the male
}

\author{
Vitaly Smelov ${ }^{1,2,3,4^{*}}$, \\ Carina Eklund ${ }^{1}$, \\ Davit Bzhalava ${ }^{1}$, \\ Andrey Novikov², \\ Joakim Dillner ${ }^{1}$
}

PLoS One. 2013 Jun 14;8(6):e66630.

${ }^{1}$ Department of laboratory Medicine, Karolinska Institutet, Stockholm, Sweden; ${ }^{2}$ Department of Urology and Andrology, North-Western State Medical University named after I.I. Mechnikov, St. Petersburg, Russia; ${ }^{3}$ St. Petersburg State University Outpatient Clinic, St. Petersburg, Russia, 4"OOO Mikrobiomed" medical center and Laboratory of Microbiology, D.O. Ott Research Institute of Obstetrics and Gynaecology, St. Petersburg, Russia. 


\begin{abstract}
Introduction. Exploring different sampling sites and methods is of interest for studies of the epidemiology of HPV infections in the male. Expressed prostate secretions (EPS) are obtained during digital rectal examination (DRE), a daily routine urological diagnostic procedure, following massage of the prostate.

Materials and Methods. Urethral swabs and EPS samples were obtained from a consecutive sample of 752 men (mean age 32.4 years; median life-time sex partners 34) visiting urology outpatient clinics in St. Petersburg, Russia and tested for HPV DNA by general primer PCR, followed by genotyping using Luminex.

Results. Overall, 47.9\% (360/752) of men were HPV-positive, with 42.0\% (316/752) being positive for high-risk (HR-) HPV and 12.6\% (95/752) for multiple HPV types. HPVpositivity in the EPS samples was 32.6\% (27.7\% HR-HPV) and in the urethral samples 25.9\% (24.5\% HR-HPV). 10.6\% were HPV positive in both EPS and urethral samples. 6.4\% had the same HPV-type in both EPS and urethral samples. 10.6\% were HPV positive in both EPS and urethral samples. 6.4\% had the same HPV-type in both EPS and urethral samples. The concordance between the urethral samples and EPS was 62.5\% (470/752), with 80 cases double positive and 390 cases double negative in both sites. The sensitivity of urethral samples for overall HPV detection was 54.2\% (195/360). Compared to analysis of urethral samples only, the analysis of EPS increased the HPV prevalence in this population with $26.2 \%$.
\end{abstract}

Conclusion. EPS represent informative sampling material for the study of HPV epidemiology in the male. 


\section{Introduction}

Studies of the epidemiology of Human Papillomavirus (HPV) infection in the male are essential for understanding HPV natural history, transmission dynamics and optimal uses of HPV vaccines. Research on optimal methods and anatomical sites for sampling are essential for enabling informative studies.

A variety of different anatomical sites in men have been studied, including glans penis, prepuce, penile shaft, distal urethra, anal canal, perianal area, scrotum, semen and urine (1-5), but prostate secretions have to our knowledge not been studied so far. Expressed prostate secretion (EPS) is obtained during digital rectal examination (DRE, a daily routine urological diagnostic procedure) following massage of the prostate, and could thus represents a convenient new type of sample for studies of the epidemiology of HPV in the male.

EPS has been commonly used in urology ever since the Meares-Stamey 4-glass test, which included a quantitative culture of pure EPS, was launched in 1968 (6) and became the gold standard for assessing the bacteriological and inflammatory state of the lower urinary tract in urological patients. The two-glass or pre-post-massage screening test (7, 8) is recommended by European Association of Urology to differentiate between bacterial prostatitis and chronic pelvic pain syndrome in patients with prostatitis-like symptoms, if an acute urogenital infection and STD can be ruled out (9).

More than 155 different HPV types have been identified and are referred to by number (10).

Efficient genotyping can be achieved using bead-based multiplex genotyping (11) of PCR amplimers obtained following general primer PCR (12). A modified general primer (MGP) system was established as a modification of the classical HPV general primer system GP5+/6+ and found to result in an improved and more uniform analytical sensitivity for different HPV types (12). The system has also been validated using the WHO HPV DNA genotyping proficiency panel $(13,14)$.

Using the multiplexed genotyping method, we explored whether HPV was detectable in EPS and whether analysis of EPS would yield any additional information compared to analysis of samples from the distal urethra. 


\section{Materials and Methods}

\section{Study design}

A consecutive series of men who were visiting for STD testing in the urology units of two university outpatient clinics and a large clinic that provides testing for HIV and STDs to the general population in St. Petersburg were invited to participate in the study from May 2006 to February 2009. A total of 760 men, aged 18-60 (mean age 31.7) years, were enrolled after receiving a written instruction and providing written informed consent. The institutional review board of St. Petersburg State University and Medical Academy of Postgraduate Studies (North-Western State Medical University named after I.I. Mechnikov since 2011) approved the study.

\section{Procedure}

A urologist obtained a detailed medical history and performed a physical examination, including DRE. We also collected data on lifestyle and sexual behaviors, such as age at first intercourse, number of lifetime sex partners, sex preferences, and STDs history. All men provided blood samples for HIV and Treponema pallidum testing. In men over 40 years, prostate-specific antigen (PSA) testing was also performed.

Before sampling, men were instructed to abstain from any form of sex for 3-5 days and from urination for 3-4 hours.

The study clinician sampled the urethra with a urethral swab. Once inserted into the urethra, the swab was rotated $180^{\circ}$ right- and leftwards. Then the swab was rinsed in $1000 \mu \mathrm{l}$ of phosphate buffer in two separate tubes. The first sample was used for detection for STDs, such as Chlamydia trachomatis, Neisseria gonorrhea, Trichomonas vaginalis, and herpes simplex virus (HSV) types 1 and 2 at the local laboratory, while the second sample was stored at $-20^{\circ} \mathrm{C}$ prior to HPV testing.

After urethral sampling, the man was asked to urinate.

Afterwards a DRE with massage of the prostate was performed. The EPS was allowed to drop freely out of the urethra directly into a separate tube, which was also stored at $20^{\circ} \mathrm{C}$ prior to HPV testing. 


\section{Detection and typing of HPV}

HPV testing of urethral and EPS samples was conducted using PCR amplification of a fragment in the L1 gene (12). DNA was released using a freeze-thaw-boil procedure, as described (15). In brief, 100 ? l the sample was centrifuged and reconstituted in 100 ? l of TE-buffer $\mathrm{pH}$ 7.5. This sample was boiled at $107^{\circ} \mathrm{C}$ degrees for 10 minutes, after which it was frozen at $-20^{\circ} \mathrm{C}$ degrees. The quality of the sample DNA for amplification was analysed using a $\beta$-globin real-time PCR using $5 \mu \mathrm{l}$ of the sample in a 25 ?l reaction (16). Samples testing $\beta$-globin negative were treated with SDS/Proteinase $\mathrm{K}$ over night as described (16) and the real-time PCR repeated. $\beta$-globin was detected in 98.9\% (1504/1520) of the urogenital samples. Eleven still $\beta$-globin negative samples ( 3 urethral and 8 prostate, 8 men in total) were excluded from the present study. Complete urethral and prostate paired sample sets could thus be obtained from 752 men. Samples were tested for the presence of HPV by amplifying $5 \mu$ l of DNA with the MGP primer system, as described (12). HPV detection and genotyping was conducted on the Bioplex 200 Luminex system (BioRad, Hercules, CA, USA) using multiplex bead-based hybridization with Luminex technology as described by Schmitt et al (11). In brief, $10 \mu \mathrm{l}$ of the biotinylated MGP-PCR products were mixed with beads coupled with different HPV probes, after 10 minutes denaturation at $95^{\circ} \mathrm{C}$ the samples were incubated at $41^{\circ} \mathrm{C}$ for 30 minutes. After washing, streptavidin-R-phycoerythrin was incubated with the samples for 30 minutes at room temperature. 100 beads of each HPV type from each sample were analysed using the Luminex system. The probes for 14 oncogenic (high-risk, HR-HPV) types $(16,18,31,33$, $35,39,45,51,52,56,58,59,66,68 \mathrm{a}$ and $68 \mathrm{~b}$, including probes for variant sequences of HPV-18, 35, 51 and 58) and 22 non-oncogenic types including low-risk and possible highrisk types $(6,11,26,30,40,42,43,53,54,61,67,70,73,74,81,82,83,86,87,89,90$ and 91) were used. Eleven negative controls $\left(\mathrm{H}_{2} \mathrm{O}\right)$ and 8 positive controls (HPV plasmid pools) were run on every PCR and Luminex plate.

\section{Statistical analysis}

HPV and HR-HPV concordance was calculated as the proportion of men double positive or double negative for both urethra and prostate specimens as compared to the full cohort. Comparisons of HPV prevalences and determinants of HPV infection used 
binomial logistic regression to calculate odd-ratios (ORs) and their confidence intervals (95\%CI) using the statistical software R (R Development, Core, Team. R: A language and environment for statistical computing. R Foundation for Statistical Computing. 2010; Available from: http://www.R-project.org).

\section{Results}

Among the 752 men tested, the HPV prevalences were 25.9\% (195/752) in the urethral samples and 32.6\% (245/752) in the EPS samples. Oncogenic HPV infections (HR-HPV) were found in $24.5 \%$ (184/752) and 27.7\% (208/752) of the urethral and EPS samples, respectively.

Combining urethral and EPS samples resulted in an overall 47.9\% HPV-positivity in the studied population, twice as much as seen when analyzing only samples from the distal urethra. Similarly, the combined prevalence for oncogenic (high-risk, HR-HPV) and multiple HPV infection was $42.0 \%$ and $12.6 \%$, respectively (Table 1 ).

The 5 most common HPV types were HPV-16 (17.2\%), HPV-66 (5.1\%), HPV-45 (4.4\%), HPV-87 (3.9\%) and HPV-6 (3.2\%). In the male distal urethra the 5 most common HPV types were HPV-16 (8.9\%), followed by HPV-18, -45, -51 and -6 (3.2\%, 2.8\%, 2.3\% and 2,1\%), whereas the 5 most common types were HPV-16 (10.8\%), followed by HPV-66, $87,-45$ and -91 (4.1\%, 3.9\%, 2.7\% and 2.1\%) in the prostate secretion specimens. Three of the HPV types tested for were not detected in any sample (HPV-26, -54 and -61). Single HPV infections were found in $20.8 \%(n=156)$ of urethral and $24.5 \%(n=184)$ of prostate samples but only 44 men (4.9\%) were positive for the same single HPV type in both types of samples (Table 1). Multiple HPV infections were common, found in $12.0 \%(n=90)$ of the men. Multiple HPV infections were less common in the distal urethra (5.2\%) than in the prostate secretion (8.1\%) specimens ( $\mathrm{p}=0.002)$. Up to 5 concomitant HPV infections were seen in urethral samples and up to 4 in the EPS. Up to 3 concomitant HR-HPV types could be present in both sites.

HR-HPV infection tended to be more common and LR-HPV infection was significantly more common in the EPS than in the urethral samples $(p=0.06$ and $p=0.0003$, respectively). 
Table 1. Detection of human papillomavirus (HPV) infection in the male distal urethra as compared to in expressed prostate secretions.

\begin{tabular}{|c|c|c|c|c|}
\hline HPV types & $\begin{array}{c}\text { Urethra } \\
\text { (\%) }\end{array}$ & $\begin{array}{c}\text { Prostate } \\
\text { (\%) }\end{array}$ & $\begin{array}{c}\text { Urethra or } \\
\text { Prostate (\%) }\end{array}$ & $\begin{array}{l}\text { Urethra and } \\
\text { Prostate (\%) }\end{array}$ \\
\hline 6 & $16(2.1)$ & $8(1.1)$ & $24(3.2)$ & 0 \\
\hline 11 & $2(0.3)$ & $4(0.5)$ & $6(0.8)$ & 0 \\
\hline 16 & $67(8.9)$ & $81(10.8)$ & $129(17.2)$ & $19(2.5)$ \\
\hline 18 & $24(3.2)$ & $10(1.3)$ & $31(4.1)$ & $3(0.4)$ \\
\hline 26 & 0 & 0 & 0 & 0 \\
\hline 30 & $4(0.5)$ & $6(0.8)$ & $10(1.3)$ & 0 \\
\hline 31 & $1(0.1)$ & $3(0.4)$ & $3(0.4)$ & $1(0.1)$ \\
\hline 33 & $2(0.3)$ & $1(0.1)$ & $3(0.4)$ & 0 \\
\hline 35 & $3(0.4)$ & $7(0.9)$ & $10(1.3)$ & 0 \\
\hline 39 & 0 & $3(0.4)$ & $3(0.4)$ & 0 \\
\hline 40 & $1(0.1)$ & $5(0.7)$ & $6(0.8)$ & 0 \\
\hline 42 & $8(1.1)$ & $9(1.2)$ & $15(1.9)$ & $2(0.3)$ \\
\hline 43 & $6(0.8)$ & $5(0.7)$ & 11 (1.5) & 0 \\
\hline 45 & $21(2.8)$ & $20(2.7)$ & $35(4.4)$ & $6(0.7)$ \\
\hline 51 & $17(2.3)$ & $9(1.2)$ & $25(3.3)$ & $1(0.1)$ \\
\hline 52 & $5(0.7)$ & $9(1.2)$ & 13 (1.7) & $1(0.1)$ \\
\hline 53 & $3(0.4)$ & $5(0.7)$ & $6(0.8)$ & $2(0.3)$ \\
\hline 54 & 0 & 0 & 0 & 0 \\
\hline 56 & $2(0.3)$ & $6(0.8)$ & $8(1.1)$ & 0 \\
\hline 58 & $2(0.3)$ & $5(0.7)$ & $6(0.8)$ & $1(0.1)$ \\
\hline 59 & $11(1.5)$ & $7(0.9)$ & $16(2.1)$ & $2(0.3)$ \\
\hline 61 & 0 & 0 & 0 & 0 \\
\hline 66 & $11(1.5)$ & $31(4.1)$ & $38(5.1)$ & $4(0.5)$ \\
\hline 67 & $4(0.5)$ & $6(0.8)$ & $9(1.2)$ & $1(0.1)$ \\
\hline 68 & 0 & $1(0.1)$ & $1(0.1)$ & 0 \\
\hline 70 & $1(0.1)$ & $5(0.7)$ & $6(0.8)$ & 0 \\
\hline 73 & $1(0.1)$ & 0 & $1(0.1)$ & 0 \\
\hline 74 & $5(0.7)$ & $12(1.6)$ & $17(2.3)$ & 0 \\
\hline 81 & $3(0.4)$ & $3(0.4)$ & $6(0.8)$ & 0 \\
\hline 82 & $2(0.3)$ & $1(0.1)$ & $3(0.4)$ & 0 \\
\hline 83 & 0 & $1(0.1)$ & $1(0.1)$ & 0 \\
\hline 86 & $1(0.1)$ & $2(0.3)$ & $3(0.4)$ & 0 \\
\hline 87 & $10(1.3)$ & $21(2.8)$ & $29(3.9)$ & $2(0.3)$ \\
\hline 89 & 0 & $3(0.4)$ & $3(0.4)$ & 0 \\
\hline 90 & $2(0.3)$ & $7(0.9)$ & $9(1.2)$ & 0 \\
\hline 91 & $8(1.1)$ & $16(2.1)$ & $21(2.8)$ & $3(0.4)$ \\
\hline HPV+ men, in total & $195(25.9)$ & $245(32.6)$ & $360(47.9)$ & $80(10.6)$ \\
\hline HPV-men, in total & $557(74.1)$ & 507 (67.4) & $674(89.6)$ & $390(51.9)$ \\
\hline HR-HPV+ men & $184(24.5)$ & $208(27.7)$ & $316(42.0)$ & $76(10.1)$ \\
\hline LR-HPV+ men & $81(10.8)$ & $125(16.6)$ & $189(25.1)$ & $17(2.3)$ \\
\hline Single HPV infection & $156(20.8)$ & $184(24.5)$ & $296(39.4)$ & $44(4.9)$ \\
\hline Multiple HPV infection & $39(5.2)$ & $61(8.1)$ & $95(12.6)$ & $5(0.7)$ \\
\hline No. studied men, total & \multicolumn{4}{|c|}{752} \\
\hline
\end{tabular}


HPV concordance between the distal urethra and prostate secretions specimens obtained from the same men was low: $10.6 \%(n=80)$ for all HPV, $10.1 \%(n=76)$ for HRHPV and 2.3\% $(\mathrm{n}=17)$ for LR-HPV types, respectively, with only $6.4 \%(\mathrm{n}=48)$ and $5.1 \%$ $(n=38)$ being concordant based on exactly the same HPV or HR-HPV type, respectively. The sensitivity of urethral samples for overall HPV detection was 54.2\% (195/360).

Table 2. Factors associated with detection of human papillomavirus (HPV) in the male urethra and expressed prostate secretions (EPS): Multivariate Analysis.

\begin{tabular}{|c|c|c|c|c|c|c|c|}
\hline \multicolumn{2}{|c|}{ Factor } & \multicolumn{3}{|c|}{ Urethra } & \multicolumn{3}{|c|}{ EPS } \\
\hline & & $\begin{array}{l}\text { Number of } \\
\mathrm{HPV}+ \\
\text { men/total } \\
\text { tested }\end{array}$ & OR (95\%CI) & P-value & $\begin{array}{l}\text { Number of } \\
\mathrm{HPV}+ \\
\text { men/total } \\
\text { tested }\end{array}$ & OR $(95 \% \mathrm{CI})$ & $\mathrm{P}$-value \\
\hline \multirow{5}{*}{$\begin{array}{l}\text { Age at the } \\
\text { study time, } \\
\text { years }\end{array}$} & $18-24$ & $43 / 140$ & \multicolumn{2}{|l|}{ Ref } & $39 / 140$ & \multicolumn{2}{|l|}{ Ref } \\
\hline & $25-29$ & $53 / 187$ & $\begin{array}{l}0.3 \\
(0.1-0.93)\end{array}$ & 0.04 & $66 / 187$ & $\begin{array}{l}0.26 \\
(0.09-0.75)\end{array}$ & 0.01 \\
\hline & $30-34$ & $48 / 190$ & $\begin{array}{l}0.32 \\
(0.12-0.84)\end{array}$ & 0.02 & $60 / 190$ & $\begin{array}{l}0.33 \\
(0.14-0.81)\end{array}$ & 0.02 \\
\hline & $35-39$ & $27 / 107$ & $\begin{array}{l}0.73 \\
(0.24-2.24)\end{array}$ & 0.59 & $39 / 107$ & $\begin{array}{l}0.52 \\
(0.18-1.53)\end{array}$ & 0.24 \\
\hline & $40+$ & $31 / 117$ & $\begin{array}{l}0.05 \\
(0.01-0.48)\end{array}$ & 0.009 & $37 / 117$ & $\begin{array}{l}0.08 \\
(0.02-0.43)\end{array}$ & 0.003 \\
\hline \multirow{3}{*}{$\begin{array}{l}\text { Age when } \\
\text { sex life } \\
\text { began, } \\
\text { years }\end{array}$} & $<16$ & $42 / 135$ & \multicolumn{2}{|l|}{ Ref } & $53 / 135$ & \multicolumn{2}{|l|}{ Ref } \\
\hline & $16-19$ & $128 / 464$ & $\begin{array}{l}1.18 \\
(0.42-3.29)\end{array}$ & 0.77 & $136 / 464$ & $\begin{array}{l}1.31 \\
(0.51-3.51)\end{array}$ & 0.58 \\
\hline & $20+$ & $31 / 141$ & $\begin{array}{l}2.95 \\
(0.75-11.55)\end{array}$ & 0.12 & $53 / 141$ & $\begin{array}{l}2.37 \\
(0.66-8.53)\end{array}$ & 0.19 \\
\hline \multirow{4}{*}{$\begin{array}{l}\text { Number of } \\
\text { life-time } \\
\text { sex } \\
\text { partners }\end{array}$} & $0-5$ & $36 / 151$ & \multicolumn{2}{|l|}{ Ref } & $44 / 151$ & \multicolumn{2}{|l|}{ Ref } \\
\hline & $6-10$ & $45 / 180$ & $\begin{array}{l}0.7 \\
(0.21-2.35)\end{array}$ & 0.57 & $48 / 180$ & $\begin{array}{l}0.91 \\
(0.27-2.88)\end{array}$ & 0.87 \\
\hline & $11-20$ & $40 / 150$ & $\begin{array}{l}1.0 \\
(0.3-3.31)\end{array}$ & 1.0 & $52 / 150$ & $\begin{array}{l}1.21 \\
(0.38-3.83)\end{array}$ & 0.74 \\
\hline & $21+$ & $81 / 259$ & $\begin{array}{l}1.04 \\
(0.32-3.32)\end{array}$ & 0.95 & $95 / 259$ & $\begin{array}{l}1.49 \\
(0.49-4.54)\end{array}$ & 0.48 \\
\hline \multirow{2}{*}{$\begin{array}{l}\text { Any STDs } \\
\text { present }\end{array}$} & $\begin{array}{l}\text { Not } \\
\text { detected }\end{array}$ & $227 / 709$ & \multicolumn{2}{|l|}{ Ref } & $256 / 709$ & Ref & \\
\hline & Detected & $14 / 47$ & $\begin{array}{l}1.45 \\
(0.63-3.36)\end{array}$ & 0.38 & $20 / 47$ & $\begin{array}{l}1.3 \\
(0.59-2.88)\end{array}$ & 0.52 \\
\hline \multirow{2}{*}{$\begin{array}{l}\text { History of } \\
\text { treated } \\
\text { Chlamydia } \\
\text { infection }\end{array}$} & Never & $126 / 504$ & \multicolumn{2}{|l|}{ Ref } & $156 / 504$ & \multicolumn{2}{|l|}{ Ref } \\
\hline & Reported & $76 / 237$ & $\begin{array}{l}1.06 \\
(0.44-2.54)\end{array}$ & 0.89 & $86 / 237$ & $\begin{array}{l}0.99 \\
(0.44-2.23)\end{array}$ & 0.99 \\
\hline \multirow{2}{*}{$\begin{array}{l}\text { Pain } \\
\text { syndrome }\end{array}$} & No & $146 / 506$ & \multicolumn{2}{|l|}{ Ref } & $181 / 506$ & \multicolumn{2}{|l|}{ Ref } \\
\hline & Yes & $59 / 212$ & $\begin{array}{l}0.82 \\
(0.38-1.79)\end{array}$ & 0.63 & $64 / 212$ & $\begin{array}{l}0.81 \\
(0.39-1.67)\end{array}$ & 0.57 \\
\hline
\end{tabular}


We found only one determinant of the HPV prevalences, namely a lower HPV prevalence with increasing age. This was found both for urethral $(p=0.009)$ and EPS $(\mathrm{p}=0.003)$ samples. HPV prevalence was not significantly related to the life-time number of sexual partners (Table 2).

Genital warts were found in $7(0.9 \%)$ men in total; all of them were visibly presented on penile heads. The urethral swabs were negative for HPV infections for 5 of these men and 2 of the EPS samples were also negative.

Recently diagnosed STDs were present in 47 (6.3\%) males: HIV in one (0.1\%), HSV in 3 $(0.4 \%)$ and $C$. trachomatis in $43(5.7 \%)$ men with one $(0.1 \%)$ positive case for $N$. gonorrhea among them. The HIV-positive man had multiple HPV infections (HPV types $16,-30,-33,-42$ and -45 in the urethra and HPV-42 in the EPS). In the single case of gonococcal urethritis, HPV-91 was detected in both samples. Treatment against $C$. trachomatis infection in the past was reported by $31.5 \%$ (237) of the men. Only 10 (1.3\%) men reported practicing sex with other men. There were no differences in HPV prevalences in relation to STD history, neither for urethral nor for prostate specimens (Table 2).

\section{Discussion}

Prostate secretions were found to represent an informative sample material for the study of HPV epidemiology in the male, greatly increasing the number of HPV-positive cases as compared to the study of samples from the distal urethra. The concomitant study of EPS and urethral swabs was necessary in order to answer the question whether virus presence in the EPS may be derived from the urethra when the EPS is transported through the urethra. To minimize urethral contamination of the EPS samples, the men were asked to urinate between collecting samples, as is the recommended procedure for urological patients $(7,8)$. As many EPS samples contained HPV also when the urethral samples were negative and as the HPV type-concordance was limited, most of the presence of HPV in the EPS samples is unlikely to be derived from the distal urethra. Although the prostate epithelium thus seems like the most likely source of the HPV found in the EPS, we cannot exclude that it may derive from adjacent anatomical structures, such as the seminal vesicles. 
Semen samples have shown only low HPV prevalences (3), although EPS is a part of the ejaculate. Possible reasons for this discrepancy include different study populations, as a very high sexual risk taking population would be more likely to be HPV-positive and/or that EPS may be more diluted in semen. Compared to semen, EPS is more suitable for epidemiological studies as it is readily obtained during a single, routine visit.

This is the first and only study where multiplex high-throughput genotyping of an extended spectrum of HPV types was performed on prostate secretion samples, analyzed and compared with the paired distal urethra samples obtained from the same men, representing the male upper and lower urogenital tract, respectively.

A limitation of our study was that we did not compare the HPV prevalences in EPS to the HPV prevalences in samples from various parts of the body, such as penile or anal swabs. Penile swabs are reported to be the anatomic site with the highest published prevalence of HPV (17). The aim of our study was merely to explore whether HPV would be commonly present in EPS and, if so, whether the presence of HPV in EPS could be explained by contamination from the distal urethra. Although our data indicate that EPS is an informative sample that should be considered for inclusion in comprehensive studies of HPV epidemiology of the male, the question of how it compares to all other possible samples and which panel of samples to include will need to be answered by future studies.

Prostate cancer is the most common non-cutaneous cancer among males (18). Chronic inflammation of the prostate and history of STDs are among the factors speculated to be part of prostate carcinogenesis (19-25). A possible involvement of HPV was suggested by a seroepidemiological study (26), but different studies found inconsistent associations with different HPV types and the original association was attributed to chance, bias, or confounding by some unknown risk factor that may associate with different HPV infections in different populations (27).

Studies of HPV DNA detection in prostate cancer tissue have been controversial. Although some studies have found HPV DNA (28-30) others did not (31-33). In the current study, HPV DNA in EPS samples was found to be less common among men above 40 years of age. Absence of HPV DNA in prostate cancers, which occur among the elderly, does therefore not contradict the possibility that HPV may infect prostatic epithelium among younger, sexually active men. 
A high number of female sex partners is a major risk factor for male acquisition of genital HPV infection (34-36), but this was not detected in the present study. A possible explanation is that the studied cohort had such a high number of sexual partners that also the reference category of men (who had less than 6 life-time partners) was already highly exposed.

HPV infection in men is often asymptomatic, resulting in a large number of asymptomatic carriers (37), and can clear spontaneously. HPV infection rates in males have been reported to range from $1.3 \%$ to $72.9 \%$, with prevalences being dependent on the sampling and processing methods as well as the anatomic sites sampled $(1,17)$. Penile and urethral brushings have been recommended as the most accurate method (or penile brushing and semen as an alternative) for HPV DNA detection in men (2). However, that study was based only on 50 subjects [2]. A larger study on PCR detection of HPV in the urethra, different parts of penis, scrotum, perianal area and anal canal, semen and urine in 463 men found an overall HPV prevalence of $65.4 \%$. Sampling from the penile shaft, glans penis/coronal sulcus and scrotum in heterosexual men was recommended (3). In our study of 752 men, the HPV prevalences were $25.9 \%$ in the male distal urethra and $32.6 \%$ in the prostate secretion specimens resulting in an overall $47.9 \%$ of HPV-positivity. Because deep urethral sample collection is painful, selection of a convenient combination of samples that would still be able to detect most of the HPV infections in the study subjects is a challenge (3). EPS tested alone or in a combination with urethral swabs might not provide the complete picture of overall HPV prevalence in a male, but it will broaden our knowledge on HPV epidemiology in the male urogenital tract, especially in some targeted populations (urological patients, elderly men, vaccinated people etc.) and, because of the presence of EPS in the ejaculate, the study of EPS is of particular interest in studies of the transmission of HPV to the sexual partner(s). Other studies where EPS might be of interest are to improve the diagnostics of HPV infection in men, studies monitoring the effect of HPV vaccination and studies of HPV infection in men with and without inflammatory processes in the prostate.

In summary, we find that expressed prostate secretions are commonly positive for HPV infections that are not detectable in urethral swabs. Continued studies using EPS might allow for a better understanding of HPV epidemiology and natural history, its involvement in the urological diseases in the male as well as its transmission to the sexual partner. 


\section{Acknowledgments}

The authors are grateful to the personnel of the Laboratory of Microbiology, D.O. Ott Research Institute of Obstetrics and Gynecology and St. Petersburg State University outpatient clinic (St. Petersburg, Russia) for their dedicated technical and administrative support.

\section{References}

1. Bleeker MC, Hogewoning CJ, Berkhof J, Voorhorst FJ, Hesselink AT, et al. (2005)

Concordance of specific human papillomavirus types in sex partners is more prevalent than would be expected by chance and is associated with increased viral loads. Clin Infect Dis 41: 612-620.

2. Giovannelli L, Bellavia C, Capra G, Migliore MC, Caleca M, et al. (2007) HPV group- and type-specific concordance in HPV infected sexual couples. J Med Virol 79: 1882-1888.

3. Giuliano AR, Nielson CM, Flores R, Dunne EF, Abrahamsen M, et al. (2007) The optimal anatomic sites for sampling heterosexual men for human papillomavirus (HPV) detection: the HPV detection in men study. J Infect Dis 196: 1146-1152.

4. Nyitray A, Nielson CM, Harris RB, Flores R, Abrahamsen M, et al. (2008) Prevalence of and risk factors for anal human papillomavirus infection in heterosexual men. J Infect Dis 197: 1676-1684.

5. Vardas E, Giuliano AR, Goldstone S, Palefsky JM, Moreira ED Jr, et al. (2011)
External genital human papillomavirus prevalence and associated factors among heterosexual men on 5 continents. J Infect Dis 203: 58-65.

6. Meares EM, Stamey TA (1968) Bacteriologic localization patterns in bacterial prostatitis and urethritis. Invest Urol 5: 492-518.

7. Nickel JC. 1998. Effective office management of chronic prostatitis. Urol Clin North Am 25: 677-684.

8. Nickel JC, Shoskes D, Wang Y, Alexander RB, Fowler JE Jr, et al. (2006) How does the pre-massage and post-massage 2glass test compare to the MearesStamey 4-glass test in men with chronic prostatitis/chronic pelvic pain syndrome? J Urol 176: 119-124.

9. Fall M, Baranowski AP, Elneil S, Engeler D, Hughes J, et al. (2010) EAU guidelines on chronic pelvic pain. Eur Urol 57: 3548.

10. Bernard HU, Burk RD, Chen Z, van Doorslaer K, Hausen H, et al. (2010) Classification of papillomaviruses (PVs) based on 189 PV types and proposal of taxonomic amendments. Virology 401: 70-79. 
11. Schmitt M, Bravo IG, Snijders PJ, Gissmann L, Pawlita M, et al. (2006) Bead-based multiplex genotyping of human papillomaviruses. J Clin Microbiol 44: 504-512.

12. Söderlund-Strand A, Carlson J, Dillner J (2009) Modified general primer PCR system for sensitive detection of multiple types of oncogenic human papillomavirus. J Clin Microbiol 47: 541546.

13. Eklund C, Zhou T, Dillner J; WHO Human Papillomavirus Laboratory Network (2010) Global proficiency study of human papillomavirus genotyping. J Clin Microbiol 48: 4147-4155.

14. Eklund C, Forslund O, Wallin KL, Zhou T, Dillner J; WHO Human Papillomavirus Laboratory Network (2012) The 2010 global proficiency study of human papillomavirus genotyping in vaccinology. J Clin Microbiol 50: 22892298.

15. Forslund O, Antonsson A, Edlund K, van den Brule AJ, Hansson BG, et al. (2002) Population-based type-specific prevalence of high-risk human papillomavirus infection in middle-aged Swedish women. J Med Virol 66: 535541.

16. Söderlund-Strand A, Eklund C, Kemetli L, Grillner L, Törnberg S, et al. (2011) Genotyping of human papillomavirus in triaging of low-grade cervical cytology. Am J Obstet Gynecol 205: 145.

17. Dunne EF, Nielson CM, Stone KM, Markowitz LE, Giuliano AR (2006) Prevalence of HPV infection among men:
A systematic review of the literature. J Infect Dis 194: 1044-1057.

18. Jemal A, Siegel R, Ward E, Hao Y, Xu J, et al. (2009) Cancer statistics, 2009. CA Cancer J Clin 59: 225-249.

19. Nelson WG, De Marzo AM, DeWeese TL, Isaacs WB (2004) The role of inflammation in the pathogenesis of prostate cancer. J Urol 172: S6-11.

20. Sutcliffe S, Zenilman JM, Ghanem KG, Jadack RA, Sokoll LJ, et al. (2006) Sexually transmitted infections and prostatic inflammation/cell damage as measured by serum prostate specific antigen concentration. J Urol 175: 1937 1942.

21. Sutcliffe S, Giovannucci E, De Marzo AM, Leitzmann MF, Willett WC, et al. (2006) Gonorrhea, syphilis, clinical prostatitis, and the risk of prostate cancer. Cancer Epidemiol Biomarkers Prev 15: 2160 2166.

22. Goldstraw MA, Fitzpatrick JM, Kirby RS (2007) What is the role of inflammation in the pathogenesis of prostate cancer? BJU Int 99: 966-968.

23. Wagenlehner FM, Elkahwaji JE, Algaba F, Bjerklund-Johansen T, Naber KG, et al. (2007) The role of inflammation and infection in the pathogenesis of prostate carcinoma. BJU Int 100: 733-737.

24. Cheng I, Witte JS, Jacobsen SJ, Haque R, Quinn VP, et al. (2010) Prostatitis, sexually transmitted diseases, and prostate cancer: the California Men's Health Study. PLoS One 5: e8736.

25. Taylor ML, Mainous AG 3rd, Wells BJ (2005) Prostate cancer and sexually 
transmitted diseases: a meta-analysis.

Fam Med 37: 506-512.

26. Dillner J, Knekt P, Boman J, Lehtinen M, Af Geijersstam V, et al. (1998) Seroepidemiological association between human-papillomavirus infection and risk of prostate cancer. Int J Cancer 75: 564-567.

27. Adami HO, Kuper H, Andersson SO, Bergström R, Dillner J (2003) Prostate cancer risk and serologic evidence of human papilloma virus infection: a population-based case-control study. Cancer Epidemiol Biomarkers Prev 12: 872-875.

28. Leiros GJ, Galliano SR, Sember ME, Kahn T, Schwarz E, et al. (2005) Detection of human papillomavirus DNA and p53 codon 72 polymorphism in prostate carcinomas of patients from Argentina. BMC Urol 5: 15.

29. Carozzi F, Lombardi FC, Zendron P, Confortini M, Sani C, et al. (2004) Association of human papillomavirus with prostate cancer: analysis of a consecutive series of prostate biopsies. Int J Biol Markers 19: 257-261.

30. Zambrano A, Kalantari M, Simoneau A, Jensen JL, Villarreal LP (2002) Detection of human polyomaviruses and papillomaviruses in prostatic tissue reveals the prostate as a habitat for multiple viral infections. Prostate 53: 263-276.

31. Strickler HD, Burk R, Shah K, Viscidi R, Jackson A, et al. (1998) A multifaceted study of human papillomavirus and prostate carcinoma. Cancer 82: 11181125.

32. Leskinen MJ, Vainionp R, Syrjnen S, Leppilahti M, Marttila T, et al. (2003) Herpes simplex virus, cytomegalovirus, and papillomavirus DNA are not found in patients with chronic pelvic pain syndrome undergoing radical prostatectomy for localized prostate cancer. Urology 61: 397-401.

33. Smelov V, van Moorselaar J, Startsev V, Smelova N, Grigorovich E, et al. (2011) No high-risk human papillomavirus infection in prostate cancer tissues. Scand J Infect Dis 43: 399-400.

34. Franceschi S, Castellsagué X, Dal Maso L, Smith JS, Plummer M, et al. (2002) Prevalence and determinants of human papillomavirus genital infection in men. Br J Cancer 86: 705-711.

35. Svare EI, Kjaer SK, Worm AM, Osterlind A, Meijer CJ, et al. (2002) Risk factors for genital HPV DNA in men resemble those found in women: a study of male attendees at a Danish STD clinic. Sex Transm Infect 78: 215-218.

36. Nielson CM, Harris RB, Dunne EF, Abrahamsen M, Papenfuss MR, et al. (2007) Risk factors for anogenital human papillomavirus infection in men. J Infect Dis 196: 1137-1145.

37. Baldwin SB, Wallace DR, Papenfuss MR, Abrahamsen M, Vaught LC, et al. (2003) Human papillomavirus infection in men attending a sexually transmitted disease clinic. J Infect Dis 187: 1064-1070. 



\section{Chapter 7}

Prevalence of cutaneous

beta and gamma

human papillomaviruses

in the anal canal of

men who have sex with women 


\title{
Prevalence of cutaneous beta and gamma human papillomaviruses in the anal canal of men who have sex with women
}

\author{
Vitaly Smelov ${ }^{1,2,4,5^{*}}$, Rachel Hanisch ${ }^{3}$, \\ Sandrine McKay-Chopin¹, Olga Sokolova6,7, \\ Carina Eklund5, Boris Komyakov4, \\ Tarik Gheit ${ }^{1}$, Massimo Tommasino ${ }^{1}$
}

Papillomavirus Res. 2017 Jun;3:66-72.

${ }^{1}$ Infections and Cancer Biology Group, International Agency for Research on Cancer, World Health Organization, Lyon, France; ${ }^{2}$ Screening Group, International Agency for Research on Cancer, World Health Organization, Lyon, France; ${ }^{3}$ Section of Environment and Radiation, International Agency for Research on Cancer, World Health Organization, Lyon, France; ${ }^{4}$ Department of Urology, North-Western State Medical University named after I.I. Mechnikov, St. Petersburg, Russia; ${ }^{5}$ Department of Laboratory Medicine, Karolinska Institutet, Stockholm, Sweden; ${ }^{6}$ Faculty of Medicine, St. Petersburg State University, St. Petersburg, Russia; 7 Clinical Infectious Diseases Hospital named after S.P. Botkin, St. Petersburg, Russia. 


\title{
Highlights
}

- $\beta$ and $\gamma$ HPV types commonly colonize the anal canal of men who have sex with women, but their geographical variation in prevalence could be wide.

- HIV-positive men were more likely to have both genera of HPV types detected.

- Routes other than penile-anal intercourse may be important in cutaneous HPV transmission.

\begin{abstract}
Background. Data regarding anal cutaneous HPV detection among HIV-positive and HIVnegative persons largely relies on studies among men who have sex with men in limited geographical settings. Understanding the distribution, determinants, and potential human health effects of anal cutaneous HPV types among men who have sex with women (MSW) is important.

Methods. Anal canal swab samples from 415 Russian MSW (384 HIV-negative and 31 HIVpositive) were tested for $43 \beta$-HPVs and $29 \gamma$-HPVs, using a multiplex PCR combined with Luminex technology.

Results. $\beta$-HPV was detected in $24.4 \%$ and $\gamma$-HPV in $15.9 \%$ of anal samples of all Russian MSW. In total, $34 \beta$-HPV and $19 \gamma$-HPV types were detected, with the most commonly detected $\beta$-HPV types being 110, 22 and 124 and the most common $\gamma$-HPV types being 95, 132 and 50. For both genera, being HIV-positive at the time of testing was a significant determinant of detection (74.2\% for $\beta$-HPVs and $48.4 \%$ for $\gamma$-HPVs compared to $20.1 \%$ and $12.5 \%$ in HIV-negative MSW, respectively).

Conclusions. A wide spectrum and moderate prevalence of anal $\beta$-HPV and $\gamma$-HPV types was found in our MSW study sample, suggesting that routes other than penile-anal intercourse may be important in cutaneous HPV transmission.
\end{abstract}




\section{Introduction}

Human papillomaviruses (HPV) are a broad and diverse group of viruses which include types that infect the human mucosa and those that are present at anatomical cutaneous sites [1]. Currently, 205 HPV types have been identified [2], with the majority belonging to the Alphapapillomavirus ( $\alpha$ ), Betapapillomavirus ( $\beta$ ), and Gammapapillomavirus $(\gamma)$ genera, depending on their epithelial tropism [3]. Mucosal high-risk HPVs belonging to the $\alpha$-genus are known to be associated with the development of several types of cancer, including anogenital cancer [4]. There is some evidence of the oncogenic potential of non- $\alpha$ HPV,cutaneous types based on their proposed and speculated role in skin cancer (for $\beta$ HPVs [5-8] and $\gamma$-HPVs [9,10], respectively). However, compared to $\alpha$-HPVs, the distribution, etiology, and possible role of cutaneous types in the development of cancer is largely unknown.

Several recent studies among men who have sex with men (MSM) have described a high prevalence and broad spectrum of $\beta$ - and $\gamma$-HPVs in the anal canal [11-13]. Relatively little, however, was known about the prevalence of cutaneous HPVs among men who have sex with women (MSW) until a recent pair of publications using data from the HPV in men (HIM) study $[14,15]$. Data from this study not only suggested an equally high prevalence of $\beta$-HPV among both MSM and MSW, but their results also indicated a wide geographical variation in prevalence (65.6\% in Mexico vs 48.6\% in Brazil and 48.7\% in the US) [15].

Further, much of the mechanistic hypotheses regarding cutaneous HPV transmission to genital sites are speculative, and are based on studies among MSM and HIV+ populations. Among MSMs, it is thought that infection primarily occurs mechanistically via penile-anal insertion, as evidence points to the transmission of cutaneous HPV between anatomical sites [14]. However, HIM's recent findings that MSWs are equally likely to harbour $\beta$-HPV, strengthened by the lack of association between $\beta$-HPV prevalence and sexual behaviours, suggest that alternative transmission routes may exist. Further, among HIV+ individuals, molecular mechanisms are thought to potentiate HPV penetration into the epithelium, although a larger body of evidence is needed to better understand this process [16].

The number of studies on anal cutaneous HPVs is remarkably limited, and information on the anal presence and determinants of HPVs in males, especially among non-MSM populations, remains especially unclear. Therefore, the aim of the current retrospective 
study is to evaluate the prevalence of anal $\beta$ - and $\gamma$-HPVs in a large cohort of MSW from Russia, the first such known sample in the Eastern hemisphere.

\section{Methods}

\section{Study population}

We retrospectively analysed 415 DNA-positive anal samples obtained from MSWs as part of two clinic-based studies conducted in St. Petersburg, Russia. The first [17] was a pilot study investigating rectal Chlamydia LGV infection performed in an infectious disease hospital providing treatment for HIV+ MSM and MSW, from December 2005 to January 2006. The second [18] was conducted among men seeking routine STI testing at the urology units of two university outpatient clinics, from February 2006 to February 2009. Out of 558 men who were originally invited to participate, 545 agreed (38 infectious disease hospital; 507 urology clinic) (Figure 1). For the purposes of this study, 45 MSMs were excluded from analyses. Of the remaining 500 samples, 85 were found to be absent of $\beta$-globin, indicating no DNA was present in sample, leaving a total of 415 samples for analyses.

Men at both the infectious disease clinic and the urology clinic who were at least 18 years old (verified by clinic staff upon appointment registration) and who reported no anorectal disorders were invited to participate in the study upon entering the clinic exam room, after which time a medical history and a standard physical examination were completed. MSW versus MSM status was determined for all participants through selfreport of whether a man had had sex with another man during his lifetime (MSM) or not (MSW). Urological participants also completed a questionnaire concerning sexual behaviour (age at the time of sexual debut and number of lifetime sex partners); data on sexual behaviour were not available for infectious disease hospital participants.

HIV status was determined for infectious disease hospital patients by referring to the most recent test performed as part of their clinical care. For urology participants, a blood sample was taken for HIV testing at the time of enrollment. All participants having received an HIV+ test prior to this study were receiving HAART therapy at the time of enrollment.

All participants provided written informed consent, during which the anonymity of their data, especially in regards to its sexual nature, was stressed. The institutional review board 
of St. Petersburg Medical Academy of Postgraduate Studies approved the study. DNA samples and questionnaire data were anonymized, and no study personnel besides the principle investigator had access to participants' identifying information.

\section{Collection of samples and DNA extraction}

To sample the anal canal, a urethral brush wetted with phosphate buffered saline was inserted 1.5 to 2.0 centimetres from the anal verge of the canal and rotated $180^{\circ}$ to the right and left. The swab was removed from the anal canal and then rinsed in $1000 \mu \mathrm{l}$ of phosphate buffered saline in each of two separate tubes. The first sample was used for the detection of STIs, when applicable (MSM and HIV+ men). The second was placed in a refrigerator at $4^{\circ} \mathrm{C}$. At the end of the day, the samples were transferred to a $-20^{\circ} \mathrm{C}$ freezer and stored until HPV testing.

Using a $100 \mu \mathrm{l}$ aliquot of the original anal sample, DNA was extracted in the laboratory of the Department of Laboratory Medicine at Karolinska Institutet (Stockholm, Sweden), using a freeze-thaw-boil procedure, as previously described [19]. The frozen DNA samples were shipped on dry ice to the laboratory of the Group of Infections and Cancer Biology at IARC (Lyon, France) for $\beta$ - and $\gamma$-HPV-specific genotyping.

\section{Detection and genotyping of HPV}

Anal samples were tested for the presence of HPVs using type-specific polymerase chain reaction (PCR) bead-based multiplex genotyping (TS-MPG) assays that combine multiplex PCR and Luminex technology (Luminex Corp., Austin, TX, USA), as described elsewhere [15,20-24]. The multiplex type-specific PCR method uses specific primers for the detection of $43 \beta$-HPVs (species $\beta$-1: 5, 8, 12, 14, 19, 20, 21, 24, 25, 36, 47, 93; $\beta$-2: 9, 15, 17, 22, 23, $37,38,80,100,104,107,110,111,113,120,122,145,151 ; \beta-3: 49,75,76,115 ; \beta-4: 92 ; \beta-$ 5: 96,150 ) and $29 \gamma$-HPVs (species $\gamma-1: 4,65,95 ; \gamma-2: 48 ; \gamma-3: 50 ; \gamma-4: 156 ; \gamma-5: 60,88 ; \gamma-$ 6: 101, 103, 108; $\gamma-7: 109,123,134,149 ; \gamma-8: 112,119 ; \gamma-9: 116,129 ; \gamma-10: 121,130,133$; $\gamma$-11: 126; $\gamma$-12: 127, 132, 148; $\gamma$-13: 128; $\gamma$-14: 131; and HPV-SD2 [25]). HPV type species were classified according to de Villiers [3]. Two primers for the amplification of the $\beta$ globin gene were included to provide a positive control for the quality of the DNA in the 
sample [26]. Following multiplex PCR amplification, $10 \mu \mathrm{l}$ of each reaction mixture was analysed by multiplex genotyping using the Luminex technology $[20,23]$.

\section{Statistical analysis}

In total, 545 out of 558 men who were invited (97.7\%) agreed to participate (Fig. 1), including $38 \mathrm{HIV}+$ patients.

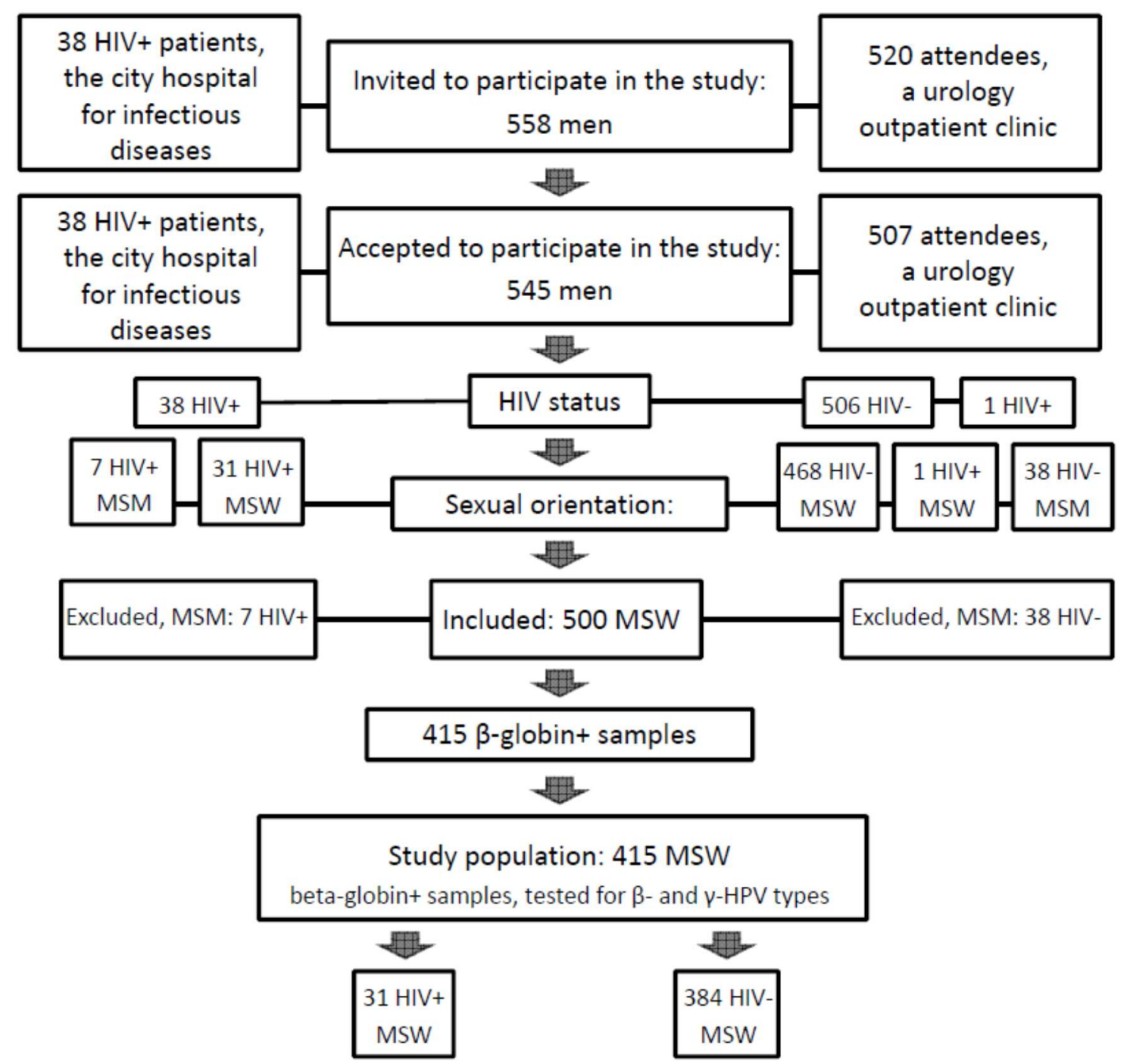

Figure 1. Flow chart of study population selection. HIV-: HIV-negative, HIV+: HIV-positive; MSW: men who have sex with women, MSM: men who have sex with men: HPV: Human papillomavirus 
According to the questionnaire given, if a man reported having had sex (anal or oral) with other men during his lifetime he was categorized as MSM. If he reported having sex with only women, he was classified as MSW. Of those enrolled, 500 men (91.7\%) reported being MSW and 45 (8.3\%) MSM. To avoid the confounding effect of MSM versus MSW, MSMs $(n=45)$ were excluded from the analyses. In addition, 85 men having $\beta$-globinnegative samples were excluded, resulting in 385 men in the present analysis; $31 \mathrm{HIV}+$ and 354 HIV-.

This analysis examined the prevalence of $\beta$ - and $\gamma$-HPV types in a population of HIV+ and HIV- MSW, as well as associations between these types and sociodemographic characteristics. The proportions of $\beta$ - and $\gamma$-HPVs were calculated overall and by HIV status. Odds Ratios (OR) and 95\% confidence intervals (CI) were calculated using logistic regression to assess associations. Specifically, separate univariate logistic regression was used to evaluate the association between $\beta$ - and $\gamma$-HPV and HIV status (positive versus negative). Univariate and multivariate logistic regression was also used to evaluate the association between $\beta$ - and $\gamma$-HPV detection (separately) and age, age at sexual debut, and number of lifetime sexual partners (categorical) among HIV-negative participants. All analyses were completed using Stata versions 11.0 and 14.0 (StataCorp, College Station, TX, USA).

\section{Results}

Among the sample of 385 MSW, the median age was 31.5 years (range 18-60), the median age at sexual debut was 17.5 years (range 9-27, 61.8\% between ages 16-19) and the median number of sexual partners was 15 (range 1-700).

The overall prevalence of $\beta$ - and $\gamma$-HPVs was $24.4 \%(n=94)$ and $13.8 \%(n=53)$, respectively (Table 1). Among the 354 HIV- MSW, anal $\beta$-HPV positivity was $20.1 \%(n=71)$ and anal $\gamma$-HPV positivity was $10.7 \%(n=38)$ (Table 1$)$. Among the $31 \mathrm{HIV}+\mathrm{MSW}, \beta-\mathrm{HPV}$ positivity was $74.2 \%(n=23)$ and $\gamma$-HPV positivity was $48.4 \%(n=15)$. Multiple $\beta$ - infections were more prevalent in HIV+ than in HIV- MSW (56.5\% vs 21.1\%) (Table 1).

Due to the lack of the sociodemographic (age) and sexual behaviour characteristics collected from HIV+ MSW, only univariate analyses are presented. $\beta$ - and $\gamma$-HPV types were significantly more likely to be detected in the anal samples of HIV+ compared to HIV-MSW, 
with an odds ratio of 11.46 (95\%CI: 4.92-26.69) and 7.80 (95\%CI: 3.57-17.02) for $\beta$ - and $\gamma$-HPV, respectively.

Table 1. Univariate and multivariate associations between HIV status and likelihood of having any $\beta$ - or $\gamma$-HPV detected in anal samples of $n=385$ MSW.

\begin{tabular}{|c|c|c|c|c|c|c|}
\hline & \multicolumn{3}{|c|}{$\beta$-HPV } & \multicolumn{3}{|c|}{$\gamma-\mathrm{HPV}$} \\
\hline & $\begin{array}{l}\text { any } \\
\beta-H P V\end{array}$ & $\begin{array}{l}>1 \\
\beta-H P V b\end{array}$ & $\begin{array}{l}\text { Unadjusted } \\
\text { OR }\end{array}$ & $\begin{array}{l}\text { any } \\
\gamma-\mathrm{HPV}\end{array}$ & $\begin{array}{l}>1 \\
\gamma-\mathrm{HPV}^{\mathrm{b}}\end{array}$ & $\begin{array}{l}\text { Unadjusted } \\
\text { OR }\end{array}$ \\
\hline $\begin{array}{l}\text { HIV status } \\
\text { (\%) } \\
\text { HIV- } \\
\text { HIV+ }\end{array}$ & $\begin{array}{l}71 / 354 \\
(20.1) \\
23 / 31 \\
(74.2)\end{array}$ & $\begin{array}{l}15 / 71 \\
(21.1) \\
13 / 23 \\
(56.5)\end{array}$ & $\begin{array}{l}\text { ref } \\
11.46 \\
(4.92-26.69)\end{array}$ & $\begin{array}{l}38 / 354 \\
(10.7) \\
15 / 31 \\
(48.4)\end{array}$ & $\begin{array}{l}8 / 38 \\
(21.1) \\
2 / 15 \\
(13.3)\end{array}$ & $\begin{array}{l}\text { ref } \\
7.80 \\
(3.57-17.02)\end{array}$ \\
\hline $\begin{array}{l}\text { Total number } \\
(\%)\end{array}$ & $\begin{array}{l}94 / 385 \\
(24.4)\end{array}$ & $\begin{array}{l}28 / 94 \\
(29.8)\end{array}$ & & $\begin{array}{l}53 / 385 \\
(13.8)\end{array}$ & $\begin{array}{l}10 / 53 \\
(18.9)\end{array}$ & \\
\hline
\end{tabular}

ancludes participants who had at least one interpretable ( $\beta$-globin positive) anal sample for any of the two HPV genus types tested ( $\beta$-HPVs, and $\gamma$-HPVs); b Among participants who tested positive for that genera of HPV; HIV-: HIV-negative; HIV+: HIV-positive .

With regard to $\beta$-HPV, 34 out of $43 \beta$-HPV types were detected among the MSW studied. The most frequently detected $\beta$-HPVs among HIV- MSW were HPV types 110 (2.0\%), 124 (2.0\%) and 22 (0.9\%). Among HIV+ MSW, HPV types 22 (25.8\%), 12 (19.4\%), 38 (19.4\%) and 5 (16.1\%) were most frequently detected (Fig. 2). On the level of species, $\beta 2$-HPV was most common among both HIV- and HIV+ MSW (Fig. 2).

A total of 19 out of $29 \gamma$-HPV types were detected. The most commonly detected $\gamma$-HPV types were 95, 132, 50 in HIV- MSW and types 148, 133, 123 and 50 in HIV+ MSW (Fig. 3). Among HIV-MSW, HPV species $\gamma$ - 1 was the most common among HIV-and $\gamma$-HPV species $10,7,6$ and 12 were most common among HIV+. $\gamma$-HPV species 4 and 13 were found only among HIV+ men.

A multivariate analysis was conducted among the 384 HIV- MSW (Table 2). 
Table 2. Univariate and multivariate associations between sociodemographic and sexual behaviour risk factors and having $\beta$-HPVs or $\gamma$-HPVs detected of anal samples of $n=354$ HIV-negative MSW

\begin{tabular}{|c|c|c|c|c|c|}
\hline \multirow{2}{*}{$\begin{array}{l}\text { Background } \\
\text { characteristic }^{\text {a,b }}\end{array}$} & \multirow{2}{*}{$\begin{array}{c}\text { Total } \\
\text { number } \\
(\%)\end{array}$} & \multicolumn{2}{|c|}{$\beta$-HPVa } & \multicolumn{2}{|c|}{$\gamma$-HPVa } \\
\hline & & Unadjusted OR & Adjusted OR & Unadjusted OR & $\begin{array}{l}\text { Adjusted } \\
\text { OR }^{c}\end{array}$ \\
\hline \multicolumn{6}{|l|}{ Age } \\
\hline $18-24$ & $\begin{array}{c}71 \\
(20.2)\end{array}$ & 1 & 1 & 1 & 1 \\
\hline $25-29$ & $\begin{array}{c}88 \\
(25.1)\end{array}$ & $\begin{array}{c}2.26 \\
(0.97-5.29)\end{array}$ & $\begin{array}{c}1.95 \\
(0.82-4.64)\end{array}$ & $\begin{array}{c}0.46 \\
(0.17-1.27)\end{array}$ & $\begin{array}{c}0.43 \\
(0.15-1.20)\end{array}$ \\
\hline $30-34$ & $\begin{array}{c}92 \\
(26.2)\end{array}$ & $\begin{array}{c}1.32 \\
(0.54-3.22)\end{array}$ & $\begin{array}{c}1.04 \\
(0.41-2.63)\end{array}$ & $\begin{array}{c}0.51 \\
(0.19-1.35)\end{array}$ & $\begin{array}{c}0.47 \\
(0.17-1.30)\end{array}$ \\
\hline $35-39$ & $\begin{array}{c}48 \\
(13.7)\end{array}$ & $\begin{array}{c}2.02 \\
(0.76-5.32)\end{array}$ & $\begin{array}{c}1.32 \\
(0.47-3.74)\end{array}$ & $\begin{array}{c}0.77 \\
(0.26-2.24)\end{array}$ & $\begin{array}{c}0.57 \\
(0.18-1.80)\end{array}$ \\
\hline $40+$ & $\begin{array}{c}52 \\
(14.8)\end{array}$ & $\begin{array}{c}2.03 \\
(0.78-5.27)\end{array}$ & $\begin{array}{c}1.32 \\
(0.48-3.62)\end{array}$ & $\begin{array}{c}0.70 \\
(0.24-2.03)\end{array}$ & $\begin{array}{c}0.57 \\
(0.18-1.80)\end{array}$ \\
\hline \multicolumn{6}{|c|}{ Age at sexual debut } \\
\hline$<16$ & $\begin{array}{c}62 \\
(17.7) \\
\end{array}$ & 1 & 1 & 1 & 1 \\
\hline $16-19$ & $\begin{array}{c}217 \\
(61.8)\end{array}$ & $\begin{array}{c}1.47 \\
(0.67-3.21)\end{array}$ & $\begin{array}{c}1.81 \\
(0.80-4.11)\end{array}$ & $\begin{array}{c}0.96 \\
(0.39-2.35)\end{array}$ & $\begin{array}{c}1.10 \\
(0.43-2.81)\end{array}$ \\
\hline $20+$ & $\begin{array}{c}72 \\
(20.5)\end{array}$ & $\begin{array}{c}1.79 \\
(0.73-4.36)\end{array}$ & $\begin{array}{c}2.69 \\
(1.00-7.25)\end{array}$ & $\begin{array}{c}0.83 \\
(0.27-2.52)\end{array}$ & $\begin{array}{c}1.04 \\
(0.31-3.54)\end{array}$ \\
\hline
\end{tabular}

Number of lifetime sexual partners

\begin{tabular}{|l|c|c|c|c|c|}
\hline $0-5$ & $\begin{array}{c}76 \\
(21.8)\end{array}$ & 1 & 1 & 1 & 1 \\
\hline $6-10$ & $\begin{array}{c}78 \\
(22.4)\end{array}$ & $\begin{array}{c}2.35 \\
(0.90-6.13)\end{array}$ & $\begin{array}{c}2.66 \\
(1.00-7.03)\end{array}$ & $\begin{array}{c}0.97 \\
(0.32-2.92)\end{array}$ & $\begin{array}{c}0.98 \\
(0.32-2.99)\end{array}$ \\
\hline $11-20$ & 73 & 4.06 & 4.54 & 1.06 & 1.10 \\
& $(20.9)$ & $(1.60-10.27)$ & $(1.74-11.87)$ & $(0.35-3.19)$ & $(0.36-3.40)$ \\
\hline$>20$ & 122 & 2.80 & 3.63 & 1.60 & 1.65 \\
$(1.15-6.80)$ & $(1.40-9.41)$ & $(0.63-4.05)$ & $(0.59-4.58)$ \\
\hline
\end{tabular}

ancludes participants who had at least one interpretable ( $\beta$-globin positive) anal sample for any of the two HPV genus types tested ( $\beta$-HPV and $\gamma$-HPV gamma); bThe following variables had missing values: age (4 missing); age at sexual debut (4 missing); number of lifetime sexual partners ( 6 missing); 'Adjusted for age, age at sexual debut, and number of lifetime sex partners.

The adjusted ORs for the association between total number of lifetime female sexual partners and $\beta$-HPV positivity varied from 2.66 (6-10 partners; 95\%CI: 1.00-7.03) to 4.54 (95\%CI: 1.74-11.87). No significant association was seen between number of lifetime sexual partners and detection of $\gamma$-HPV (Table 2). In addition, later age at sexual debut was not significantly associated with anal $\beta$-HPV or $\gamma$-HPV infection. 


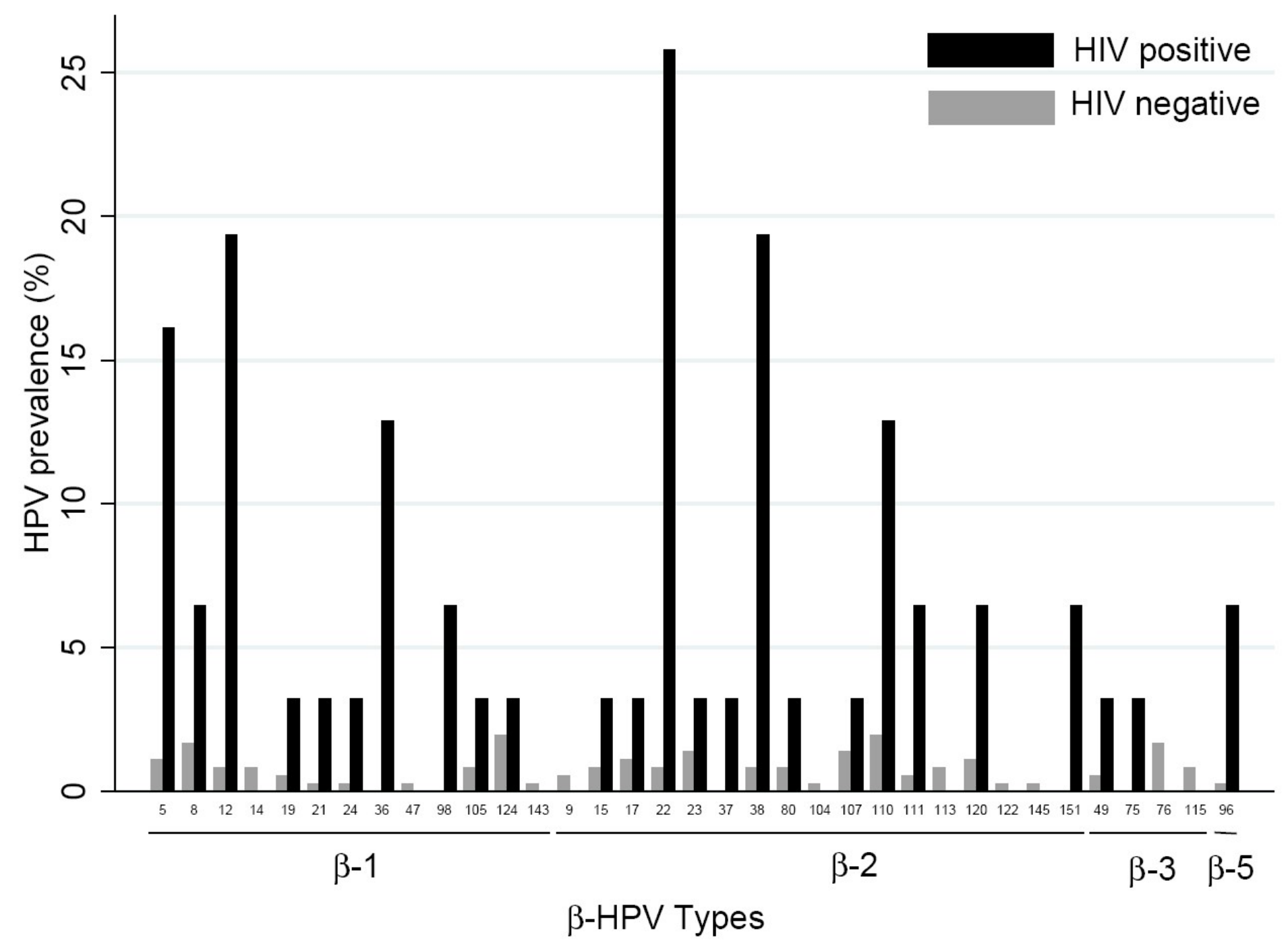

Figure 2. Genotype-specific prevalence for $\beta$ - HPVs by HIV status. HIV-: HIV-negative, HIV+: HIV-positive 


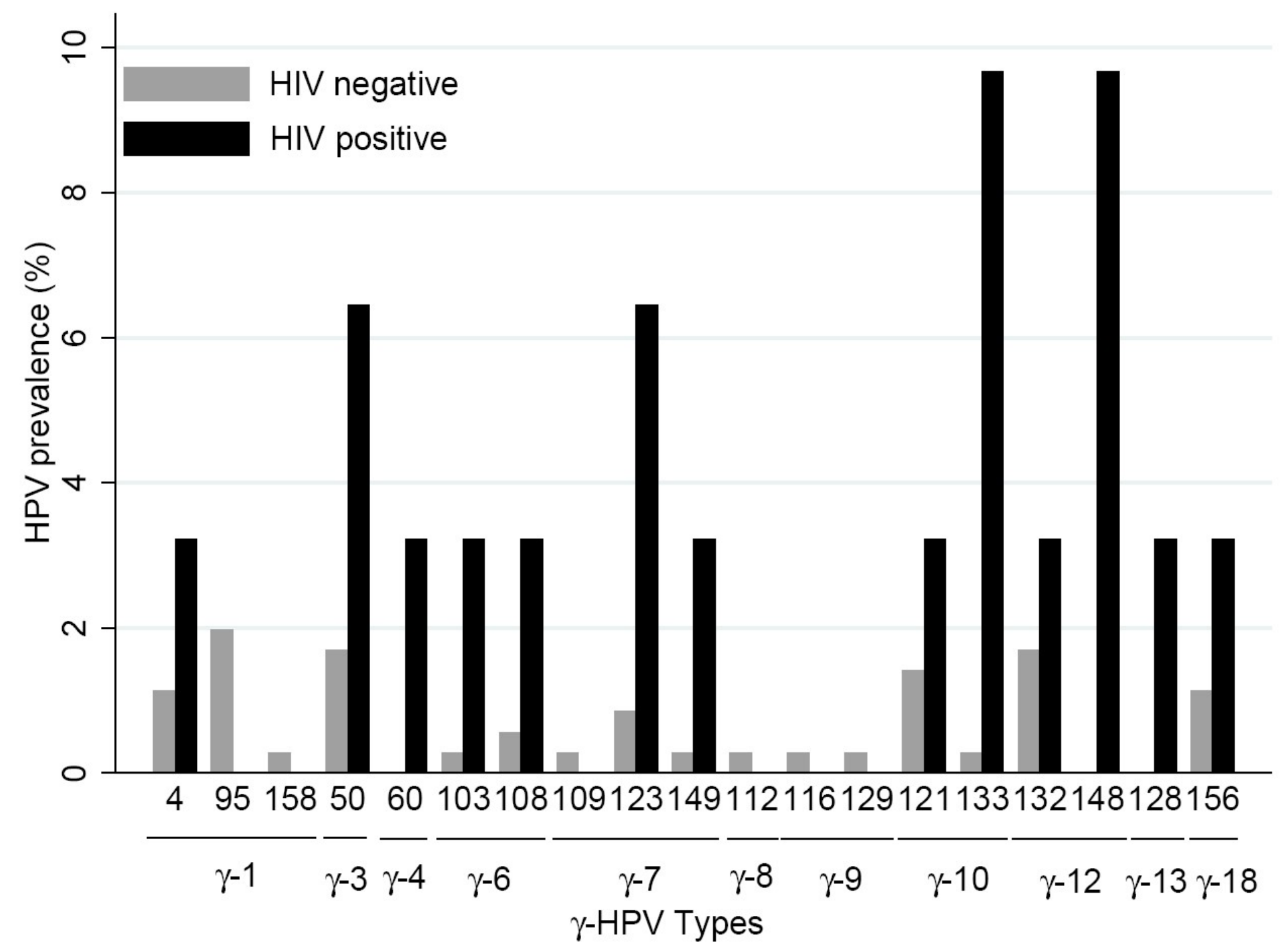

Figure 3. Genotype-specific prevalence for $\gamma$-HPVs by HIV status. HIV-: HIV-negative, HIV+: HIV-positive 
Table 3. Reported varied worldwide prevalence for $\beta$ - and $\gamma$-HPV types in the male anal canal.

\begin{tabular}{|c|c|c|c|c|c|c|c|}
\hline \multirow{2}{*}{$\begin{array}{c}\text { Study } \\
\text { country }\end{array}$} & \multirow{2}{*}{$\begin{array}{c}\text { Study } \\
\text { population }\end{array}$} & \multirow{2}{*}{$\begin{array}{c}\text { HPV genotyping, } \\
\text { technique } \\
\text { employed }\end{array}$} & \multirow{2}{*}{$\begin{array}{l}\text { Studied } \\
\text { samples }\end{array}$} & \multicolumn{2}{|c|}{$\beta$-HPV types } & \multicolumn{2}{|c|}{$\gamma$-HPV types } \\
\hline & & & & $\begin{array}{c}\text { Overall } \\
\text { prevalence }\end{array}$ & $\begin{array}{c}\text { Most } \\
\text { common }\end{array}$ & $\begin{array}{c}\text { Overall } \\
\text { prevalence }\end{array}$ & $\begin{array}{c}\text { Most } \\
\text { common }\end{array}$ \\
\hline \multirow[t]{2}{*}{ Russia, this study } & HIV- MSW & Luminex & 354 & 20.1 & $110,124,22$ & 10.7 & $95,132,50$ \\
\hline & HIV+ MSW & Luminex & 31 & 74.2 & $22,12,38$ & 48.4 & $148,133,123$ \\
\hline USA [15] & HIV-men & Luminex & 238 & 48.7 & \multirow{3}{*}{$38,21,22$} & & \\
\hline Brazil [15] & HIV-men & Luminex & 241 & 48.6 & & & \\
\hline Mexico [15] & HIV-men & Luminex & 238 & 65.6 & & & \\
\hline \multirow[t]{4}{*}{ Italy [12] } & HIV- MSM & Luminex & 602 & 27.2 & $111,120,24$ & & \\
\hline & $\mathrm{HIV}+\mathrm{MSM}$ & Luminex & 602 & 28.6 & $111,120,38$ & & \\
\hline & HIV- MSM & Luminex & 597 & & & 27.9 & $121,50,133$ \\
\hline & HIV+ MSM & Luminex & 597 & & & 33.5 & $121,108,132$ \\
\hline \multirow[t]{2}{*}{ Spain [13] } & HIV- MSM & Luminex & 153 & 59.1 & 38,120 & 57.7 & 133,121 \\
\hline & $\mathrm{HIV}+\mathrm{MSM}$ & Luminex & 66 & 65.6 & 12,107 & 68.2 & 121,50 \\
\hline \multirow[t]{2}{*}{ Slovenia [11] } & HIV- MSM & HPV Linear Array & 112 & 58.9 & \multirow{2}{*}{$36,38,23,24$} & & \\
\hline & $\mathrm{HIV}+\mathrm{MSM}$ & HPV Linear Array & 23 & 95.7 & & & \\
\hline
\end{tabular}

HIV-: HIV-negative; HIV+: HIV-positive 


\section{Discussion}

We found cutaneous $\beta$ - and $\gamma$-HPV types to be relatively common in the anal canal of Russian MSW men (24\% and 14\%, respectively). Our findings follow those from a pair of publications on HPV prevalence in the HIM study across three countries in the Western hemisphere, Mexico, Brazil and the USA, reported $\beta$-HPV prevalences of $65.6 \%, 48.6 \%$, and $48.7 \%$, respectively [15] Findings of $66 \%$ and $27 \% \beta$-HPV prevalence in Spain and Italy have also been reported $[12,13]$. The current study is the largest known cohort of MSW from the Eastern hemisphere tested for a broad range of $\beta$ - and $\gamma$ - HPV types using technology similar to the aforementioned studies (Luminex). Taken together, these findings suggest a large variation in cutaneous HPV prevalence worldwide.

A low number of MSM enrolled in this study, and were therefore excluded from the main analyses. Discrimination against MSM populations in the country is a possibility, thus limiting their inclusion in large research efforts at present $[27,28]$. However, data from other studies shows that HPVs were detected more often in MSM than MSW [11,29]. These findings suggest that penile-anal sexual activity might indeed result in acquiring cutaneous HPV infections in some individuals, but the relatively common detection of these types in MSW does not allow this theory to entirely describe transmission.

Several hypotheses might explain transmission of cutaneous HPV types to the anal canal among MSW. Cutaneous HPV virions may be transmitted to the anal canal from other parts of the body that harbour active infections, as the presence of HPV DNA does not necessarily indicate the presence of infectious virus [30]. Indeed, cutaneous HPV is commensal by nature, and commonly detected in many regions of the body, including but not limited to the oral cavity [31] and gargles [32], nostril [32] and oesophageal [33] mucosa. Supportive of a role for non-sexual transmission routes, neither the HIM study $[14,15]$ nor our results found any strong associations between sexual activity and HPV detection. Another hypothesis is that HPV transmission could occur via sexual transmission but through routes apart from penile-anal, such as finger-genital transmission via self- or partnerinitiated inoculation $[15,34,35]$. Unfortunately, men in our study were not asked to provide details concerning routine sexual practices that could involve anal touching (frequency of anal touching, use of sex toys, etc.). Future studies among MSM and MSW evaluating both non-sexual and sexual transmission routes including self-inoculation could be helpful in further establishing probable transmission routes. 
Other limitations of our study do exist. For one, it is possible that men did not fully disclose sexual relations with other men, which could have effectively led to misclassification of MSM versus MSW. However, it is unlikely that this accounts for all MSW participants in whom HPV was detected. Further, due to the transient nature of HPV infection, it is likely that current infection status is due to recent sexual activity than lifetime sexual history. Therefore, it is possible among our study population that MSW versus MSM classification based on lifetime report of having ever had sex with another man was not entirely representative of recent sexual activity, leading to a potential loss of information among men who were MSM but whose recent behaviour was more similar to MSW activities, for example. Also, we were not able to collect data on key sociodemographic and sexual risk factors for HIV+ subjects, and were therefore limited in our ability to make any interpretations of adjusted risk among this population. Finally, the commensal nature of cutaneous HPV makes it inherently much more difficult to establish associations between its prevalence and important determinants compared to $\alpha$-HPVs. Thus, we can only continue to accumulate evidence to build on this topic to move beyond this limitation.

Evidence regarding the relationship between anal cutaneous HPVs and HIV status is still building. In one prospective study, HIV+ status was significantly associated with a higher prevalence of anal $\beta$-HPV infection among the 135 Slovenian MSM [11]. In contrast, a study of 609 Italian MSM showed no significant association between $\beta$ - and $\gamma$-HPV infection and HIV status, socio-demographic or sexual behavioral factors [12]. However, enrolled HIV+ were older than HIV- MSM and most of them were receiving combined antiretroviral therapy at the time of sampling [12]. In the current study, anal prevalence $\beta$ - and $\gamma$-HPV detection was significantly higher in HIV+ than in HIV- men, although the low sample size of HIV+ is recognized as a limitation. Future studies with larger sample sizes may be able to strengthen the evidence base of the relationship between HIV and cutaneous HPV.

The current study provides additional evidence that cutaneous HPVs are a relatively common finding in the anal canal of MSW, favouring the hypothesis that transmission routes other than penile-anal exist for these types of HPV. Preliminary comparison with other recent findings indicates that it is possible that their prevalence in men worldwide could vary (Table 3). However, it must be acknowledged that direct comparisons between this and other studies should be regarded with caution as the laboratory techniques used 
may differ across studies as may do the choice of underlying population with regard to $\alpha$ HPV infection status.

Nevertheless, we believe that understanding the difference in prevalence across populations is the first step to understanding the etiology of cutaneous HPV infection. Understanding determinants of infection and high-risk groups is also potentially important information as we continue to refine our knowledge of the role of cutaneous HPVs in shared and distinct pathways for cancer pathogenesis [36], in particular through activation of DNA damage and TLR9 signalling pathways. Interestingly, $\beta$-HPV type 38 was recently discovered to the property of repressing the TLR9 signalling pathway in common with oncogenic viruses [8].

In summary, our findings indicate that $\beta$ - and $\gamma$-HPV types may be relatively common in the anal canal of MSW men. Therefore, knowledge regarding $\beta$ - and $\gamma$-HPV types and their distribution in diverse male populations is essential for developing a better understanding of the natural history, transmission dynamics, and the potential role of different HPV types as co-factors in the development of anogenital malignancies.

\section{Funding and conflict of interests}

The work reported in this paper was undertaken during the tenure of a Postdoctoral Fellowship from the International Agency for Research on Cancer, partially supported by the European Commission FP7 Marie Curie Actions - People - Co-funding of regional, national and international programmes (COFUND). Introduction to STI outpatient clinic work with specific attention for interviewing and sampling high-risk populations in Amsterdam, the Netherlands was supported through the UNESCO-American Society for Microbiology (Travel Award 2006 to V. Smelov). This work was supported in part by the Swedish Cancer Society (Scholarship 2011 to Vitaly Smelov). The funders had no role in study design, data collection and analysis.

\section{Ethical approval}

Ethical Committee of the Department of Clinical Investigations and Intellectual Property of St. Petersburg Medical Academy of Postgraduate Studies (North-Western State Medical University named after I.I. Mechnikov since 2011) under the Federal Agency of Public 
Health and Social Development of Roszdrav (Extract from Minutes No. 10 of SPbMAPS Ethical Committee meeting; date of approval: 10 November 2010).

\section{Acknowledgments}

The authors are grateful to the personnel of the Laboratory of Microbiology at the D.O. Ott Research Institute of Obstetrics and Gynecology, St. Petersburg State University Outpatient clinic and St. Petersburg City Infectious Diseases Hospital (all are in St. Petersburg, Russia), Laboratory of Immunogenetics at the VU University Medical Center (Amsterdam, the Netherlands) and the Department of Laboratory Medicine at the Karolinska Institutet (Stockholm, Sweden) for their dedicated technical and administrative support. The authors are grateful to Dr. Catherine Sauvaget (Screening Group, WHO/IARC, Lyon, France) for careful reading and comments. The authors are deeply grateful to Dr. Servaas Morré and Mrs. Jolijne Plejster (VU University Medical Center, Amsterdam) for the proper storing the samples and Prof. Joakim Dillner (Karolinska Institutet, Stockholm) for the support and organizing their shipments between the institutions.

\section{References}

[1] D. Bzhalava, P. Guan, S. Franceschi, J. Dillner, G. Clifford, A systematic review of the prevalence of mucosal and cutaneous human papillomavirus types, Virology 445 (2013) 224-231.

[2] Reference clones at International HPV Reference Center, (n.d.).

http://www.hpvcenter.se/html/refclones. html?\%3C?php\%20echo\%20time0;\%20? \%3E (accessed June 4, 2015).

[3] E.-M. de Villiers, Cross-roads in the classification of papillomaviruses, Virology 445 (2013) 2-10.

[4] International Agency for Research on Cancer. Monographs on the evaluation of carcinogenic risks to humans, volume 100 B, biological agents. Lyon: IARC, 2012.
[5] C.M. Proby, C.A. Harwood, R.E. Neale, A.C. Green, S. Euvrard, L. Naldi, G. Tessari, M.C.W. Feltkamp, M.N.C. de Koning, W.G.V. Quint, T. Waterboer, M. Pawlita, S. Weissenborn, U. Wieland, H. Pfister, E. Stockfleth, I. Nindl, D. Abeni, J.T. Schegget, J.N. Bouwes Bavinck, EPI-HPV-UV-CA group, A case-control study of betapapillomavirus infection and cutaneous squamous cell carcinoma in organ transplant recipients, Am. J. Transplant 11 (2011) 1498-1508.

[6] R.E. Neale, S. Weissenborn, D. Abeni, J.N.B. Bavinck, S. Euvrard, M.C.W. Feltkamp, A.C. Green, C. Harwood, M. de Koning, L. Naldi, I. Nindl, M. Pawlita, C. Proby, W.G. Quint, T. Waterboer, U. Wieland, H. Pfister, Human 
papillomavirus load in eyebrow hair

follicles and risk of cutaneous squamous cell carcinoma, Cancer Epidemiol Biomark Prev 22 (2013) 719-727.

[7] L. Struijk, J.N. Bouwes Bavinck, P. Wanningen, E. van der Meijden, R.G.J. Westendorp, J. Ter Schegget, M.C.W. Feltkamp, Presence of human papillomavirus DNA in plucked eyebrow hairs is associated with a history of cutaneous squamous cell carcinoma, $J$ Invest Dermatol 121 (2003) 1531-1535.

[8] L. Pacini, C. Savini, R. Ghittoni, D. Saidj, J. Lamartine, U.A. Hasan, R. Accardi, M. Tommasino, Downregulation of Toll-Like Receptor 9 Expression by Beta Human Papillomavirus 38 and Implications for Cell Cycle Control, J Virol 89 (2015) 11396-11405.

[9] T. Waterboer, D. Abeni, F. Sampogna, A. Rother, C. Masini, P. Sehr, K.M. Michael, M. Pawlita, Serological association of beta and gamma human papillomaviruses with squamous cell carcinoma of the skin, $\mathrm{BrJ}$ Dermatol 159 (2008) 457-459.

[10] A. Paradisi, T. Waterboer, F. Sampogna, S. Tabolli, S. Simoni, M. Pawlita, D. Abeni, Seropositivity for human papillomavirus and incidence of subsequent squamous cell and basal cell carcinomas of the skin in patients with a previous nonmelanoma skin cancer, Br J Dermatol 165 (2011) $782-791$.

[11] B. Mlakar, B.J. Kocjan, L. Hošnjak, K. Fujs Komloš, M. Milošević, M. Poljak, Betapapillomaviruses in the anal canal of HIV positive and HIV negative men who have sex with men, J Clin Virol 61 (2014) 237-241.
[12] M.G. Donà, T. Gheit, A. Latini, M. Benevolo, M. Torres, V. Smelov, S. McKay-Chopin, A. Giglio, A. Cristaudo, M. Zaccarelli, M. Tommasino, M. Giuliani, Alpha, beta and gamma Human Papillomaviruses in the anal canal of HIV-infected and uninfected men who have sex with men, J Infect 71 (2015) 74-84.

[13] M. Torres, T. Gheit, S. McKay-Chopin, C. Rodríguez, J.D. Romero, R. Filotico, M.G. Doná, M. Ortiz, M. Tommasino, Prevalence of beta and gamma human papillomaviruses in the anal canal of men who have sex with men is influenced by HIV status, J Clin Virol 67 (2015) 47-51.

[14] L. Sichero, A.G. Nyitray, E.M. Nunes, B. Nepal, S. Ferreira, J.S. Sobrinho, M.L. Baggio, L. Galan, R.C. Silva, E. LazcanoPonce, A.R. Giuliano, L.L. Villa, the HIM Study Group, Diversity of human papillomavirus in the anal canal of men: the HIM Study, Clin Microbiol Infect (2015).

[15] E.M. Nunes, S.L. Sudenga, T. Gheit, M. Tommasino, M.L. Baggio, S. Ferreira, L. Galan, R.C. Silva, C.M. Pierce Campbell, E. Lazcano-Ponce, A.R. Giuliano, L.L. Villa, L. Sichero, HIM Study group, Diversity of beta-papillomavirus at anogenital and oral anatomic sites of men: The HIM Study, Virology 495 (2016) 33-41.

[16] S.M. Tugizov, R. Herrera, P. Chin-Hong, P. Veluppillai, D. Greenspan, J. Michael Berry, C.D. Pilcher, C.H. Shiboski, N. Jay, M. Rubin, A. Chein, J.M. Palefsky, HIV-associated disruption of mucosal epithelium facilitates paracellular penetration by human papillomavirus, Virology 446 (2013) 378-388.

[17] Smelov, Vitaly, Catsburg, Arnold, Shipitsyna, Elena, de Vries, Henry J.C., 
Shalepo, Kira, Gorelov, Andrey, Pleijster, Joelin, Savelkoul, Paul H.M., Peña, A.

Salvador, Savitcheva, Alevtina, Morré, Servaas A., Chlamydia trachomatis infections in St. Petersburg, Russia: Preliminary serogroup distribution results in men., in: Chlamydial Infect. Proc. Elev. Int. Symp. Hum. Chlamydial Infect., ed. / M. Chernesky; H. Caldwell; G. Christiansen. San Francisco, CA, Niagara-on-the-Lake, Ontario, Canada, 2006.

[18] V. Smelov, C. Eklund, D. Bzhalava, A. Novikov, J. Dillner, Expressed prostate secretions in the study of human papillomavirus epidemiology in the male, PloS One 8 (2013) e66630.

[19] O. Forslund, A. Antonsson, K. Edlund, A.J.C. van den Brule, B.-G. Hansson, C.J.L.M. Meijer, W. Ryd, E. Rylander, A. Strand, G. Wadell, J. Dillner, B. Johansson, Populationbased type-specific prevalence of high-risk human papillomavirus infection in middleaged Swedish women, J Med Virol 66 (2002) 535-541.

[20] M. Schmitt, I.G. Bravo, P.J.F. Snijders, L. Gissmann, M. Pawlita, T. Waterboer, Beadbased multiplex genotyping of human papillomaviruses, J Clin Microbiol 44 (2006) 504-512.

[21] T. Gheit, G. Billoud, M.N.C. de Koning, F. Gemignani, O. Forslund, B.S. Sylla, S. Vaccarella, S. Franceschi, S. Landi, W.G.V. Quint, F. Canzian, M. Tommasino, Development of a sensitive and specific multiplex PCR method combined with DNA microarray primer extension to detect Betapapillomavirus types, J Clin Microbiol 45 (2007) 2537-2544.

[22] J.B. Ruer, L. Pépin, T. Gheit, C. Vidal, B. Kantelip, M. Tommasino, J.L. Prétet, C.
Mougin, F. Aubin, Detection of alpha- and beta-human papillomavirus (HPV) in cutaneous melanoma: a matched and controlled study using specific multiplex PCR combined with DNA microarray primer extension, Exp Dermatol 18 (2009) 857-862.

[23] M. Schmitt, B. Dondog, T. Waterboer, M. Pawlita, M. Tommasino, T. Gheit, Abundance of multiple high-risk human papillomavirus (HPV) infections found in cervical cells analyzed by use of an ultrasensitive HPV genotyping assay, J Clin Microbiol 48 (2010) 143-149.

[24] S.S. Hampras, A.R. Giuliano, H.-Y. Lin, K.J. Fisher, M.E. Abrahamsen, B.A. Sirak, M.R. Iannacone, T. Gheit, M. Tommasino, D.E. Rollison, Natural history of cutaneous human papillomavirus (HPV) infection in men: the HIM study, PloS One 9 (2014) e104843.

[25] J.L. Mokili, B.E. Dutilh, Y.W. Lim, B.S. Schneider, T. Taylor, M.R. Haynes, D. Metzgar, C.A. Myers, P.J. Blair, B. Nosrat, N.D. Wolfe, F. Rohwer, Identification of a novel human papillomavirus by metagenomic analysis of samples from patients with febrile respiratory illness, PloS One 8 (2013) e58404.

[26] R.K. Saiki, D.H. Gelfand, S. Stoffel, S.J. Scharf, R. Higuchi, G.T. Horn, K.B. Mullis, H.A. Erlich, Primer-directed enzymatic amplification of DNA with a thermostable DNA polymerase, Science 239 (1988) 487491.

[27] Men having sex with men in Eastern Europe: Implications of a hidden HIV epidemic. Regional analysis report., (2010). http://www.aidstar- 
two.org/upload/MSM-Regional-

Report_Final_November-2-2010.pdf.

[28] A.L. Wirtz, C.E. Zelaya, A. Peryshkina, C. Latkin, V. Mogilnyi, N. Galai, K. Dyakonov, C. Beyrer, Social and structural risks for HIV among migrant and immigrant men who have sex with men in Moscow, Russia: implications for prevention, AIDS Care 26 (2014) 387-395.

[29] A.G. Nyitray, R.J. Carvalho da Silva, M.L. Baggio, D. 'elle Smith, M. Abrahamsen, M. Papenfuss, H.-Y. Lin, M. Quiterio, J. Salmerón, E. Lazcano-Ponce, L.L. Villa, A.R. Giuliano, Six-month incidence, persistence, and factors associated with persistence of anal human papillomavirus in men: the HPV in men study, J Infect Dis 204 (2011) 1711-1722.

[30] V.Smelov, C. Eklund, L.S. Arroyo Mühr, E. Hultin, J. Dillner, Are human papillomavirus DNA prevalences providing high-flying estimates of infection? An international survey of HPV detection on environmental surfaces, Sex Transm Infect 89 (2013) 627.

[31] D. Bottalico, Z. Chen, A. Dunne, J. Ostoloza, S. McKinney, C. Sun, N.F. Schlecht, M. Fatahzadeh, R. Herrero, M. Schiffman, R.D. Burk, The oral cavity contains abundant known and novel human papillomaviruses from the Betapapillomavirus and Gammapapillomavirus genera, J Infect Dis 204 (2011) 787-792.

[32] O. Forslund, H. Johansson, K.G. Madsen, K. Kofoed, The nasal mucosa contains a large spectrum of human papillomavirus types from the Betapapillomavirus and Gammapapillomavirus genera, J Infect Dis 208 (2013) 1335-1341.
[33] M.L. Tornesello, R. Monaco, O. Nappi, L. Buonaguro, F.M. Buonaguro, Detection of mucosal and cutaneous human papillomaviruses in oesophagitis, squamous cell carcinoma and adenocarcinoma of the oesophagus, J Clin Virol 45 (2009) 28-33.

[34] C. Sonnex, S. Strauss, J.J. Gray, Detection of human papillomavirus DNA on the fingers of patients with genital warts, Sex Transm.Infect 75 (1999) 317-319.

[35] B.Y. Hernandez, L.R. Wilkens, X. Zhu, P. Thompson, K. McDuffie, Y.B. Shvetsov, L.E. Kamemoto, J. Killeen, L. Ning, M.T. Goodman, Transmission of human papillomavirus in heterosexual couples, Emerg Infect Dis 14 (2008) 888-894.

[36] D.A. Galloway, L.A. Laimins, Human papillomaviruses: shared and distinct pathways for pathogenesis, Curr Opin Virol 14 (2015) 87-92. 


\section{Chapter 8}

Determinants of presence of

human papillomaviruses in the anal canal of men 


\title{
Determinants of presence of human papillomaviruses \\ in the anal canal of Russian men
}

\author{
Vitaly Smelov1,2,4*, \\ K. Miriam Elfström³, \\ Carina Eklund ${ }^{2}$ \\ Olga Sokolova ${ }^{5,6}$, \\ Joakim Dillner ${ }^{2,3}$
}

Submitted

1Prevention and Implementation Group, International Agency for Research on Cancer, World Health Organization, Lyon, France; ${ }^{2}$ Department of Laboratory Medicine, Karolinska Institutet, Stockholm, Sweden; ${ }^{3}$ Department of Medical Epidemiology and Biostatistics, Karolinska Institutet, Stockholm, Sweden; ${ }^{4}$ Department of Urology, North-Western State Medical University named after I.I. Mechnikov, St. Petersburg, Russia; ${ }^{5}$ Faculty of Medicine, St. Petersburg State University, St. Petersburg, Russia; ${ }^{6}$ S. P. Botkin Memorial Clinical Hospital of Infectious Diseases, St. Petersburg, Russia. 


\begin{abstract}
Knowledge of determinants of anal HPV infections among men is still limited as most of the studies are focused on high-risk populations and geographically narrowed. Such knowledge obtained in different populations is essential for better understanding of HPV natural history, transmission dynamics, and its role in the development and prevention of anogenital malignancies in different regions. Anal canal swab samples from 359 Russian heterosexual (323 HIV-negative and 27 HIV-positive, aged 18-67 years) and 31 homosexual (26 HIV- and 5 HIV+) men attending an STI clinic were tested for 36 HPV types using a proficient Luminex assay. Anal HPV positivity was more common among MSM (p<0.0001) and among HIV-positive men ( $p=0.0002)$ but was not associated with the number of lifetime sexual partners $(\mathrm{p}=0.1470)$, age of participants $(\mathrm{p}=0.6374)$ or age at sexual debut $(\mathrm{p}=0.1470)$. HPV-positivity in anal samples was common for HIV-negative heterosexual men for overall HPV (15.7\%, n=52), oncogenic HPV (9.6\%, n=32), non-oncogenic HPV $(8.1 \%, n=27)$ and multiple HPV infections (4.5\%, n=14). The most common anal HPV types were HPV16 (5.7\%), HPV45, HPV51, HPV66, and HPV87 (1.8\% each). Although sexual orientation and HIV status are major determinants of anal presence of HPV in men, anal HPV can be frequently detected in Russian HIV-negative heterosexual men.
\end{abstract}




\section{Introduction}

WHO/International Agency for Research on Cancer has classified Human Papillomavirus (HPV) as a causal agent for anogenital cancers. Annually, there are globally 12.7 million new cancers, out of which 610,000 cases are attributable to HPV infection and 24,000 cases are anal ${ }^{1}$. In the United States, the HPV-associated anal cancer incidence rate in men has increased from $0.5 / 100,000$ in 1974 to $1.6 / 100,000$ in 2009 , representing $14.4 \%$ of the overall number of new HPV-associated cancers ${ }^{2}$.

HPV infection is the most common viral sexually transmitted infection (STI) worldwide. Men infected with human immunodeficiency virus (HIV) who have sex with men (MSM) are at increased risk of HPV infection and anal cancer ${ }^{3}$ and are in the focus of the research on anal HPV epidemiology. Only limited range of studies, most from the Americas (Brazil, Mexico, United States and Puerto-Rico) ${ }^{4-10}$ and one from Asia (Korea) ${ }^{11}$, have reported on the detection of the HPV in the anal canal of HIV-negative men practicing sex with women (MSW).

However, although 210 different HPV types have currently been established ${ }^{12}$, most studies of anal HPV epidemiology have tested for a more limited number of HPV types. Efficient genotyping can be achieved using bead-based multiplex genotyping of PCR amplimers obtained following general primer PCR 13,14.

More than $80 \%$ of anal cancer is caused by HPV ${ }^{15}$. A broader investigation of HPV infection in the anal canal of men in different populations is essential for better understanding of HPV natural history, transmission dynamics, and its role in the development of anogenital malignancies in different regions. Anal canal samples from a group of Russian men attending STI clinics were tested for presence and analysed for the determinants of presence of a large number of HPV types.

\section{Methods}

\section{Study design}

A consecutive series of men visiting the urology units of two university outpatient clinics in St. Petersburg, Russia for testing for STIs ${ }^{16}$ and a group of HIV-positive patients participating in a study on detection of lymphogranuloma venereum (LGV) infection (unpublished) were 
enrolled in the study. Men were eligible for the study if they were at least 18 years old and reported no anorectal disorders at the time of recruitment.

Participants completed a questionnaire concerning lifestyle and sexual behaviour, such as age at sexual debut, number of lifetime sex partners, sexual preferences (i.e., practicing samegender oral or anal sex), and STI history. The study clinician obtained a detailed medical history and performed a standard physical examination.

All urology clinic visitors provided blood samples for HIV and Treponema pallidum testing. In men over 40 years, prostate-specific antigen (PSA) testing was also performed ${ }^{16}$. The 31 HIV-positive patients from the infectious disease hospital were all on HAART. In addition, one patient recruited from the urology clinic was diagnosed as HIV-positive during his visit and routine blood test and was referred to the infectious disease officer, following the local regulations.

All men self-reported their sexual preferences. The questionnaire was administered during a face-to-face interview, before anal sampling. Importantly for the local context, the responses were coded.

\section{Procedure}

All men were tested for STIs following established protocols for collecting and testing urethral samples. Briefly, the men were instructed to abstain from any form of sexual contact for 3-5 days and from urination for 3-4 hours before sampling the distal urethra.

First, the study clinician sampled the urethra with a urethral swab for detection of $C$. trachomatis, $N$. gonorrhoeae, T. vaginalis, and herpes simplex virus types 1 and 2 at the local laboratory in St. Petersburg. A confirmation of the results on Chlamydia infection was completed in Amsterdam 16.

A different urethral swab wetted with phosphate buffered saline was used to sample the anal canal. The swab was inserted into the anal canal 2 centimetres deep from the anal verge and rotated $180^{\circ}$ to the right and $180^{\circ}$ to the left. Then, the swab was rinsed in a tube with 1 $\mathrm{ml}$ of phosphate buffered saline that was immediately placed in a refrigerator at $4^{\circ} \mathrm{C}$. At the end of the day the samples were transferred to a $-20^{\circ} \mathrm{C}$ freezer and stored until testing. 


\section{Detection and typing of HPV}

The HPV testing was conducted using the reference method of the HPV LabNet Global Reference Laboratory ${ }^{17}$. The modified general primer (MGP) system is a modification of the classical HPV general primer system GP5+/6+ intended to have a more uniform analytical sensitivity for different HPV types ${ }^{14}$.

In detail, HPV testing of the anal canal specimens was conducted using PCR amplification of a fragment in the L1 gene. DNA was released using a freeze-thaw-boil procedure. The quality of the sample DNA for amplification was evaluated using a beta-globin real-time PCR. Samples testing beta-globin-negative were treated with SDS/Proteinase $\mathrm{K}$ and the real-time PCR repeated. Samples that were still beta-globin-negative were not included in the present study. Samples were tested for the presence of HPV by amplifying $5 \mu$ of DNA with the MGP L1 primer system. HPV detection and genotyping were conducted on the Bioplex 200 Luminex system (Bio-Rad, Hercules, CA, USA) using multiplex bead-based hybridization with Luminex technology. Probes for 13 oncogenic (high-risk, HR-HPV) types (16, 18, 31, 33, 35 39, 45, 51, $52,56,58,59,68 \mathrm{a}$ and $68 \mathrm{~b}$, including probes for variant sequences of HPV18, 35, 51 and 58) and 23 non-oncogenic types $(6,11,26,30,40,42,43,53,54,61,66,67,70,73,74,81,82,83$, 86, 87, 89, 90 and 91) were used. Eleven negative controls $\left(\mathrm{H}_{2} \mathrm{O}\right)$ and 8 positive controls (HPV plasmid pools) were run on each PCR and Luminex plate. All samples producing an HPV positive result were re-tested.

\section{Statistical analysis}

In total, 539 out of 550 invited men (98\%) (all 38 HIV+ patients from the city hospital for infectious diseases and 501 attendees of the urology outpatient clinics) consented to the study. All enrolled men completed the survey and provided an anal canal sample for HPV testing and genotyping. In addition to $38 \mathrm{HIV}$-positive patients from the infectious disease hospital, HIV was detected in one out of 501 (0.2\%) visitors of the urology clinic, which resulted in a total of $39 \mathrm{HIV}$-positive (10.0\%) men. Beta-globin was detected in 395 (73.3\%) samples. Five men were enrolled more than once and then the first sample was retained in the study. Thus, 390 men with corresponding samples were included. If a man reported having 
had sex (anal or oral) with other men during his lifetime, he was categorized as a MSM. If sex with only women was reported, a man was classified as MSW.

Prevalent infection with $C$. trachomatis was determined from the urethral samples. HPV prevalence was calculated for individual types as well as for any HPV infection, any high-risk (HR), any non-HR, and single or multiple ( $\geq 2$ types) HPV infections. Chi-square tests of proportion were used to assess differences of proportion of any HPV infection by background characteristics. Odds Ratios (OR) and 95\% confidence intervals (CI) were calculated using logistic regression to assess bivariate and multivariate (adjusted) associations between background characteristics and the outcome of any HPV infection. The alpha level was set at 0.05 for all analyses. All analyses were completed using SAS 9.4 (Cary, NC, USA).

\section{Research ethics}

All participants provided written informed consent for this study. The institutional review board approved the study, namely the Department of Clinical Investigations and Intellectual Property, of St. Petersburg Medical Academy of Postgraduate Studies (North-Western State Medical University named after I.I. Mechnikov since 2011) under the Federal Agency of Public Health and Social Development of Roszdrav.

\section{Results}

In the present study 359 men (92.1\%) were MSW and 31 (8.0\%) MSM. The majority of the studied men were HIV-negative MSWs: 332 (85.1\%), followed by 27 HIV+ MSW (6.9\%), 26 HIV-negative MSM (6.7\%) and 5 HIV+ MSM (1.3\%) of Russian origin. The median age was 31 years (range 18-58), the median age at the time of sexual debut was 17 years (range 9-27, the majority between ages 16-19) and the median number of sexual partners was 15 (range 11000). The background characteristics are presented in Table 1. Thus, at the time of enrolment, the majority of men (92.1\%) reported being heterosexual and were tested as HIVnegative (91.8\%). 
Table 1. Distribution of background characteristics of study population.

\begin{tabular}{|c|c|c|}
\hline Background characteristic & $\begin{array}{l}\text { Total } \\
\text { n (\%) }\end{array}$ & $\begin{array}{c}\text { HIV neg/MSW } \\
\text { n (\%) }\end{array}$ \\
\hline \multicolumn{3}{|l|}{ Age $(n=43$ missing) } \\
\hline $18-24$ & $71(20.5)$ & $68(20.6)$ \\
\hline $25-29$ & $80(23.1)$ & $77(23.3)$ \\
\hline $30-34$ & $85(24.5)$ & $82(24.9)$ \\
\hline $35-39$ & $50(14.4)$ & 47 (14.2) \\
\hline $40+$ & $61(17.6)$ & $56(17.0)$ \\
\hline \multicolumn{3}{|l|}{ Reported sexual orientation } \\
\hline MSW & $359(92.1)$ & \\
\hline MSM & $31(8.0)$ & \\
\hline \multicolumn{3}{|c|}{ Age at sexual debut ( $\mathrm{n}=48$ missing) } \\
\hline$<16$ & 64 (18.7) & $59(17.9)$ \\
\hline $16-19$ & $207(60.5)$ & $202(61.2)$ \\
\hline $20+$ & $71(20.8)$ & $69(20.9)$ \\
\hline \multicolumn{3}{|c|}{ Number of lifetime sexual partners ( $\mathrm{n}=50$ missing) } \\
\hline $0-5$ & $68(20.0)$ & $68(20.7)$ \\
\hline 6-10 & $78(22.9)$ & $77(23.5)$ \\
\hline $11-20$ & $66(19.4)$ & $63(19.2)$ \\
\hline$>20$ & $128(37.7)$ & $120(36.6)$ \\
\hline \multicolumn{3}{|c|}{ Prevalent urethral chlamydia infection } \\
\hline No & $369(94.6)$ & $311(93.7)$ \\
\hline Yes & $21(5.4)$ & $21(6.3)$ \\
\hline \multicolumn{3}{|c|}{ Reported history of chlamydia infection } \\
\hline No & $238(69.8)$ & $230(70.1)$ \\
\hline Yes & $103(30.2)$ & $98(29.9)$ \\
\hline \multicolumn{3}{|l|}{ HIV status } \\
\hline HIV negative & $358(91.8)$ & \\
\hline HIV positive & $32(8.2)$ & \\
\hline
\end{tabular}


Table 2. Distribution of HPV types for the whole study population and stratified by sexual orientation and HIV status.

\begin{tabular}{|c|c|c|c|c|c|}
\hline \multirow[b]{2}{*}{ HPV types } & \multirow[b]{2}{*}{$\begin{array}{l}\text { Total, } \\
\text { n (\%) }\end{array}$} & \multicolumn{2}{|c|}{ MSW } & \multicolumn{2}{|c|}{ MSM } \\
\hline & & $\begin{array}{l}\text { HIV neg } \\
\text { n (\%) }\end{array}$ & $\begin{array}{c}\text { HIV pos } \\
\text { n (\%) }\end{array}$ & $\begin{array}{c}\text { HIV neg } \\
\text { n (\%) }\end{array}$ & $\begin{array}{c}\text { HIV pos } \\
\text { n (\%) }\end{array}$ \\
\hline \multicolumn{6}{|l|}{ Summary } \\
\hline No HPV infection detected & $308(79.0)$ & $280(84.3)$ & $16(59.3)$ & $11(42.3)$ & $1(20.0)$ \\
\hline $\begin{array}{l}\text { Any HPV type } \\
\text { (HR and/or Non-HR) }\end{array}$ & $82(21.0)$ & $52(15.7)$ & $11(40.7)$ & $15(57.7)$ & $4(80.0)$ \\
\hline Any HR HPV type (13 types) & $49(12.6)$ & $32(9.6)$ & $5(18.5)$ & $8(30.8)$ & $4(80.0)$ \\
\hline Any Non-HR HPV type & $43(11.0)$ & $27(8.1)$ & $6(22.2)$ & $9(34.6)$ & $1(20.0)$ \\
\hline Single HPV infection & $62(15.9)$ & $38(11.5)$ & $9(33.3)$ & $12(46.2)$ & $3(60.0)$ \\
\hline Multiple HPV infection & $20(5.1)$ & $14(4.2)$ & $2(7.4)$ & $3(11.5)$ & $1(20.0)$ \\
\hline \multicolumn{6}{|l|}{ Individual types } \\
\hline \multicolumn{6}{|l|}{ HR HPV types, } \\
\hline HPV 16 & $27(6.9)$ & $19(5.7)$ & $2(7.4)$ & $5(19.2)$ & $1(20.0)$ \\
\hline HPV 18 & $3(0.8)$ & $2(0.6)$ & $1(3.7)$ & -- & -- \\
\hline HPV 31 & $1(0.3)$ & $1(0.3)$ & -- & -- & -- \\
\hline HPV 39 & $2(0.5)$ & $2(0.6)$ & -- & -- & -- \\
\hline HPV 45 & $11(2.8)$ & $6(1.8)$ & $1(3.7)$ & $1(3.9)$ & $3(60.0)$ \\
\hline HPV 51 & $9(2.3)$ & $6(1.8)$ & $1(3.7)$ & $2(7.7)$ & -- \\
\hline HPV 52 & $4(1.0)$ & $2(0.6)$ & -- & $2(7.7)$ & -- \\
\hline HPV 56 & $1(0.3)$ & $1(0.3)$ & -- & -- & -- \\
\hline HPV 59 & $2(0.5)$ & $1(0.3)$ & $1(3.7)$ & -- & -- \\
\hline \multicolumn{6}{|l|}{ Non HR HPV types } \\
\hline HPV 6 & $5(1.3)$ & $2(0.6)$ & $1(3.7)$ & $2(7.7)$ & -- \\
\hline HPV 11 & $2(0.5)$ & $1(0.3)$ & $1(3.7)$ & -- & -- \\
\hline HPV 26 & $1(0.3)$ & -- & $1(3.7)$ & -- & -- \\
\hline HPV 30 & $3(0.8)$ & $2(0.6)$ & -- & $1(3.9)$ & -- \\
\hline HPV 40 & $1(0.3)$ & $1(0.3)$ & -- & -- & -- \\
\hline HPV 42 & $1(0.3)$ & $1(0.3)$ & -- & -- & -- \\
\hline HPV 43 & $1(0.3)$ & $1(0.3)$ & -- & -- & -- \\
\hline HPV 54 & $1(0.3)$ & $1(0.3)$ & -- & -- & -- \\
\hline HPV 66 & $7(1.8)$ & $6(1.8)$ & -- & $1(3.9)$ & -- \\
\hline HPV 67 & $3(0.8)$ & -- & $2(7.4)$ & $1(3.9)$ & -- \\
\hline HPV 70 & $2(0.5)$ & -- & -- & $2(7.7)$ & -- \\
\hline HPV 74 & $1(0.3)$ & $1(0.3)$ & -- & -- & -- \\
\hline HPV 81 & $1(0.3)$ & -- & $1(3.7)$ & -- & -- \\
\hline HPV 82 & $3(0.8)$ & $3(0.9)$ & -- & -- & -- \\
\hline HPV 87 & $7(1.8)$ & $6(1.8)$ & -- & $1(3.9)$ & -- \\
\hline HPV 89 & $1(0.3)$ & $1(0.3)$ & -- & -- & -- \\
\hline HPV 90 & $4(1.0)$ & $1(0.3)$ & $1(3.7)$ & $1(3.9)$ & $1(20.0)$ \\
\hline HPV 91 & $3(0.8)$ & $3(0.9)$ & -- & -- & -- \\
\hline
\end{tabular}


Table 3. Association between background characteristics and any HPV infection.

\begin{tabular}{|c|c|c|c|c|c|c|c|c|}
\hline \multirow{2}{*}{$\begin{array}{c}\text { Background } \\
\text { characteristics }\end{array}$} & \multicolumn{4}{|c|}{ Total } & \multicolumn{4}{|c|}{ HIV negative/MSW } \\
\hline & n (\%) & p-value & $\begin{array}{c}\text { Unadjusted } \\
\text { OR } \\
\text { (95\% CI) }\end{array}$ & $\begin{array}{l}\text { Adjusted OR } \\
(95 \% \mathrm{CI})^{\mathrm{c}}\end{array}$ & n (\%) & p-value & $\begin{array}{c}\text { Unadjusted } \\
\text { OR } \\
(95 \% \mathrm{CI})\end{array}$ & $\begin{array}{l}\text { Adjusted OR } \\
(95 \% \mathrm{CI})^{\mathrm{d}}\end{array}$ \\
\hline \multicolumn{2}{|l|}{ Age ( $\mathrm{n}=43$ missing) } & $0.6374^{\mathrm{a}}$ & & & & $0.5062^{\mathrm{a}}$ & & \\
\hline $18-24$ & $12(16.9)$ & & Ref & Ref & $10(14.7)$ & & Ref & Ref \\
\hline $25-29$ & $10(12.5)$ & & $\begin{array}{c}0.70 \\
(0.28,1.74) \\
\end{array}$ & $\begin{array}{c}0.80 \\
(0.31,2.08) \\
\end{array}$ & $8(10.4)$ & & $\begin{array}{c}0.67 \\
(0.25,1.82)\end{array}$ & $\begin{array}{c}0.75 \\
(0.27,2.07)\end{array}$ \\
\hline $30-34$ & $18(21.2)$ & & $\begin{array}{c}1.32 \\
(0.59,2.97) \\
\end{array}$ & $\begin{array}{c}1.52 \\
(0.62,3.70)\end{array}$ & $17(20.7)$ & & $\begin{array}{c}1.52 \\
(0.64,3.58) \\
\end{array}$ & $\begin{array}{c}1.79 \\
(0.72,4.46) \\
\end{array}$ \\
\hline $35-39$ & $10(20.0)$ & & $\begin{array}{c}1.23 \\
(0.49,3.12)\end{array}$ & $\begin{array}{c}1.27 \\
(0.44,3.69)\end{array}$ & $8(17.0)$ & & $\begin{array}{c}1.19(0.43 \\
3.28)\end{array}$ & $\begin{array}{c}1.51 \\
(0.51,4.45)\end{array}$ \\
\hline $40+$ & $12(19.7)$ & & $\begin{array}{c}1.20 \\
(0.50,2.92)\end{array}$ & $\begin{array}{c}1.52 \\
(0.56,4.17)\end{array}$ & $9(16.1)$ & & $\begin{array}{c}1.11 \\
(0.42,2.96)\end{array}$ & $\begin{array}{c}1.57 \\
(0.54,4.55)\end{array}$ \\
\hline \multicolumn{2}{|c|}{ Reported sexual orientation } & $<0.0001^{\mathrm{a}}$ & & & & & & \\
\hline MSW & $19(61.3)$ & & Ref & Ref & & & & \\
\hline MSM & $63(17.6)$ & & $\begin{array}{c}7.44 \\
(3.44,16.10)\end{array}$ & $\begin{array}{c}5.05 \\
(1.46,17.45)\end{array}$ & & & & \\
\hline \multicolumn{2}{|c|}{$\begin{array}{l}\text { Age at sexual debut } \\
(\mathrm{n}=48 \text { missing })\end{array}$} & $0.1584^{\mathrm{a}}$ & & & & $0.3233^{a}$ & & \\
\hline$<16$ & $16(25.0)$ & & $\begin{array}{c}2.03 \\
(0.85,4.88)\end{array}$ & $\begin{array}{c}2.35 \\
(0.85,6.46)\end{array}$ & $13(22.0)$ & & $\begin{array}{c}1.88 \\
(0.74,4.79)\end{array}$ & $\begin{array}{c}2.43 \\
(0.83,7.06)\end{array}$ \\
\hline $16-19$ & $32(15.5)$ & & $\begin{array}{c}1.12 \\
(0.52,2.40)\end{array}$ & $\begin{array}{c}1.23 \\
(0.54,2.79)\end{array}$ & $30(14.9)$ & & $\begin{array}{c}1.16 \\
(0.52,2.59)\end{array}$ & $\begin{array}{c}1.33 \\
(0.57,3.10)\end{array}$ \\
\hline $20+$ & $10(14.1)$ & & Ref & Ref & $9(13.0)$ & & Ref & Ref \\
\hline \multicolumn{2}{|c|}{$\begin{array}{l}\text { Number of lifetime sexual partners } \\
(\mathrm{n}=50 \text { missing) }\end{array}$} & $0.1470^{\mathrm{a}}$ & & & & $0.1011^{a}$ & & \\
\hline $0-5$ & $8(11.8)$ & & Ref & Ref & $8(11.8)$ & & Ref & Ref \\
\hline $6-10$ & $14(18.0)$ & & $\begin{array}{c}1.64 \\
(0.64,4.19)\end{array}$ & $\begin{array}{c}1.40 \\
(0.53,3.66)\end{array}$ & 13 (16.9) & & $\begin{array}{c}1.52 \\
(0.59,3.93)\end{array}$ & $\begin{array}{c}1.32 \\
(0.49,3.52)\end{array}$ \\
\hline $11-20$ & $17(25.8)$ & & 2.60 & 1.95 & $16(25.4)$ & & 2.55 & 2.16 \\
\hline
\end{tabular}




\begin{tabular}{|c|c|c|c|c|c|c|c|c|}
\hline & & & $(1.04,6.54)$ & $(0.72,5.28)$ & & & $(1.01,6.48)$ & $(0.79,5.90)$ \\
\hline$>20$ & 19 (14.8) & & $\begin{array}{c}1.31 \\
(0.54,3.17)\end{array}$ & $\begin{array}{c}0.82 \\
(0.30,2.26)\end{array}$ & $15(12.5)$ & & $\begin{array}{c}1.07 \\
(0.43,2.68)\end{array}$ & $\begin{array}{c}0.83 \\
(0.30,2.30)\end{array}$ \\
\hline \multicolumn{2}{|c|}{$\begin{array}{l}\text { Prevalent urethral chlamydia } \\
\text { infection }\end{array}$} & $1.0000^{\mathrm{b}}$ & & & & $0.7548^{\mathrm{b}}$ & & \\
\hline No & 78 (21.1) & & Ref & Ref & 48 (15.4) & & Ref & Ref \\
\hline Yes & $4(19.1)$ & & $\begin{array}{c}0.88 \\
(0.29,2.68)\end{array}$ & $\begin{array}{c}1.09 \\
(0.33,3.59)\end{array}$ & 4 (19.1) & & $\begin{array}{c}1.29 \\
(0.42,4.00)\end{array}$ & $\begin{array}{c}1.08 \\
(0.33,3.59)\end{array}$ \\
\hline \multicolumn{2}{|c|}{$\begin{array}{l}\text { Reported history of chlamydia } \\
\text { infection ( } \mathrm{n}=49 \text { missing) }\end{array}$} & $0.8706^{\mathrm{a}}$ & & & & $0.4563^{a}$ & & \\
\hline No & 41 (17.2) & & Ref & Ref & 38 (16.5) & & Ref & Ref \\
\hline Yes & $17(16.5)$ & & $\begin{array}{c}0.95 \\
(0.51,1.77)\end{array}$ & $\begin{array}{c}0.76 \\
(0.38,1.51)\end{array}$ & $13(13.3)$ & & $\begin{array}{c}0.77 \\
(0.39,1.53)\end{array}$ & $\begin{array}{c}0.65 \\
(0.32,1.34)\end{array}$ \\
\hline \multicolumn{2}{|l|}{ HIV status } & $0.0002^{\mathrm{a}}$ & & & & & & \\
\hline HIV negative & 67 (18.7) & & Ref & & & & & \\
\hline HIV positive & $15(46.9)$ & & $\begin{array}{c}3.83 \\
(1.82,8.06)\end{array}$ & & & & & \\
\hline
\end{tabular}


In Table 2 the distribution of HPV types in the study populations is presented. Among the 332 HIV-negative MSW, HPV positivity in the anal samples was $15.7 \%(n=52)$, with 9.6\% (n=32), 8.1\% (n=27) and 4.5\% (n=14) prevalences for oncogenic, non-oncogenic or multiple HPV types, respectively. In the entire study population of 390 men, the overall prevalence of any HPV type, HR-HPV type, low-risk (LR)-HPV and multiple type-infections in the anal canal was $21.0 \%(n=82), 12.6 \%(n=49), 11.0 \%(n=11)$ and $5.1 \%(n=20)$, respectively. Higher overall HPV prevalence was found among the 27 HIV-positive MSW (40.7\%, n=11), the 26 HIV-negative MSM (57.7\%, n=15) and the 5 HIV-positive MSM $(80.0 \%, n=4)$. The same trends were observed for oncogenic, non-oncogenic and multiple HPV infections.

The 5 most common anal HPV types among Russian HIV-negative MSW were HPV16 (5.7\%), HPV45, HPV51, HPV66 and HPV87 (1.8\% each). The same types were the most common in the whole population (Table 2). Ten HPV types, four high-risk $(33,35,58$ and $68)$ and six low-risk $(43,53,61,73,83$ and 86$)$ were not detected at all. Four of HPV types (types 26, 67, 70 and 81) were not detected among HIV-negative MSW. HPV16 was the most common type also among HIV-positive MSW (7.4\%, n=2) and HIV-negaotive MSM $(19.2 \%, \mathrm{n}=5)$.

In the multivariate analysis, few determinants of HPV infection were found. The unadjusted odds of any HPV infection was 7.4 (95\% CI: 3.4, 16.1) for MSM compared to MSW (Table 3). Overall, sexual orientation was strongly associated with HPV-positivity $(\mathrm{p}<0.0001)$ but not the number of lifetime sexual partners $(\mathrm{p}=0.147)$. Oncogenic and multiple HPVs were more often diagnosed in HIV+ than in HIV- men as well as more often among MSM than among MSW. No associations for the age of participants at the time they were enrolled in the study $(\mathrm{p}=0.6374)$ or had their sexual debut $(0.1470)$ were observed. HIV-positive men compared to HIV-negative had unadjusted increased odds of any HPV infection (3.8 (95\% CI: 1.8, 8.1). In the multivariate model, only sexual orientation remained significant while HIV status was not included because of too few observations (Table 3).

STIs were more often diagnosed among MSM than MSW. Among the visitors of the urology unit, recently diagnosed STIs were present in 48 (9.6\%) males. Among them, the most common STI was C. trachomatis, detected in the urethra of 10.8\% (36 out of 332) MSWs and 23.1\% (6/26) MSMs, and in the anal canal of 15.4\% (4/26) MSM. Three urethral samples were positive for HSV, all from MSW. One MSW was HIV positive. N. gonorrhoeae 
was found in the distal urethra of two Chlamydia-positive men, one each MSW and MSM, and in the anal canal of one Chlamydia-positive MSM. Prevalent and past $C$. trachomatis infection had no association with the detection of HPV in the current study (p=1.0). Among patients from the city infectious disease hospital, HIV positivity was confirmed in all of them at the study entry with no other STIs detected in the urethral or anal samples.

No visible anogenital warts were present in the studied population. Genital warts were found in $5(1.3 \%)$ HIV-negative MSW. The anal swabs were positive for HPVs in 2 of these men (HPV16 and HPV87 in one man and HPV51 in another) and were negative for 3 of them.

\section{Discussion}

The current study includes the so far largest cohort of heterosexual HIV-negative men in the Eastern hemisphere and the first in Europe, using broad HPV genotyping. The high prevalence of anal HPV in Russian HIV-negative MSW (15.7\%) is in line with studies from the Western hemisphere (in Brazil, Mexico and the USA) that have reported 12.0-17.6\% prevalence of anal canal HPV infection among sexually active MSW 4-7,18,19.

This study extends the knowledge on HPV genotype distribution in the anal canal as comparative studies of anal HPVs in which MSM and MSW are recruited from the same population have been lacking ${ }^{8}$. Also, this study is the first to actually perform HIV testing for all study subjects rather than relying on self-reported ${ }^{8}$ HIV status.

In accordance with the original reports from San Francisco 20 and Korea 11, the substantially higher prevalence of anogenital HPV in HIV-infected compared to HIVuninfected individuals were confirmed in the current study, both for any $(p=0.0002)$ or oncogenic only ( $p=0.0109)$ HPVs. Anal HPV infection in HIV-positive men is of great clinical interest: although HIV is no longer a fatal disease, anal malignancy is a relatively common consequence of anal infection with HR-HPVs ${ }^{21}$ and a common comorbidity related to the HIV-positive status. HIV acquisition is associated with presence of the HPV 22. Screening for anal cancer is recommended for all HIV-infected men, regardless of their sexual orientation ${ }^{23}$ as presence of any HPV type is more than 3 times as common among HIV-positive as compared to HIV-negative subjects ${ }^{9}$. In Russia, UNAIDS reported the adult HIV prevalence to be $1.1 \%$, with an increase in HIV distribution predominantly affecting drug users and heterosexuals ${ }^{24}$. As the majority of participants reported to have a known 
HIV status, this probably explains that fact why only a single case of unexpected HIV infection was found in the study.

In the multivariate model, reported sexual orientation remained significantly associated with HPV infection. In the current study, the vast majority of Russian men reported male-female sex only. Among the HIV-negative visitors of the urology clinic, 6.7\% reported being MSM were comparable to $4.2-13.2 \%$ in prospective studies among men not selected for sexual orientation $6,7,25$. While a participant with less than 3 lifetime male anal sex partners may still considered as MSW 7, in this study all men reported any oral or anal sex with men were classified as MSM. Anal HPV positivity within this small group was relatively high: up to $60 \%$ in HIV-negative and $80 \%$ in HIV-positive MSM. In fact, HPVs can be detected more than 6 times as common among men who identified themselves as MSM as compared to $\mathrm{MSW}^{9}$. Also, specimens with cytological abnormalities were also found more often HPV-positive in MSM (92\%) compared to MSW (65\%) by others ${ }^{23}$. At the anal site, MSM have a higher HPV prevalence, higher incidence rate and a lower clearance rate than do heterosexuals ${ }^{26}$. Most of the anal infections in MSM are caused by multiple HPV types ${ }^{26}$. Also in the current study multiple HPV infection was found in a quarter of the studied MSM.

It is not clear how MSW acquire anal HPV. Contrary to the role of the female anus for female-to-male HPV transmission, the male anus is not a major source of male-to-female transmission of the virus 27. The first investigation among MSW in 1994 found HPV infection to be a multi-centric genital and anorectal event, with HPV positivity of $28 \%$ at either genital and anorectal regions (65\% vs 35\% of the genital vs anorectal specimens, respectively) ${ }^{28}$. Subsequent studies, mostly concentrated on high-risk groups, such as MSM or HIV-positive men, reported that number of female sex partners in MSW was associated but number of male anal sex partners in MSM was not associated with genital HPV ${ }^{8}$. The present study found no association between the numbers of lifetime sexual partners among MSW and anal HPV infection. Limited studies among MSW speculate about possible finger-genital transmission with self-inoculation events or from a sexual partner ${ }^{27,29}$. In the current study men were not asked about the details of their routine sexual practice or preferences (i.e., if they involve anal touching, fingering, use of sex toys, etc.), since collecting such information would have many limitations and could have resulted in biases, based on cultural differences in approaching such topics. 
Data on incidence, prevalence and clearance of HPV infection in men are essential for the development of models estimating the effect of male HPV vaccination ${ }^{25}$. Such knowledge should be extended with studies on HPV transmission routes in different male populations, risk-factors of acquiring the virus, and its transmission between different anatomical areas. In the current study only beta-globin positive samples were tested for the presence of HPV DNA. However, the presence of HPV DNA does not necessarily indicate presence of infectious virus ${ }^{23,30-32}$ but may be the result of transient deposition or different than sexual route of transmission. Interestingly, a recent survey found a high HPV DNA prevalence on environmental surfaces (toilet seats) suggesting that some of the presence of HPV DNA may have resulted from contact with HPV on environmental surfaces or other non-sexual transmission routes ${ }^{31}$. Since the presence of HPV DNA does not necessarily indicate presence of infectious virus, those findings were not regarded as evidence regarding possible routes of HPV transmission ${ }^{31}$. However, more studies in this area would be of great interest as HPV particles deposited on environmental surfaces have been reported to stay infectious up to 7 days ${ }^{33}$.

It is well-established that immunocompromised individuals with HIV are at increased risk of HPV-related disease compared with those who are immunocompetent ${ }^{34,35}$. Among another potential explanations why HPVs are more commonly detected in HIV-positive MSM can be that HIV-associated disruption of mucosal epithelial tight junctions potentiates HPV infection could be ${ }^{36}$. Such disruption may happen during the anal intercourse or touching, or even during the shift in composition of anal microbial community in MSMs caused by the advanced infection with HIV and related treatment, partially attributable to antibiotics ${ }^{37}$. A known HIV status, together with the data on sexual orientation, made possible a multivariate analysis. However, a limitation is that the sample sizes of some of these groups were relatively small. Since homosexuality remains a stigmatized topic, conducting studies among MSMs in Russia is complicated. However, a single study reported 6\% of HIV prevalence among Russian MSM ${ }^{38}$, while in 2014, the Russian Federal AIDS Centre reported that only 1.2\% of HIV transmission was associated with male-to-male sexual intercourse between men ${ }^{39}$. HIV acquisition is reportedly associated with presence of HPV infection ${ }^{22}$, which is detected more often in MSM than MSW. A study among 123 Russian MSM reported that HPV types 16 and 18 were more prevalent in HIV seropositive than seronegative men (41.4\% vs $23.1 \%$; $=0.03$ ) ${ }^{40}$. HPV 
vaccination among young boys (e.g., in piloted HPV vaccination programmes ${ }^{40}$ ) is one of the possible approaches to reduce HPV (and potentially also HIV) acquisition.

Our lack of data on condom use is another potential limitation. Improper use of condoms was among the main reasons why the non-high-risk group men sought STI testing in the current study. Data on smoking, anal cytology and proctoscopy would be beneficial in the studies on anal cancer screening. Smoking was earlier not associated with oncogenic HPV in multivariate analysis ${ }^{8}$. Since circumcision is not common among Russian men, this data was not included in the survey: HPV prevalence has been reported not to vary by circumcision status ${ }^{27}$, which is marginally associated with anal HPV infection 5 .

The most commonly detected HPV type in the anal canal has been reported to be HPV16, although it had a conspicuous prevalence difference in its different populations (7.2\%, to $1.5 \%$ and $1.4 \%$ in USA (Tampa), Brazil (San Paolo) and Mexico (Cuernavaca), respectively $(\mathrm{p}<0.001))^{6}$. In Russia (St. Petersburg), HPV type 16 was also the most commonly detected in the anal canal (5.7\%-6.9\%).

Data on relation of anal HPV to age has been inconsistent. One study reported the highest prevalence of anal HPV infections around 35 years of age in HIV-positive MSM ${ }^{41}$. We found no association neither with age of participants at the time of the study and the age at their sexual debut. Our results are more in accordance with the HIM study, which reported no age association with incidence or clearance of genital HPV infection in men 25 .

In summary, anal HPV infection is relatively common (15\%) in Russian heterosexual men. Anal HPV prevalence are higher among MSM, where also multiple HPV infection is

very common. Sexual orientation was the only significant risk factor for anal HPV presence in multivariate analysis. The results obtained from a STI clinic are however not representative for the general population and further studies are necessary.

Continued studies are needed for a better understanding of HPV epidemiology and natural history in men, its role in the development of anal malignancy in men, transmission between sexual partners and monitoring of HPV vaccination effects.

\section{Funding}

This work was supported by the Swedish Cancer Society (Scholarship 2011 to V. Smelov) and, in part, by a United Nations Educational, Scientific and Cultural Organization (UNESCO)-American Society for Microbiology (ASM) International Travel Award (to V. 
Smelov, 2006). The work was in part undertaken during the tenure of a postdoctoral fellowship from the International Agency for Research on Cancer, partially supported by the European Commission FP7 Marie Curie Actions - People - Co-funding of regional, national, and international programmes (COFUND) (to V. Smelov, 2013). The funders had no role in study design, data collection, and analysis.

\section{Acknowledgments}

The authors are thankful to all participants. The authors are also grateful to the personnel of the St. Petersburg State University Outpatient clinic, D.O. Ott Research Institute of Obstetrics and Gynaecology, S. P. Botkin Memorial Clinical Hospital of Infectious Diseases and North-Western State Medical University named after I.I. Mechnikov (all St. Petersburg, Russia) for their dedicated administrative and technical support. The authors are grateful to Dr. Rolando Herrero for careful reading and comments.

\section{Conflict of interests.}

None.

\section{References}

1. Forman D, de Martel C, Lacey CJ, et al. Global burden of human papillomavirus and related diseases. Vaccine. 2012;30 Suppl 5:F12-23.

2. Jemal A, Simard EP, Dorell C, et al. Annual Report to the Nation on the Status of Cancer, 1975-2009, featuring the burden and trends in human papillomavirus(HPV)associated cancers and HPV vaccination coverage levels. J Natl Cancer Inst. 2013;105(3):175-201.

3. Machalek DA, Poynten M, Jin F, et al. Anal human papillomavirus infection and associated neoplastic lesions in men who have sex with men: a systematic review and meta-analysis. Lancet Oncol. 2012;13(5):487-500.
4. Giuliano AR, Nielson CM, Flores R, et al. The optimal anatomic sites for sampling heterosexual men for human papillomavirus (HPV) detection: the HPV detection in men study. J Infect Dis. 2007;196(8):1146-1152.

5. Nyitray A, Nielson CM, Harris RB, et al. Prevalence of and risk factors for anal human papillomavirus infection in heterosexual men. $J$ Infect Dis. 2008;197(12):16761684.

6. Nyitray AG, Smith D, Villa L, et al. Prevalence of and risk factors for anal human papillomavirus infection in men who have sex with women: a cross-national study. $J$ Infect Dis. 2010;201(10):14981508. 
7. Nyitray AG, Carvalho da Silva RJ, Baggio ML, et al. Age-specific prevalence of and risk factors for anal human papillomavirus (HPV) among men who have sex with women and men who have sex with men: the HPV in men (HIM) study. J Infect Dis. 2011;203(1):4957.

8. Nyitray AG, da Silva RJC, Baggio ML, et al. The prevalence of genital HPV and factors associated with oncogenic HPV among men having sex with men and men having sex with women and men: the HIM study. Sex Transm Dis. 2011;38(10):932-940.

9. Colón-López V, Ortiz AP, Del ToroMejías L, Clatts MC, Palefsky JM. Epidemiology of anal HPV infection in high-risk men attending a sexually transmitted infection clinic in Puerto Rico. PloS One. 2014;9(1):e83209.

10. Melo VH, Guimaraes MDC, Rocha GM, et al. Prevalence and risk factors associated with anal intraepithelial neoplasia among HIV-positive men in Brazil. J Low Genit Tract Dis. 2014;18(2):128135.

11. Lee CH, Lee SH, Lee S, et al. Anal Human Papillomavirus Infection among HIV-Infected Men in Korea. PloS One. 2016;11(8):e0161460.

12. International HPV Reference Center. References clones. http://www.nordicehealth.se/hpv center/reference_clones/. Accessed June 16, 2017.

13. Schmitt M, Bravo IG, Snijders PJF, Gissmann L, Pawlita M, Waterboer T. Bead-based multiplex genotyping of human papillomaviruses. J Clin Microbiol. 2006;44(2):504-512.
14. Söderlund-Strand A, Carlson J, Dillner J. Modified general primer PCR system for sensitive detection of multiple types of oncogenic human papillomavirus. J Clin Microbiol. 2009;47(3):541-546.

15. De Vuyst H, Clifford GM, Nascimento MC, Madeleine MM, Franceschi S. Prevalence and type distribution of human papillomavirus in carcinoma and intraepithelial neoplasia of the vulva, vagina and anus: a metaanalysis. Int J Cancer J Int Cancer. 2009;124(7):1626-1636.

16. Smelov V, Quint KD, Pleijster J, et al. Chlamydia trachomatis serovar distributions in Russian men and women: a comparison with Dutch serovar distributions. Drugs Today Barc Spain 1998. 2009;45 Suppl B:33-38.

17. Eklund C, Forslund O, Wallin K-L, Dillner J. Global improvement in genotyping of human papillomavirus DNA: the $2011 \mathrm{HPV}$ LabNet International Proficiency Study. J Clin Microbiol. 2014;52(2):449-459.

18. Nielson CM, Flores R, Harris RB, et al. Human papillomavirus prevalence and type distribution in male anogenital sites and semen. Cancer Epidemiol Biomark Prev Publ Am Assoc Cancer Res Cosponsored Am Soc Prev Oncol. 2007;16(6):1107-1114.

19. Sudenga SL, Nyitray AG, Torres BN, et al. Comparison of anal HPV natural history among men by country of residence: Brazil, Mexico, and the United States. $J$ Infect. 2017;75(1):35-47.

20. Palefsky JM, Holly EA, Ralston ML, Jay N. Prevalence and risk factors for human papillomavirus infection of the anal canal in human immunodeficiency virus 
(HIV)-positive and HIV-negative homosexual men. J Infect Dis. 1998;177(2):361-367.

21. IARC Monographs on the Evaluation of Carcinogenic Risks to Humans, Volume 100 B, Biological Agents. Lyon: IARC; 2012.

22. Lissouba $P$, Van de Perre $P$, Auvert B. Association of genital human papillomavirus infection with HIV acquisition: a systematic review and meta-analysis. Sex Transm Infect. 2013;89(5):350-356.

23. Darwich L, Videla S, Cañadas M-P, et al. Distribution of human papillomavirus genotypes in anal cytological and histological specimens from HIV-infected men who have sex with men and men who have sex with women. Dis Colon Rectum. 2013;56(9):10431052.

24. UNAIDS. HIV and AIDS estimates and data, 2007 and 2001. http://data.unaids.org/pub/global report/2008/jc1510_2008_global_ report_pp211_234_en.pdf. Accessed June 16, 2017.

25. Giuliano AR, Lee J-H, Fulp W, et al. Incidence and clearance of genital human papillomavirus infection in men (HIM): a cohort study. Lancet Lond Engl. 2011;377(9769):932940.

26. Videla S, Darwich L, Cañadas M-P, et al. Natural history of human papillomavirus infections involving anal, penile, and oral sites among HIV-positive men. Sex Transm Dis. 2013;40(1):3-10.

27. Hernandez BY, Wilkens LR, Zhu X, et al. Transmission of human papillomavirus in heterosexual couples. Emerg Infect Dis. 2008;14(6):888-894.
28. Van Doornum GJ, Prins M, Juffermans LH, et al. Regional distribution and incidence of human papillomavirus infections among heterosexual men and women with multiple sexual partners: a prospective study. Genitourin Med. 1994;70(4):240246.

29. Sonnex C, Strauss S, Gray JJ. Detection of human papillomavirus DNA on the fingers of patients with genital warts. Sex Transm Infect. 1999;75(5):317-319.

30. Strauss S, Sastry P, Sonnex C, Edwards S, Gray J. Contamination of environmental surfaces by genital human papillomaviruses. Sex Transm Infect. 2002;78(2):135138.

31. Smelov V, Eklund C, Arroyo Mühr LS, Hultin E, Dillner J. Are human papillomavirus DNA prevalences providing high-flying estimates of infection? An international survey of HPV detection on environmental surfaces. Sex Transm Infect. 2013;89(8):627.

32. Di Bonito P, Della Libera S, Petricca $S$, et al. A large spectrum of alpha and beta papillomaviruses are detected in human stool samples. J Gen Virol. 2015;96(Pt 3):607-613.

33. Roden RB, Lowy DR, Schiller JT. Papillomavirus is resistant to desiccation. J Infect Dis. 1997;176(4):1076-1079.

34. Piketty C, Selinger-Leneman $\mathrm{H}$, Grabar S, et al. Marked increase in the incidence of invasive anal cancer among HIV-infected patients despite treatment with combination antiretroviral therapy. AIDS Lond Engl. 2008;22(10):1203-1211.

35. D’Souza G, Wiley DJ, Li X, et al. Incidence and epidemiology of 
anal cancer in the multicenter AIDS cohort study. J Acquir Immune Defic Syndr 1999. 2008;48(4):491499.

36. Tugizov SM, Herrera R, Chin-Hong $P$, et al. HIV-associated disruption of mucosal epithelium facilitates paracellular penetration by human papillomavirus. Virology. 2013;446(1-2):378-388.

37. Yu G, Fadrosh D, Ma B, Ravel J, Goedert JJ. Anal microbiota profiles in HIV-positive and HIV-negative MSM. AIDS Lond Engl. 2014;28(5):753-760.

38. van Griensven F, de Lind van Wijngaarden JW, Baral S, Grulich A. The global epidemic of HIV infection among men who have sex with men. Curr Opin HIV AIDS. 2009;4(4):300-307.

39. Russian AIDS Center. Федеральный Центр СПИД (in Russian).

http://www.hivrussia.ru/. Accessed August 1, 2017.

40. Wirtz AL, Zelaya CE, Peryshkina A, et al. Anal human papillomavirus and HIV: A cross-sectional study among men who have sex with men in Moscow, Russia, 20122013. Euro Surveill. 2015;20(15).

41. del Amo J, González C, Geskus RB, et al. What drives the number of high-risk human papillomavirus types in the anal canal in HIVpositive men who have sex with men? J Infect Dis. 2013;207(8):1235-1241. 


\section{Chapter 9}

\section{General discussion}


This thesis elaborates on the epidemiology, diagnostic and public health aspects of the two most common bacterial and viral sexually transmitted infections, Chlamydia trachomatis $(\mathrm{Ct})$ and human papillomavirus (HPV) respectively. The studies bring together the clinical specimens of Russian and international origin and employed Dutch and international expertise, to provide insight and results of clinical and scientific importance for the public health specialists worldwide.

Short overviews of each study are given for context, followed by the discussions grouped for chlamydia and HPV infections that are focused on the epidemiological, diagnostic and public health aspects of studies, and finally, concluding remarks are provided.

\section{PART I. Chlamydia trachomatis infection}

\section{What Part I of the thesis adds to the current State of the Art}

All available data on the prevalence of $C$. trachomatis infections in the Russian Federation was reviewed and analysed. In addition, data on chlamydia serovar and strain distributions among the populations in Russia, the Netherlands and worldwide was compared and analysed. Furthermore, the role of serological markers in detection and management of Ct LGV infections was investigated and clinical recommendations were provided.

\section{Prevalence of genital Chlamydia trachomatis infections in Russia: systematic literature review and multicenter study (Chapter 2)}

A reliable overview of data on the prevalence of Chlamydia trachomatis $(\mathrm{Ct})$ in the Russian Federation was lacking. The first systematic literature review of all available studies revealed that the overall prevalence of genital Ct infections in Russian populations ranged from $2.9 \%$ to $33 \%$. The multicenter study from St. Petersburg extended the review and revealed the risk factors for Ct infections: having symptoms $(\mathrm{P}=0.004$; in men $\mathrm{P}<0.001)$, being younger than 30 years $(\mathrm{P}=0.001)$ and MSM $(\mathrm{P}=0.0084)$. Underrepresentation of MSM populations in all studies was observed. Higher Ct prevalence was observed in the groups where urethral and prostate secretion samples were pooled. Ct detection with Russian tests in St. Petersburg yielded levels of reliability comparable with internationally available tests. The initiation of screening programmes for Ct targeting high-risk 
populations in Russia could be recommended, also in an attempt to reduce the increasing HIV infection in the country.

\section{Chlamydia trachomatis serovar distributions in Russian men and women: a comparison with Dutch serovar distributions (Chapter 3)}

The data on serovar distributions of Ct are important for epidemiologic purposes and transmission studies but was completely lacking in Russia. Data on Ct serogroup and serovar distributions in Russian men and women were determined and compared with such data obtained from the Dutch populations. On the level of Ct serogroups, no statistical differences were observed between two geographical areas. Comparable to the Dutch and similar to the worldwide data, in Russia serogroup B is the most prevalent (46\%), followed by serogroups I (33\%) and C (21\%), respectively, with comparable distributions between males and females. However, on a serovar level very significant differences were discovered (reaching up to $\mathrm{P}<0.0001$ ). The serovars B/Ba and G/Ga had higher while serovars F, H, I/Ia, J and K had lower prevalences compared with the Dutch studies. In addition, all samples found to be positive in Russia were re-confirmed in the Netherlands, which suggested the reliability of Ct detection setting in St. Petersburg.

\section{Global diversification of Chlamydia trachomatis multi-locus strain types (Chapter 4)}

The C. trachomatis (Ct) Multi Locus Sequence Typing (MLST) scheme is effective in differentiating strain types (ST), deciphering transmission patterns and treatment failure, and identifying the recombinant strains. So far, Russia was an area that had not previously been represented in $\mathrm{Ct}$ typing schemes. To expand the knowledge of the global diversification of Ct STs, Ct reference and clinical samples from Americas, Asia, Africa and Europe, extended with the a cohort of cervical samples of Russian origin, was analysed for the presence of Ct STs using MLST on the basis of housekeeping genes to study evolutionary history. While the overall number of unique STs per region was comparable across geographies, the number of STs was greater for Russia with a significantly higher ST ratio as compared to Europe or the Americas. This may reflect a higher level of sexual mixing with the introduction of STs from other regions and/or re-assortment of alleles. Some STs were found to be significantly associated with a particular geographic region. 
In addition, the higher number of recombinants were observed in the samples of European origin. This indicates potential selective pressure and/or adaptive diversification of $\mathrm{Ct}$.

\section{Delayed microbial cure of lymphogranuloma venereum (LGV) proctitis with doxycycline treatment (Chapter 5)}

Caused by chlamydia biovar L, LGV is an invasive ulcerative STI that may result in severe proctitis with irreversible anal strictures. Although its treatment requires extended antibiotic regimens as compared to non-LGV anogenital infections, the optimal treatment duration for proctitis caused by both biovars had never been studied before the anal swab specimens collected during and after treatment of Ct LGV and non-LGV proctitis with standard doxycycline regimens in Dutch MSM were screened for the traces of Ct DNA and RNA. Obtained findings provided a scientifically proven support to the recommended by the U.S. Centers for Disease Control and Prevention treatment regimens of a 21-day doxycycline regimen for LGV proctitis and a 7-day regimen for non-LGV Chlamydia proctitis.

\section{Discussion:}

\section{Epidemiological, diagnostic and public health aspects}

There is no vaccine against $\mathrm{Ct}$, the leading cause of bacterial sexually transmitted diseases worldwide, and therefore main public health efforts are focused on: i) prevention strategies, to reduce the risk of acquiring $\mathrm{Ct}$ and to reduce the development of Ct-caused complications and comorbidities in the long run, ii) early and proper detection of $\mathrm{Ct}$ infection and iii) providing the efficient treatment regimens.

Understating the epidemiological situation across the area population is essential to better plan prevention measures. In fact, albeit Ct in Russia is a reportable STI, the outbreak of STIs went out of the proper control in the 1990's as the result of tremendous social-economic challenges in the country, also affecting the health care system. As a result, a significant raise of STIs and related morbidities was observed. Although some decline in the incidence of $\mathrm{Ct}$ and some other reportable STIs was observed during the last decades, the situation with HIV still remains worrying. As STIs may fuel the HIV outbreak furthermore, screening for Ct and other STIs targeting some high-risk populations in Russia should be considered. It can be foreseen that such programs, when properly 
implemented, would be beneficial not only for the individuals screened but they would be also cost-effective for the health care system itself, as it is a case for high-income countries (1). Despite several limitations regarding the populations from the studies included in the first systematic literature review (i.e., the underrepresented of lacking such high risk populations as female sex workers (FSW) and MSM) and in a multicenter study from St. Petersburg, the revealed risk factors for Ct infections in Russia were similar to the ones reported from other geographical areas and included being symptomatic and/or younger than 30 years and/or MSM. Easing the social stigma would make the presence of MSM visible, result in improved diagnostics of STIs and strengthen the prevention of STI/HIV, from which the Russian health care system would only benefit.

The knowledge on distribution and characteristics of Ct infection across Russian populations is important for epidemiological and clinical studies. The epidemiological studies based on the extended numbers of isolates and cohorts with different risk profiles for infections as well as the spread of different variations (i.e., Ct serovars, genovars or strains) within populations can be used in amongst others transmission studies and identifying specific sexual networks. Translation of the knowledge obtained from the determination of Ct variations' distributions can also provide insight in the relation with Ct-caused morbidities and therefore may result in new opportunities for healthcare as will move the further research through the development of diagnostic markers towards the more targeted therapies and precision medicine.

The thesis has worked in that direction by conducting the pioneer studies in Russia where the distribution of Ct serovars and Ct strains among some populations was investigated and compared with the international data. During the last decades, the evolution of straining-typing techniques for Ct have progressed from identifying variations in gel electrophoresis patterns and melt curve analyses to sequencing single pathogen specific genes and MLST. The first study on Ct serotyping in Russia revealed the difference in the distribution of Ct serovars and the tendency to commonly detect double infections as compared to the studied Dutch population. Later, when MLST schemes were introduced to better track the variations of $\mathrm{Ct}$, including the samples of Russian origin revealed more abundant diversity of Ct strains that reflect sexual mixing or reassortment of existing alleles.

Epidemiological and laboratory knowledge on Ct variants has already been translated into clinical routine. A proper differentiation between chlamydia LGV and non-LGV 
biovars revealed longer persistence of chlamydia RNA in Dutch patients with LGV proctitis. The obtained findings resulted in the recommendations to apply a prolonged antibacterial regimen, to improve microbiological cure of LGV-caused proctitis. Although Ct LGV remains a public health problem among MSM populations in industrialized countries, only a single pilot study on the detection of Ct LGV among HIV-positive patients was able to conduct in Russia. Albeit based on the detection of $\mathrm{Ct}$ antibodies in the serum, the pilot study suspected the presence of a single LGV case among limited number of HIVpositive MSM patients in St. Petersburg, who all were under long-term antibacterial regimens due to the complications caused by HIV (unpublished data).

Russian samples should be included in the further epidemiological studies as the data obtained from the diverse country covering a large geographic area is of great healthcare significance.

\section{PART II. HPV infection}

\section{What Part II of the thesis adds to the current State of the Art}

The second part of this thesis focuses on the epidemiological, diagnostic and public health aspects of genital and anal HPV infections in men. Studies of the epidemiology of HPV infection in the male are essential for understanding HPV natural history, transmission dynamics and optimal uses of HPV vaccines. The studies on clinical specimens of Russian origin employed international expertise in the detection and typing of HPVs to provide the results of clinical and scientific importance for the public health specialists worldwide. Expressed prostate secretion (EPS) samples have been studied to find if EPS may represent informative sampling material for the study of HPV epidemiology in the male. The anal prevalence of extended number of mucosal $\alpha$ - and cutaneous $\beta$ - and $\gamma$-HPV types in the male anal canal have been evaluated in (mostly heterosexual) men, to better understand the determinants for the distribution and transmission routes of HPVs.

\section{Expressed prostate secretions in the study of human papillomavirus epidemiology in the male (Chapter 6)}

The presence of mucosal high-risk $\alpha$-HPV types has been studied in a variety of different anatomical sites in men but not in expressed prostate secretions (EPS), while EPS specimens have been used for assessing the bacteriological and inflammatory state of the 
lower urinary tract in men for decades. Applying the multiplexed genotyping method, the five most common $\alpha$-HPVs were types 16, 18, 45, 51 and 6 in the male distal urethra compared to HPV types 16, 66, 87, 45 and 91 in the prostate secretion specimens. The prevalence of $\alpha$-HPVs was $25.9 \%$ in the male distal urethra and $32.6 \%$ in the studied prostate specimens, with only 6.4\% samples had type-specific HPV concordance between the EPS and urethral samples. EPS were found to represent an informative sample material for the study of HPV epidemiology in men.

\section{Prevalence of cutaneous beta and gamma human papillomaviruses in the anal canal of men who have sex with women (Chapter 7)}

The number of studies on anal cutaneous HPVs is remarkably limited, and information on the anal presence and determinants of HPVs in males, especially among non-MSM populations, remains especially unclear. The prevalence of $43 \beta$ - and $29 \gamma$-HPVs in a cohort of MSW from Russia, the first such known sample in the Eastern hemisphere was evaluated using a multiplex PCR assay. Overall, the prevalence of $\beta$-HPVs and $\gamma$-HPV in the anal canal of MSW anal were $24.4 \%$ and $15.9 \%$, respectively. The three most commonly detected $\beta$-HPVs were types 110, 22 and 124, while the most common $\gamma$-HPVs were types 95, 132 and 50. For both genera, being HIV-positive at the time of testing was a significant determinant of detection, with an odds ratio of 11.46 (95\%CI: 4.92-26.69) and 7.80 (95\%CI: 3.57-17.02) for $\beta$ - and $\gamma$-HPVs, respectively. Other than penile-anal intercourse routes were suggested to be important in cutaneous HPV transmission.

\section{Determinants of presence of human papillomaviruses in the anal canal of men (Chapter 8)}

Knowledge of determinants of anal HPV infections among men remains limited as data regarding the detection of HPVs in the anal canal among HIV-positive and HIV-negative men largely relies on studies among MSM in limited geographical settings. Anal canal samples from a group of HIV-negative and HIV-positive MSW and MSM attending STI clinics in St. Petersburg were tested for presence of 13 oncogenic and 23 non-oncogenic $\alpha$-HPV types and the results were analysed. Sexual orientation (being MSM) and HIV status (being HIV-positive) were the major determinants for the presence of $\alpha$-HPV types 
in the male anal canal, although anal $\alpha$-HPVs were detected in $15.7 \%$ among HIV-negative heterosexual men.

\section{Discussion:}

\section{Epidemiological, diagnostic and public health aspects}

In a new era of developing HPV vaccination, adequate diagnostics of the viral infection in men becomes more important as it allows to evaluate whether vaccine HPV types disappear from and how the prevalence of non-vaccine types is affected in high-risk or general populations. In this respect, detection methods, anatomical sites for optimal HPV sampling and the determinants for the distribution and abundance of HPV types are of high public health interest.

The thesis includes the first study where multiplex high-throughput genotyping of an extended spectrum of $\alpha$-HPV types was applied on prostate secretion samples, analysed and compared with the paired distal urethra samples obtained from the same men, representing the male upper and lower urogenital tract, respectively. Compared to analysis of urethral samples only, the analysis of EPS increased the HPV prevalence in this population with $26.2 \%$. Penile swabs, reported to be the anatomic site with the highest published prevalence of HPV (2), were not included in the present study. However, in a study on the distribution of $\alpha$-HPVs in the three genital sites that included samples of penile, urethral and EPS origin, still not including EPS resulted in missing 13\% of HPVpositive men ( $\mathrm{p}<0.0001$; unpublished data). The prostate samples must be in the focus of the HPV studies: investigation of EPS increases the number of HPV-positive men as compared to penile and urethral samples only. Longitudinal studies could of particular interest. This will broaden our knowledge on HPV epidemiology in men and transmission dynamics and would help in further development of prevention strategies.

HPV is the most common viral STI and (anal) persistence of $\alpha$-HPV infection can result in the development of anal cancer, while the role of cutaneous $\beta$ - and $\gamma$-HPVs have not been proven. As HIV infection is one of the strongest risk factors for anal cancer, most of the studies on the detection of anal HPV were focused on the detection of $\alpha$-HPVs DNA among MSM populations. Studies on the detection of the presence of cutaneous $\beta$ - and $\gamma$ HPVs in MSM remain limited but in MSW are simply lacking. Furthermore, comparative studies on anal mucosal $\alpha$-HPVs, in which both MSM and MSW are recruited from the same population, remain very limited as well. The presented studies extend the 
knowledge on the distribution of HPV genotypes from the three HPV genera $(\alpha, \beta$ and $\gamma)$ in the male anal canal by including the so far largest cohort of heterosexual HIV-negative men in the Eastern hemisphere and the first in Europe, using broad $\alpha$ - or $\beta$ and $\gamma$-HPV genotyping assays with documented proficiency (3).

Mucosal and cutaneous HPVs were found to be relatively common in the anal canal of Russian MSW, with the overall prevalence of 15\%, 24\% and 14\% in the studied population for $\alpha-, \beta$ - and $\gamma$-HPV types, respectively. Although results obtained in the study from St. Petersburg on the anal prevalence of $\beta$ - and $\gamma$-HPVs among MSW remain novel, one can speculate that comparable results can be repeatedly obtained by the complementary studies from other geographical areas in the world, as did the study from Russia regarding the data for anal $\alpha$-HPVs. More important, contrary to MSM the routes for the transmission of HPVs into the anal canal in MSW remain unclear and should further be investigated. Interestingly, preliminary results have shown the lack of concordance between genital and anal sites for $\beta$ - and $\gamma$-HPV types in men regardless of sexual orientation, which advocates the existence of transmission routes other than penile-anal for these types of $\operatorname{HPV}(4,5)$. Presumably, self-inoculation or transmission from the partners with fingers, hands, tongue, saliva or secretions might result in the detection of HPV DNA in the anal canal of men regardless of their sexual practices, as it has been speculated for $\alpha$-HPV types in the studies within heterosexual couples $(6,7)$. First, further studies should focus on the incidence and clearance of anal HPV infections, as the presented studies, similar to others, could not distinguish between new or persistent HPV infections. Importantly, most of current epidemiological studies are based on the detection of HPV DNA in a clinical specimen, which was also the case in the reported studies. However, the presence of HPV DNA does not necessarily indicate presence of infectious virus (8-13) but may be the result of transient deposition or different than sexual route of transmission. The importance of HPV testing alone as the primary screening test has been recognized but there is a continuing need to find markers of disease progression that will help to distinguish clinically insignificant, self-limited HPV infections (which detection heavily relies on the detection of HPV DNA) from precancerous infections (14).

Knowledge on the determinants for HPV infection is important as this can help to narrow the public health measures to prevent the development of HPV-related malignancies, including anal cancer, which incidence is increasing by $2 \%$ per year among 
both genders $(15,16)$. Although limited with the number of studied determinants, some were clearly observed in the presented studies. A positive (2.7-fold) association was observed between the number of MSW's lifetime sexual partners and detection of cutaneous $\beta$-HPVs but no association was observed for other two studied HPV genera, which suggests further studies of differences in tissue tropism and pathogenicity between different HPV genera. Importantly, all three HPV genera were more common detected in the anal samples of HIV-positive compared to HIV-negative men, with the observed 3.8, 11.5 and 7.8-fold increased odds of positive outcomes for $\alpha$-, $\beta$ - and $\gamma$-HPVs, respectively. This advocates further studies among this high-risk population on the prevalence of HPVs in different geographic areas, improved diagnostics of HPV-caused malignancies as well as primary (i.e., vaccination against $\alpha$-HPVs) and secondary prevention strategies. In this respect, studies among MSM populations are of great public health concern. Current studies were unfortunately limited in enrolling a larger number of MSM due to social stigma and therefore MSM were excluded from the main analyses. However, data obtained even from the small number of Russian MSM confirmed that, in line with other published studies, being MSM is another notable risk factor for anal $\alpha$-HPV presence, with a 7.4-fold odds risks observed. Being able to target such populations will be beneficial for the public health as it leads to decline in HIV transmission and results in prevention of HPV-caused malignancies. This also implies to the Russian settings.

\section{Concluding remarks:}

\section{Chlamydia trachomatis and HPV infections}

During the last few decades much progress has been made in the management of several STIs, including Chlamydia and HPV infections, worldwide. The achievements include better understanding of the natural history of the two infections, their improved detection and typing, introduction of reporting systems and treatment guidelines for Chlamydia infections and implementation of HPV vaccination programs and HPV-based tests cancer screening programs in several countries across the globe, mostly to prevent the development of HPV-caused malignancies. Much of that progress became possible as a result of international collaborations to obtain massive and diverse epidemiological data from different world areas and populations, as epidemiology remains important in guiding public health strategies to minimise diseases burden. This progress would be also 
impossible without the knowledge transfer provided by the leading state-of-art centers and institutions located mostly in high-income countries to low- and middle-income countries (LMICs), which has resulted in the development and spread of technically advanced facilities in LMICs and saved many human lives across the glove.

The studies presented in the thesis applied international expertise in detection and typing of the most common bacterial and viral STIs on included clinical specimens of Russian origin. This resulted in the scientific and clinical outcomes important for public healthcare specialists worldwide. The thesis revealed data on the risk factors and prevalence of chlamydia infections and its novel variants within a previously underrepresented population, the determinants for the distribution of HPV types from different genera within previously untested anatomical sites by applying novel diagnostic approaches, and discovered important gaps in STI diagnostic and prevention strategies by excluding such specific subgroups as MSM.

As STIs still remain a global public health problem, further epidemiological, diagnostic and clinical research is still needed. As the history has shown, STIs have no borders. So should have the research on STIs.

\section{References}

1. ECDC. European Centre for Disease Prevention and Control. Annual Epidemiological Report 2016 - Chlamydia. [Internet]. Stockholm: ECDC; 2016 [cited 2017 August 30]. Available from: http://ecdc.europa.eu/en/healthtopics/Ch lamydia/Pages/Annual-epidemiological-re port-2016.aspx [Internet]. [cited 2017 Aug 30]. Available from:

https://ecdc.europa.eu/sites/portal/files/ documents/Chlamydia\%20AER.pdf

2. Dunne EF, Nielson CM, Stone KM, Markowitz LE, Giuliano AR. Prevalence of HPV infection among men: A systematic review of the literature. J Infect Dis. 2006 Oct 15;194(8):1044-57.

3. Eklund C, Forslund O, Wallin K-L, Dillner J. Global improvement in genotyping of human papillomavirus DNA: the $2011 \mathrm{HPV}$ LabNet International Proficiency Study. J Clin Microbiol. 2014 Feb;52(2):449-59.

4. Smelov V. Beta-HPV types in anal and genital sites among men: lack of concordance regardless of sexual orientation [Internet]. [cited 2017 Sep 6]; Cape Town, South Africa. Available from:
http://hpv2017.org/Documents/HPV\%20 2017\%20Final\%20Program\%20SPIRAL.p df

5. Smelov V, Muwonge R, Hanisch R, McKayChopin S, Eklund C, Komyakov B, et al. Gamma-HPV types in anal and genital sites among men who have sex with women: lack of concordance. In Cape Town, South Africa; [cited 2017 Sep 6]. Available from: http://hpv2017.org/Documents/HPV\%20 2017\%20Final\%20Program\%20SPIRAL.p df

6. Hernandez BY, Wilkens LR, Zhu X, Thompson P, McDuffie K, Shvetsov YB, et al. Transmission of human papillomavirus in heterosexual couples. Emerg Infect Dis. 2008 Jun;14(6):888-94.

7. Widdice L, Ma Y, Jonte J, Farhat S, Breland D, Shiboski S, et al. Concordance and transmission of human papillomavirus within heterosexual couples observed over short intervals. J Infect Dis. 2013 Apr 15;207(8):1286-94.

8. Strauss S, Sastry P, Sonnex C, Edwards S, Gray J. Contamination of environmental surfaces by genital human 
papillomaviruses. Sex Transm Infect. 2002 Apr;78(2):135-8.

9. Smelov V, Eklund C, Arroyo Mühr LS, Hultin E, Dillner J. Are human papillomavirus DNA prevalences providing high-flying estimates of infection? An international survey of HPV detection on environmental surfaces. Sex Transm Infect. 2013 Dec;89(8):627.

10. Darwich L, Videla S, Cañadas M-P, Piñol M, García-Cuyàs F, Vela S, et al. Distribution of human papillomavirus genotypes in anal cytological and histological specimens from HIV-infected men who have sex with men and men who have sex with women. Dis Colon Rectum. 2013 Sep;56(9):104352.

11. Anderson TA, Schick V, Herbenick D, Dodge B, Fortenberry JD. A study of human papillomavirus on vaginally inserted sex toys, before and after cleaning, among women who have sex with women and men. Sex Transm Infect. 2014 Nov;90(7):529-31.

12. Gallay C, Miranda E, Schaefer S, Catarino R, Jacot-Guillarmod M, Menoud P-A, et al.
Human papillomavirus (HPV) contamination of gynaecological equipment. Sex Transm Infect. 2015 Jun 12 ;

13. Di Bonito P, Della Libera $S$, Petricca $S$, Iaconelli M, Sanguinetti M, Graffeo R, et al. A large spectrum of alpha and beta papillomaviruses are detected in human stool samples. J Gen Virol. 2015 Mar;96(Pt 3):607-13.

14. Burd EM. Human Papillomavirus Laboratory Testing: the Changing Paradigm. Clin Microbiol Rev. 2016 Apr;29(2):291-319.

15. Johnson LG, Madeleine MM, Newcomer LM, Schwartz SM, Daling JR. Anal cancer incidence and survival: the surveillance, epidemiology, and end results experience, 1973-2000. Cancer. 2004 Jul 15;101(2):281-8.

16. Cancer of the Anus, Anal Canal, and Anorectum - SEER Stat Fact Sheets [Internet]. [cited 2015 Jun 4]. Available from:

http://seer.cancer.gov/statfacts/html/anu s.html 
Summary 


\section{Summary}

Worldwide, Chlamydia trachomatis and HPV infections are the leading bacterial and viral causes of sexually transmitted diseases. The two are of great public health importance, as untreated chlamydia may result in infertility and ectopic pregnancy, persistent HPV may trigger the development of malignancy and both are also associated with the risk of acquiring HIV. Many infections run asymptomatically and therefore remain undetected.

To reduce the burden of diseases caused by sexually transmitted infections, multiple strategy combines prevention interventions including vaccination or screening programmes targeting risk populations, improved diagnostics and optimized clinical management. This requires better understanding of natural history, epidemiology and transmission routes, as well as optimal early detection and reliable diagnosis of the infectious agent. However, reliable figures on the prevalence and incidence of both chlamydia and HPV infections are difficult to obtain due to the nature of the pathogen or the lack of reliable information from many world areas, as a result of the variety of surveillance systems or approaching high-risk populations (i.e., stigmatizing men who have sex with men (MSM)). Better knowledge on the role of the abundance of the pathogen's variations on population or individual levels can be obtained with advanced diagnostic approaches available in state-of-art laboratory settings and transferred to the world areas lacking technical assistance or resources.

The data on the prevalence of genital chlamydia infection and the spectrum of its serological variants and strain types in the Russian populations as compared with available international data remained limited or was simply lacking. To apply the improved clinical management of chlamydia LGV infection in MSM population became possible as a result of the study performed in the Netherlands.

Relatively little remained known about the prevalence and spectrum of the HPV types in the male anogenital area, in particular among non-MSM populations.

This thesis addressed these topics in two parts.

Chapter 1 depicts the epidemiology of genital C. trachomatis and HPV infections worldwide and in Russia, provides an overview on the STI services in Russia and challenges involving the management of STIs and related research, describes aspects of prevention, diagnostic and clinical management of the infections and presents the outline of the studies described in this thesis. 


\section{Part I. Chlamydia trachomatis (Ct) infection}

The studies described in Chapters 2, 3, 4 and 5 form Part I that focuses on epidemiological and diagnostic aspects, which contribute to the improved clinical management of genital Ct infections.

In Chapter 2 we analysed all the available data on the prevalence of genital $\mathrm{Ct}$ infections in all available peer reviewed studies for Russian populations. A preformed systematic literature review revealed a total of 10 articles that met the inclusion criteria and was expanded with data from the multicenter study among 1263 people in the second-largest Russian city of St. Petersburg, testing for Ct DNA in urethral, anal, cervical, and prostate samples. The overall prevalence of genital $\mathrm{Ct}$ infections in Russian populations ranged from $2.9 \%$ to $33 \%$. The multicenter study revealed the risk factors, which included being symptomatic $(\mathrm{P}=0.004$; in men $\mathrm{P}<0.001)$, being younger than 30 years $(\mathrm{P}=0.001)$, and being MSM $(\mathrm{P}=0.0084)$. Ct prevalence was higher in the groups where urethral samples were pooled with prostate secretion samples. Ct detection with Russian tests in some settings in St. Petersburg yielded levels of reliability comparable with internationally available tests. We also suggested that prostate secretions may represent an additional sampling material for the study of $\mathrm{Ct}$ infection in men. We concluded that the initiation of screening programmes for Chlamydia targeting high-risk populations in Russia should be considered.

In Chapter 3, we determined the first Ct serogroup and serovar distribution in Russian women and men and compared them with the data obtained in the Netherlands. In the studied Russian population, comparable to that the data from the Netherlands and worldwide, serogroup B was the most prevalent (46\%), followed by serogroup I (33\%) and serogroup C (21\%), with comparable distributions between males and females. However, significant differences were observed in the serovar level distributions between the studied cohorts, i.e., a significantly higher prevalence of serovar B/Ba was observed in the Russian compared with the Dutch cohorts (5 vs. 1\%, P<0.0001; OR: 12.06, 95\%CI: 3.5-41.1). Serovar F had a decreased prevalence (8 vs. 23\%), while serovar G/Ga (25 vs. 9\%) had an increased prevalence compared to the Dutch cohorts $(\mathrm{P}<0.0001,0 \mathrm{R}: 7.4,95 \%$ CI: 3.8-14.5). The samples found to be positive in Russia were re-confirmed in the Netherlands, suggesting the reliability of Ct detection setting in St. Petersburg. The epidemiological studies based on the extended numbers of isolates and cohorts with different risk profiles for infections as well as the spread of different serovars within 
populations can be used in amongst others transmission studies and identifying specific sexual networks.

In Chapter 4 we analyzed the global diversification of Ct strain types (ST) by studying 323 reference and clinical samples from Africa, Americas, Asia and Europe, including 58 samples from Russia, an area that has not previously been represented in Ct typing schemes, with highly-valid Ct Multi Locus Sequence Typing (MLST) scheme. We found that some STs were found to be significantly $[\mathrm{p}=0.0004-0.032]$ associated with a particular geographic region. Across geographies, the number of STs was greater for Russia with a significantly higher ST/sample ratio of 0.45 (95\% CI: 0.35-0.53) compared to Europe or the Americas ( $\mathrm{p}<0.009$ ), which may reflect a higher level of sexual mixing with the introduction of STs from other regions and/or re-assortment of alleles. Of the 26 STs that contained Russian samples, 18 (69\%) were novel, which may be expected as the Russian population had not been sampled for MLST analyses before. The higher number of recombinants in Europe indicates selective pressure and/or adaptive diversification that will require additional studies to elucidate.

In Chapter 5 we evaluated the microbial cure of Chlamydia LGV and non-LGV with doxycycline treatment by testing for Ct DNA and RNA persistence in Dutch MSM anal swab specimens, as the optimal treatment duration for proctitis caused by Ct serovar $\mathrm{L}$, that causes endemic among the MSM community LGV, had never been studied and was based on clinical experience only. Our findings provided a scientifically proven support to the currently recommended by the U.S. Centers for Disease Control and Prevention and became standard the treatment regimens of a 21-day doxycycline regimen for LGV proctitis and a 7-day regimen for non-LGV Chlamydia proctitis.

\section{Part II. HPV infection}

The studies described in Chapters 6, 7 and 8 form Part II that broaden our knowledge on the natural history of the infection and epidemiological and diagnostic aspects of HPV infections in men in particular.

In Chapter 6 we were first to explore whether HPV is detectable in expressed prostate secretions (EPS) and whether analysis of EPS would yield any additional information compared to analysis of consecutive samples from the distal urethra. Using the multiplexed genotyping method in our study of 752 men visiting urology outpatient clinics in St. Petersburg, Russia, the HPV prevalence was found 25.9\% in the male distal 
urethra and $32.6 \%$ in the prostate secretion specimens, resulting in an overall $47.9 \%$ of HPV-positivity. We discovered that only 6.4\% had the same HPV-type in both EPS and urethral samples. Compared to analysis of urethral samples only, the analysis of EPS increased the HPV prevalence in this population with 26.2\%. Both high-risk and low-risk HPVs were detected more common in the EPS than in the urethral samples $(p=0.06$ and $p=0.0003$, respectively). We found that HPV prevalence in men decreased with increasing age, both for urethral ( $\mathrm{p}=0.009)$ and EPS ( $\mathrm{p}=0.003)$ samples. Combining urethral and EPS samples resulted in the $42.0 \%$ high-risk HPV-positivity in the studied population, almost twice as much as seen when analyzing only samples from the distal urethra. We concluded that prostate secretions represent an informative sample material for the study of HPV epidemiology in the male.

In Chapter 7 we studied the prevalence and determinants of cutaneous $\beta$ - and $\gamma$-HPVs in the anal canal of 415 men who have sex with women (MSW), using a multiplex PCR combined with Luminex technology. We found cutaneous $\beta$ - and $\gamma$-HPV types to be relatively common in the anal canal of Russian heterosexual men (24\% and 14\%, respectively). Both $\beta$ and $\gamma$ genera were significantly more likely to be detected in the anal samples of HIV+ compared to HIV- MSW (OR: 11.46, 95\%CI: 4.92-26.69 and OR: 7.80, 95\% CI: 3.57-17.02, respectively). We suggested that routes other than penile-anal intercourse may be important in cutaneous HPV transmission.

In Chapter 8 we studied the determinants of presence of mucosal $\alpha-\mathrm{HPV}$ in the anal canal of men, in which MSMs and MSWs were recruited from the same population. Anal canal swab samples from 359 Russian MSW and 31 MSM were tested for HPV using a Luminex assay.

Overall, anal $\alpha$-HPV-positivity in the studied Russian HIV-negative MSW was $15.7 \%$. Anal $\alpha$-HPV positivity was not associated with the number of lifetime sexual partners, age of participants or age at sexual debut but was more common among MSM (p<0.0001) and among HIV-positive men (OR: 3.8, 95\%CI: 1.8-8.1). We concluded that although sexual orientation and HIV status are major determinants of anal presence of HPV, anal HPV is common among Russian heterosexual men.

In Chapter 9, an overview is given to what the findings of the studies included in the thesis add to the already existing knowledge on C. trachomatis and HPV infections, and future directions for prevention, diagnostics and research are discussed. 

Samenvatting 


\section{Samenvatting}

Chlamydia trachomatis en HPV infecties zijn wereldwijd de meest voorkomende bacteriële en virale seksueel overgedragen infecties. Deze twee infecties zijn van groot volksgezondheidsbelang omdat onbehandelde Chlamydia infecties kunnen leiden tot onvruchtbaarheid en buitenbaarmoederlijke zwangerschappen terwijl persisterende HPV infecties kunnen leiden tot de ontwikkeling van baarmoederhals kanker. Beide infecties zijn ook geassocieerd met een verhoogd risico op het krijgen van een HIV infectie. Veel van deze infecties hebben een asymptomatisch beloop en blijven daardoor onopgemerkt.

Verschillende preventieve strategieën waaronder vaccinatie, screening programma's voor hoog-risico groepen, verbeterde diagnostiek, en optimale behandeling van patiënten in de kliniek, worden ingezet om de zogenaamde 'burden of disease' veroorzaakt door seksueel overgedragen infecties te verminderen. Om dit te kunnen doen is er een beter begrip nodig van de biologische achtergrond, epidemiologie en transmissie routes, alsmede goede, betrouwbare, vroege diagnostiek van het pathogeen. Helaas zijn betrouwbare getallen over de prevalentie en incidentie van Chlamydia en HPV infecties lastig te verkrijgen door het asymptomatische klinische beeld van deze infecties en door het gebrek aan betrouwbare informatie uit vele landen op de wereld. Dit gebrek aan betrouwbare informatie wordt mede veroorzaakt door verschillende manieren van pathogeen detectie en rapportage, en door problemen met stigmatisering van bepaalde hoogrisico populaties (bv. mannen die seks hebben met mannen (MSM)). Er kan meer inzicht verkregen worden in de rol van variaties in de pathogenen in relatie tot het klinisch beloop op zowel populatie niveau als op het niveau van de individu door middel van geavanceerde diagnostische middelen in state-of-the-art laboratoria. Deze diagnostische middelen kunnen ook ingezet worden om beter inzicht te krijgen in de landen waar deze middelen niet direct beschikbaar zijn.

Data over de prevalentie van urogenitale Chlamydia infecties en al haar varianten en typen in de populaties in Rusland zijn beperkt of zelfs afwezig, zeker in vergelijk tot de data die internationaal beschikbaar is. Het implementeren van een verbeterde klinische behandeling van Chlamydia LGV infecties in homoseksuele mannen in Rusland werd beter mogelijk door data die beschikbaar werd uit studies die zijn uitgevoerd in Nederland. Er is tevens nog weinig bekend over de prevalentie van HPV 
en HPV typen in de mannelijke anus en genitaliën, in het bijzonder in de niethomoseksuele mannen in zijn algemeenheid en in Rusland in het bijzonder.

Dit proefschrift behandelt deze onderwerpen in twee delen.

Hoofdstuk 1 behandelt de epidemiologie van urogenitale $C$. trachomatis en HPV infecties wereldwijd en in Rusland; geeft een overzicht van SOA zorg in Rusland en de uitdagingen in de management van SOAs en SOA onderzoek; beschrijft aspecten van preventie, diagnostiek, en klinische behandeling van infecties; en geeft een overzicht van de studies die beschreven zijn in dit proefschrift.

\section{Deel I. Chlamydia trachomatis (Ct) infecties}

Hoofdstukken 2 t/m 5 vormen samen Deel I en focussen op de epidemiologische en diagnostische aspecten die bijdragen aan een verbetering van de klinische behandeling van urogenitale $\mathrm{Ct}$ infecties.

In Hoofdstuk 2 wordt de beschikbare data uit de literatuur over de prevalentie van urogenitale Ct infecties in Russische populaties geanalyseerd. Uit een systematisch review van de literatuur kwamen 10 studies die voldeden aan de inclusie criteria. Dit review werd uitgebreid met data uit een multicenter studie, uitgevoerd op 1263 mensen uit de op één na grootste stad in Rusland, Sint-Petersburg, waarin getest werd op Chlamydia in urethrale, anale, cervix, en prostaat samples. De prevalentie van urogenitale $\mathrm{Ct}$ infecties in Russische populaties loopt uiteen van $2.9 \%$ tot $33 \%$. Deze multicenter studie verschafte inzicht in de risico factoren, waaronder het hebben van symptomen ( $p: 0.004$; bij mannen p<0.001), leeftijd jonger dan 30 jaar ( $p: 0.001$ ), en MSM; p: 0.0084). De Ct prevalentie was hoger in groepen waar urethra samples gecombineerd werden met prostaat secretie samples voor detectie. De Ct detectie met behulp van Russische tests haalde in sommige instellingen in Sint-Peterburg betrouwbaarheidsniveaus die vergelijkbaar zijn met internationale beschikbare testen. In onze studie suggereerden wij ook dat prostaat secreties mogelijk een te testen materiaal is bij de studie van Ct infecties bij mannen. Een van onze conclusies was dat de overweging gemaakt moet worden om te starten met screenen op Chlamydia infecies in hoog-risico populaties Rusland.

In Hoofdstuk 3 hebben we voor het eerst de Ct serogroep en serovar distributie bepaald in Russische mannen en vrouwen, en hebben we dit vergeleken met data uit 
Nederland populaties. De serogroep distributie in de Russische studie was vergelijkbaar met die uit Nederland en de rest van de wereld: serogroup B was het meest prevalent (46\%), gevolgd door serogroep I (33\%) and serogroep C (21\%). De distributie was vergelijkbaar tussen mannen en vrouwen. Op serovar niveau werden er kleine verschillen gevonden.

In Hoofdstuk 4 hebben we de wereldwijde diversiteit van Ct stammen, zogenaamde 'strain types' (ST) bestudeerd door 323 referentie en klinische samples uit Afrika, Amerika, Azië, en Europe te vergelijken met de Multi Locus Sequence Typing (MLST) techniek. Hierin hebben wij ook 58 samples uit Rusland meegenomen. Er zijn nog niet eerder samples uit Rusland met behulp van MLST getypeerd. Sommige STs waren sterk geassocieerd met geografische regio's (p: $0.0004-0.032$ ). Rusland had meer verschillende STs in vergelijking tot Europe en Amerika met een ST/sample ratio van 0.45 (95\% Cl: 0.32-0.53, p<0.009). Dit kan betekenen dat er meer STs uitgewisseld worden tussen regio's binnen Rusland door frequent seksueel contact, en/of een hogere mate van herverdeling van ST allelen. Van de 26 STs die gevonden zijn in Russische samples, waren er 18 (69\%) nieuw. Dit was te verwachten omdat samples uit Rusland nog niet eerder getypeerd zijn met MLST. Het hogere aantal recombinaties binnen Europe duidt op een selectie druk of adaptieve veranderingen waarvoor extra onderzoek noodzakelijk is om een beter inzicht te krijgen.

In Hoofdstuk 5 hebben we de behandeling van Chlamydia LGV en non-LGV met doxycycline geëvalueerd door anale swabs van Nederlandse mannen die seks hebben met mannen te testen voor Ct DNA en RNA persistentie. De optimale behandelduur voor proctitis veroorzaakt door Ct serovar L, die een LGV endemie veroorzaakt onder mannen die seks hebben met mannen, is nog nooit bestudeerd en was alleen gebaseerd op klinische ervaringen. Onze bevindingen hebben een wetenschappelijke basis gegeven aan de huidige richtlijn van de Amerikaanse Centers for Disease Control and Prevention. Daarmee is de huidige behandeling van 21 dagen doxycycline voor LGV proctitis en 7 dagen doxycycline voor non-LGV proctitis standaard geworden.

\section{Deel II. HPV Infecties}

De studies in hoofdstukken $6 \mathrm{t} / \mathrm{m} 8$ vormen samen deel II. Dit deel verbreedt onze kennis over de biologische kenmerken, de epidemiologie, en de diagnostiek van HPV infecties, in het bijzonder bij mannen. 
Wij zijn de eersten die geanalyseerd hebben of HPV te detecteren is in 'expressed prostate secretions' (EPS) en of het analyseren van EPS nog meer informatie zou opleveren in vergelijk tot het analyseren van meerdere samples van de distale urethra (Hoofdstuk 6). Met behulp van multiplex PCR vonden wij een HPV prevalentie van $25.9 \%$ in de distale urethra van mannen, een prevalentie van $32.6 \%$ in prostaat secretie samples, en een totale HPV prevalentie van $47.9 \%$ in een studie populatie van 752 mannen die de urologie poliklinieken bezochten in Sint-Petersburg. Slechts $6.4 \%$ had hetzelfde HPV type in zowel het EPS sample als het urethra sample. Analyse van EPS deed de HPV prevalentie in deze populatie stijgen met $26.2 \%$ in vergelijk tot het analyseren van urethra samples alleen. Zowel hoog-risico als laag-risico HPV types werden vaker gezien in EPS dan in urethra samples (P: 0.06 en 0.0003 , respectievelijk). HPV prevalentie bij mannen nam af met de leeftijd, zowel in urethra samples (p: 0.009) als in EPS samples (p: 0.003). De combinatie van EPS en urethra samples leidde tot de $42 \%$ hoog-risico HPV prevalentie in onze studie populatie. Dit is bijna twee keer zo hoog als wanneer alleen urethra samples geanalyseerd worden. Wij hebben geconstateerd dat prostaat secreties een informatief sample materiaal vormen bij het bestuderen van de epidemiologie van HPV infecties bij mannen.

In Hoofdstuk 7 hebben we de prevalentie en determinanten van $\beta$ - en $\mathrm{\gamma}$-HPV in de anus van 415 mannen die seks hebben met vrouwen bestudeerd met behulp van multiplex PCR gecombineerd met Luminex technologie. $\beta$ - en $\mathrm{Y}$-HPVs werden relatief vaak gevonden in de anus van deze Russische heteroseksuele mannen ( $24 \%$ en $14 \%$ respectievelijk). De $\beta$ en $y$ genera kwamen significant vaker voor bij HIV positieve mannen die seks hebben met vrouwen dan bij HIV negatieve mannen die seks hebben met vrouwen (respectievelijk, OR: 11.46, 95\%Cl: 4.92-26.69 en OR: $7.80,95 \% \mathrm{Cl}$ : 3.57-17.02). In dit hoofdstuk hebben wij gesuggereerd dat transmissie routes anders dan penis - anus contact van belang kunnen zijn bij HPV transmissie.

In Hoofdstuk 8 hebben we gekeken naar determinanten voor de aanwezigheid van a-HPV in de mucosa van de mannelijke anus, in mannen die seks hebben met mannen en mannen die seks hebben met vrouwen uit dezelfde populatie. Anale samples van 359 Russische mannen die seks hebben met vrouwen en 31 mannen die seks hebben met mannen zijn met behulp van de Luminex test getest op HPV. a-HPV werd gevonden in $15.7 \%$ van de Russische HIV-negatieve mannen die seks hebben met vrouwen. a-HPV positiviteit in de anus was niet geassocieerd met het aantal seksuele 
partners, de leeftijd van de deelnemers, of de leeftijd van eerste seksueel contact. Het werd wel vaker gezien bij mannen die seks hebben met mannen $(p<0.0001)$ en HIVpositieve mannen (OR: $3.8,95 \% \mathrm{Cl}$ : 1.8-8.1). Onze conclusie was dat seksuele geaardheid en HIV status belangrijke determinanten zijn voor HPV infecties in de anus, maar ook dat anale HPV veel voor komt bij Russische hetero-seksuele mannen.

Hoofdstuk 9 geeft een overzicht van wat de studies uit dit proefschrift hebben toegevoegd aan de reeds bestaande kennis over C. trachomatis en HPV infecties. Daarnaast worden toekomst perspectieven voor preventie, diagnostiek, en onderzoek bediscussieerd. 
Краткое содержание 


\section{Краткое содержание}

Во всем мире ведущими бактериальными и вирусными причинами заболеваний, передающихся половым путем, являются Chlamydia trachomatis и ВПЧ. Эти две инфекции имеют большое значение для общественного здравоохранения, поскольку непролеченный хламидиоз может приводить к бесплодию и эктопической беременности, носительство ВПЧ может приводить к развитию злокачественных новообразований, а обе инфекции также связаны с риском заражения ВИЧ. Многие заболевания, вызванные этими инфекциями, протекают бессимптомно и поэтому остаются необнаруженными.

Для снижения бремени болезней вызванных инфекциями передаваемыми половым путем (ИППП), в рамках многокомпонентной стратегии сочетаются профилактические вмешательства, в том числе программы вакцинации или скрининга предназначенные для групп риска, улучшенная диагностика и оптимальное клиническое лечение. Для этого необходимо лучшее понимание течения болезни, её эпидемиологии, а также путей передачи, оптимального раннего выявления и надёжной диагностики инфекционного агента. Однако достоверные данные о частоте заболеваемости хламидиями и ВПЧ и их распространенности сложно получить из-за природы самих патогеннных агентов или из-за отсутствия достоверной информации по ним во многих частях мира, что является следствием разнообразности систем контроля или наблюдения за группами населения высокого риска (например, в результате стигматизации мужчин, практикующих половые контакты с мужчинами, (MCM)). Лучшее понимание роли разнообразия патогенных микроорганизмов на популяционном или индивидуальном уровнях можно получить с помощью современных диагностических подходов, доступных в современных лабораторных условиях и перенесённых в те регионы мира, где отсутствуют необходимые технологии или ресурсы.

Данные о распространённости генитальной хламидийной инфекции, спектре её серологических вариантов и штаммов в российских популяционных группах оставались, по сравнению с международными, ограниченными или же просто отсутствовали. В результате исследования, проведенного в Нидерландах, стало возможным применение более оптимального клинического лечения хламидийной инфекции, вызванной LGV, в популяциях MCM. 
Остается относительно мало известно о распространённости и спектре типов ВПЧ мужской аногенитальной области, в частности среди популяционных групп, не относящихся к группам МСM.

Данная диссертация рассматрвает вышеизложенные проблемы в двух разделах.

В главе 1 представлен обзор данных по эпидемиологии генитальных инфекций, вызванных C. trachomatis и ВПЧ, во всем мире и в России; даётся обзор службам, занимающимся ИППП в России, и проблемам, связанным с лечением и научными исследованиями в области ИППП; даётся описание аспектов профилактики, диагностики и клинического лечения данных инфекций, а также краткое описание исследований, представленных в данной работе.

\section{Раздел I. Хламидийная инфекция (C. trachomatis)}

Исследования, описанные в главах 2, 3, 4 и 5, составляют Раздел I, в котором основное внимание уделяется эпидемиологическим и диагностическим аспектам, направленным на улучшение клинического лечения инфекций половых органов, вызванных C. trachomatis.

Во 2-й главе проанализированы все имеющиеся российские данные о распространённости хламидийной генитальной инфекции среди населения, полученные из всех доступных рецензируемых источников. В подготовленном систематическом обзоре литературы было выявлено 10 статей, которые соответствовали критериям включения, и который был дополнен данными, полученными в Санкт-Петербурге, втором по величине городе России, в результате многоцентрового исследования 1263 человек, обследованных на наличие хламидийной ДНК в уретре, цервикальном и анальном каналах, а также в образцах секрета предстательной железы (СПЖ). Общая распространённость хламидийной инфекции среди включенных в исследование российских популяционных групп составила от 2,9\% до 33\%. Многоцентровое исследование выявило факторы риска, которые включали в себя: наличие симптомов $(\mathrm{P}=0,004, \mathrm{y}$ мужчин: $\mathrm{P}<0,001)$, возраст моложе 30 лет $(\mathrm{P}=0,001)$, а также принадлежность к $\mathrm{MCM}(\mathrm{P}=0,0084)$. Обнаружение C. trachomatis было выше в группах, где образцы уретры были объединены с образцами СПЖ. Диагностика хламидий российскими тестсистемами в некоторых лабораториях в Санкт-Петербурге может предоставить 
уровень надёжности, сопоставимый с международным. Мы также предположили, что СПЖ может представлять дополнительный материал при отборе проб для диагностики хламидийной инфекции у мужчин. Мы пришли к выводу, что следует рассмотреть вопрос о начале программ скрининга по хламидиозу в России среди групп высокого риска.

В главе 3 мы впервые определили спектр хламидийных серогрупп и сероваров среди российской популяционной когорты женщин и мужчин и сравнили их с данными, полученными в Нидерландах. Как и в данных, полученных в Нидерландах и во всём мире, в изученной российской группе наиболее распространённой была серогруппа В (46\%), за ней следовали серогруппа I (33\%) и серогруппа C $(21 \%)$, с сопоставимым распределением среди мужчин и женщин. Однако существенные различия между изученными популяционными когортами наблюдались на уровне распределения сероваров. Так, например, по сравнению с голландскими группами, в российской группе наблюдалось значительно более высокое преобладание серовара В/Ba (5 против 1\%, P<0,0001; OR: 12,06, 95\%CI: 3,541,1). Серовар F встречался реже (8 против 23\%), а серовар G/Ga, напротив, имел более высокую (25 против 9\%) распространённость по сравнению с голландскими группами населения (P<0,0001, OR: 7,4, 95\%CI 3,8-14.5). В диагностированных как C. trachomatis-положительные в России образцах, наличие хламидийной ДНК было повторно подтверждено в Нидерландах, что может свидетельствовать о надёжности определения обнаружения хламидий в Санкт-Петербурге. Эпидемиологические исследования, проведенные на большом количестве клинических образцов и популяционных когорт с различными профилями риска по инфекциям, а также данные по распространённости различных сероваров внутри популяций могут быть использованы, среди прочего, в исследованиях передачи инфекции и для определения групп по её передачи.

В главе 4 мы проанализировали мировое разнообразие типов хламидийных штаммов (ST) путём изучения 323 референтных и клинических образцов из Африки, Америки, Азии и Европы, в том числе 58 образцов из России - региона, не представленного в исследованиях с применением высоконадёжной схемы мультилокусного секвенирования C. trachomatis (MLST). Мы обнаружили, что некоторые штаммы ST в значительной степени [p=0,0004-0,032] ассоциировались с определённым географическим регионом. На региональном уровне, со 
значительно более высоким ST/образец-коэффициентом, равным 0,45 (95\%CI: 0,35-0,53), количество штаммов ST было больше в России по сравнению с Европой или Америкой $(\mathrm{p}<0,009)$, что может отражать более высокий уровень сексуального смешивания с введением STs из других регионов и/или повторной рекомбинацией аллелей. Из 26 штаммов ST, которые содержали российские образцы хламидий, 18 (69\%) были новыми, что можно было ожидать, поскольку анализ MLST ранее не выполнялся в России. Более же высокое количество рекомбинантов в Европе указывает на избирательное давление и/или адаптивную диверсификацию, что потребует дополнительных исследований для изучения этого вопроса.

В главе 5 мы изучили микробное излечение хламидийных инфекций венерического лимфогранулематоза (LGV) и не-LGV путём тестирования на наличие ДНК и РНК C. trachomatis в соскобах из анального канала голландских МСМ, так как оптимальная продолжительность лечения проктита, вызванного хламидийным сероваром L (который вызывает эндемичный среди MCM LGV), прежде не изучалась, и продолжительность терапии основывалась только на клиническом опыте. Наши результаты предоставили научно обоснованную поддержку схемам лечения, рекомендованным Центрами США по контролю и профилактике заболеваний, и ставшим в настоящее время стандартными схемам лечения с применением доксициклина: 21 день при проктитах, вызванных LGV и 7дневный режим для не-LGV хламидийного проктита.

\section{Раздел II. Папилломавирусная (ВПЧ) инфекция}

Исследования, описанные в главах 6, 7 и 8, составляют Раздел II, который расширяет наши знания об инфекционных, эпидемиологических и диагностических аспектах инфекций вызванных ВПЧ, в особенности у мужчин.

В главе 6 мы впервые провели диагностику ВПЧ в секрете предстательной железы (СПЖ), а также изучили вопрос, позволяет ли такое исследование получить какую-нибудь дополнительную информацию по сравнению с диагностикой образцов, полученных из дистального отдела уретры. Применив в нашем исследовании метод мультиплексированного генотипирования у 752 мужчин, обратившихся амбулаторно в урологические клиники в Санкт-Петербурге, ВПЧ был обнаружен в 25,9\% образцов, полученных из дистального отдела мужской 
уретры, 32,6\% СПЖ, а в целом 47,9\% мужчин были ВПЧ-положительными. Мы обнаружили, что только 6,4\% мужчин имели тот же тип ВПЧ как в СПЖ, так и в уретральных образцах. По сравнению с анализом только уретральных образцов, диагностика СПЖ увеличила выявление частоты распространённости ВПЧ в этой популяции на 26,2\%. Типы ВПЧ высокого и низкого рисков диагностировались в образцах СПЖ чаще, чем в уретральных ( $\mathrm{p}=0,06$ и $\mathrm{p}=0,0003$, соответственно). Мы обнаружили, что распространённость ВПЧ у мужчин снижалась с возрастом, как в образцах уретры ( $\mathrm{p}=0,009)$, так и в СПЖ ( $=0,003)$. Объединение образцов из уретры и СПЖ привело к диагностике $42 \%$ мужчин в исследуемой популяции как ВПЧ-положительных, что почти в два раза больше, чем при тестировании только образцов из дистального отдела уретры. Мы пришли к выводу, что СПЖ представляет собой информативный материал образцов для изучения эпидемиологии ВПЧ у мужчин.

В главе 7 мы изучили распространённость и определяющие факторы распространённости кожных $\beta$ - и $\gamma$-ВПЧ в анальном канале у 415 мужчин, практикующих половые контакты с женщинами (МСЖ), используя многолокусную ПЦР в сочетании с технологией Luminex. Мы обнаружили, что кожные $\beta$ и $\gamma$ типы ВПЧ могут быть относительно часто диагностироваться в анальном канале у российских гетеросексуальных мужчин (24\% и $14 \%$ соответственно). Оба семейства ВПЧ, $\beta$ и $\gamma$, значительно более часто определялись в анальных образцах y ВИЧ-инфицированных, по сравнению с ВИЧ-неинфецированными MCЖ (OR: 11,46, 95\%CI: 4,92-26,69 и OR: 7,80, 95\%CI: 3,57-17,02 соответственно). Мы предположили, что другие, нежели чем пениально-анальный половой акт, пути передачи ВПЧ могут иметь важное значение для распространения кожных типов ВПЧ.

В главе 8 мы изучили основные факторы распространенности слизистых $\alpha$-ВПЧ в анальном канале мужчин, где МСМ и МСЖ были набраны из одной и той же популяции. Соскобы из анального канала, полученные у 359 МСЖ и 31 МСМ в России, были протестированы на наличие ВПЧ с использованием технологии Luminex. В целом, положительный результат теста на наличие $\alpha$-ВПЧ в анальном канале среди изученных российских ВИЧ-неинфецированных МСЖ составил 15,7\%. Положительный тест не был связан с количеством половых партнеров в течение жизни, возрастом участников или возрастом начала половой жизни, но $\alpha-$ 
ВПЧ в анальном канале чаще встречался среди МСМ (p<0,0001) и среди ВИЧинфицированных мужчин (OR: 3,8, 95\%CI: 1.8-8.1). Мы пришли к выводу, что хотя сексуальная ориентация и ВИЧ-статус являются основными детерминантами анального присутствия $\alpha$-ВПЧ, ВПЧ в анальном канале распространен также и среди гетеросексуальных мужчин.

В главе 9 дается обзор того, как результаты включённых в диссертацию исследований обогащают уже имеющиеся знания по C. trachomatis и инфекциям, вызванным ВПЧ, а также обсуждаются дальнейшие пути их профилактики и диагностики и будущие научные исследования. 



\section{Résumé}




\section{Résumé}

Dans le monde entier, les infections à Chlamydia trachomatis et aux papillomavirus humains (VPH) représentent les principales causes bactériennes et virales des infections sexuellement transmissibles. Les deux sont d'une grande importance en termes de santé publique, car une chlamydiose non traitée peut entraîner l'infertilité et une grossesse extra-utérine, un VPH persistant peut déclencher le développement d'une tumeur maligne, et les deux sont également associés au risque de contracter le VIH. De nombreuses infections sont asymptomatiques et ne sont donc pas détectées.

Pour réduire le fardeau des maladies causées par les infections sexuellement transmissibles, de multiples stratégies combinent différentes interventions de prévention, comprenant des programmes de vaccination ou de dépistage ciblant les populations à risque, des diagnostics améliorés et une gestion clinique optimisée. Ce genre de stratégies nécessite une meilleure compréhension de l'histoire naturelle, de l'épidémiologie et des voies de transmission, ainsi qu'une détection précoce optimale et un diagnostic fiable de l'agent infectieux. Cependant, des chiffres fiables sur la prévalence et l'incidence des infections à Chlamydia et aux VPH sont difficiles à obtenir en raison de la nature de l'agent pathogène ou du manque d'informations fiables provenant de nombreuses régions du monde, résultant de la variété des systèmes de surveillance et des difficultés à approcher les populations à risque (i.e., stigmatisation des les hommes qui ont des rapports sexuels avec d'autres hommes (HSH)). De meilleures connaissances sur le rôle de l'abondance des variations de l'agent pathogène à l'échelle populationnelle ou à l'échelle individuelle peuvent être obtenues grâce à des approches diagnostiques avancées disponibles dans des laboratoires de pointe et transférées dans les zones du monde dépourvues d'assistance technique ou de ressources.

Les données sur la prévalence de l'infection génitale à Chlamydia, le spectre de ses variantes sérologiques et ses types de souches dans les populations russes sont restées limités ou manquaient simplement par rapport aux données internationales disponibles. La gestion clinique améliorée du lymphogranulome vénérien (LGV) lié à l'infection à Chlamydia dans la population MSM est devenue possible à la suite de l'étude réalisée aux Pays-Bas.

Relativement peu de choses sont connues sur la prévalence et le spectre des types de VPH dans la région anogénitale masculine, en particulier chez les populations non-HSH.

Cette thèse a abordé ces sujets en deux parties. 
Le chapitre 1 décrit l'épidémiologie des infections génitales à $C$. trachomatis et aux VPH dans le monde et en Russie, donne un aperçu des services d'IST en Russie et des défis liés à la prise en charge des IST et des recherches connexes, décrit les aspects préventifs, diagnostiques et cliniques des infections et présente les grandes lignes des études décrites dans cette thèse.

\section{Partie I: Infection à Chlamydia trachomatis (Ct)}

Les études décrites dans les chapitres 2, 3, 4 et 5 constituent la partie I. Celle-ci se concentre sur les aspects épidémiologiques et diagnostiques, contribuant à l'amélioration de la prise en charge clinique des infections génitales liées à Ct.

Dans le chapitre 2, nous avons analysé toutes les données disponibles au sein d'articles publiées avec comite de révision, sur la prévalence des infections génitales liées à Ct concernant les populations russes. Une revue systématique de la littérature a permis la sélection de 10 articles répondant aux critères d'inclusion. Ces derniers ont été regroupés avec les données de l'étude multicentrique réalisée sur 1263 personnes à SaintPétersbourg (la deuxième plus grande ville de Russie) à partir d'un test ADN de Ct dans des échantillons provenant de l'urètre, de l'anus, ainsi que du col de l'utérus et de la prostate. Au sein des populations russes, la prévalence globale des infections génitales à Ct variait de 2,9\% à 33\%. L'étude multicentrique a révélé certains facteurs de risque, notamment le fait d'être symptomatique $(\mathrm{p}=0,004, \mathrm{p}<0,001)$, d'être âgé de moins de 30 ans ( $\mathrm{p}=0,001)$ et d'être un homme ayant des rapports sexuels avec d'autres hommes $(\mathrm{HSH})(\mathrm{p}=0,0084)$. La prévalence de Ct était plus élevée dans les groupes où les échantillons de l'urètre étaient regroupés avec des échantillons de sécrétion de prostate. Des tests de détection de Ct développés localement et utilisés dans certains sites de SaintPétersbourg, ont montré des niveaux de fiabilité comparables à ceux des tests disponibles au niveau international. Nous avons également suggéré que les sécrétions de la prostate pouvaient représenter un matériel d'échantillonnage supplémentaire pour l'étude de l'infection par Ct chez les hommes. Nous avons conclu que le lancement de programmes de dépistage de chlamydia ciblant les populations à haut risque en Russie devrait être envisagé.

Dans le chapitre 3, nous avons été les premiers à déterminer la distribution du sérogroupe et du sérovar $\mathrm{Ct}$ chez les femmes et les hommes russes. Au sein de cette 
population, le sérogroupe B était le plus répandu (46\%), suivi du sérogroupe I (33\%) et du sérogroupe C (21\%) avec des distributions similaires entre hommes et femmes. Ces résultats étaient comparables à ceux des Pays-Bas. Cependant, des différences significatives ont été observées entre les cohortes étudiées au niveau de la distribution du sérovar. Une prévalence significativement plus élevée du sérovar B / Ba a été observée dans les cohortes russes par rapport aux cohortes hollandaises (5 vs 1\%, P <0,0001; 12,06, IC à 95\%: 3,5-41,1). La prévalence du sérovar F avait diminuée (8 contre 23\%), alors que celle du sérovar G / Ga (25 contre 9\%) avait augmentée par rapport aux cohortes hollandaises ( $\mathrm{P}<0,0001$, OR: 7,4, IC à 95\%: 3,8-14.5). Les échantillons détectés positifs en Russie ont été confirmés positifs aux Pays-Bas, ce qui suggère la fiabilité de la détection de Ct à Saint-Pétersbourg. Les études épidémiologiques des infections à Ct, basées sur un nombre élevé d'isolats et de cohortes présentant des profils de risque différents d'infections et de propagation de différents sérovar, peuvent être utilisées pour étudier d'autres transmissions et ainsi identifier des réseaux sexuels spécifiques.

Dans le chapitre 4, nous avons analysé la diversification globale des types de souches Ct. L'étude a porté sur l'analyse de 323 échantillons cliniques et de référence provenant d'Afrique, d'Amérique, d'Asie et d'Europe, dont 58 provenant de Russie, une région qui n'était pas représentée auparavant dans les schémas de typage pour $\mathrm{Ct}$, avec un schéma Ct Multi Locus Sequence Typing (MLST) plus que valide. Nous avons trouvé que certaines souches étaient significativement associées à une région géographique particulière $[\mathrm{p}=$ 0,0004-0,032]. Le nombre de souches était plus élevé en Russie avec un ratio souches / échantillon significativement plus élevé de 0,45 (IC 95\%: 0,35-0,53) comparé à l'Europe ou l'Amérique ( $\mathrm{p}<0,009)$. Ceci pourrait refléter un niveau plus élevé de mixité sexuelle en Russie avec l'apparition de souches provenant d'autres régions et/ou de réassortiment d'allèles. Sur les 26 souches identifiées dans les échantillons russes, 18 (69\%) étaient nouvelles ; ce résultat peut s'expliquer par le fait que la population russe n'avait pas été échantillonnée pour les analyses MLST auparavant. Le nombre plus élevé de recombinants en Europe indique une pression sélective et/ou une diversification adaptative, ce qui nécessitera des études supplémentaires pour élucider ce phénomène.

Dans le chapitre 5, nous avons évalué le traitement microbien contre Chlamydia LGV et non-LGV avec un traitement à la doxycycline en testant la persistance de l'ADN et de l'ARN Ct dans des échantillons de frottis anaux provenant de HSH de nationalité hollandaise. En effet, la durée optimale de traitement de la proctite causée par le Ct de 
sérovar L, la LGV étant endémique au sein de la communauté HSH, n'avait jamais été étudiée et était basée uniquement sur l'expérience clinique. Nos résultats sont venus appuyer scientifiquement un regime de traitment à la doxycycline de 21 jours pour la proctite LGV et un de 7 jours pour la proctite de Chlamydia non LGV, recommandés par le Les Centres pour le contrôle et la prévention des maladies aux États-Unis («U.S. Centres for Disease Control and Prevention ») et considérés comme des standards.

\section{Partie II. Infection aux VPH}

Les études décrites dans les chapitres 6, 7 et 8 constituent la partie II qui élargit nos connaissances sur l'histoire naturelle de l'infection et sur les aspects épidémiologiques et diagnostiques des infections aux VPH chez les hommes en particulier.

Dans le chapitre 6, nous avons été les premiers à explorer si le VPH était détectable dans les sécrétions prostatiques exprimées (SPE) et si l'analyse des SPE fournissait des informations supplémentaires par rapport à l'analyse d'échantillons consécutifs de l'urètre distal. En utilisant la méthode de génotypage multiplexe dans notre étude de 752 hommes visitant des cliniques d'urologie ambulatoires à Saint-Pétersbourg en Russie, la prévalence du VPH était de 25,9\% dans l'urètre distal mâle et 32,6\% dans les échantillons de sécrétions prostatiques, ce qui représente une positivité aux VPH de 47,9\%. Nous avons découvert que seulement 6,4\% des patients avaient le même type de VPH dans les échantillons de SPE et urétraux. Dans cette population, l'analyse combinée des échantillons urétraux et des SPE a permis de détecter 26,2\% supplémentaire des cas d'infections aux VPH comparé à l'analyse des échantillons urétraux seule. Les VPH à haut risque ainsi qu'à faible risque ont tous été détectés plus fréquemment dans les échantillons de SPE que dans les échantillons urétraux ( $\mathrm{p}=0,06$ et $\mathrm{p}=0,0003$, respectivement). Nous avons constaté que la prévalence du VPH chez les hommes diminuait avec l'âge, à la fois pour les échantillons urétraux ( $p=0,009)$ et pour ceux de SPE $(p=0,003)$. La combinaison d'échantillons urétraux/SPE a donné lieu à une positivité du VPH à risque élevé de 42,0\% dans la population étudiée, presque le double de celle observée lors de l'analyse d'échantillons provenant uniquement de l'urètre distal. Nous avons conclu que les sécrétions prostatiques représentaient un matériel informatif important pour l'étude de l'épidémiologie du VPH chez les hommes. 
Dans le chapitre 7, nous avons étudié la prévalence et les déterminants des VPH cutanés $\beta$ et $\gamma$ dans le canal anal de 415 hommes ayant des rapports sexuels avec des femmes (HSF), en utilisant une PCR multiplexe combinée à la technologie Luminex. Nous avons trouvé que les VPH cutanés de types $\beta$ et $\gamma$ étaient relativement communs dans le canal anal des hommes hétérosexuels russes (respectivement 24\% et 14\%). Les deux genres $\beta$ et $\gamma$ étaient significativement plus susceptibles d'être détectés dans les échantillons anaux des HSF de statut VIH + comparés aux HSF de statut VIH - (OR: 11,46, IC à 95\%: 4,92-26,69 et OR: 7,80, IC à 95\%: 3,57-17,02, respectivement). Nous avons suggéré que des voies autres que le rapport pénien-anale peuvent être importantes dans la transmission cutanée du VPH.

Dans le chapitre 8, nous avons étudié les déterminants de la présence du VPH muqueux $\alpha$ dans le canal anal d'hommes HSH et HSF, recrutés dans la même population. Des échantillons d'écouvillonnage du canal anal provenant de 359 HSF russes et de 31 HSH ont été testés pour le VPH en utilisant un test Luminex. Dans l'ensemble, la positivité du VPH $\alpha$ anal chez les HSF russes séronégatifs étudiés était de 15,7\%. La positivité du VPH $\alpha$ anal n'était pas associée au nombre de partenaires sexuels, à l'âge des participants ou à l'âge du premier rapport sexuel, mais plus fréquente chez les $\mathrm{HSH}(\mathrm{p}<0,0001)$ et chez les hommes séropositifs (OR: 3,8, IC 95\%: 1.8-8.1). Nous avons conclu que même si l'orientation sexuelle et le statut VIH sont des déterminants majeurs de la présence anale du VPH, le VPH anal est commun chez les hommes hétérosexuels russes.

Dans le chapitre 9, les conclusions des études contenues dans la thèse sont mises en perspective des connaissances déjà existantes sur les infections à C. trachomatis et aux VPH. Les orientations futures de la prévention, du diagnostic et de la recherche sur ces infections sont également discutées. 
Valorisation 


\section{Valorisation}

\section{The social and economic relevance of the research results}

The main focus of the thesis are most commonly diagnosed worldwide bacterial and viral sexually transmitted infections (STI), namely Chlamydia trachomatis (Ct) and human papillomavirus (HPV). Among long term complications of $\mathrm{Ct}$ are pelvic inflammatory disease, ectopic pregnancy, infertility, and ocular and respiratory infections in newborns. Persistent infection with HPV is a necessary cause of most of cervical and anal cancers, some cancers of the vagina, vulva, penis, rectum, oropharynx, head and neck, as well as skin and genital warts. In addition, both infections can facilitate HIV transmission. Although the two STIs are major health problems, causing serious morbidity and mortality, estimates of the global prevalence and incidence of both Chlamydia and HPV infections are limited by quantity and quality of data available from the different regions of the world due to the nature of the pathogens or the lack of reliable information from many world areas, as a result of the variety of surveillance systems or approaching highrisk populations (i.e., the presence of stigma). This also applies to such country as the Russian Federation, which originally centralized around clinical dermatovenereology services model of STI control faced tremendous challenges during the last decades caused by an abrupt free-market transition in the 1990's followed by socio-political and economic changes that contributed to rocketing of the burden of STI, including HIV. In addition, the scarce funding for health care and its management resulted in limited research studies on STIs in the country.

Addressing the burden of STIs is important in efforts to achieve the health ambitions of the Sustainable Development Goals, as embodied in the global health sector strategy on STI 2016-2021 which was adopted by the 69th World Health Assembly of the World Health Organization in May 2016.

This work starts with the stocktake of all available data on the prevalence of genital Ct infections in all available peer reviewed studies for Russian populations. This analysis was additionally expanded with data from the multicenter study run in the second-largest Russian city of St. Petersburg among 1263 people whose urethral, anal, cervical, and prostate samples were tested for the presence of Ct DNA in St. Petersburg and in Amsterdam. The study (Chapter 2) revealed that the overall prevalence of genital $\mathrm{Ct}$ infections across different Russian populations may range from $2.9 \%$ to $33 \%$. The 
multicenter study specified the risk factors, which included being symptomatic (observed in particular among men), being younger than 30 years, and being a man who has sex with men (MSM). The initiation of screening programmes for Ct infections applied to high-risk populations (i.e., young people, women and men with multiple partners, MSM, commercial sex workers, drug users) in Russia was suggested to be considered. As Ct detection with Russian tests in some settings in St. Petersburg yielded levels of reliability comparable with internationally available tests, such screening programmes could rely on less costly locally manufactured tests, though if quality of sampling and testing will remain sustainable only. Currently, testing for Ct in Russia is obligated among some population groups such as pregnant women, gynaecological or venerological patients and men with urogenital symptoms. The deployment of screening programmes for Ct targeting high-risk group populations would bring additional benefits to the Russian health care system and patients. This will result in earlier detection and treatment of $\mathrm{Ct}$, reduction in transmission of other STI, including HIV, and, also, decrease in Chlamydia-related long term complications across the nation. It will further help in evaluation the real incidence of STI, antibiotic resistance, and molecular epidemiology. All of these would result in reducing the costs for the country's health care system.

The observed geographic variations in Chlamydia serovar (Chapter 3) and strain types (Chapter 4) distribution between Russia and other geographic regions, due to potential selective mixing and adaptive diversification, supports further studies that employ extended numbers of isolates among cohorts with different risk profiles for infections and with the spread of different variants of Chlamydia. This approach could result in establishment of biobanks of Ct/STI samples. Such studies will be of great value as they could help to explain differences in Ct and STI prevalence at a population level and could provide useful insight into microbiological characteristics of infection (e.g. concurrence of infection, bacterial load, and resistance patterns), molecular epidemiology and transmission which all are essential for developing prevention strategies, especially given the increasing globally number of cross-border trips, migration and expanding international sexual networks.

Importantly, current medical practice worldwide does not always facilitate discussion of sexual behaviours and MSM may face different barriers that do not experience many of heterosexual men. Among them, but not limited to, are the lack of welcoming clinical environment and adequate health insurance (e.g., no health insurance through the 
spouse's employer as same-sex marriage currently is not an option in many countries). Conducting a study presented in Chapter 5, on evaluation of the microbial cure of Chlamydia LGV and non-LGV with doxycycline treatment by testing for Ct DNA and RNA persistence in Dutch MSM anal swab specimens, is difficult or even impossible in countries where MSM are less visible, as a result of the social stigma or religious laws that strictly prohibit homosexuality. A joint approach with political, including social and economic, commitment to reduce stigma is of great relevance. From a public health perspective, stigma is important because it contributes to delays in seeking treatment, and, therefore, increased risk of STI transmission. The lack of stigma will help to better identify risk factors and detect an infectious agent. Conducting such a study in the Netherlands allowed properly to identify the risk factors (MSM and HIV-positivity), detect an infectious agent (Ct LGV vs non-LGV strains) and result in the support to develop international recommendations on extended treatment regimen for LGV (21-days) versus non-LGV (7-day) Ct proctitis.

Studies of the epidemiology of HPV infection in men are essential. Understanding HPV natural history and transmission dynamics will lead towards improvements in cancer control through optimal uses of HPV vaccines in both women and men. The thesis broadens knowledge on the natural history of mucosal and cutaneous HPV infections and evaluates epidemiological and diagnostic aspects of oncogenic and cutaneous HPVs in men in particular.

Expressed prostate secretion (EPS) samples represent additional informative and relatively easy to obtain sampling material for the studies on urogenital infections. Interestingly, Chlamydia prevalence was found higher in the groups where urethral samples were pooled with EPS samples (Chapter 2). Combining urethral and EPS samples resulted in the $42.0 \%$ high-risk HPV-positivity in the studied population the majority of which was represented by HIV-negative men who have sex with women (MSW) (Chapter 6), almost twice as much as seen when analysing only samples from the distal urethra. EPS tested alone or in a combination with urethral swabs might not provide the complete picture but undoubtedly improve our understanding of abundance of genital microbiota. Obtained findings support further studies to elucidate whether the shift in microbiome (prostate or genital) could be involved in cancerogenesis, i.e. by applying the samples obtained in men preceding the diagnosis of urogenital (prostate) and anal cancers. Contrary to the prostate tissue that requires performing the prostate biopsy, EPS is 
relatively easy (and not-expensive) to obtain at the time of routine urological examination. In addition, because of the presence of EPS in the ejaculate, the study of EPS is of particular interest in studies of the transmission of infections to the sexual partner(s).

The data on HPV prevalence in heterosexual males worldwide are scarce. The thesis broadens knowledge on the prevalence and the determinants of presence for a broad range of cutaneous $\beta, \gamma$ (Chapter 7) and mucosal $\alpha$ (Chapter 8) HPV types in the anal canal of men, in which MSM and MSW were recruited from the same population, using a Luminex technology. Knowledge on HPV epidemiology obtained in diverse male populations is essential for a better understanding of transmission to sexual partners and the role of different HPVs as co-factors in the anogenital carcinogenesis. Sexual orientation and HIV status were major determinants of anal presence for all three HPV genera but anal cutaneous and mucosal HPVs were commonly found among the studied Russian heterosexual men (24\%, 14\% and $15.7 \%$ for $\beta$-, $\gamma$ - and $\alpha$-HPVs, respectively). The routes for the transmission of HPVs into the anal canal in MSW remain unclear. Although the presence of HPV DNA may not necessarily indicate presence of infectious virus, the obtained findings posit that routes other than penile-anal intercourse may be important in HPV transmission. Also, the studied MSW population does not represent the general population but HPV is known to be associated with a variety of cancers in men, including anal cancer and a subset a subset of penile and oral cancer, which incidence has been increasing during the last decades. The gender-neutral HPV routine vaccination could be recommended to be introduced as a part of cancer prevention strategy. Such vaccination may prevent genital warts and the spread of HPV to sexual partners through the herd immunity.

The international cooperation and knowledge transfer is of great importance for public health worldwide. During the last few decades much progress has been made in the management of several STIs, including Chlamydia and HPV infections, globally. The thesis provides an insight that such progress would be impossible without the knowledge transfer provided by the leading state-of-art centres located mostly in high-income countries to low- and middle-income countries (LMICs), which results in the development and spread of technically advanced facilities in LMICs and save many human lives across the globe. 


\section{Target groups}

This work contains useful information and specific recommendations for the evaluation of the current STI control strategies with a focus on low-resource settings. In addition to new scientific knowledge such as the first overview of data on the prevalence of $\mathrm{Ct}$ in Russia, first data on Ct serotypes, serogroups and strains in Russia, evidence for the microbiological cure of Ct LGV and non-LGV proctitis, first data on the role of prostate secretion in the studies on HPV epidemiology in men, first data on the distribution of anal cutaneous $\beta$ - and $\gamma$-HPVs and data on prevalence and the determinants of the presence for mucosal and cutaneous HPVs in the anal canal in HIV-negative heterosexual men (with a potential role of auto-inoculation), this thesis provides essential information for healthcare in general and for society, both in Russia and worldwide. The ongoing transmission of Ct, HPV and other STI, including HIV transmission as a result of high risk behaviour and the weakness of existing STI control, and low performance of cancer prevention and control management, including the lack of organized cervical cancer screening and HPV vaccination programmes is a challenge which need individual, national, and global attention and commitment.

\section{Population of reproductive age}

First, the results of this thesis are of importance for the whole sexual active population in Russia and in other low- and middle-income resource settings. Individuals of reproductive age should be aware of the common occurrence of genital and anal infections, their long term complications, and potential role in HIV transmission. Moreover, they should be aware of common high risk behaviour as described in the current thesis.

\section{National policy makers}

Second, policy makers on the federal (Ministry of Health) and regional (republican, provincial and territorial ministries of health) levels are a target. The advantages and challenges in the current STI and cancer control strategies should be regularly evaluated and updated, to better design and implementation of adjusted STI and cancer control strategies. The current best practice guidelines on STI and cancer control should be applied according to the regional situation. TA joint approach with political, including social and economic, commitment is needed to reduce stigma across the nation. 


\section{Products, services and activities}

\section{The industry}

Third, the results of this thesis should be interesting for the pharmaceutical and biotechnological industry, both Russian and global players. The high prevalence of bacterial STI, including Ct, among some populations requires the introduction of effective and not costly antibiotics to the market as well as proper control on antibacterial resistance. The high prevalence of STI, including HIV, among some populations, in particular among high-risk and/or stigmatized, could pave the way for the development and introduction of point-of-care diagnostic tests. In addition to the domination on the domestic market, Russian diagnostic companies could also consider to extend their diagnostic solutions, potentially through franchise networks, onto the markets of lowincome countries. The biobanks of STI samples could be established. Global biotechnological manufacturers could apply novel technologies in the areas and on clinical specimen previously not investigated.

\section{Policy makers}

Fourth, policy makers could consider to implement revised STI control and cancer prevention strategies, which would include the educational programmes on prevention and importance of early detection of STI across the nation, lack the stigma on sexual minorities, importance of collaboration and sharing knowledge, implementation of cervical screening and HPV vaccination programmes. This should also result in improvement of case reporting and surveillance systems, obtaining reliable epidemiological data in the country on Ct, HPV and other STI, including HIV, to better control of STI.

\section{Translation and innovation}

The results of this thesis could contribute to the translation of research into process, product, and eventually more research.

\section{Process}

The current findings on Ct prevalence in Russia give an opportunity for the development and introduction of Chlamydia screening programmes among high-risk populations in the 
country. The results of this thesis inform healthcare policy makers regarding on which populations such programmes could apply and which diagnostic approaches could be used, including tests and anatomical sites to be sampled (Chapter 2).

An improved systematic and comprehensive surveillance and control system, obtained through a joint participation of all parties involved on the regional and federal levels, would be suitable to identify the real incidence of Ct and other STI infections, including HIV, potentially monitor diagnostic and treatment failures and collect data on microbiological characteristics of STI and the scale of antibacterial resistance. Improved knowledge about the distribution of these STI will move the public health agenda towards better STI and HIV prevention and treatment programmes that would result in developing and promoting educational campaigns, reducing stigma and approaching the populations of the great need across the nation. An improved subsequent control of STI will also save costs for the public health system, as it will reduce long-term complications, potentially decrease HIV transmission, and moreover decrease healthy life years lost by improving physical, psychological, and sexual health. On the global scale, understanding of reasons for global diversification of Ct strain types, obtained through collecting and sequencing Chlamydia-positive samples within screening and improved diagnostic programmes in Russia will improve knowledge on the natural history of $\mathrm{Ct}$, decipher transmission patterns of the bacterium and, potentially, treatment failure (as described in Chapter 3).

The first national data on HPV prevalence in the anal canal among a male population that included MSW and MSM of a diverse HIV status (Chapters 7 and 8) should be extended with the studies among the general population, including different anatomical sites, to obtain the national data on HPV prevalence in men and women with anal and in women with cervical intraepithelial neoplasia, as a baseline for surveillance of the vaccination program. This will help to move the public health agenda towards organized HPV-based cervical cancer screening in women and gender-neutral HPV vaccination programmes as cost-effective, priority cancer prevention strategy.

\section{Products}

The thesis proposes several product decisions that could be of great interest for clinicians, public health specialists and policy makers in Russia and worldwide.

First, the studies in the thesis stress the importance of establishment of national biobanking programmes. Clinical significance of diversity in Ct variants between Russia 
and other geographic regions, observed abundance of HPV types detected in prostate secretion and anal specimens and their role in cancerogenesis, or further studies on the microbiome will request such large and geographically diverse collection of clinical samples. Second, the thesis invites the (local) industry to (further) develop and introduce accurate and rapid molecular point-of-care tests in the world of STI, in particular Ct and HIV. Third, more accurate (than based on the detection of HPV DNA) diagnostic approaches that could allow to distinguish between new or persistent HPV infection will have great health benefits compared to the classical diagnostic approach and can be implemented not only for HPV epidemiology and transmission studies but also in cancer prevention strategies.

\section{Research}

The thesis provides research leading to answers, but also leading to more questions.

- Available data on the epidemiology of Ct and other STI, including HIV, in Russia remain limited. National reports on STI exist but the case reporting and STI surveillance system, including compulsory partner notification and tracing are needed to be improved. Little if any Ct studies have been performed among established high-risk populations (MSM, female sex workers, etc.). No studies on potentially present LGV infections among high-risk populations have been done. The diagnostics of Ct remain suboptimal in many places. More research is needed to estimate the real figures on epidemiology of Ct and other STI in Russia.

- There are some geographic variations in Chlamydia strains between different geographic areas (e.g. between Russia and Europe, Europe and Americas). More additional research is needed to elucidate potentially existing selective pressure and/or adaptive diversification in different regions worldwide and the reasons behind that.

- The access to antibiotics in Russia is regulated but self-medication practices are common due to the ongoing non-prescription access to antimicrobials and popular self-prescribing. As inadequate treatment may result in short and long term complications, more research is needed to estimate the scale of the problem.

- Data on the prevalence of genital HPV infection in Russia is geographically narrow and remain limited with the cervix. The number of national studies on the 
relationships between HPV and cancer is scarce. National studies on the relationships between HPV and anal cancer among high-risk populations are lacking. More research is needed to estimate the epidemiology of HPV in Russia, including among high-risk populations.

- Studies among sexual minorities are limited and complicated due to social stigma. Implementation research especially focused on interventions for STI prevention and point-of-care approaches to disease diagnosis, including qualitative research on issues such as stigma, is needed.

- There is no organized HPV vaccination programme in Russia. To launch educational campaigns for successful HPV vaccination programmes, research on how the population and professionals in the country would accept HPV vaccines would be recommended.

- Many microorganisms are continuously threatening to infect the human urogenital tract (including prostate) and (also) anal canal, but their virulence is balanced by host-protective mechanisms. The further molecular and genomic studies are needed to elucidate whether transmitted STI or harbouring (non-)viral infections are involved in genital and anal carcinogenesis in both men and women, to analyse the potential protective and causative role of microbiome.

- The presence of HPV DNA does not necessarily indicate the presence of infectious virus. It is also important to study whether HPVs detected in the anal canal in MSW by PCR-based technology are viable and have clinical consequences. Further studies might also explain transmission of HPV types among men and to their (sexual) partners, the tissue tropism and role of cutaneous HPVs in anal disorders.

- Ongoing modelling and cost-effectiveness studies relevant to STI are narrow geographically but lacking in Russia. To better addressing STI prevention and treatment interventions, further studies should focus on these aspects.

These key points above should be focus of further research, with the potential to provide clinical practice and public health specialists and policy makers with relevant data on the two most common bacterial and viral STI worldwide, to give further guidance towards better STI control and cancer prevention strategies. 
Dankwoord 


\section{Dankwoord}

First of all, I would like to thank all patients, who believed in my research and in me personally, trusted me as a medical doctor and who shared with me their time and efforts to make this research come through, regardless of all obstacles and difficulties. Indeed, the research is for the patients' benefits at the end of the day but there is no research without the ones who are in need and their will to move forward the research agenda. I hope that results of these studies will be helpful for many of those who still need it worldwide.

Second, I would like to thank greatly each and every of my colleagues from different parts of the world for their energy, openness, discussions, knowledge shared, help provided and being ready to help at all requests, constant support, and believe in me and all ideas that resulted in this dissertation. Without you, this research would not be possible as well.

In particular, I would like to thank very much my project team: Prof. dr. Servaas .A. Morré, Prof. dr. Henry .J.C. de Vries and Dr. Sander Ouburg.

Beste Servaas, since our first meeting in 2004 at the first Amsterdam Chlamydia meeting, you remain to me a great example of a real researcher, who is talented and kindhearted, a hard worker and a gentleman, always has time for a critical scientific discussion and also makes life look better thanks to your fantastic sense of humor. It was not only very educational but also a great pleasure to work with you. Thank you for your friendship, for being creative and open-minded, replying my mails in the very late evenings when we applied for grants or submitted manuscripts, and providing me with your advices and help.

Dear Henry, since our first meeting in 2006 at the old building of GGD Amsterdam, you remain to me a great example of a clinician with scientific curiosity, sharp look at the problems and ability to think out of the box. Discussions with you about science and life helped me a lot in establishing the research projects and my career paths Thank you for your friendship, hosting me under your roof during my visits to Amsterdam, for your sense of humor and for your impact in my better understanding both medical career and journey of life.

Dear Sander, thank you for being calmingly always next at the difficult times. For being so knowledgeable, sincere, reliable, attentive, helpful and diplomatic. Also, thank you for all those historical stories about Amsterdam and your linguistic help over years. 
Great thank you to all co-authors for the contributions they have made at work in this dissertation.

Dank aan alle leden van de beoordelingscommissie, Prof. dr. C.J.P.A. Hoebe, Prof. dr. J. van Bergen, Prof. dr. J.F.C. Glatz, Dr. D.A.M. Heideman, en Prof. dr. P. Savelkoul, voor de tijd die jullie genomen hebben voor het lezen en beoordelen van mijn proefschrift.

I am very much grateful to all my long- and short-term colleagues I was happy to work with at (listed geographically/chronologically) the VU University Medical Center, GGD Amsterdam and Maastricht University (the Netherlands), St. Petersburg State University, D.0. Ott Research Institute of Obstetrics and Gynaecology, Mikrobiomed, ImmunoBioServis and Apollon clinics, Family Planning Center in Pushkin, Medical Academy of Postgraduate Studies and North-Western State Medical University named after I.I. Mechnikov (Russia), Karolinska Institutet (Sweden), and WHO/IARC (France).

My great thankfulness is to the chiefs of my departments in St. Petersburg (Russia), who, being urologists, bravely supported my research in still-to-be-explored areas between urology and STI, in particular Prof. Andrey Gorelov (St. Petersburg State University), Prof. Andrey Novikov (Medical Academy of Postgraduate Studies) and Prof. Boris Komyakov (North-Western State Medical University named after I.I. Mechnikov).

I would also like to praise my chief in the Karolinska Institutet, Prof. Joakim Dillner, whose scientific expertise, knowledge of epidemiology and professional advises, as well as his honesty, humanism and diplomacy made a great impact on my career.

As a clinician who developed lab skills working in the labs, I cannot miss to mention lab technicians, the ones who often do most of the hardest part of the work. I would like greatly to thank my lab teachers: Jolijne Plejster (VUmc, Amsterdam), in particular for her reliability, keeping in great order all clinical samples and related data, and all fun we had at the time of Chlamydia studies; Carina Eklund (Karolinska, Stockholm), for her sincere and sharp look through the results of my experiments and all discussions, great expertise and wonderful skills for teaching; Dr. Tarik Gheit (IARC, Lyon) for introducing to his great HPV diagnostic test and Sandrine McKay-Chopin (IARC, Lyon) for her patience and comfortable work in the lab.

I am great to have both you, Anna Kouznetsova and Luc Garcia, as my paranimfen. Your help and presence in my life over the years is invaluable. Thank you for being with me.

I would also like to mention those people I have had inspiring discussions during this research period and thank them for sharing their thoughts about the projects I was 
working on and beyond. This (chronologically made) list includes but not limited with Prof. Jack Schalken and Prof. Chris Meijer (the Netherlands), Prof. Truls E. Bjerklund Johansen (Norway), Prof. Kurt Naber (Germany), Prof. Deborah Dean and Prof. Joel Palefsky (USA), Dr. Rengaswamy Sankaranarayanan, Dr. Rolando Herrero and Dr. Maribel Almonte (France), and Dr. Marilys Corbex (Denmark).

My friends, who were supportive and close by regardless of the distance. Kenneth McRooy, a wise person with a kind heart, thank you for being a great friend and supporter, and for doing your best to make me fall in love with Amsterdam. Andrey Baklushin (Mr. Reminder!), спасибо за все то кофе, что было выпито и за готовность выслушать и дать толковые советы. А также за все те напоминания о том, что диссертацию надо закончить, которые ты обещал не напоминать. Wolfgang Runkel, thank you for being a dear friend for many years, for constantly believed in my success whenever through years and for being able to find time to discuss it between your hundreds of yearly travels, this I will never forget. Sander Ouburg, thank you for translating Summary into Dutch. Our IARC's master students Semi Zouiouich, Laura Downham, my dear friend Patricia Villain and especially my dearest Luc Garcia, I know that French is not an easy language but now I know it for sure, thank you for Résumé fransais. Anastasia Dolya, thank you for your corrections with Краткое содержание. Karima Abdedayem, than you for your smiles while making PDFs in the last minute notice. Sebastien Chevalier (our wiki-Seb), I am not sure if I expressed enough my thanks for your presence and help at my first days in Lyon, your lab knowledge and expertise and for all those discussions full of fun at lunches. Isabelle Rondy, thank you for being a dear friend and I will never forget our performance in Manduria. Mauri Hekkilä, kiitos for your friendship and help. Elena Verbitskaya, thank you for your friendship and numbers of picking me up at the airport Pulkovo. Dr. Natalia Motovilova (for your administrative support and understanding), Dr. Narine Selimyan, Dr. Inna Yurkova, Dr. Maya Tchkhartishvili (for friendship and collaboration), Dr. Andrey Esipov and Dr. Anna Dotcenko (for the helping with collecting data), Dr. Olga Sokolova (for great impact at the start of studies), Mr. Anatoly Novikov (for administrative support) and Dr. Lyudmila Novikova (for encourage), Mr. Oleg Pirogov (for help with files at the start of studies), Dr. Kira Shalepo for discussions on Chlamydia diagnostics), Prof. Alevtina Savicheva (for administrative support), Dr. Elena Shipitzyna (for you lab work), Mrs. Lyudmila Azarova (for being a great welcome of our patients and for your patience and 
diplomacy), Mrs. Elena Artyukhina (for your wonderful memory on dates of patients' visits), Mrs. Luba Kuklina (for collecting the data), thank you all.

I would greatly thank my family.

Mum, thank you for your believe in me from the very first look at that day when you look at me and saw in me a medical doctor in the future. Thank you for that enormous and continuous support through the years of my studies in the extremely difficult 1990's and the years of my research studies, thank you for your constant love. You kept your interest in my studies, your curiosity and greatly supported them. Thanks a lot for all those travels you have made.

My dearest sister Natasha, you were always with me in my most difficult days which is unforgettable and for what I am very much thankful. I will not forget that all that help on the routine base neither when you spent your vacation helping me at the VUmc, to help to move studies forward. Thank to my dad and my brother Alexey for their Olympic patience and long lasting support. Mark, my son, thanks for being in my life and for all your help.

Once again, I would like to thank all listed and the ones I may have unintentionally missed, each and every, for their presence in my life. Thank you for everything you have made with me and for me. Together we are able to keep moving everything forward! 



\section{List of publications}




\section{List of publications}

\section{Peer-reviewed papers in scientific journals}

SMELOV V, VRBANAC A, VAN ESS EF, NOZ M, WAN R, EKLUND C, MORGAN T, SHRIER LA, SANDERS B, DILLNER J, DE VRIES HJC, MORRE SA, DEAN D. Chlamydia trachomatis strain types have diversified regionally and globally with evidence for recombination across geographic divides.

Frontiers in Microbiology, in press.

SMELOV V, THOMAS P, HANISCH R, OUBURG S, MORRÉ SA. Prevalence of genital Chlamydia trachomatis infections in Russia: systematic literature review and multicenter study.

Pathogens and Disease 201775 (7).

SMELOV V, HANISCH R, MCKAY-CHOPIN S, SOKOLOVA O, EKLUND C, KOMYAKOV B, GHEIT T, TOMMASINO M. Prevalence of cutaneous beta and gamma human papillomaviruses in the anal canal of men who have sex with women. Papillomavirus Research 2017 3; 66-72.

SMELOV V, BZHALAVA D, ARROYO MUHR LS, EKLUND C, KOMYAKOV B, GORELOV A, DILLNER J, HULTIN E. Detection of DNA viruses in prostate cancer.

Scientific Reports 2016 6; 25235.

SMELOV V, GHEIT T, SUNDSTROM K, PLONER A, MCKAY-CHOPIN S, EKLUND C, TOMMASINO M, DILLNER J. Lack of Significant Effects of Chlamydia trachomatis Infection on Cervical Adenocarcinoma Risk: Nested Case-Control Study. PLoS One 2016 11;5 e0156215

SMELOV V, NABER K, BJERKLUND JOHANSEN TE. Improved classification of urinary tract infection: future considerations.

European Urology Supplements 2016 15. 71-80. 
SMELOV V, NABER K, BJERKLUND JOHANSEN TE. Letter to the Editor: Diagnostic Criteria in Urological Diseases do not Always Match with Findings by Extended Culture Techniques and Metagenomic Sequencing of 16S rDNA.

The Open Microbiology Journal 2016 10; 23-6.

DONA MG, GHEIT T, LATINI A, BENEVOLO M, TORRES M, SMELOV V, MCKAYCHOPIN S, GIGLIO A, CRISTAUDO A, ZACCARELLI M, TOMMASINO M, GIULIANI M. Alpha, beta and gamma Human Papillomaviruses in the anal canal of HIV-infected and uninfected men who have sex with men. Journal of Infection 2015 71;1 74-84.

ELFSTRÖM KM, SMELOV V, JOHANSSON AL, EKLUND C, NAUCLER P, ARNHEIMDAHLSTRÖM L, DILLNER J.J. Long-term HPV type-specific risks for ASCUS and LSIL: a 14-year follow-up of a randomized primary HPV screening trial.

International Journal of Cancer 2015 136;2 350-9.

SMELOV V, ELFSTROM KM, JOHANSSON AL, EKLUND C, NAUCLER P, ARNHEIMDAHLSTROM L, DILLNER J. Long-term HPV type-specific risks of high-grade cervical intraepithelial lesions: a 14-year follow-up of a randomized primary HPV screening trial. International Journal of Cancer 2015 136;5 1171-80.

ELFSTROM KM, SMELOV V, JOHANSSON AL, EKLUND C, NAUCLER P, ARNHEIMDAHLSTROM L, DILLNER J. Long term duration of protective effect for HPV negative women: follow-up of primary HPV screening randomised controlled trial. BMJ 2014 348; g130.

SMELOV V, ARROYO MUHR LS, BZHALAVA D, BROWN LJ, KOMYAKOV B, DILLNER J. Metagenomic sequencing of expressed prostate secretions. Journal of Medical Virology 2014 86;12 2042-8.

SMELOV V, EKLUND C, ARROYO MUHR LS, HULTIN E, DILLNER J. Are human papillomavirus DNA prevalences providing high-flying estimates of infection? An international survey of HPV detection on environmental surfaces. Sexually Transmitted Infections 2013 89;8 627. 
SMELOV V, EKLUND C, BZHALAVA D, NOVIKOV A, DILLNER J. Expressed prostate secretions in the study of human papillomavirus epidemiology in the male. PLOS ONE 2013 8;6 e66630.

SMELOV V, NOVIKOV A, BROWN LJ, EKLUND C, STROKOVA L, OUBURG S, MORRE SA, DILLNER J. False-positive prostate cancer markers in a man with symptomatic urethral Chlamydia trachomatis infection. International Journal of STD \& AIDS 2013 24;6 501-2.

ARROYO LS, SMELOV V, BZHALAVA D, EKLUND C, HULTIN E, DILLNER J. Next generation sequencing for human papillomavirus genotyping. Journal of Clinical Virology 2013 58;2 437-42.

QUINT KD, GERAETS DT, VAN DEN MUNCKHOF HAM, DE KONING MNC, SMELOV V, MELCHERS WJG, DE VRIES HJC, MORRE SA, MEIJER CJM, VAN ALEWIJK DCJG, VAN DOORN LJ, QUINT WGV. Evaluation of a Novel Chlamydia trachomatis Microsphere Suspension Assay for Detection and Genotyping of the Different Serovars in Clinical Samples.

Journal of Molecular Diagnostics 2011 13;2 152-159.

SMELOV V, VAN MOORSELAAR J, STARTSEV V, SMELOVA N, GRIGOROVICH E, MEIJER C, MORRE S. No high-risk human papillomavirus infection in prostate cancer tissues. Scandinavian Journal of Infectious Diseases 2011 43;5 399-400.

DE VRIES HJC, SMELOV V, OUBURG S, PLEIJSTER J, GESKUS RB, SPEKSNIJDER AGCL, FENNEMA JSA, MORRE SA. Anal Lymphogranuloma Venereum Infection Screening With IgA Anti-Chlamydia trachomatis-Specific Major Outer Membrane Protein Serology. Sexually Transmitted Diseases 2010 37;12 789-795.

SMELOV V, QUINT KD, PLEIJSTER J, SAVELKOUL PHM, SHALEPO K, SHIPITSYNA E, DOMEIKA M, GORELOV A, SAVICHEVA A, QUINT WGV, DE VRIES HJC, OUBURG S, 
MORRE SA. Chlamydia trachomatis serovar distributions in Russian men and women: a comparison with Dutch serovar distributions.

Drugs of Today (Barc.) 2009 45; 33-38.

DE VRIES HJ, SMELOV V, MIDDELBURG JG, PLEIJSTER J, SPEKSNIJDER AG, MORRE SA. Delayed microbial cure of lymphogranuloma venereum proctitis with doxycycline treatment.

Clinical Infectious Diseases 2009 48;5 e53-6.

SMELOV V, MORRE SA, DE VRIES H. Are serological chlamydia-specific markers useful to detect asymptomatic cases of lymphogranuloma venereum proctitis? Sexually Transmitted Infections 2007 84;1 77-77.

CATSBURG A, VAN DOMMELEN L, SMELOV V, DE VRIES HJC, SAVITCHEVA A, DOMEIKA M, HERRMANN B, OUBURG S, HOEBE CJPA, NILSSON A, SAVELKOUL PHM, MORRE SA. TaqMan assay for Swedish Chlamydia trachomatis variant. Emerging Infectious Diseases 2007 13;9 1432-1434.

SMELOV V, PEREKALINA T, ARTEMENKO N, SMELOVA N, UKLEEVA G, GORELOV A. Chlamydia trachomatis survival in the presence of two fluoroquinolones (lomefloxacin versus levofloxacin) in patients with chronic prostatitis syndrome.

Andrologia 2005 37;2-3 61-64.

SMELOV V, PEREKALINA T, GORELOV A, SMELOVA N, ARTEMENKO N, NORMAN L. In vitro activity of fluoroquinolones, azithromycin and doxycycline against chlamydia trachomatis cultured from men with chronic lower urinary tract symptoms. European Urology 2004 46;5 647-650.

SMELOV V, KRYLOVA T, SMELOVA N, NORMAN L. Azithromycin treatment follow-up: antibacterial susceptibility of Chlamydia trachomatis in patients with chronic prostatitis. International Journal of Antimicrobial Agents 2004 23; S79-S82. 
SMELOV V, GORELOV A, SMELOVA N, KRYLOVA T. Single-drug or combined

antibacterial therapy in the treatment of patients with chronic prostatitis and Chlamydia trachomatis?

International Journal of Antimicrobial Agents 2004 23; S83-S87.

\section{Books chapters}

V. SMELOV. The role of chronic prostatitis in male infertility: is there a relationship? In: CAI T, NABER K, BJERKLUND JOHANSEN TE (EDS): Prostatitis and Its Management: Concepts and Recommendations for Clinical Practice. Springer 2016. 


\section{About the author}

\section{Curriculum Vitae}

Vitaly Smelov was born on 2nd September 1970 in Neustrelitz (Germany). In 1993 he was graduated from the Military Medical Academy in St. Petersburg and completed his clinical training in Urology. During the period of working as an urologist in several settings in St. Petersburg (Russia) he developed a strong scientific interest in the "grey area" between urological disorders and sexually transmitted infections. His interest in the Made in Holland research on Chlamydia and HPV infections is rooting from the times of his awarded studies located in the Netherlands, i.e., European Association of Urology's Scholarship (University of Nijmegen, 2002-2004) and Clinical Fellowship (VU University Medical Center, Amsterdam, 2007), and the UNESCO-American Society for Microbiology Travel Award (VU University Medical Center and Amsterdam GGD, 2006). Later, he continued with the research projects being awarded by the Swedish Cancer Foundation (Karolinska Institutet, Stockholm) and the International Agency for Research on Cancer (World Health Organization, Lyon, France) in collaboration with Dutch and international scientists. Vitaly Smelov is currently a Visiting Scientist in the WHO/International Agency for Research on Cancer (Lyon) and Karolinska Institutet (Stockholm), a lecturer in the North-Western State Medical University named after I.I. Mechnikov and a researcher in Petrov Oncology Research Institute (St. Petersburg). After competition of his thesis he will focus on the public health issues related to the malignant diseases in low- and middleincome countries. He lives in Lyon and St. Petersburg. 
Notes 